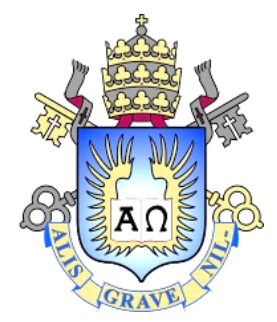

Elise Helene Moutinho Bernardo de Moraes

\title{
FOTOGRAFAR E DOCUMENTAR NA EDUCAÇÃO INFANTIL: um jogo de luzes e sombras
}

Tese apresentada como requisito parcial para obtenção do grau de Doutora em Educação pelo Programa de Pós-graduação em Educação, do Departamento de Educação da PUC-Rio.

Orientadora: Prof. ${ }^{a}$ Dr. ${ }^{a}$ Rosália Maria Duarte Coorientadora: Prof. ${ }^{\text {a }}$ Dr. ${ }^{a}$ Maria Cristina Cristo Parente 


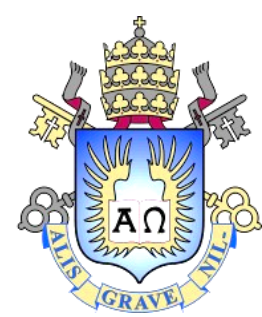

Elise Helene Moutinho Bernardo de Moraes

\title{
FOTOGRAFAR E DOCUMENTAR NA EDUCAÇÃO INFANTIL: um jogo de luzes e sombras
}

Tese apresentada como requisito parcial para obtenção do grau de Doutor pelo Programa de Pós-graduação em Educação do Departamento de Educação do Centro de Teologia e Ciências Humanas da PUC-Rio. Aprovada pela Comissão Examinadora abaixo assinada.

\author{
Prof. a Rosália Maria Duarte \\ Orientadora \\ PUC-Rio \\ Prof. - Maria Cristina Cristo Parente \\ Coorientadora \\ Universidade do Minho \\ Prof. ${ }^{a}$ Maria Cristina Monteiro Pereira Carvalho \\ PUC-Rio \\ Prof. a Zena Winona Eisenberg \\ PUC-Rio \\ Prof. Paulo Sérgio Fochi \\ Unisinos \\ Prof." Vera Maria Ramos de Vasconcellos \\ UERJ \\ Prof ${ }^{a}$ Monah Winograd \\ Coordenadora Setorial do Centro \\ de Teologia e Ciências Humanas \\ PUC-Rio
}

Rio de Janeiro, 26 de fevereiro de 2021. 
Todos os direitos reservados. A reprodução, total ou parcial do trabalho, é proibida sem a autorização da universidade, da autora e da orientadora.

\section{Elise Helene Moutinho Bernardo de Moraes}

Mestre em Educação, pela UFFS/Chapecó-SC (2015). Especialista em Processos Pedagógicos na Educação Básica, pela UFFS/Erechim-RS (2013). Licenciada em Pedagogia, pela Universidade da Cidade de São Paulo (2017) e em Letras, pela URI/Erechim-RS (2010). Possui experiência de docência na educação básica (educação infantil e ensino fundamental) e no ensino superior (Curso de Pedagogia, UFFS/Chapecó). Integra o Grupo de Pesquisa em Educação e Mídias - GRUPEM, desde 2017. Produção acadêmica com foco em: educação e contemporaneidade; infância(s); educação infantil; avaliação na educação infantil; documentação pedagógica; educação e mídias; fotografia pedagógica.

Ficha Catalográfica

Moraes, Elise Helene Moutinho Bernardo de

Fotografar e documentar na educação infantil : um jogo de luzes e sombras / Elise Helene Moutinho Bernardo de Moraes ; orientadora: Rosália Maria Duarte ; coorientadora: Maria Cristina Cristo Parente. 2021.

218 f. : il. color. ; $30 \mathrm{~cm}$

Tese (doutorado)-Pontifícia Universidade Católica do Rio de Janeiro, Departamento de Educação, 2021.

Inclui bibliografia

1. Educação - Teses. 2. Educação infantil 3. Formação de professores. 4. Pesquisa-ação. 5. Documentação. 6. Fotografia. I. Duarte, Rosália Maria. II. Parente, Maria Cristina Cristo. III. Pontifícia Universidade Católica do Rio de Janeiro. Departamento de Educação. IV. Título. 
À criança que fui um dia (que ainda pulsa em mim). 


\section{Agradecimentos}

Todos sabem que a pesquisa é um caminho solitário, mas quem imaginaria fazer uma tese atravessando tempos pandêmicos, em que o mundo todo é forçado a se isolar? Descobri, nesse percurso, que o isolamento também seria abrigo para alma, um mecanismo psicológico de preservação dos vínculos sociais verdadeiros. Assim, percebo que o doutorado não foi um tempo de solidão. Construí importantes elos afetivos, reforcei outros e contei com o suporte de muitos, em especial, daqueles que caminharam ao meu lado. A estes devo meu agradecimento...

Ao CNPq, pelos auxílios concedidos, sem os quais este trabalho não poderia ter sido realizado; e à CAPES, pela concessão de bolsa de doutorado sanduíche no exterior, no âmbito do Projeto Capes Print - O presente trabalho foi realizado com apoio da Coordenação de Aperfeiçoamento de Pessoal de Nível Superior - Brasil (CAPES) - Código de Financiamento 001.

À PUC-Rio e ao Programa de Pós-Graduação em Educação, por ter oferecido estrutura material e imaterial de excelência, que tornou possível viver a tão sonhada imersão na universidade durante o doutorado.

À Universidade do Minho, em especial ao Doutoramento em Estudos da Criança e ao Centro de Investigação em Estudos da Criança - CIEC, onde encontrei importantes contribuições teóricas à pesquisa. Agradeço, também, o suporte dado aos pesquisadores no período de confinamento provocado pela pandemia.

À professora Rosália Duarte, minha orientadora, com quem aprendi que a construção da tese poderia ser um processo leve e prazeroso. Agradeço, especialmente, pela sabedoria em equilibrar, na dose certa, orientação e liberdade, o que me permitiu fazer escolhas importantes na pesquisa.

À professora Cristina Parente, minha coorientadora, que me acolheu de forma tão afetuosa em Braga. Nas suas palavras, "há sítios de se sentir". E assim foi, vivi e senti a experiência em Portugal com toda intensidade. 
À professora Cristina Carvalho, pela sensibilidade e acolhimento na condução de minha experimentação na docência no ensino superior, como orientadora do estágio no Curso de Pedagogia da PUC-Rio. Aprendo a ser uma professora melhor, espelhando-me no seu exemplo.

Aos demais professores que compõem a banca examinadora, pelas contribuições à tese e pelo rico diálogo estabelecido: Zena Eisenberg, Paulo Fochi e Vera Vasconcellos; e às suplentes: Andréa Rivero e Silvia Brilhante.

Às pesquisadoras do GRUPEM, pelas contribuições dadas nas longas discussões, em cada passo da pesquisa.

Aos amigos queridos da turma de doutorado: Adriena, Adrian, Aldenira, Isabel, Ivo, Liliane, Luisa, Maria Paula, Sirlene e Vitoi - pessoas tão diferentes, de vários cantos do Brasil, que se despiram das vaidades acadêmicas e fizeram questão do encontro, do apoio e de vibrar com as conquistas uns dos outros.

À SMED/Erechim e à EMEI Dom João A. Hoffman, por terem aberto as portas para a pesquisa. Um agradecimento especial às professoras: Andressa, Franciane, Tchéssika e Inajara, pela generosidade de compartilhar suas vivências no trabalho com a educação infantil; e às crianças da escola que, sem dúvida, são as verdadeiras protagonistas desta pesquisa.

Aos amigos de sempre e aos que chegaram há pouco, agradeço pelos laços de afeto e cumplicidade que me constituem e me mantêm.

Ao Matheus, por ter entrado na minha vida durante esse percurso e ter tido real interesse em me conhecer, embarcar nos meus sonhos e construir outros tantos comigo.

Por fim, agradeço minha família: meus pais, Pedro e Tereza, tia Eliza e meu irmão, Pedrinho. Obrigada por respeitarem minhas escolhas, por me permitirem voar e por me acolherem com tanto amor, sempre que retorno ao ninho. 


\section{Resumo}

Moraes, Elise Helene Moutinho Bernardo de; Duarte, Rosália Maria; (Orientadora); Parente, Maria Cristina Cristo; (Coorientadora). - Fotografar e documentar na educação infantil: um jogo de luzes e sombras. Rio de Janeiro, 2021. 218 p. Tese de Doutorado - Departamento de Educação, Pontifícia Universidade Católica do Rio de Janeiro.

Esta tese tem como objeto de estudo a linguagem fotográfica no processo de documentar e narrar as vivências e aprendizagens das crianças na educação infantil. A pesquisa pretendia, sobretudo, compreender e analisar a produção de registros e documentação com fotografia em uma escola de educação infantil da rede municipal de ensino da cidade de Erechim, localizada ao norte do estado do Rio Grande do Sul. O aporte teórico está ancorado, principalmente, nas contribuições da abordagem pedagógica desenvolvida na cidade italiana de Reggio Emilia, que dá centralidade à documentação pedagógica, tendo como foco a criança, seus processos, linguagens, pensamentos e modos de ser. A imersão no campo de pesquisa se deu por, aproximadamente, oito meses - entre 2018 e 2019 - e foi realizada com atividades concomitantes: observação participativa - em espaços de uso coletivo da escola e com o acompanhamento de quatro grupos, com crianças de 4-5 anos; e diálogos transversais - entrevistas com as educadoras e participação em reuniões pedagógicas de formação no contexto. O foco investigativo da imersão na escola foi orientado pelas seguintes questões: A que processos se escolhe dar visibilidade pela fotografia? Quem é responsável por fotografar? Que criança se quer comunicar com as fotos? Como e quando se fotografa no contexto educativo? $\mathrm{O}$ que (e a quem) se pretende comunicar com as fotografias? Inicialmente, a pesquisa teve caráter exploratório e, progressivamente, assumiu contorno participante, tendo sido delimitada como pesquisa-ação. Os dados construídos com a imersão no campo foram de natureza diversa - notas de campo, gravações de áudio e fotografias produzidas pela pesquisadora. $\mathrm{O}$ tratamento dos dados se deu a partir de análise de conteúdo, realizada com apoio do software ATLAS.ti, constituindo-se duas categorias mais amplas - "Luzes e Sombras" - que elucidam a que processos dava visibilidade, mas também o que era "invisibilizado" em relação ao modo de fotografar e publicizar as fotografias. As fotografias produzidas pela pesquisadora receberam um tratamento analítico complementar à análise de 
conteúdo, que partiu de uma experiência estética/criativa de criação de um "atlas"

- na perspectiva de Didi-Huberman, como forma visual de organizar e dar sentido às imagens. Parte destas fotografias foram narradas a partir de mini-histórias, uma proposta sensível de compreender o ponto de vista das crianças sobre suas aprendizagens e investigações. A pesquisa evidencia que existem padrões e consensos em relação ao que deve ser fotografado ou exposto pelas imagens, mas também o que não deve ser mostrado. A linguagem fotográfica se reafirma como instrumento propositivo para educadores, crianças, famílias e comunidade partilharem os processos vivenciados, contribuindo para prática reflexiva de educadores e para a visibilidade das infâncias.

\section{Palavras-chave}

Educação Infantil; Formação de Professores; Pesquisa-ação; Documentação; Fotografia. 


\section{Abstract}

Moraes, Elise Helene Moutinho Bernardo de; Duarte, Rosália Maria. (Orientadora); Parente, Maria Cristina Cristo; (Coorientadora) Photographing and documenting in early childhood education: a play of light and shadow. Rio de Janeiro, 2021. 218 p. Tese de Doutorado Departamento de Educação, Pontifícia Universidade Católica do Rio de Janeiro.

This thesis has as the object of study the photographic language in the process of documenting and narrating the experiences and learning of children in early childhood education. The research aimed to understand and analyze the production of records and documentation with photography in a public preschool in the city of Erechim, located in the north of the state of Rio Grande do Sul/Brazil. The theoretical contribution is anchored mainly in the contributions of the pedagogical approach developed in the Italian city of Reggio Emilia, which gives a central role to the pedagogical documentation, focusing on the child, its processes, languages, thoughts, and ways of being. The immersion in the research field took place for approximately eight months - between 2018 and 2019 - and was carried out through concomitant activities: participatory observation - in collective spaces of the school and with the accompaniment of four groups to children aged 4-5; and interactive dialogues - interviews with educators and participation in educator meetings in the context. The investigative focus of immersion in the school was guided by the following questions: What processes the photography makes visible? Who is responsible for shooting? What child does photography communicate? How and when the photos are shot? What do educators want to communicate with the photos? Initially, the research had an exploratory character and progressively assumed a participant character, defined as a research-action. The data constructed with the immersion in the school were of a different nature - field notes, audio recordings and photographs taken by the researcher. The treatment of the data was based on analysis of content, with the support of the ATLAS.ti software, constituting two broader categories - "Lights and Shadows" - which clarify the processes gave visibility, but also what was "invisible" the way of shooting and publicizing the photographs. The photographs produced by the researcher received an analytical treatment complementary to the analysis of content, which started from an aesthetic/creative experience of creating an "atlas" - in the perspective of 
Didi-Huberman, as a visual way of organizing and giving meaning to the images. Part of these photographs were narrated from "ministories" - a sensitive proposal to understand the children's point of view about their learning built and investigations. The research shows that there is consensus in what should be photographed or exposed by the images, and what should not be shown. The photographic language asserts itself as a propositional tool for educators, children, families, and the community to share the processes experienced, contributing to the reflective practice of educators and to the visibility of childhoods.

\section{Keywords}

Early Childhood Education; Teacher training; Research-action; Documentation; Photography. 


\section{Sumário}

1 Introdução 19

1.1 Abertura da lente conceitual 22

$\begin{array}{ll}\text { PARTE I - DESCREVER } & 27\end{array}$

2 Observação, registros e documentação: em busca de uma (re)definição conceitual $\quad 29$

2.1 Abordagem pedagógica de Reggio Emilia 32

2.2 Dimensão estética na proposta de Reggio Emilia 36

2.3 Documentar pela linguagem fotográfica 38

2.4 Espraiamento da discussão sobre documentação pedagógica 45

2.5 Panorama da discussão sobre documentação no Brasil 48

2.6 Documentar a partir de histórias de aprendizagem 53

2.7 Visibilidade ao pensamento e às aprendizagens das crianças 57

PARTE II - DECIDIR 63

3 Delimitando o ângulo de visão: a metodologia da pesquisa 64

3.1 Recortes no contexto: o campo de pesquisa 64

3.2 Um zoom na escola: a primeira visita 68

3.3 Projetando o design para imersão no campo de pesquisa 76

3.4 Contextualizando o percurso da pesquisa-ação 83

3.5 Procedimentos de análise 89

3.6 Proposições para análise das fotografias 98

PARTE III - DISCUTIR 103

$4 \quad$ Luzes e sombras: a que processos se escolhe dar visibilidade? 104

$\begin{array}{lll}4.1 & \text { Tateando no escuro } & 107\end{array}$

4.2 Quem tira as fotos? 119

$\begin{array}{ll}\text { 4.3 Que criança se quer comunicar? } & 121\end{array}$

4.4 Como e quando se fotografa? 126

4.4.1 Câmera fotográfica ou aparelho celular? 132

4.4.2 Documentações contextualizadas ou temáticas? 135

4.5 O que se pretende comunicar com as fotografias? 140 
4.5.1 Portfólio da criança 143

$\begin{array}{ll}\text { 4.5.2 Portfólios digitais } & 150\end{array}$

$\begin{array}{lll}4.6 & \text { E os adultos, onde estão? } & 154\end{array}$

PARTE IV - DOCUMENTAR 157

5 Mini-histórias: capturando cenas e atribuindo sentido 158

5.1 Mini-história I 162

$\begin{array}{ll}5.2 \text { Mini-história II } & 164\end{array}$

5.3 Mini-história III 166

$\begin{array}{lll}5.4 & \text { Mini-história IV } & 168\end{array}$

$\begin{array}{ll}5.5 \text { Mini-história V } & 170\end{array}$

$\begin{array}{lll}5.6 & \text { Mini-história VI } & 171\end{array}$

$\begin{array}{lll}5.7 & \text { Mini-história VII } & 173\end{array}$

$\begin{array}{lll}5.8 & \text { Mini-história VIII } & 174\end{array}$

$\begin{array}{lll}6 & \text { Considerações finais } & 177\end{array}$

$7 \quad$ Referências Bibliográficas 184

Apêndice A - Consentimento informado | Crianças 200

Apêndice B - TCLE | Responsáveis pelas crianças 201

Apêndice C - TCLE | Educadoras 203

Apêndice D - Árvore de códigos e dimensões de análise | ATLAS.ti 205

Apêndice E - Nuvem de palavras: "Momentos privilegiados" 206

Apêndice F - Revisão de literatura (2018) | Dissertações brasileiras 207

Apêndice G - Revisão de literatura (2018) | Dissertações brasileiras 208

Apêndice H - Teses e dissertações (2018) 209

Apêndice I - Revisão de literatura (2020) | Universidade do Minho 210

Apêndice J - Revisão de literatura (2020) | Pesquisas estrangeiras 211

Apêndice K - Caracterização dos grupos 212

Apêndice L - Trechos da entrevista com as educadoras (2020) 213

Apêndice M - Trechos da entrevista com as educadoras (2020) 214 
Anexo A - Declaração de Ciência e Concordância (2018 e 2019) 215

Anexo B - Declaração de Ciência e Concordância (2020) 216

Anexo C - Sensibilidade ao design 217

Anexo D - Atributos para qualificação dos espaços públicos 218 


\section{Lista de abreviaturas e siglas}

AEE Atendimento Educacional Especializado

ABD Agency by design

ANEI Avaliação Nacional da Educação Infantil

BNCC Base Nacional Comum Curricular

CIEC Centro de Investigação em Estudos da Criança

CD-ROM Compact Disc Read-Only Memory/ Em português, "Disco Compacto Memória Somente de Leitura"

CRAS Centro de Referência de Assistência Social

DCNEI Diretrizes Curriculares Nacionais para Educação Infantil

CONSED Conselho Nacional de Secretários de Educação

EMEI Escola Municipal de Educação Infantil

FNDE Fundo Nacional de Desenvolvimento da Educação

FUNDEB Fundo de Manutenção e Desenvolvimento da Educação Básica e de Valorização dos Profissionais da Educação

GRUPEM Grupo de Pesquisa em Educação e Mídia

IBICT Biblioteca Digital Brasileira de Teses e Dissertações

INEP Instituto Nacional de Estudo e Pesquisa Educacionais Anísio Teixeira

LDB Lei de Diretrizes e Bases

LIE Laboratório de Informática Educativa

MEC Ministério da Educação

MLV Making Learning Visible

OCDE Organização para a Cooperação e Desenvolvimento Econômico em francês: Organisation de coopération et de développement économiques

PNE Plano Nacional de Educação

PROINFO Programa Nacional de Tecnologia Educacional

PPP Projeto Político-Pedagógico

PPS Project for Public Spaces

PROUCE Programa Um Computador por Educador

PUC-RIO Pontifícia Universidade Católica do Rio de Janeiro

PZ Project Zero

SEB Secretaria de Educação Básica

SECADI Secretaria de Educação Continuada, Alfabetização, 
Diversidade e Inclusão

SINAEB Sistema Nacional de Avaliação da Educação Básica

SMED/DIE Departamento de Informática Educativa da Secretaria Municipal de Educação

TI Tecnologia da Informação

UBS Unidade Básica de Saúde

UNCME União Nacional dos Conselhos Municipais de Educação

UNDIME União Nacional dos Dirigentes Municipais de Educação

UNESCO Organização das Nações Unidas para a Educação, a Ciência e a Cultura

UNICEF Fundo das Nações Unidas para a Infância

VT Visible Thinking 


\section{Lista de Figuras}

Figura 1 - Quadrantes da lente investigativa 26

Figura 2 - Projetando a documentação pela "sensibilidade ao design" 62

Figura 3 - Localização do Município de Erechim-RS 64

Figura 4 - Erechim: "Capital da Amizade" 65

Figura 5 - Localização do Bairro Progresso, Erechim-RS 66

Figura 6 - Prédio da escola 68

Figura 7 - Vista aérea da escola 69

Figura 8 - Sala de aula 70

Figura 9 - Biblioteca e Sala de Recursos/AEE 71

Figura 10 - Laboratório de Informática 72

Figura 11 - Pátio interno 73

Figura 12 - Portfólio do aluno $\quad 74$

Figura 13 - Álbuns de fotografia e outros registros $\quad 75$

Figura 14 - Desenho da Pesquisa de campo 77

Figura 15 - Estrutura e organização da equipe 86

Figura 16 - Caracterização dos grupos $\quad 87$

Figura 17 - Etapas da análise de conteúdo 90

Figura 18 - Categorias e dimensões de análise 94

Figura 19 - Mosaico de significações 101

Figura 20 - Exposição de fotos no corredor 106

Figura 21 - Ambientes invisibilizados 108

Figura 22 - Observação dos espaços administrativos 111

Figura 23 - Observação da hora do lanche 115

Figura 24 - Documentando a hora do lanche 117

Figura 25 - Fotografando em momentos de espontaneidade $\quad 125$

Figura 26 - Documentando vivências de integração 128

Figura 27 - Fotografando vivências dirigidas 130

Figura 28 - Fotografando com câmera fotográfica digital 133

Figura 29 - Documentando movimentos em sequência 136

Figura 30 - Documentação contextualizada 140

Figura 31 - Construindo o portfólio 148

Figura 32 - Interpretando as fotos do portfólio 150 
Figura 33 - Documentando pelas mídias sociais

Figura 34 - Fotografando em equipe 156

Figura 35 - Intersecções entre as aprendizagens 158

Figura 36 - Mini-história I 162

Figura 37 - Mini-história II 164

Figura 38 - Mini-história III 166

Figura 39 - Mini-história IV 168

Figura 40 - Mini-história V 170

Figura 41 - Mini-história VI 171

Figura 42 - Mini-história VII 173

Figura 43 - Mini-história VIII 174 


\section{Lista de Quadros}

Quadro 1 - Características da "boa fotografia" 44

Quadro 2 - Experiências internacionais em destaque 46

Quadro 3 - Roteiro de entrevista| Equipe de gestão 81

Quadro 4 - Roteiro de entrevista/ Professoras 82

Quadro 5 - Projetos temáticos da escola 88

Quadro 6 - Pré-análise: seleção de documentos 91

Quadro 7 - Glossário de códigos 93

Quadro 8 - Dados da categoria: "Luzes" 95

Quadro 9 - Dados da categoria: "Sombras" 96

Quadro 10 - Coocorrência de códigos $\quad 97$

Quadro 11 - Instrumentalidade da fotografia ao educador-investigador 120

Quadro 12 - Como a criança é vista? 123

Quadro 13 - Dimensões da documentação com apoio da fotografia 139 
A câmera faz com que todos sejam turistas na realidade alheia e, eventualmente, na sua própria.

Susan Sontag, "Sobre fotografia" 


\section{Introdução}

Há quem diga que o bom pesquisador é aquele capaz de se afastar totalmente de suas paixões para enxergar com austeridade o objeto que pretende investigar. De fato, a pesquisa é um terreno untuoso, em que se vive tentando encontrar equilíbrio e não escorregar em excessos ou escassez de isenção/neutralidade/imparcialidade. Contudo, assumo que aceitaria a pecha, caso fosse norma ter de renunciar àquilo que nos move e nos constitui, para sermos pesquisadores de excelência. $E$, por esta lógica, também imagino ser impossível apresentar minha tese sem antes narrar fatos pessoais, os caminhos trilhados até aqui, que contribuíram de alguma maneira para a escolha do tema e do objeto que foi estudado. Deste modo, opto por fazê-lo em primeira pessoa, personificando e particularizando a narrativa. Recordar o próprio percurso é um ato desafiador, que implica descrever, decidir, discutir e (por que não?) documentar.

Neste seguimento, reporto-me à minha primeira experiência profissional na educação infantil ${ }^{1}$, em Erechim, norte do Rio Grande do Sul. Minha trajetória profissional começou cedo, aos dezessete anos, estagiando como monitora em uma escola privada. Minha principal tarefa era auxiliar as professoras em vivências do cotidiano escolar, acompanhando as crianças nos cuidados de higiene, na hora do lanche, nas idas ao banheiro e na preparação de materiais pedagógicos. Outra tarefa que cabia às monitoras era o registro fotográfico de propostas vivenciadas pelos grupos ${ }^{2}$ da educação infantil. $\mathrm{Na}$ época (entre os anos 2007 e 2008), a coordenadora pedagógica tinha uma câmera fotográfica digital - que pertencia à escola - e, sempre que solicitado pelas professoras, convocava uma monitora para fazer os registros. Era um momento aguardado por nós monitoras, que disputávamos o "privilégio" de deixar as tarefas corriqueiras para fotografar. Era também uma das poucas possibilidades que tínhamos de sair da escola, pois sempre que a escola promovia um passeio a exposições, teatro

\footnotetext{
${ }^{1}$ No Brasil, o termo Educação Infantil, com iniciais em maiúsculo, se refere à primeira etapa da educação básica, que abrange o atendimento de educação e cuidado a crianças de 0 a 5 anos de idade, em creches e pré-escolas da rede pública ou privada (Brasil, 2009a). No entanto, na escrita da tese, optei por utilizar o termo educação infantil, iniciando com letras minúsculas, englobando termos utilizados por outros países para se referirem à educação de crianças pequenas, a exemplo de Portugal, que se refere ao termo educação da infância.

2 Neste caso, a utilização do termo grupo é equivalente à turma. Na tese, evitei o termo turma, que costuma ser associado a uma organização escolar dos grupos no ensino fundamental e médio da educação básica, afastando a ideia de escolarização precoce das crianças na educação infantil.
} 
ou outros eventos culturais, uma de nós as acompanhava para registrar. Minha frustração nessa época era ter de devolver a câmera à coordenadora ao final de cada sessão, e só ter acesso às fotos que iam para a página da escola na internet, ou quando eram exibidas em eventos comemorativos da escola.

Nesta época, comecei a me aventurar na fotografia e levava minha câmera todos os dias para a escola. Deixava-a no bolso do jaleco e mesmo sem ser solicitada, fotografava os momentos que julgava interessantes. Ao chegar em casa, passava as fotos para o computador, selecionava as melhores e editava da forma que sabia, sem nenhum aprimoramento técnico - avivava as cores, dava mais luminosidade, ajustava a linha do horizonte, aumentava o contraste, recortava etc. Aos poucos, passei a ser considerada a "fotógrafa oficial" da educação infantil. Sentia-me realizada quando algumas fotos eram impressas e expostas nos corredores da escola, principalmente nos espaços em que circulavam pais e responsáveis.

Ainda nessa escola, o ato de fotografar as crianças permaneceu comigo quando passei de estagiária a professora da educação infantil. Desenvolvi, ainda de forma intuitiva, mecanismos de armazenamento das fotos que eram produzidas ao longo do ano, organizando pastas no computador, com data e informações sobre o que era fotografado. Ao final do ano letivo, as famílias enviavam para escola um CD-ROM, para que uma coletânea de fotos digitais fosse gravada, levando para casa uma lembrança da criança e de seu grupo. Ainda não havia uma consciência da importância que minhas fotografias tinham para aquele contexto. Acreditava que fotografar era apenas um gosto pessoal, mas percebia que agradava aos pais - que tinham uma espécie de comprovação de que as crianças eram felizes na escola, que estavam participando de vivências atrativas e sendo bem cuidadas.

Quando fui nomeada ao cargo de professora da educação infantil na rede municipal de Erechim, em 2012, na escola em que fui trabalhar, a coordenação pedagógica orientava as professoras a fotografarem as propostas principais desenvolvidas, como forma de avaliar o desenvolvimento das crianças, porém, os outros registros pedagógicos - anotações nos diários de cada professora e a elaboração de pareceres descritivos - se sobrepunham em relação ao valor que era dado à fotografia. A maioria das professoras da escola já tinha por hábito fotografar as crianças nessa época, agora utilizando mais seus aparelhos celulares do que câmeras. Sem que houvesse um debate sobre isso na escola, algumas professoras compartilhavam as fotos das crianças em suas redes sociais, 
o que acabava servindo de divulgação do trabalho pedagógico desenvolvido, ao mesmo tempo em que as fotos da escola se confundiam e se misturavam com publicações pessoais.

Na rede municipal, minha primeira atuação foi com um Berçário II e um Pré$A^{3}$, quando descobri diferentes possibilidades de exploração dos registros fotográficos que produzia das crianças - a exemplo do dia em que deixei o laptop ligado e abri aleatoriamente uma pasta com fotos da "hora do soninho" ${ }^{4}$, com closes individuais das crianças dormindo. O alvoroço foi grande, os bebês ${ }^{5}$ apontavam e gritavam fascinados ao se verem e identificarem os colegas nas fotos. Comecei, a partir desse dia, a exibir diariamente as fotos para atrair a atenção dos bebês. Ficava espantada com o quanto essa proposta funcionava, e me perguntava como não tinha pensado nisso antes.

Ainda em 2012, participei com o grupo pré-escolar de um estudo etnográfico, que buscava compreender a educação infantil na perspectiva das crianças ${ }^{6}$. Fazia parte da metodologia utilizada pelos pesquisadores fotografar brincadeiras livres, momentos em que as crianças utilizavam estratégias próprias para organização do espaço e criação de suas brincadeiras. Ficava surpresa com o fato de não registrarem somente os momentos em que eu, enquanto professora, conduzia as vivências. Os pesquisadores deixavam as crianças mais livres, o que inicialmente causava a mim estranhamento e angústia, com receio de que a situação fugisse de controle. As fotos eram produzidas em momentos que eu considerava "caóticos", com as crianças em movimento, gritando, sem encarar a lente da câmera nem se prepararem com poses. Lembro, também, de achar interessante o posicionamento espacial de quem fotografava. Embora usassem uma câmera fotográfica profissional que chamava atenção das crianças, os pesquisadores procuravam ficar em um canto, com perspectiva de visão privilegiada, mas

\footnotetext{
${ }^{3}$ Berçário II: crianças com idade entre 1 ano e 1 ano e 11 meses, completos até 31 de março. | PréA: 4 anos a 4 anos e 11 meses, completos até 31 de março.

4 "Hora do soninho" é como costuma ser chamado o momento de descanso das crianças na educação infantil.

${ }^{5}$ Utilizo o termo "bebê" tendo como referência a especificação do documento Práticas Cotidianas na Educação Infantil: bases para a reflexão sobre as orientações curriculares (Brasil, 2009b), que define como bebês as crianças na faixa etária de 0 a 18 meses e como "crianças bem pequenas", as crianças na faixa etária de 19 meses a 3 anos e 11 meses.

$6 \mathrm{O}$ projeto de pesquisa esteve vigente de 2012 a 2014, vinculado à Universidade Federal da Fronteira Sul - UFFS/Campus Erechim-RS, sob coordenação do Prof. Dr. Rodrigo Saballa de Carvalho. O estudo focalizou a perspectiva de crianças de quatro anos de idade, a respeito da proposta de Educação Integral que vinha sendo implantada nas Escolas Municipais de Educação Infantil da cidade de Erechim-RS. A pesquisa procurava romper com a lógica adultocêntrica presente nas teorias tradicionais de socialização, que percebem as crianças apenas como indivíduos passivos que internalizam normas e regras nas instituições, tendo em vista integrarem-se na sociedade.
} 
evitando sempre interferir nas interações das crianças. Era muito diferente da forma que eu fotografava. Em outro momento dessa pesquisa, em pequenos grupos, as crianças se sentavam no chão em círculo e narravam o que viam e o que recordavam a partir das fotos colocadas ao centro. Percebi que nunca tinha proposto um momento de devolutiva das fotos às crianças, nem permitia que elas falassem livremente sobre suas vivências. Pelo contrário, de certa forma, eu impunha minha interpretação sobre as fotos, seja na avaliação das crianças, para outras professoras, equipe gestora ou para os pais. Com esta vivência, passei a questionar as possibilidades interpretativas das crianças em relação às imagens: O que elas pensam das fotos? Que representações reconhecem a partir das imagens? Que narrativas produzem a partir da leitura e interpretação sobre o que veem? É possível responder a estas questões realizando uma pesquisa?

\section{1}

\section{Abertura da lente conceitual}

As experiências que tive com a fotografia como professora na educação infantil, provocaram inúmeras inquietações, muitas das quais trago para a tese. $\mathrm{A}$ constatação de que fotografar é um hábito recorrente entre educadores na educação infantil é consenso, mas perturba saber que não se tem clareza dos motivos pelos quais se fotografa e que explorações podem ser feitas com as fotografias produzidas. Neste sentido, causa desconforto ter de assumir que inúmeras descobertas que fiz sobre o uso da fotografia como um dispositivo pedagógico foram intuitivas, sem que houvesse uma reflexão teórica que subsidiasse o fazer pedagógico. Por conseguinte, emergiram as questões de pesquisa: A que processos se escolhe dar visibilidade com a fotografia na educação infantil? Quem é responsável por fotografar? Que imagem da criança se pretende comunicar? Como e quando as crianças são fotografadas? Como e quando as fotos são publicizadas? Com quem e para quem se compartilha as fotografias? E o fotógrafo, em que oportunidades aparece nas fotos que produz? ${ }^{7}$

Nesta acepção, a presente tese focaliza os registros pedagógicos produzidos com apoio da linguagem fotográfica no contexto da educação infantil. A pesquisa teve como objetivo, sobretudo, compreender e analisar a utilização da

\footnotetext{
${ }^{7}$ As questões norteadoras também foram referenciadas em Malavasi \& Zoccatelli (2019).
} 
fotografia para narrar e documentar as aprendizagens e vivências das crianças em uma escola de educação infantil da rede municipal de ensino da cidade de Erechim-RS.

A imersão no campo de pesquisa se deu por, aproximadamente, oito meses, entre 2018 e 2019, e foi realizada por meio de atividades concomitantes: observação participativa - em espaços de uso coletivo da escola e acompanhamento de quatro grupos de Pré-A; e diálogos transversais - conversas com as crianças, entrevistas com as educadoras e participação em reuniões pedagógicas de formação em contexto ${ }^{8}$. Inicialmente, a pesquisa teve caráter exploratório e, progressivamente, assumiu contorno participante, tendo sido delimitada como pesquisa-ação ${ }^{9}$.Os dados construídos com a imersão no campo foram de natureza diversa notas de campo, gravações de áudio e fotografias produzidas por mim. Parte da análise dos dados foi desenvolvida durante período de doutorado sanduíche no âmbito do Projeto Capes Print, no Centro de Investigação em Estudos da Criança - CIEC, do Instituto de Educação da Universidade do Minho, em Braga/Portugal, no primeiro semestre de 2020, com a colaboração da coorientadora, a professora Dra. Cristina Parente e da orientadora no Brasil, professora Dra. Rosália Duarte. Os dados foram tratados a partir de análise de conteúdo (Bardin, 1977; Bauer, 2008), realizada com apoio do software ATLAS.ti, constituindo-se duas categorias mais amplas - Luzes e Sombras - que elucidam a que processos se dava visibilidade, mas também o que era "invisibilizado" em relação ao modo de fotografar e divulgação das fotografias na escola.

Sabe-se que o ato de documentar com apoio em imagens fotográficas já faz parte do cotidiano da educação infantil (não apenas no Brasil, mas em diferentes contextos a nível global), porém ainda se questiona o uso que é feito dessas imagens, que nem sempre são interpretadas como uma linguagem específica ou como um idioma. Muitos educadores ainda concebem a fotografia como correspondência da realidade, uma evidência dada e que, portanto, não requer interpretação. Assim sendo, propõe-se neste trabalho de investigação uma desconstrução desta noção, para que a fotografia se torne mais do que um simples

\footnotetext{
${ }^{8}$ A formação em contexto foi compreendida a partir de Oliveira-Formosinho \& Kishimoto (2002) e Oliveira-Formosinho \& Formosinho (2001), considerando os processos de formação e investigação centrados na prática profissional de educadores, que se desenvolvem a partir da análise de situações que os próprios educadores experienciam no cotidiano educativo.

9 Thiollent (2001); Demo (2005); Tripp (2005).
} 
registro da criança na escola, que seja lida com o mesmo potencial interpretativo e subjetivo que as palavras, imbuída de significados.

$\mathrm{Na}$ pesquisa, os registros fotográficos foram discutidos a partir da proposta de documentação pedagógica - esta, por sua vez, compreendida em processos de observação atenta e escuta sensível das investigações e aprendizagens das crianças, tendo ancoramento teórico, principalmente, nas contribuições da abordagem pedagógica desenvolvida na cidade de Reggio Emilia, bastante consolidada em relação a uma educação de qualidade voltada para crianças pequenas.

A particularidade da proposta de Reggio Emilia foi construída a partir de uma história de valor cultural compartilhado e de responsabilização efetiva pela educação das crianças, estabelecida logo após a Segunda Guerra Mundial, quando a comunidade se propôs a reconstruir e fortalecer uma sociedade democrática, partindo da centralidade da infância. Nesse contexto de esforço coletivo, destaca-se o pioneirismo do educador Loris Malaguzzi, que propõe que a criança aprenda com "cem linguagens", dando centralidade à dimensão estética e diferentes tipos de registro, entre eles, a fotografia. Por meio de diferentes linguagens, a criança se comunica, se expressa e se relaciona nos ambientes por onde circula e com os sujeitos com os quais convive (Dahlberg; Moss; Pence, 2003; Hoyuelos, 2003; 2006; Edwards; Gandini; Forman, 2016; Rinaldi, 2017).

A construção teórica da tese também compreende uma revisão de experiências empíricas desenvolvidas internacionalmente - em países em que a observação das crianças, a produção de registros imagéticos e as práticas de documentação têm servido à avaliação da qualidade da educação oferecida à infância. Esta agenda global parte da compreensão de que a primeira infância é uma etapa primordial ao desenvolvimento cognitivo e inserção social da criança. Entre as experiências estrangeiras apresentadas nesta revisão, destacam-se: a) Nova Zelândia, que propõe um currículo nacional para as instituições de educação infantil, chamado Te Whakiri, que explora o método de documentação narrativo com criação de learning stories para avaliação das crianças e da qualidade de educação infantil (Carr, 2001; Carr; Lee, 2012); e b) Estados Unidos, com o protagonismo do Project Zero, da Universidade de Harvard, que tem investigado em parceria com pesquisadores de diversos países, formas de tornar as aprendizagens e o pensamento visíveis (Project Zero; Reggio Emilia, 2014). O Brasil se inscreve nesta agenda, mostrando que tem se engajado com a área da educação infantil e procurado minimizar desigualdades, com a inclusão do tema 
em políticas públicas e em sua legislação educacional. Cita-se o caso das DCNEI (Brasil, 1999; 2009) e da BNCC para a Educação Infantil (Brasil, 2017), que vem sendo implementada a nível nacional e tem movido o debate sobre o currículo de creches e pré-escolas.

Integro, desde 2017, o Grupo de Pesquisa em Educação e MídiasGRUPEM, vinculado à PUC-Rio e coordenado pela professora Dra. Rosália Duarte. O grupo vem testando metodologias com maior tradição nos campos de estudos da filosofia da imagãoem, da estética e das artes. Tendo como norte a pesquisa de doutorado realizada por Gonçalves (2019), complementei a análise realizada, testando a metodologia de criação de um atlas, como forma visual de organizar e dar sentido às fotos que foram produzidas durante a pesquisa, seguindo um percurso analítico aberto a partir da apropriação dos escritos do francês, filósofo e historiador da arte, Georges Didi-Huberman.

A etapa de análise das fotografias produzidas por mim se configura como estrutura complementar à discussão dos resultados da pesquisa, em que as imagens foram narradas a partir de mini-histórias (Reggio Children, 2020), uma proposta sensível de compreender o ponto de vista das crianças sobre suas aprendizagens construídas na pesquisa. As imagens fotográficas se reafirmam como instrumento propositivo para educadores, crianças, famílias e comunidade partilharem os processos vivenciados, contribuindo para prática reflexiva de educadores e para a visibilidade das infâncias.

Conforme apresenta a Figura 1, a tese está organizada em torno de quatro partes interdependentes: Descrever; Decidir; Discutir; Documentar. Os quatro termos, iniciados com a letra $D$, remetem a proposições de learning stories método de documentação com produção de narrativas de aprendizagem, desenvolvido pela neozelandesa Margaret Carr $(2001)^{10}$. Os termos foram ressignificados, de modo que anunciam o propósito de cada parte da tese:11

\footnotetext{
${ }^{10}$ Carr (2001) indica quatro propósitos às learning stories: descrever; decidir; discutir; e documentar - os 4Ds.

11 Tendo como inspiração a proposição de Carr (2001), elaborei uma arte para apresentar a organização da tese (Figura 1), que está estruturada a partir dos 4Ds circunscritos nos quadrantes da lente investigativa da pesquisa. A ilustração faz alusão à lente/objetiva de uma câmera fotográfica, representando as etapas da metodologia de documentação de learning stories, adaptadas à abordagem das quatro partes da tese. No corpo do documento, cada parte será precedida por uma capa, com uma arte que anuncia o tema que será abordado. Estas imagens são autorais, compõem acervo pessoal ou banco de imagens gratuito para uso comercial (atribuição não requerida).
} 
I. DESCREVER o processo de elaboração teórica e conceitual da pesquisa.

II. DECIDIR o caminho metodológico para imersão no campo e análise dos dados.

III. DISCUTIR os resultados da análise à luz do referencial teórico estudado e do cruzamento dos dados.

IV. DOCUMENTAR percursos das aprendizagens construídas pelas crianças na pesquisa.

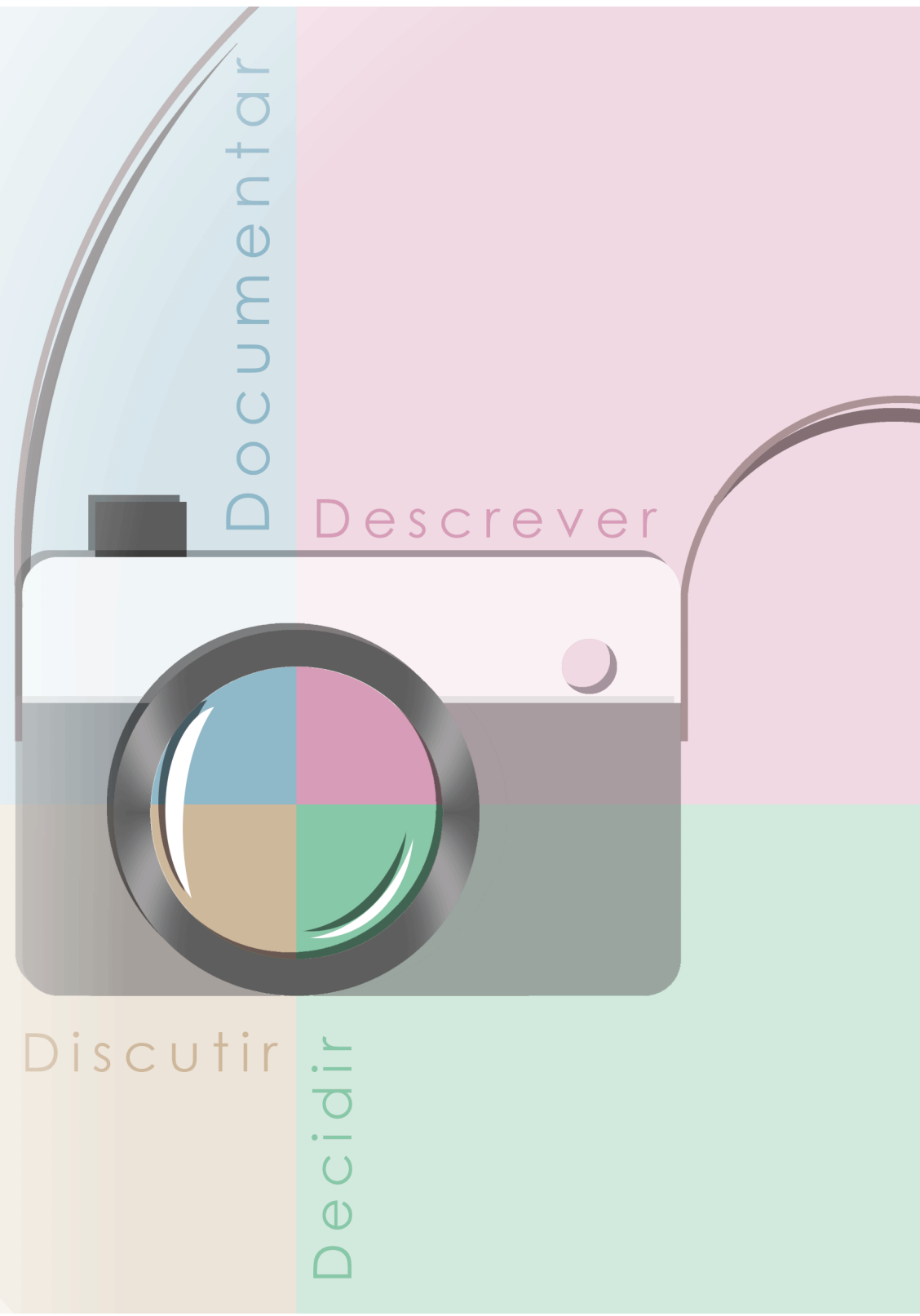

Figura 1 - Quadrantes da lente investigativa Fonte: Elaborado pela autora. 


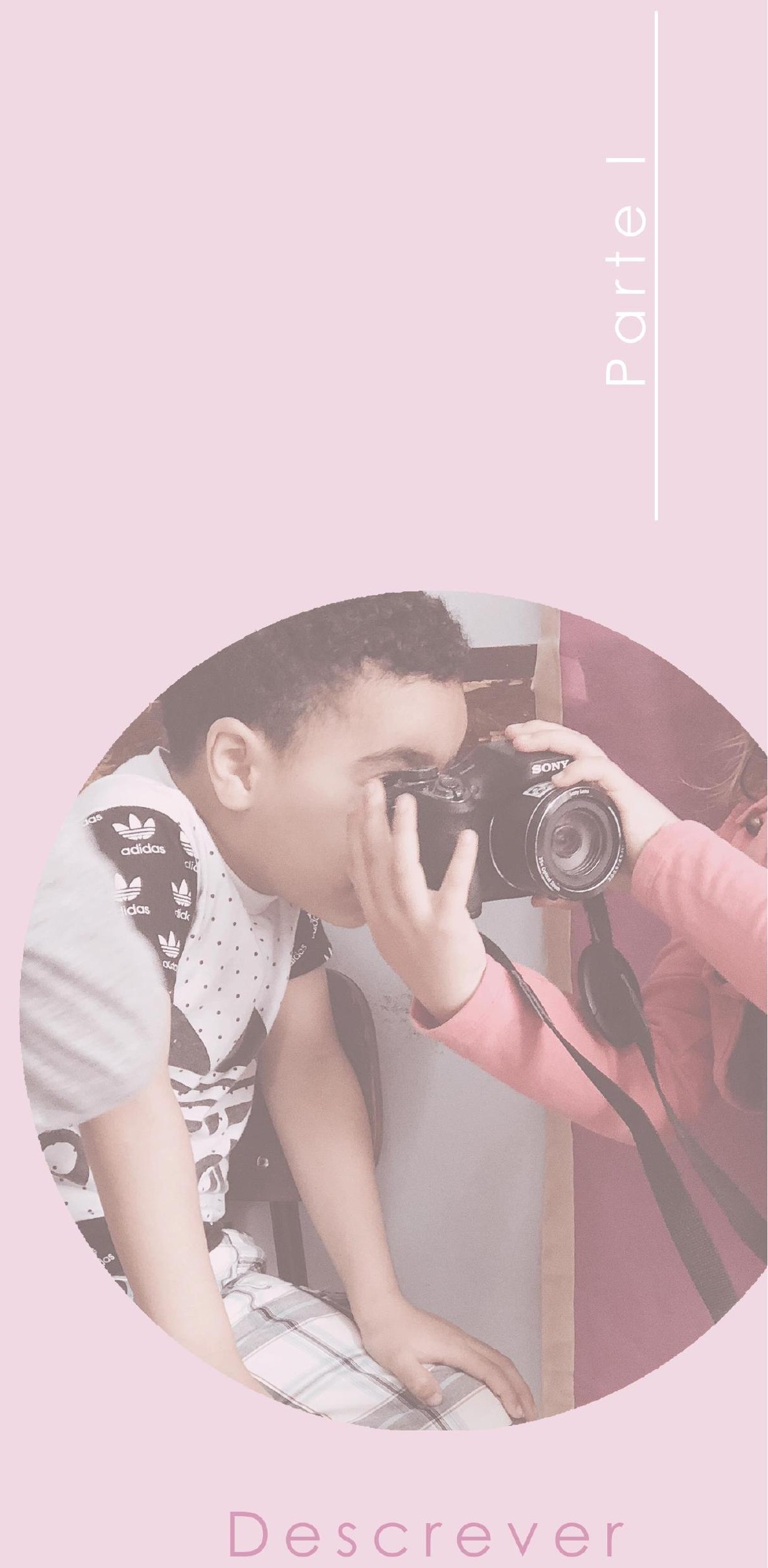




\section{2 \\ Observação, registros e documentação: em busca de uma (re)definição conceitual}

Nos últimos anos, muitos países têm voltado seus olhares para a qualidade da educação oferecida à primeira infância, provocando um processo de desenvolvimento e melhoria de instituições que atendem a crianças pequenas com foco em sua educação e cuidado. A importância que se dá a estas instituições no contexto dos sistemas educativos tem alargado a discussão sobre a observação das crianças e sobre diferentes formas de sistematizar e registrar os processos de aprendizagem. Em paralelo a isso, com a democratização deste debate e a necessidade de avaliar a qualidade da educação oferecida às crianças pequenas, as práticas pedagógicas de observação e documentação ganharam uma nova relevância, responsabilidade e protagonismo.

Com a Convenção sobre os Direitos das Crianças, adotada a partir de 20 de novembro de 1989 pela Assembleia Geral das Nações Unidas, se estabelece como princípio, no $12^{\circ}$ artigo, que "a criança tem o direito de exprimir livremente a sua opinião sobre questões que lhe digam respeito e de ver essa opinião tomada em consideração" (UNICEF, 2019, p. 13). Vinculado a esta e outras conquistas do século $X X$, os registros pedagógicos e a documentação se configuram como possibilidade para agentes educativos em descrever, narrar, interpretar e dar visibilidade às aprendizagens das crianças. Este é um caminho possível para a avaliação da qualidade da educação oferecida para crianças pequenas.

Etimologicamente, a palavra "documentação" deriva do termo em latim documentatio. Em língua portuguesa, pode ser definida por:

\section{documentação}

1. Ato, processo ou efeito de documentar; conjunto de documentos destinado à comprovação ou esclarecimento de algo, documentalística.

2. Pasta ou arquivo de documentos necessários para a identificação de algo (empresa, instituição, bens patrimoniais etc.) ou de alguém (cidadãos, funcionários, presidiários etc.); documentalística.

3. Conjunto de procedimentos (ou cada um deles isoladamente) necessários para a ordenação das informações constantes de documentos de qualquer natureza: seleção, classificação e organização.

4. Organização do acervo de uma instituição (biblioteca, museus, arquivos de escolas etc.), segundo as normas prescritas pela documentologia.

5. Acervo gráfico (manuscritos, cartas, originais de obras etc.) de uma instituição, segundo as mesmas normas. (DOCUMENTAÇÃO..., 2020)

Em âmbito educativo, a documentação se constitui a partir dos registros escritos, visuais ou de áudio de situações vividas em contextos de educação 
infantil. O processo de documentação inclui uma atitude de escuta e observação sensível dos educadores, produção de notas de observação, registro de conversas ou outras situações, registros com apoio em imagens ou vídeos, interpretação desses registros e compartilhamento junto às crianças, a outros educadores e familiares das crianças.

O período de doutorado sanduíche no Centro de Investigação em Estudos da Criança - CIEC, do Instituto de Educação da Universidade do Minho, permitiu uma revisão e aproximação a uma gama de investigações no domínio teórico da Pedagogia da Infância, na perspectiva da Pedagogia-em-Participação, desenvolvida pela Associação da Criança (Oliveira-Formosinho, 2002; Parente, 2002; 2004; 2014; Azevedo, 2009). Com isso, esta pesquisa se delineia em torno de um objeto social na asserção do direito da criança a aprender e participar de sua aprendizagem. Deste objeto social, decorre o objeto científico em que a prática de documentar os processos educativos se inscreve como central para um modelo alternativo de avaliação, onde a criança participa da avaliação de suas aprendizagens, com processos de escuta que levam em conta o que ela pensa e sente. Contudo, os investigadores desse campo sublinham que a qualidade na educação da infância não se constrói somente com a apologia dos direitos das crianças, mas com a garantia desses direitos.

Portugal está entre os países europeus que reconhecem a avaliação na educação das crianças pequenas como competência do educador/professor e como um dispositivo de melhoria da qualidade e equidade da educação infantil. Nos inúmeros desafios que marcam esse debate está a necessidade de que a avaliação seja assumida como "prioridade e prática efetiva, a explicitação da coerência com os princípios de uma abordagem curricular de cariz construtivista centrada na criança competente que se envolve ativamente na construção de conhecimento" (Parente, 2014, p. 168-169).

Oliveira-Formosinho \& Formosinho (2019) sugerem uma pedagogia participativa de educação para infância, menos compartimentada e mais holística do que as pedagogias tradicionais ou transmissivas. As pedagogias participativas envolvem os estudantes em seu próprio conhecimento, visando o desenvolvimento de pessoas responsáveis e cidadãos cívicos. A escola, nesse contexto, também tem seu conceito atualizado; ao invés de uma escola fechada e isolada, tem-se uma "organização ecológica e contextualizada" (p. 20).

Essa abordagem participativa, cultural e socialmente situada, é direcionada para investigar a prática e examinar o que realmente funciona. Um dos pontos 
fortes dessa abordagem é o fato de que os próprios indivíduos envolvidos nas práticas se tornam capazes de avaliar seu contexto, qualificando-o e transformando-o a partir de ações colaborativas que geram aprendizagens. No caso do trabalho com crianças pequenas, essa abordagem requer uma ética específica, que valoriza uma postura transparente entre escola, família e a comunidade em geral. Por esse motivo, em uma pedagogia participativa, o processo de coleta de informações e de avaliação, é visto como forma de melhoria de qualidade. Essa constituição de documentação é responsável por garantir que as experiências de aprendizagem construídas coletivamente e experimentadas pelas crianças sejam valorizadas e exerçam impacto sobre criança, família, comunidade e sociedade.

Nessa concepção de educação da infância, a documentação representa o elo entre duas culturas: a cultura da criança e a cultura do adulto. Esse diálogo é fundamental na (re)construção da realidade educacional inspirada e sustentada em propostas de caráter socioconstrutivista, que reconhecem e valorizam a importância da coparticipação de crianças e adultos nos processos educativos (Azevedo, 2009).

Entre os estudos desenvolvidos por investigadores da Universidade do Minho, destacam-se os que estão inscritos na proposta de Pedagogia-emParticipação, focados na complexidade da documentação pedagógica, configurada em portfólios de aprendizagem, com processos avaliativos que buscam ser equitativos (Formosinho, 2001, 2002; Oliveira-Formosinho, 2002; Oliveira-Formosinho; Parente, 2002, 2004, 2014; Azevedo, 2009).

Conforme indica a $\operatorname{OCDE}^{12}$ (2015), a perspectiva europeia de avaliação da qualidade da educação infantil segue uma tendência que propõe a avaliação do contexto por meio da participação ativa das crianças, com a valorização de suas experiências no espaço escolar. Desta forma, a proposta de Pedagogia-emParticipação se integra a iniciativas que têm sido desenvolvidas em outros países, na tentativa de sistematizar métodos de documentação pensando na qualidade do serviço educativo oferecido para a infância (Carr, 2001; Dahlberg et al., 2003;

\footnotetext{
12 A OCDE foi fundada em 1961, com o objetivo de estimular o progresso econômico e o comércio mundial. É um fórum de países que se descrevem comprometidos com a busca de soluções para uma série de desafios sociais, econômicos e ambientais. Desde a melhoria do desempenho econômico e a criação de empregos até o incentivo à educação sólida e o combate à evasão fiscal internacional, oferecendo uma plataforma para comparar experiências políticas, buscar respostas para problemas comuns, identificar boas práticas e coordenar as políticas domésticas e internacionais de seus membros (Informações disponíveis em: http://www.oecd.org/about/)
} 
Bath, 2012; Carr; Lee, 2012; Project Zero; Reggio Children, 2014; Mitchell, 2018).

Sem desconsiderar a importância desta discussão na contemporaneidade, é necessário o reconhecimento de que a discussão sobre observação, registros e documentação das crianças em espaços educativos vem sendo construída há mais tempo.

A história do desenvolvimento da documentação como um conceito relevante à educação da infância remete à proposta de pensadores que se destacaram do final do século XIX até meados do século XX, entre eles: John Dewey, William Kilpatrick, Célestin Freinet e Loris Malaguzzi. Este último, idealizador da proposta de educação infantil construída na cidade italiana de Reggio Emilia, após Segunda Guerra Mundial, referencia a partir daqui a discussão teórico-metodológica desta pesquisa.

\section{1}

\section{Abordagem pedagógica de Reggio Emilia}

Esta tese se ancora nas principais contribuições da pedagogia italiana desenvolvida pelas pré-escolas da cidade de Reggio Emilia, que tem uma história bastante consolidada de educação voltada para crianças pequenas. Sua posição no contexto da Itália contemporânea e seu compromisso com a etapa da primeira infância revelam que esse reconhecimento foi construído pela particularidade de sua experiência, a partir de uma história de valor cultural compartilhado e de responsabilização efetiva pela educação das crianças (Dahlberg; Moss; Pence, 2003; Hoyuelos, 2003; 2006; Edwards; Gandini; Forman, 2016; Rinaldi, 2017).

Reggio Emilia é uma das cidades bem desenvolvidas de uma região chamada Emilia Romagna, localizada ao norte da Itália. Está situada a 70 quilômetros de Bolonha, tem cerca de 170.000 habitantes e uma economia baseada na agricultura, moda e indústria. Além disso, o trabalho pedagógico com crianças pequenas realizado na cidade é conhecido internacionalmente, pela chamada "abordagem Reggio Emilia". A proposta pedagógica foi estabelecida a partir de 1945, com o fim da Segunda Guerra Mundial, quando um grupo de trabalhadores, formado principalmente por mulheres, decide reerguer a cidade devastada a partir da construção de novas escolas para seus filhos. A necessidade parte da ideia de que deve haver um compartilhamento da responsabilidade pela criação das crianças entre os diferentes setores da sociedade. $O$ grupo queria escolas onde as crianças pudessem vislumbrar um 
futuro diferente da realidade que viviam, onde pudessem adquirir pensamento crítico e habilidades colaborativas, que consideravam essenciais para reconstruir e fortalecer uma sociedade democrática (Hoyuellos, 2003).

Ao fim da Segunda Guerra Mundial, uma comunidade de Reggio Emilia decidiu reconstruir o próprio senso de liberdade e comunidade, partindo da construção de uma escola pensada para crianças pequenas. A primeira escola traz uma inscrição no muro que diz: "Homens e mulheres unidos erguermos as paredes desta escola, porque a queríamos nova e diferente para nossos filhos". Essa metáfora está associada à reconstrução a partir da infância, das crianças, através da afirmação dos direitos de indivíduos (tradução livre, O Começo Da Vida, 2016).

Neste contexto de esforço coletivo, é destacado o pioneirismo de Loris Malaguzzi (1920-1994), pedagogo italiano que teve seu trabalho impulsionado por teorias psicopedagógicas inovadoras na Europa dos anos 1950 e 1960, com base nos estudos de Jean Piaget ${ }^{13}$, Lev Vigotski ${ }^{14}$ e John Dewey ${ }^{15}$ e de pedagogos italianos, como Maria Montessori ${ }^{16}$ e as irmãs Agazzi ${ }^{17}$. O pedagogo visitou a primeira escola construída em Reggio Emilia em 1946, e ali decidiu permanecer, atuando diretamente na construção de uma abordagem com foco nas "cem linguagens da criança" (Edwards; Gandini; Forman, 2016).

\footnotetext{
13 Jean Piaget (1896-1980) foi um biólogo, psicólogo e epistemólogo suíço, considerado um dos principais pensadores do século XX. A partir de observações e registros sistemáticos de seus filhos, Piaget construiu importantes contribuições sobre o desenvolvimento cognitivo humano. Para Piaget, o desenvolvimento cognitivo é organizado e guiado por estruturas mentais inatas, que vão amadurecendo e adquirindo natureza distinta por meio de um processo adaptativo entre o sujeito e seu ambiente ao longo da vida (Souza Filho, 2008).

14 Lev Vigotski (1896-1934) foi um psicólogo russo, proponente da psicologia histórico-cultural. Importante pensador no campo do desenvolvimento e da aprendizagem das crianças. Para Vigotski, aprendizagem e desenvolvimento estão inter-relacionados desde o primeiro dia de vida da criança. Entre seus pressupostos básicos, está a ideia de que o ser humano se constitui na relação com os demais, dando centralidade à linguagem e à cultura (Vigotski, 2009; Souza Filho, 2008).

15 John Dewey (1859-1952) foi um filósofo estadunidense que inspirou um ideal de educação progressista. Postulou que a vida social se desenvolve por intermédio da educação desde a infância, não através da mera transmissão de conhecimentos, mas pela formação de um espírito crítico do aluno. Pensamento, ação e experiência não estão dissociados. Para Dewey (1959, p. 30), "educação é vida, e viver é desenvolver-se, é crescer".

${ }^{16}$ Maria Montessori (1870-1952) foi uma médica e educadora italiana, a primeira mulher a praticar medicina na Itália. Interessou-se pelo desenvolvimento infantil e ficou conhecida pelo método que desenvolveu para a educação de crianças - "método Montessori de aprendizagem", que estimula o equilíbrio entre liberdade e disciplina. Defendia que a criança se desenvolva com interferência mínima de adultos, sejam eles pais ou professores de seu convívio. Sua abordagem educativa possui base na biologia, psiquiatria e antropologia (Montessori, 2006).

17 As irmãs Agazzi - Rosa (1899-1951) e Carolina Agazzi (1870-1945) - foram pedagogas italianas dedicadas à primeira infância. Ficaram conhecidas através da divulgação em congressos de seu trabalho com pré-escolas, quando desenvolveram um método simples, que consistia, entre outros aspectos, em substituir o material tradicional das aulas por atividades da vida cotidiana, como a utilização de materiais recicláveis. A abordagem foi muito difundida na Itália, chegando, em 1948, a ser replicado por $75 \%$ das escolas do país (Rodrigues, 2018).
} 
A criança é feita de cem.

A criança tem cem mãos, cem pensamentos, cem modos de pensar, de jogar e de falar.

Cem, sempre cem modos de escutar as maravilhas de amar.

Cem alegrias para cantar e compreender.

Cem mundos para descobrir. Cem mundos para inventar.

Cem mundos para sonhar (Malaguzzi, 2016).

Malaguzzi propunha que as crianças pudessem aprender e se expressar em diferentes linguagens artísticas, na relação com os pares e com os adultos com os quais convivem. Constituiu um princípio de ensino em que todas as propostas pedagógicas se desenvolvem por meio de projetos. Esses projetos surgem a partir das ideias das próprias crianças e são desenvolvidos pela expressão de diferentes linguagens: pelo desenho, música, movimentos e outras manifestações criativas (Dahlberg; Moss; Pence, 2003; Edwards; Gandini; Forman, 2016; Rinaldi, 2017).

Duas décadas após o início da luta que deu origem à construção das primeiras escolas, a comunidade de Reggio passa a reivindicar a municipalização destes serviços educativos ${ }^{18}$. Em 1963, a cidade inaugura a primeira escola municipal de educação de infância e, ao final dos anos 1970, o sistema de escolas de educação infantil fundado pelo município e centros para crianças de zero a três anos já estava em andamento. Desde então, esses centros atendem a mais da metade da população infantil da cidade (Hoyuellos, 2003).

O projeto educativo de Reggio Emilia é gerenciado pela Reggio Children, uma instituição público-privada, criada em 1994 por iniciativa de Malaguzzi. Localizada na própria cidade de Reggio Emilia, a instituição tem organizado e acompanhado o intercâmbio educacional e cultural da experiência que vem desenvolvendo com educadores e pesquisadores de todo o mundo, tendo como objetivo promover e disseminar princípios para uma educação infantil de qualidade, voltada para a experiência da criança. O sistema inclui, ainda, o Centro Internacional Loris Malaguzzi, os centros infantis e pré-escolas do município.

Nas orientações curriculares italianas do Ministério da Instrução, Universidade e Pesquisa (2015, p. 40), o currículo é pensado como "expressão da liberdade de ensino e da autonomia escolar e, ao mesmo tempo, explicita as escolhas da comunidade escolar e a identidade do instituto". E é com essa construção subjetiva do currículo que se organizam a pesquisa e a inovação educativa. Em referências para a projeção curricular confiada às instituições de

\footnotetext{
18 No Brasil, este processo de municipalização dos jardins de infância ocorreu a partir do início do
} século $X X$. 
ensino italianas, a documentação é entendida como

(...) processo que produz traços, memória e reflexão, nos adultos e nas crianças, tornando visíveis as modalidades e os percursos de formação e permitindo apreciar os progressos da aprendizagem individual e de grupo. A atividade de avaliação na escola da infância responde a uma função de caráter formativo, que reconhece, acompanha, descreve e documenta os processos de crescimento, evita a classificação e o julgamento das obrigações das crianças, porque é orientada a explorar e encorajar o desenvolvimento de todas as suas potencialidades. Analogamente, para a instituição escolar, as práticas de autoavaliação, de avaliação externa, de relato social, visam o melhoramento contínuo da qualidade educativa (Ministério Da Instrução, Da Universidade E Da Pesquisa - Itália, 2015, p. 54)

Em Reggio Emilia, os processos de observação ganham destaque com a construção da proposta de documentação pedagógica, que tem como foco a criança, seus processos, linguagens, pensamentos e modos de ser, além de privilegiar uma discussão sistemática a respeito dos registros produzidos. De acordo com Rinaldi (2017, p. 179), na abordagem de Reggio, a documentação é compreendida "como uma tentativa de fazer justiça à criatividade e à riqueza que ocorrem todos os dias quando procuramos entender e apoiar o processo de aprendizado da criança e do educador".

Nesse sentido, a documentação também se constitui como material investigativo, mediante a materialização das narrativas de aprendizagens e vivências de adultos e crianças. Entende-se que é um valioso instrumento para professores, crianças e comunidade educativa que, ao partilhar os processos vivenciados no cotidiano das ações pedagógicas, contribui para a postura reflexiva dos professores e a visibilidade das crianças.

Nos últimos anos, as discussões teóricas a partir da abordagem de Reggio Emilia têm elaborado uma importante diferenciação entre os conceitos de observação das crianças e de documentação pedagógica - embora os investigadores reconheçam que há uma forte conexão entre ambos (Dahlberg; Moss; Pence, 2003).

Em Reggio Emilia, a concepção de documentação pedagógica parte de uma crítica à utilização tradicional do conceito de observação, que no entender de Malaguzzi, se limitava à prática de descrever e compreender o processo de desenvolvimento psicológico das crianças a partir da identificação do nível ou estágio em que se demonstram determinadas habilidades face a um padrão normativo esperado para cada faixa etária. Sob esta perspectiva, a observação serviria exclusivamente para "mapear uma realidade social universal e objetiva" (Dahlberg; Moss; Pence, 2003). 
A crítica se refere à atitude de muitos educadores que pretendem classificar ou categorizar as crianças a partir de uma série de capacidades esperadas para a idade em que elas se encontram. A proposta de documentação pedagógica desenvolvida em Reggio Emilia se diferencia da utilização tradicional de observação das crianças quando se propõe a uma atitude local, contextualizada e processual, construída na parceria entre crianças e professores e se integra a todas as propostas desenvolvidas pelas escolas.

\section{2 \\ Dimensão estética na proposta de Reggio Emilia}

Alfredo Hoyuelos (2003; 2006) tem dedicado seus estudos a compreender peculiaridades da abordagem pedagógica de Reggio Emilia. Além de ter escrito uma biografia de Loris Malaguzzi, em um livro mais recente, Hoyuelos (2006) desenvolve a fundo a significação da estética no pensamento pedagógico e na vida cotidiana de escolas infantis. Para o autor, o diálogo permanente entre a estética e a ética as torna indissociáveis no pensamento e na ação pedagógica cotidiana construída em Reggio.

Malaguzzi decidiu incluir em todas as escolas infantis de Reggio Emilia, um ateliê conduzido por um profissional com formação estética. Sem desmerecer ou diminuir o papel dos professores/pedagogos, a inclusão do trabalho do atelierista foi responsável por levar para a escola e para os processos de aprendizagem uma nova perspectiva de costumes à tradição pedagógica. Na experiência de Reggio Emilia com o ateliê, a dimensão estética encontra uma expressão importante e tangível, no trabalho com linguagens visuais, que por sua natureza são sensíveis e estão próximas de todas as outras linguagens poéticas (Hoyuelos, 2006).

A atelierista Vea Vecchi (2006) ressalta a dimensão estética como um aspecto que contribui para a evolução e consolidação da filosofia e da prática pedagógica das escolas de Reggio Emilia. Para ela, trata-se de uma atitude cotidiana, da relação empática e sensível que se estabelece com o entorno e com o ambiente. A dimensão estética como parte integrante de uma estrutura de pensamento que sempre é capaz de processos de evolução e desenvolvimento, e que nas situações de aprendizagem pode sustentar e alimentar um conhecimento que não só se nutre de categorias, mas também constrói uma relação sensível e de empatia, possibilitando a criação de inúmeras conexões.

No que diz respeito aos processos de aprendizagem da criança, Vecchi (2006) acredita que a sensibilidade estética é responsável por estabelecer elos 
entre as coisas em si. É pela estética que as crianças fazem determinadas escolhas, como preferir um gesto a outro, selecionar determinado objeto, escolher uma cor ou um pensamento. "São escolhas em que se percebe harmonia, cuidado, prazer para mente e para os sentidos" (tradução livre, p. 17).

Vecchi (2006) problematiza os motivos pelos quais na escola a dimensão estética tem sido considerada um interesse superficial, principalmente no que diz respeito aos cuidados com o bem estar no ambiente e no espaço escolar como um todo. Sinaliza que o sentimento estético ocupa com facilidade diversos campos, é transversal em várias disciplinas, e não está somente ligado à arte. $\mathrm{A}$ atelierista defende a importância de que as crianças e todas as pessoas que trabalham na escola passem o dia em um ambiente onde as cores e os objetos sejam dispostos com cuidado e atenção. Para isso, todos os atores da escola, sejam eles crianças ou adultos, devem se sentir parte na formação e conservação de um ambiente agradável, contribuindo de diferentes formas para esse objetivo.

Ainda nessa perspectiva, Vecchi (2006) destaca que sua defesa do trabalho com a dimensão estética no âmbito escolar não é apenas pelo papel importante que a pedagogia de Reggio Emilia atribui a ela, mas que é necessário compreendermos a estética como uma especificidade inerente ao ser humano, presente nas mais diferentes culturas, atuais e passadas.

A atenção estética é entendida e vivida como filtro de interpretação do mundo, como atitude ética, uma forma de pensamento que requer atenção, graça e ironia, um enfoque mental que supera a simples aparência das coisas e que mostra aspectos e qualidades inesperadas e impensadas a elas (tradução livre, Vecchi, 2006, p. 18).

A dimensão estética está posta em uma relação de tensão entre razão e emoção, na qual paradigmas se renovam. Nesse contexto, o papel do ateliê tem sido desenvolver uma ação dialética com a pedagogia, em que a imaginação e a razão têm sido confrontadas continuamente na busca de equilíbrios e alternâncias, construindo por meio da educação e da aprendizagem, espaços inovadores e muito interessantes (Hoyuelos, 2006).

Nesse contexto, a dimensão estética do processo de registro e documentação ganha relevo e se manifesta "pela qualidade da escuta, pela abertura e sensibilidade para conectar-se ao outro e ouvi-lo, com compromisso e disposição de acolher sua voz com todos os sentidos" (Haddad, 2017, p. 10). 


\section{3 \\ Documentar pela linguagem fotográfica}

Colecionar fotos é colecionar o mundo. Filmes e programas de televisão iluminam paredes, reluzem e se apagam; mas, com fotos, a imagem também é um objeto, leve, de produção barata, fácil de transportar, de acumular, de armazenar (Sontag, 2004, P. 41).

Desde sua invenção, no século XIX, a imagem fotográfica e sua constante evolução vem moldando a experiência dos indivíduos com a realidade, seja como forma de narrar o mundo, registrar sua diversidade, até seu aspecto estético e subjetivo, ligado à emoção e à cultura. Com a ascensão das tecnologias digitais e mídias de massa, a noção de fotografia evolui ao lado da própria discussão teórica que vem sendo construída sobre a imagem (Barthes, 1984; Ibañez, 1986; Morin, 1997; Kossoy, 2001; Bauer; Gaskell, 2008; Flusser, 2002; Sontag, 2004; Moran; Tegano, 2005; Moran, 2009).

Ibañez (1986, p. 17) elaborou o que chamou de "didática da imagem", partindo da ideia de que "tudo é imagem", pois é a partir da imagem que se reconhecem os objetos desde a mais tenra idade. Para ele, nem todas as imagens são uma criação particular, pois algumas são apresentadas à criança desde o seu nascimento. E é pelas imagens que os indivíduos tomam consciência das qualidades sensíveis dos objetos, com a possibilidade de alterar ou conservar estas imagens com o passar do tempo.

Para Ibañez (tradução livre, 1986, p. 18), uma única imagem é capaz de suscitar muito além do que ela está mostrando:

1. É um documento informativo.

2. Assinala o espetacular.

3. Provoca recordações de outras imagens.

4. Se dirige à emotividade.

5. É realista.

6. É algo que já não existe. É passado. É ausência.

7. Pode trazer à tona conteúdos díspares: solidariedade $X$ egoísmo etc.

No mundo da informação real, Ibañez (1986, p. 25) destaca o protagonismo das imagens técnicas, como é o caso da fotografia. Com a imagem técnica, aproxima-se o realismo psicológico do intelectual, ao passo que se está disposto a estímulos sensitivos e perceptivos que afetam diretamente nossa imaginação e cuja credibilidade ultrapassa a barreira de todo raciocínio consciente. Diante deste mundo exacerbado de imagens, o sujeito consegue encontrar e exercer sua liberdade assumindo estas condições que impõe a linguagem das imagens. Para 
o autor, o que vemos e o que imaginamos nos é dado por quem é detentor do poder para usar essa linguagem.

O entorno iconográfico que nos cerca multiplica a realidade e a modifica constantemente. Como consequência disso, amplia-se também a atividade perceptiva. O mundo da percepção chega a substituir o mundo das condições reais em que se desenvolve nossa existência, possibilitando modos de vida reais ou inventados através das imagens (tradução livre, Ibañez, 1986, p. 28).

Assim, com o hábito de viver com uma profusão de imagens técnicas/ produzidas pelo outro, de acordo com lbañez (1986, p. 28), "a subjetividade elabora um inconsciente que substitui o real pelo imaginário". O realismo de imagens técnicas, tais como a fotografia, proporciona uma fidelidade que ultrapassa as percepções reais. A verdade já não se encontra na banalidade da vida cotidiana, mas na utopia dos modelos propostos pelas imagens.

Susan Sontag (2004) ${ }^{19}$ é responsável por uma importante reflexão sobre a fotografia na relação com questões de tempo e espaço, aproximação do real e da verdade. A autora discute não apenas a questão filosófica de como a realidade pode ser percebida e o conhecimento adquirido, mas também revisa a fotografia em seu contexto: como uma ferramenta, uma indústria, uma atividade que transforma a maneira de ver o mundo e, portanto, é capaz de alterar a realidade.

Ao nos ensinar um novo código visual, as fotografias modificam e ampliam as nossas ideias sobre o que vale a pena olhar e sobre o que temos o direito de observar. Constituem uma gramática e, mais importante ainda, uma ética do ver. Por fim, o resultado mais extraordinário da atividade fotográfica é dar-nos a sensação de que podemos reter o mundo inteiro em nossa cabeça - como uma antologia de imagens. (Sontag, 2004, p. 41)

No âmbito da pesquisa e da formação de professores de educação infantil, a utilização da fotografia com a função de registro e para documentar práticas pedagógicas, foi contemplada nos estudos da americana Mary Jane Moran $(2009)^{20}$. A autora concebe, sob uma perspectiva de investigação, a utilização da

\footnotetext{
19 A obra On Photography, que reúne seis importantes ensaios de Susan Sontag, foi publicada originalmente em 1977. No Brasil, foi traduzida por Rubens Figueiredo e publicada pela Companhia das Letras com o título "Sobre fotografia", em 2004.

20 Mary Jane Moran é professora da The University of Tennessee/ Knoxville e diretora do departamento em Estudos da Criança e da Família. Sua pesquisa está focada na prática crítica e reflexiva de professores da primeira infância. Estuda o impacto de uma variedade de contextos no desenvolvimento profissional de professores, local e globalmente. Atualmente, realiza um estudo longitudinal da prática dos professores vinculados ao projeto Head Start e desenvolvimento de liderança e agência.
} 
fotografia como pensamento ou linguagem visual, que opera de maneira interpretativa.

De acordo com Moran e Tegano (2005), a fotografia pode ser compreendida como uma linguagem visual que compartilha de características importantes da linguagem verbal, tanto em aspectos comunicativos quanto estruturais. As autoras elaboram uma crítica ao uso feito pelos professores à fotografia, argumentando que muitos não a tratam como um idioma. Para elas, os professores costumam ver a fotografia como uma verdade, um fato óbvio e que, portanto, não requer interpretação. Propõem que haja uma desconstrução desta noção, para que a fotografia se torne mais do que um simples registro em sala de aula, que seja lida com o mesmo potencial interpretativo e subjetivo que as palavras, imbuída de significado.

Desde o princípio, na experiência educativa de Reggio Emilia existe a constante preocupação de se registrar tudo o que acontece com as crianças durante os processos pedagógicos desenvolvidos pela escola e a fotografia é parte importante desse registro. Na década de 1970, Malaguzzi convidou uma de suas atelieristas, Vea Vecchi, para elaborar painéis com fotografias das crianças. Os painéis foram exibidos em uma exposição, chamada "Il piccione" ("O pombo"), explorando a documentação sob uma perspectiva de qualidade visual. Com a exposição, Vea Vecchi conseguiu convencer Malaguzzi de que as imagens permitem narrar histórias do cotidiano da escola (Fochi, 2015).

Sobre a forma particular de observação e documentação dos processos de aprendizagem utilizados nas instituições de Reggio Emilia, Vecchi (tradução livre, 2006, p. 21) pontua que é:

\footnotetext{
Um sistema de documentação nascido de um grande e frutífero trabalho de elaboração sobre esses temas. A observação e a documentação são uma teoria educativa que a filosofia pedagógica de Reggio Emilia tem sustentado e praticado, utilizando uma dupla modalidade de linguagens: a escrita e a das imagens (grifo meu).
}

Além de reforçar a importância de todos os registros escritos produzidos pelo professor no desenvolvimento do processo pedagógico, a proposta educacional de Reggio Emilia dá centralidade aos registros feitos com o uso de imagens, tal como a fotografia que é feita pelos próprios professores. Essa etapa importante da documentação pedagógica tem, por exemplo, o papel de narrar diferentes processos vividos durante a realização de uma ação pedagógica, desde seu planejamento de execução até o produto final. De acordo com Edwards, 
Gandini e Forman (2016), isso é possível com a composição de um "espaço que documenta". Sendo assim, fotografias e outros registros visuais podem ser expostos pela escola de diferentes maneiras: com exposição de painéis, portfólios, dossiês, folders, livretos, slides e até pela exibição de vídeos.

De acordo com Haddad (2017), o registro precisa ser exercitado para além da escrita. É nesse contexto que a fotografia desempenha grande papel e ao lado de áudio e vídeo-gravações constituem importantes elementos que "possibilitam captar vozes e ações de crianças sobre as culturas infantis". Para a autora, "documentar é parte integrante do cotidiano da educação infantil, alimenta o planejamento, comunica, dá visibilidade ao cotidiano pedagógico" (p. 10).

Destaca-se, ainda, a importância do planejamento para o processo de construção da documentação com o uso de imagens. É imprescindível que o professor planeje de forma objetiva e precisa, para saber eleger com mais assertividade quais instrumentos serão escolhidos para produzir os dados.

Documentar com o uso de fotografias exige também uma reflexão sobre o olhar de quem fotografa - nesse caso, o olhar do próprio professor. Tal como sugere Kossoy (2001), é necessária uma "alfabetização do olhar" para que se enxergue com complexidade uma imagem fotográfica. Embora a fotografia possa produzir registros, estes não são uma mera reprodução do real, pois o olhar do fotógrafo e as condições técnicas, sociais e culturais de produção do registro é que permitem recriar a realidade. Nesse sentido, o autor pondera:

\footnotetext{
Toda fotografia é um testemunho segundo um filtro cultural, ao mesmo tempo em que é uma criação a partir de um visível fotográfico. Toda fotografia representa o testemunho de uma criação. Por outro lado, ela representará sempre a criação de um testemunho (Kossoy, 2001, p. 50).
}

Os estudos do referido autor (Kossoy, 2001) apontam ainda que a fotografia seria uma transposição de realidades, formada no processo de criação e de composição da imagem. Desta forma, ela nunca é uma cópia fiel de apenas uma realidade, uma vez que conta com as escolhas do fotógrafo. Esse processo de produção da fotografia, que engloba diversos elementos, é o que compõe um registro visual.

Embora Kossoy (2001) afirme que um registro fotográfico compõe uma totalidade indivisível, quando se trata da fotografia numa acepção metodológica, o autor indica a necessidade de conceber duas dimensões interpretativas: uma análise técnica, que indicaria as informações implícitas, e a análise iconográfica, 
que ressalta informações explícitas do objeto visual. Assim, o trabalho do fotógrafo deve englobar o processo de produção da fotografia, levando em conta as técnicas, condições e recursos utilizados, até chegar à cena representada.

Pesquisadores dedicados ao estudo da imagem fotográfica como uma linguagem específica, fazem referência ao recurso interpretativo dos leitores, que é socialmente partilhado (Barthes, 1984; Ibañez, 1986; Morin, 1997; Kossoy, 2001; Bauer; Gaskell, 2008; Flusser, 2002; Moran, 2009; Sontag, 2004; Moran; Tegano, 2005).

$O$ ato de ler um texto ou uma imagem é, pois, um processo interpretativo. O sentido é gerado na interação do leitor com o material. O sentido que o leitor vai dar irá variar de acordo com os conhecimentos a ele(a) acessíveis, através da experiência e da proeminência cultural. Algumas leituras podem ser bastante universais dentro de uma cultura; outras serão mais idiossincráticas. (Bauer; Gaskell, 2008, p. 324)

Moran e Tebano (2005) consideram que, à medida em que as fotografias são visualizadas, os revisores decodificam ou "leem" o significado. A leitura de fotografias leva a uma série de interpretações. Para as autoras, essa variedade de interpretações da fotografia pode ser um grande aliado do professor, pois é com o compartilhamento de significados diversos, que novos entendimentos são construídos em parceria com a criança - o que as autoras chamam de "coconstrução". Por esta perspectiva, pode-se considerar que as fotografias são culturalmente situadas e, consequentemente, transmitem significados diferentes para espectadores também diferentes, com base nas experiências, conhecimentos e perspectivas pessoais da vida. Fotografias, como palavras, são codificadas e decodificadas com significado.

Essa ideia de que as fotografias são culturalmente situadas e seu processo "co-construtivo" de interpretação são o argumento central de uma pesquisa com um grupo de pesquisadores e professores americanos e italianos da primeira infância, que coletivamente explorou a alfabetização visual (Fu; Goldhaber; Tegano; Stremmel, 2000). Nessa investigação, a fotografia é utilizada como instrumento investigativo, para compreender a capacidade das imagens de descobrir, provocar e comunicar crenças e práticas relacionadas ao ensino e aprendizagem. A equipe passou quase dois anos refletindo sistematicamente sobre fotografias selecionadas do contexto de cada participante, buscando compreender como a comunidade interpretativa encontraria significados para elas, com inspiração na abordagem da documentação pedagógica de Reggio Emilia. Nas análises dos dados coletados neste projeto, uma questão central 
surge sobre o contexto das fotografias: que história está sendo contada, a história do sujeito, do fotógrafo, do espectador ou as três? Dependendo da resposta a esta pergunta, surgiriam outras indagações: a) Se for a história do fotógrafo, quem vê as fotos sem conhecer sua intenção corre o risco de uma interpretação menos autêntica? b) Até que ponto podemos alcançar o significado autêntico da imagem para crianças ou adultos na imagem? c) Somos capazes de ser autênticos em nossa interpretação? Isso importa? d) A quem pertence o significado? Podemos perder o que não é nosso?

Ostetto (2017, p. 20) também destaca a função comunicativa dos registros produzidos a partir de observação, quando diz que "uma das principais razões da documentação é possibilitar o diálogo com todos os envolvidos, buscando reconhecer cada vez mais crianças e seus percursos de conhecimento e desenvolvimento".

Cipollini (2007, apud Malavasi; Zoccatelli, 2019, p. 64) refletiu sobre os sentidos atribuídos ao gesto de fotografar as crianças, destacando alguns aspectos que o fotógrafo precisa focar, para aprimorar suas habilidades para a linguagem fotográfica:

- Habituar a mente a ver sem filtros mentais. Aquilo que vemos na objetiva ${ }^{21}$ será aquilo que ficará registrado, nem mais nem menos (não pressupor nada).

- Fazer uma seleção consciente daquilo que aparece no enquadramento. Nunca enquadrar casualmente: cada elemento que aparece na imagem deverá ter um sentido.

- Definir, do ponto de vista funcional e de harmonia, o ângulo de captura, perspectiva e fundo. Estas escolhas referentes ao enquadramento servem para compor os diversos elementos que constituem a imagem da forma mais clara e expressiva possível.

- Avaliar a luminosidade: define e caracteriza o sujeito.

- Escolher o momento da captura: é o mais indicado para definir a situação que pretendemos documentar? A fotografia das crianças raramente é estática.

O Quadro 1 designa alguns pontos-chave importantes na composição de uma "boa fotografia"22:

\footnotetext{
21 No português falado em Portugal, o termo objetiva possui sentido equivalente ao que no Brasil chamamos de lente fotográfica.

${ }^{22}$ Conteúdo complementar a este pode ser consultado no Caderno 3, do documento Documentação pedagógica: Textos complementares, publicado pelo Ministério da Educação com apoio da UNESCO (2018). Texto referência: Elementos complementares da linguagem fotográfica (MEC/UNESCO, 2018, p. 13).
} 


\title{
O que compõe uma boa foto?
}

\begin{tabular}{|c|c|}
\hline Primeiro plano & As expressões do rosto são mais evidentes. \\
\hline Fotografia simples & $\begin{array}{l}\text { Quanto menos elementos as compõem, mais clara e unívoca é a } \\
\text { mensagem que transmitem. }\end{array}$ \\
\hline $\begin{array}{r}\text { Ausência de elementos } \\
\text { perturbadores }\end{array}$ & $\begin{array}{l}\text { Atenção ao fundo da foto, às sobreposições, aos elementos que } \\
\text { atraem o olhar mas são estranhos à mensagem que se quer } \\
\text { transmitir. }\end{array}$ \\
\hline Boa luz & $\begin{array}{l}\text { Luz que põe evidência e valoriza os elementos principais da } \\
\text { imagem. }\end{array}$ \\
\hline
\end{tabular}

Quadro 1 - Características da "boa fotografia"

Fonte: Cipollini (2007, apud Malavasi e Zoccatelli, 2019, p. 64), adaptado pela autora.

Ainda que reconheçam a importância do aprimoramento "técnico" para melhoria da qualidade das fotografias, Malavasi \& Zoccatelli (2019, p. 66) consideram que "o pressuposto necessário para aprender a fazer boas fotografias, em termos de documentação educativa, é sobretudo aprender a observar as crianças".

\begin{abstract}
A documentação visual pode oferecer contextos e oportunidades para dar visibilidade e valor também ao papel e ao trabalho dos educadores, que frequentemente, tendem a excluir-se da possibilidade de serem fotografados na sua posição junto às crianças e a "desaparecerem" nas situações que ajudaram a criar (Malavasi; Zoccatelli, 2019).
\end{abstract}

Para Vecchi (2017), a valorização da linguagem visual tem aumentado a cultura e a sensibilidade estética dos educadores e pedagogos, já que para comunicar de modo significativo, as imagens requerem olhares sensíveis e capacidade de captar com profundidade os acontecimentos. Nesse projeto educativo, a escuta é indispensável, é uma atitude de respeito com as crianças. $\mathrm{Na}$ escola, todos os processos de ensino e aprendizagem fazem parte de um processo de escuta e sintonia recíproca, de observação sensível que busca conhecer e entender a criança enquanto sujeito de direito.

Gambetti \& Gandini (2020) assinalam que, para fotografar as crianças em contextos educativos, é necessário que o adulto esteja aberto ao inesperado. Contudo, de modo contraditório, muitos educadores esperam resultados positivos, mas como esses encontros são ricos em reviravoltas inesperadas, suas expectativas são frequentemente superadas pela grande capacidade criativa das crianças. 


\section{4}

\section{Espraiamento da discussão sobre documentação pedagógica}

Ao início dos anos 2000, com o aumento do acesso a transportes aéreos, publicações globais e telecomunicações (incluindo a democratização da internet), a abordagem de Reggio Emilia passa a ser discutida em instituições acadêmicas e comunicada a partir de conferências ao redor do mundo. Nesta época, o interesse de pesquisadores estrangeiros era compreender o que diferenciava a experiência de Reggio da prática desenvolvida em pré-escolas de seus países, além de identificar aspectos que poderiam ser replicados, principalmente em relação à documentação pedagógica. Com o espraiamento de sua experiência, a abordagem de Reggio passa atrair os olhares do mundo, tornando-se um produto global, que influenciou em diversos países, um movimento que coloca em evidência a necessidade de reformulação de currículos e de mudanças significativas nas práticas de educação de crianças pequenas. Essa constatação da necessidade de transformação do currículo da educação infantil deu origem a experiências que propunham a prática de documentação e observação para avaliar as crianças. Diferentes países têm mencionado a documentação em seus planos de educação e currículos como indicador ou critério de qualidade. Cita-se como exemplo: Suécia (Emilson; Pramling-Samuelsson, 2014), Finlândia (Rintakorpi, 2016), Nova Zelândia (Carr; Lee, 2012) e Inglaterra (Bath, 2012).

Uma pesquisa realizada pela Fundação Maria Cecília Souto Vidigal, em parceria com a Fundação Carlos Chagas (2018), investigou experiências desenvolvidas em 12 países, sobre a elaboração e acompanhamento de políticas públicas com foco na melhoria da qualidade da educação infantil. A pesquisa revelou que das 12 nações estudadas, cinco contam com políticas bem estruturadas de avaliação da qualidade da educação infantil dando peso maior para a avaliação da criança: Dinamarca, Espanha, França, Inglaterra e Suécia. Nas propostas de avaliação das crianças elaboradas por estes países, destacamse estratégias de documentação das vivências das crianças com registros sistemáticos das aprendizagens. O Quadro 2 apresenta os principais aspectos desenvolvidos nesses países, relativos a duas categorias: a organização do currículo e a estrutura de políticas para avaliação das crianças. 


\begin{tabular}{|c|c|c|}
\hline \multicolumn{3}{|c|}{ Experiências internacionais em destaque } \\
\hline País & Diretrizes curriculares & Avaliação das crianças \\
\hline Dinamarca & $\begin{array}{l}\text { Cada unidade de ensino deve compor um } \\
\text { currículo para crianças de } 0 \text { a } 2 \text { anos e outro } \\
\text { para a faixa de } 3 \text { a } 5 \text { anos. O documento tem } \\
\text { de ser aprovado por autoridades locais, } \\
\text { juntamente com as famílias. A base para a } \\
\text { elaboração do documento são cinco objetivos: } \\
\text { o desenvolvimento individual integral; as } \\
\text { competências sociais; a linguagem; o } \\
\text { desenvolvimento do corpo e do movimento; e o } \\
\text { cultivo de valores culturais e artísticos. }\end{array}$ & $\begin{array}{l}\text { Possui uma avaliação de linguagem para ser } \\
\text { aplicada às crianças de } 3 \text { anos, que apresentem } \\
\text { alguma dificuldade de linguagem e/ ou de } \\
\text { comportamento. Crianças dessa idade, que não } \\
\text { frequentem nenhum tipo de atendimento infantil, } \\
\text { também devem passar por essa avaliação. Há } \\
\text { uma avaliação do currículo feita por especialistas } \\
\text { e famílias, a cada dois anos. Todas as } \\
\text { informações ficam disponíveis num sistema único } \\
\text { do governo. }\end{array}$ \\
\hline Espanha & $\begin{array}{l}\text { Em 2007, o governo nacional estabeleceu as } \\
\text { áreas de conhecimento com as quais os } \\
\text { conteúdos devem trabalhar. A cada instituição } \\
\text { cabe produzir a própria proposta pedagógica, } \\
\text { baseada nessas áreas. Os conteúdos têm de } \\
\text { ter como foco o desenvolvimento do } \\
\text { conhecimento de si e a autonomia pessoal; o } \\
\text { conhecimento do entorno; as linguagens e } \\
\text { suas representações. }\end{array}$ & $\begin{array}{l}\text { A avaliação se baseia em entrevistas com os pais } \\
\text { e a observação cotidiana dos tutores. O foco é } \\
\text { individual: a criança deve ser comparada a ela } \\
\text { mesma, com respeito ao seu ritmo. No final de } \\
\text { cada ciclo, os tutores elaboram um documento } \\
\text { formal com essas informações, mas o contato } \\
\text { com os pais deve ser constante. }\end{array}$ \\
\hline França & $\begin{array}{l}\text { Não há um currículo nacional. Apenas } \\
\text { diretrizes que os currículos devem seguir para } \\
\text { a faixa etária dos } 2 \text { aos } 5 \text { anos de idade. Os } \\
\text { domínios de aprendizagem nos quais os } \\
\text { currículos devem se basear são: mobilizar a } \\
\text { linguagem em todas as suas dimensões; agir } \\
\text { e se expressar por meio da atividade física; } \\
\text { agir e se expressar por meio das artes; } \\
\text { construir ferramentas para estruturar o } \\
\text { pensamento e explorar o mundo. }\end{array}$ & $\begin{array}{l}\text { O sistema de avaliação francês coloca como } \\
\text { ponto central a importância de observar o } \\
\text { progresso da criança em relação a si e não em } \\
\text { relação aos colegas. Os professores efetuam o } \\
\text { monitoramento e o registro do desenvolvimento de } \\
\text { cada aluno ao longo de todo o ano e fazem a } \\
\text { avaliação no final do ciclo. Não há registros de } \\
\text { orientação de avaliação de crianças com menos } \\
\text { de } 3 \text { anos de idade. }\end{array}$ \\
\hline Inglaterra & $\begin{array}{l}\text { Possui um currículo nacional desde } 2002, \\
\text { baseado em objetivos de aprendizagem, } \\
\text { sistematizados por áreas: linguagem, } \\
\text { letramento, matemática, compreensão do } \\
\text { mundo, artes, desenvolvimento físico e } \\
\text { emocional. Esses objetivos devem ser } \\
\text { seguidos por qualquer tipo de atendimento } \\
\text { infantil, voltado para crianças de } 0 \text { a } 5 \text { anos de } \\
\text { idade - de escolas formais a independentes, } \\
\text { academias, escolas livres e cuidadores } \\
\text { comunitários. }\end{array}$ & $\begin{array}{l}\text { Os professores fazem uma avaliação anual da } \\
\text { criança, com base somente na observação. Não } \\
\text { há nenhum tipo de teste. Alguns dos princípios } \\
\text { que norteiam essa observação são: o } \\
\text { conhecimento do professor sobre a criança; as } \\
\text { ações que a criança consegue fazer, de maneira } \\
\text { consistente e independente em várias situações } \\
\text { do dia a dia; e levar em conta diferentes } \\
\text { perspectivas de avaliação, como o ponto de vista } \\
\text { da própria criança, dos pais e de outros adultos } \\
\text { relevantes para ela. }\end{array}$ \\
\hline Suécia & $\begin{array}{l}\text { O ponto central da educação infantil sueca } \\
\text { são os valores democráticos dessa sociedade, } \\
\text { no caso, cultivar a liberdade individual, a } \\
\text { integridade, o valor igual de todas as pessoas, } \\
\text { a igualdade de gênero e a solidariedade com } \\
\text { pobres e vulneráveis. }\end{array}$ & $\begin{array}{l}\text { Conta com diferentes formas de registro, sendo } \\
\text { duas delas o portfólio de trabalhos da criança e a } \\
\text { documentação pedagógica. Nessa } \\
\text { documentação, há o uso do learning histories } \\
\text { (narrativas em que os educadores detalham o } \\
\text { processo de aprendizagem da criança, em } \\
\text { diferentes atividades, normalmente com o auxílio } \\
\text { dos pais). }\end{array}$ \\
\hline
\end{tabular}

Quadro 2 - Experiências internacionais em destaque

Fonte: Fundação Maria Cecília Souto Vidigal e Fundação Carlos Chagas (2018).

Embora os dados apresentados no Quadro 2 não tragam de forma explícita o detalhamento do trabalho pedagógico e as propostas desenvolvidas por cada uma das experiências estrangeiras, percebe-se que os países possuem em 
comum a aposta em um currículo com foco na criança, na observação, nos registros e na documentação. Contudo, sabe-se que a importação pura de modelos desenvolvidos por outros países costuma não ser tão bem-sucedida, o que incentiva um estudo mais detalhado de cada contexto para que se identifiquem suas especificidades ou possíveis fragilidades.

Paralelamente ao crescimento do sucesso de Reggio Emilia, surgiram críticas à forma como seu modelo de observação passou a ser replicado mundialmente. Isto porque, conforme explicitado anteriormente, o modelo italiano se apresenta como uma proposta genuinamente local e contextualizada, e outros países passam a replicá-la como proposta de avaliação da educação infantil em larga escala, como foi o caso de experiências avaliadas nos Estados Unidos, Austrália (Grieshaber; Hatch, 2003) e Inglaterra (Bath, 2012).

Nos Estados Unidos e na Austrália, a partir dos anos 2000, noções sobre observação da criança passaram a ser usadas para tomada de decisões curriculares. Oficialmente, a proposta curricular e de avaliação da criança, nos dois países, possuía referência na abordagem de Reggio Emilia - que compreende a observação como parte do processo de documentação pedagógica, sob uma perspectiva holística das crianças (Dahlberg; Moss; Pence, 2003). No entanto, ao serem entrevistados, professores americanos e australianos se queixam de que o uso da observação na avaliação das crianças vinha servindo para atender expectativas externas sobre o progresso acadêmico das crianças, o que contraria a proposta italiana (Grieshaber; Hatch, 2003).

No Reino Unido, uma avaliação de experiências que tinham como inspiração o modelo de documentação pedagógica de Reggio Emilia (Bath, 2012), e vinham sendo desenvolvidas a partir dos anos 2000 , indicou que, no geral, mesmo quando havia um grande esforço dos educadores em promover a participação das crianças no processo de recolhimento de registros, as crianças continuavam não se envolvendo por completo nos momentos pedagógicos, o que também contraria os pressupostos que sustentam a proposta italiana. A pesquisa aponta como aspecto principal nesta ausência de estímulo, o fato de as crianças não terem acesso aos registros escritos que eram realizados pelos educadores. Embora houvesse uma tentativa de replicar o modelo, a documentação das propostas pedagógicas desenvolvidas em escolas inglesas mantinha o foco na opinião dos adultos, frequentemente sobrecarregando educadores e apontando continuamente para a necessidade de maior participação dos pais.

A apresentação das experiências desenvolvidas em outros países nos põe 
diante de uma agenda internacional, que parte da compreensão de que a primeira infância é uma etapa primordial ao desenvolvimento cognitivo e inserção social da criança. O Brasil se inscreve nesta agenda, mostrando que tem se engajado com a área da educação infantil com a inclusão do tema em políticas públicas e em sua legislação educacional.

\section{5 \\ Panorama da discussão sobre documentação no Brasil}

As primeiras experiências e publicações acadêmicas desenvolvidas no Brasil que discutiam práticas educativas de observação e documentação dos processos educativos tinham como foco o registro docente (Freire, 1983; 1996; Warschauer, 1993; Magalhães; Marinceck, 1995) e apontavam, predominantemente, para a necessidade de formação continuada (autoformação) do professor, considerando que "registrar é escrever sobre sua prática, anotações para análise e reflexão" (Ostetto, 2017, p. 20). A prática do registro do cotidiano já era reconhecida como essencial, tanto para qualificação do fazer educativo, como para a formação docente. As experiências das crianças, pensamentos e vivências também estavam presentes nesta discussão, no entanto, não se mostravam o foco central dos registros dos quais se debatia.

Madalena Freire $(1983 ; 1996)$ se destaca como uma das primeiras referências sobre o tema em experiências brasileiras. Seus estudos apontam para a importância do registro diário como documento e instrumento de contínua reflexão do professor sobre sua prática.

Através dessa reflexão diária [o professor] avalia e planeja sua prática. Ele é também um importante documento, onde o vivido é registrado, juntamente com as crianças. Nesse sentido, educador e educando, juntos repensam sua prática (Freire, 1983, p. 77).

Luciana Ostetto (2008) marca a importância do registro docente para documentação pedagógica no Brasil com a produção de um ensaio que deu visibilidade a diferentes interlocutores, identificando nas propostas educativas desenvolvidas no norte da Itália, particularmente na cidade de Reggio Emilia, "um canal fecundo para a ampliação da reflexão e colocando em diálogo as experiências italianas e brasileiras" (Ostetto, 2017, p. 20). 
Documentar é contar histórias, testemunhar narrativamente a cultura, as ideias, as diversas formas de pensar das crianças; é inventar tramas, poetizar os acontecimentos, dar sentido à existência, construir canais de ruptura com a linguagem "escolarizada", tradicionalmente cinzenta, rígida, enquadrada, que tantas vezes silencia adultos e crianças. Documentação é autoria, é criação (Ostetto, 2017, p. 20).

Em 1988, com a promulgação da Constituição Federal, a educação infantil passa a ser considerada a primeira etapa da educação básica no Brasil. Esta ideia é reforçada pela Lei de Diretrizes e Bases da Educação Nacional (LDB), em 1996. No entanto, apenas dez anos depois, em 2006, com a criação do Fundo de Manutenção e Desenvolvimento da Educação Básica e de valorização dos Profissionais da Educação (Fundeb) é que se provê recursos para a oferta de creche às famílias brasileiras.

De lá para cá, o percentual de crianças atendidas por creches praticamente dobrou, para $34,1 \%$, de acordo com os dados do anuário Todos Pela Educação (2019), referente ao período de 2002 a 2017. Entre as crianças de 4 a 5 anos, na pré-escola - etapa em que a educação infantil passa a ser obrigatória - a taxa de atendimento atingiu $93 \%$, no mesmo período. O documento também aponta para a questão da equidade, quando diz que "o sistema brasileiro reproduz diversas desigualdades sociais" (Todos Pela Educação, 2019, p. 24), o que se evidencia com a análise de recortes da oferta de creche e pré-escola por região, localidade, renda e raça/cor.

$25 \%$ das crianças pertencentes aos domicílios que estão no quartil mais baixo de renda estão nas creches, enquanto $55 \%$ das que estão nos domicílios mais ricos frequentam a etapa (Todos Pela Educação, 2019, p. 24).

Ainda que a legislação brasileira tenha acompanhado a percepção da importância da educação oferecida às crianças pequenas e que a desigualdade entre ricos e pobres no acesso à creche e pré-escola venha caindo a cada ano, os desafios postos à educação infantil no Brasil não se extinguem, e giram em torno de outras questões, como:

- A relação entre a expansão das creches e a qualidade do atendimento (um ponto de difícil resolução, dado que as crianças pequenas requerem mais atenção, portanto, mais pessoal, que precisa ser bem treinado).

- A formação pouco adequada dos professores. O curso de pedagogia forma professores desarticulados das questões da primeira infância - a maneira como eles aprendem é disciplinar, fragmentada em campos de conhecimento, e a educação infantil propõe outra lógica, holística, baseada em interações e brincadeiras. 
- O financiamento ainda precário e os baixos salários dos docentes, um obstáculo para a atração dos profissionais mais talentosos.

- A escassez de programas consistentes de formação continuada para os profissionais

- Dificuldades na relação entre unidades de educação infantil e famílias.

- A escassez de estudos que mostrem estratégias que seriam mais eficazes ou menos eficazes na formação dos professores. (Fund. Maria Cecília Souto Vidigal; Fund. Carlos Chagas, 2018, p. 07)

Atualmente, o Brasil aposta na correção de desvios que tenham impacto negativo na qualidade da educação infantil por intermédio da BNCC - Base Nacional Comum Curricular. A proposta de definição de uma base comum surge com o intuito de elevar a qualidade de ensino em todo o país através da definição e garantia de direitos à aprendizagem da criança.

A BNCC se constitui como "um documento de caráter normativo que define o conjunto orgânico e progressivo de aprendizagens essenciais que todos os alunos devem desenvolver ao longo das etapas e modalidades da Educação Básica" (Brasil, 2017). A elaboração do documento ocorreu a partir de um intenso processo colaborativo, participativo e de disputas, que teve início em 2015 e culminou em 2017, quando a versão final é publicada. Atualmente, a BNCC é a principal referência nacional para formulação de propostas curriculares, a fim de estabelecer níveis de aprendizagem e desenvolvimento aos quais todos devem ter acesso, sem que se exclua a pluralidade, diversidade e especificidades a nível local, adequando-se à realidade das escolas e dos alunos. Na etapa da educação infantil, a proposta está em pleno processo de implementação, o que envolve debate para adequação dos currículos em todos os municípios e formação aos professores. O documento retoma aspectos das Diretrizes Nacionais Curriculares para a Educação Infantil (DCNEI) (Brasil, 2009a), como: a concepção de criança; a dimensão de cuidar e educar; os eixos estruturantes das práticas pedagógicas, englobando as interações, brincadeiras e os direitos de aprendizagem e desenvolvimento.

A discussão sobre uma educação infantil de qualidade atualiza a necessidade sobre a criação de políticas para avalição desta etapa educativa em escala nacional. No Brasil, este debate se fortalece em 2012, com a formulação do Plano Nacional de Educação (PNE), que determinou como uma das estratégias de melhoria da qualidade, a necessidade de realização de avaliação sistemática em caráter de larga escala.

Uma iniciativa mais concreta direcionada à criação de uma proposta de avaliação da educação infantil no Brasil ocorre no âmbito Ministério da Educação 
(MEC) e da Secretaria de Educação Básica (SEB), com a criação de um grupo de trabalho que elabora um documento que discute diretrizes e aspectos de configuração para esta avaliação. O princípio fundante deste documento estipula que a avaliação precisava fortalecer uma concepção de educação infantil que vinha sendo construída socialmente e não poderia ser utilizada de forma a fragilizá-la. A partir desse momento, o INEP - Instituto Nacional de Estudo e Pesquisas Educacionais Anísio Teixeira, que até então não possuía atuação direta ou iniciativas específicas que visassem avaliar a educação infantil do país, passa a coordenar o debate e constituir grupos de trabalho e comissões de especialistas e de entidades, tais como UNDIME (União Nacional dos Dirigentes Municipais de Educação), CONSED (Conselho Nacional de Secretários de Educação) e UNCME (União Nacional dos Conselhos Municipais de Educação).

Passou-se a pensar a avaliação da educação infantil no Brasil de forma integrada, contando com colaboração das próprias instâncias do MEC, como da SEB, do FNDE (Fundo Nacional de Desenvolvimento da Educação) e da SECADI (Secretaria de Educação Continuada, Alfabetização, Diversidade e Inclusão extinta em janeiro de 2019).

Esta ação conjunta coordenada pelo INEP culmina em 2015, com a elaboração de uma proposta que fornecia elementos para operacionalização de uma avaliação da educação infantil. Assim, em 2016, é publicado um decreto que institui o SINAEB - Sistema Nacional de Avaliação da Educação Básica (em substituição ao SAEB), e dentro desse sistema é reconhecida e caracterizada a Avaliação Nacional da Educação Infantil - ANEl.

Como a política não foi implementada até hoje e tem perdido espaço no debate governamental a nível nacional, as instituições brasileiras orientam seu currículo através das Diretrizes Curriculares Nacionais para Educação Infantil (DCNEI) (Brasil, 2009a) e da BNCC (Brasil, 2017), que tem impulsionado iniciativas isoladas de avaliação do serviço, do contexto e das crianças na educação infantil de forma integrada, com a garantia de seis direitos de aprendizagem da criança, a conviver, brincar, participar, explorar, expressar e conhecer-se.

As DCNEl orientam que as instituições criem dispositivos não só para documentar as descobertas e aprendizagens das crianças, mas também para acompanhar o trabalho pedagógico desenvolvido junto a elas, visto que, nesta etapa educativa, as expectativas de aprendizagem, das crianças devem estar vinculadas às experiências educativas oportunizadas neste ambiente (Moreira, 
2015).

Embora as DCNEl continuem em vigor no Brasil, percebe-se que as instituições enfrentam dificuldade de colocar em prática os preceitos do documento. Entre as hipóteses que justificam isso, está o desconhecimento do documento, o pouco acesso a ele ou a indicação de seu "caráter mandatório" (Fund. Maria Cecília Souto Vidigal; Fund. Carlos Chagas, 2018, p. 17).

Em 2018, na etapa de qualificação do projeto de pesquisa da tese, realizouse uma revisão de pesquisas empíricas sobre práticas de observação, registro e documentação na educação infantil no contexto brasileiro, que foi sistematizada a partir de sínteses reflexivas de dissertações e teses defendidas em programas de pós-graduação de universidades do país, publicadas entre 2008 e 2018. Buscouse por produções acadêmicas disponibilizadas por duas bases de dados virtuais: o Catálogo de Teses \& Dissertações/CAPES e a Biblioteca Digital Brasileira de Teses e Dissertações (IBICT). A busca pelos títulos e palavras-chave das pesquisas foi orientada pelo uso de descritores, flexionando os termos: "documentação", "documentar", "narrar", "documentação pedagógica", "observação", "registros", "portfólio", "crianças", "bebês", "infância(s)" e "educação infantil". Foram localizadas 17 pesquisas, consideradas mais próximas da temática em estudo na tese, sendo que delas: 13 eram dissertações de mestrado (Machado, 2009; Baracho, 2011; Vieira, 2013; Fochi, 2013; Lichy, 2014; Amaral, 2014; Medrado, 2014; Moreira, 2015; Merli, 2015; Ferraresi, 2015; Kawada, 2016; Bartholomeu, 2016; Ramos, 2016) e 4 eram teses de doutorado (Mendonça, 2009; Marques, 2011; Simiano, 2015; Horn, 2017) ${ }^{23}$.

A quantidade de pesquisas localizadas em 2018 já sinalizava que nos últimos anos vem crescendo o interesse de pesquisadores por investigar as práticas de registro e documentação das vivências e aprendizagens das crianças na educação infantil no contexto brasileiro. A revisão mostra que as pesquisas a nível de mestrado e doutorado no Brasil têm compartilhado o interesse pela compreensão da observação e da documentação na educação infantil, dando centralidade aos processos formativos experienciados pelos educadores. Nesse sentido, os pesquisadores têm se proposto a investigar registros dos diários de campo, registros escritos dos professores, registros imagéticos e relatos que se transformaram em instrumento de avaliação e investigação dos percursos vividos

23 A sistematização desta revisão consta em: Apêndice $F$; Apêndice $G$ e Apêndice $H$, deste documento. 
nas instituições de educação da(s) infância(s). No que tange à apropriação e (re)elaboração do conceito de documentação pedagógica, as pesquisas fazem interlocução, predominantemente, com a abordagem pedagógica de Reggio Emilia, situando-se na perspectiva de uma pedagogia para a infância inspirada na proposta italiana, mas que necessita de reconhecimento e adequação à realidade brasileira. Os resultados destas pesquisas reafirmam a importância de construção de políticas voltadas para a formação continuada dos professores na educação infantil e apontam a documentação pedagógica como um elemento imprescindível a propostas que visam uma pedagogia da escuta, da visibilidade e da comunicação entre crianças, professores e famílias.

Tendo como pressuposto o que foi debatido a partir da revisão, sinaliza-se que a contextualização apresentada nesta etapa da pesquisa carece de atualização, reconhecendo a importância de que sejam revisadas publicações acadêmicas que tenham sido publicadas a partir de 2019 - sistematização que não fora contemplada na tese. Destaca-se, também, a necessidade de ampliação deste debate, considerando as transformações impostas à realidade das crianças no Brasil a partir de 2020 pela pandemia de Covid-19, que provocou o fechamento de creches e pré-escolas e isolamento social.

\section{6 \\ Documentar a partir de histórias de aprendizagem}

Conforme discutiu-se no item anterior, alguns países têm se destacado com o desenvolvimento de experiências de avaliação das crianças utilizando como estratégia a documentação. Destes países, merece destaque a Nova Zelândia, onde as instituições de educação infantil seguem um currículo nacional obrigatório, chamado Te Whakiri, introduzido a partir de 1996. Em maori, o termo Te whakiri significa "tecido"; e o currículo recebe esse nome pois espera-se que as metas e ações educativas se entrelacem harmonicamente como em um tear, para que se alcance um resultado positivo. A noção de pertencimento é central ao currículo da Nova Zelândia, com enfoque principal à diversidade cultural do país. O ensino bilíngue (em inglês e maori), conteúdos e formas de trabalhar, ressaltam o respeito à individualidade e às diferenças étnicas. Os princípios que regem o currículo são: o empoderamento da criança - que the permita ser agente de seu desenvolvimento, o desenvolvimento integral, a parceria da família e da comunidade e relações de reciprocidade (New Zealand Now, 2020). 
O sistema de educação infantil da Nova Zelândia não aplica testes formais. A estratégia de avaliação que tornou o currículo do país reconhecido internacionalmente aposta na elaboração da documentação com learning stories (Carr, 2001; Carr; Lee, 2012), que em português pode-se traduzir por "histórias de aprendizagem". O método criado por Margaret Carr (2001) se configura como um tipo de documentação narrativa, como oportunidade para professores, crianças e pais darem visibilidade às aprendizagens, apresentando-as por meio de: narrativas escritas, apresentações digitais, gravações de vídeo, fotografias digitais e produções da criança.

Carr (2001) assume um interesse particular pelo aspecto narrativo da avaliação, sugerindo que adultos e crianças contem e recontem as histórias de aprendizagem, para que possam refletir sobre situações passadas e auxiliar o planejamento futuro. A pesquisadora indica que a learning story e o portfólio sejam revisitados pelas crianças e pelos adultos para que se reconheçam os percursos de aprendizagem e para que estes sejam validados em conjunto. No reconhecimento de seu trabalho, a pesquisadora indica quatro propósitos às learning stories: descrever, decidir, discutir e documentar - os 4Ds.

O uso de learning stories como instrumento avaliativo nas instituições de educação infantil da Nova Zelândia segue uma perspectiva sociocultural e ecológica prevista pelo currículo nacional, Te Whakiri. A elaboração do currículo teve como base as contribuições de Vigotkski a respeito da aprendizagem, envolvendo questões sobre: pertencimento, participação, brincar, comunicação e linguagem, e bem-estar na relação com o outro (Carr; Lee, 2012).

Ao longo de 20 anos desde sua criação, o método de documentar com histórias de aprendizagem vem sendo aprimorado a partir de pesquisas acadêmicas e empíricas, e essa evolução também inclui os avanços tecnológicos. Para que todos tenham acesso às learning stories, tem-se criado diferentes formatos digitais de apresentação, que podem ser adaptadas de acordo com cada contexto. Na Nova Zelândia, o sistema de educação garante uma variedade de recursos eletrônicos e tecnológicos às instituições. A maioria das instituições de educação infantil do país são equipadas com câmeras fotográficas digitais para uso pedagógico, podendo ser utilizadas pelas próprias crianças (New Zealand Now, 2020).

Pesquisadores têm se proposto a investigar o compartilhamento de histórias de aprendizagem em plataformas online, com a análise de portfólios digitais, que são construídos pela combinação de registros em formato digital - fotos e vídeos 
- com narrativas textuais sobre as aprendizagens das crianças (Picher, 2019; Beaumont-Bates, 2017; Arndt; Tesar, 2015). A inovação deste formato de documentação está no fato de as histórias de aprendizagem podem ser elaboradas tanto por educadores quanto pelas famílias.

Picher (2019) analisou histórias de aprendizagem compartilhadas por escolas canadenses que utilizam uma plataforma chamada Storypark ${ }^{24}$. A autora justifica a popularidade da plataforma por sua versatilidade, pois permite que educadores de qualquer lugar do mundo criem histórias de aprendizagem que se conectam com currículos específicos ou "conjuntos de aprendizagem", como são chamados na plataforma. Assim como o advento da própria história de aprendizagem (Carr, 2001; Carr; Lee, 2012), a plataforma permite a complexidade envolvida na documentação e na avaliação holística do desenvolvimento das crianças pequenas (Oliveira-Formosinho; Formosinho, 2019). Com a análise de mais de 500 postagens na plataforma, Picher (2019) identificou quatro possíveis categorias para o formato das histórias de aprendizagem, sendo elas: A. Autoexplicativa; B. Descritiva; C. Direcionada e D. Aprofundada.

A. As histórias de aprendizagem "autoexplicativas" são histórias em que se apresenta uma imagem sem fornecer qualquer descrição ou explicação adicional. Podem ser apresentadas com ou sem título. Muitas vezes o título é composto por apenas uma palavra-chave, como associação direta ao que é representado na imagem.

B. As histórias de aprendizagem "descritivas" são histórias nas quais se fornece uma breve descrição de um momento ou vivência de aprendizagem em que a criança esteve envolvida, juntamente com uma foto. A qualidade da comunicação das histórias de aprendizagem "descritivas" varia quanto à superficialidade ou aprofundamento que pode ter. Estas histórias de aprendizagem podem ser individuais, de pequenos grupos ou do grupo inteiro.

C. As histórias de aprendizagem "direcionadas" são histórias que se dirigem

24 O Storypark é uma plataforma de documentação digital desenvolvida com a consultoria de educadores de infância da Nova Zelândia e especialistas de outros países, permitindo que educadores e pais registrem e compartilhem a aprendizagem de seus alunos/filhos por meio de textos, imagens, gravações de vídeo e/ou áudio. A ferramenta foi desenvolvida originalmente em 2011, para atender a necessidades de avaliação dos educadores da primeira infância a partir da abordagem do currículo Te Whāriki. Atualmente, a plataforma é utilizada por mais de 7.000 usuários em 38 países (Picher, 2019). 
diretamente a determinado público, podendo ser às famílias, a outros grupos de crianças, educadores ou à comunidade em geral. A qualidade de comunicação destas histórias de aprendizagem também varia quanto ao nível de superficialidade e aprofundamento. As histórias de aprendizagem "direcionadas" podem ser apresentadas a partir de um "anúncio" ou como "extensão". Na escola, o "anúncio" pode chamar atenção dos pais quando os educadores desejam fazer um convite, por exemplo. Já a "extensão" tem como objetivo estender o aprendizado. Por exemplo, educadoras podem estender uma aprendizagem que iniciou na escola para o ambiente doméstico.

D. As histórias de aprendizagem "aprofundadas" são histórias nas quais se fornece uma análise mais aprofundada de aprendizagem individual, em pequenos grupos ou do grupo todo. Tal como sugere o nome, a qualidade de comunicação destas histórias de aprendizagem é a mais aprofundada. $\mathrm{Na}$ escola, estas histórias podem ter como foco a aprendizagem ou comportamento de uma criança específica ou em determinada vivência.

A pesquisa de Beaumont-Bates (2017) obteve resultados significativos relacionados aos portfólios digitais:

- Os portfólios digitais servem como incentivo para o desenvolvimento de parcerias colaborativas entre educadores, família, crianças e a comunidade em geral.

- Facilitam a comunicação entre família e escola, já que a aprendizagem e o desenvolvimento das crianças são compartilhados de forma mais rápida e com maior frequência, estabelecendo parcerias colaborativas mais eficazes.

- Com os portfólios digitais, pais e educadores estabelecem um meio alternativo de se comunicarem, o que alivia a pressão para que esse diálogo ocorra nos horários de chegada e saída das crianças da escola.

- Entregando feedback por meio de portfólios digitais, os educadores conseguem responder mais rapidamente às famílias.

- Quando os pais participam da elaboração dos portfólios digitais de seus filhos, os educadores se sentem mais amparados para planejarem ações de aprendizagem para as crianças.

- Os portfólios digitais fornecem aos educadores uma melhor compreensão do contexto das crianças, para além da escola, o que contribui para uma 
avaliação mais aprofundada.

- Incentivo aos pais a se envolverem mais na aprendizagem de seus filhos.

- Os portfólios digitais contribuem para que família e criança conversem mais sobre o dia-a-dia da criança na escola.

- Com os portfólios digitais, a parceria com as crianças melhora como resultado secundário da colaboração aprimorada entre educadores e família.

\section{7}

\section{Visibilidade ao pensamento e às aprendizagens das crianças}

O Project Zero (PZ) possui uma trajetória de pouco mais de 50 anos, foi criado em 1967 e idealizado pelo americano Nelson Goodman. Está vinculado à Harvard School Graduate of Education, situada à cidade de Cambridge Massachusetts, nos Estados Unidos. A questão que move o projeto desde sua criação gira em torno do pensamento, ou sobre como seria possível acessar o pensamento para que se compreendam os caminhos que os indivíduos percorrem para construírem diferentes aprendizagens ao longo da vida. Esta inquietação, de caráter mais amplo, deu origem a inúmeras pesquisas com focos específicos, que vêm sendo desenvolvidas em mais de 30 projetos abarcados pelo $P Z$, que envolvem pesquisadores e educadores estadunidenses em parceria com diferentes instituições educativas nos Estados Unidos e em outros países - como a Itália, através de uma aproximação com a proposta de Reggio Emilia.

A ideia de tornar as aprendizagens visíveis está fortemente contemplada pelo projeto Making Learning Visible (MLV) - em português, "Tornando a Aprendizagem Visível"), que aposta na presença da documentação em sala de aula, com apoio em registros de gravação de áudio e vídeo. O projeto foi criado em 1997, quando pesquisadores e educadores do Project Zero estabelecem uma parceria com as pré-escolas de Reggio Emilia, buscando compreender no contexto da prática o que os educadores italianos faziam em sala de aula que os diferenciava na atitude de documentar os processos de aprendizagem. As pesquisas tentavam responder como era possível que crianças pequenas criassem possibilidades de aprendizagem, tendo a documentação produzida pelo grupo como suporte para o desenvolvimento de seu pensamento individual e coletivo. Hoje, o esforço dos pesquisadores envolvidos com as pesquisas do MLV tem sido em deslocar os resultados do trabalho de documentação alcançado com 
crianças pequenas para processos de aprendizagem de alunos de outras faixas etárias: crianças maiores, adolescentes e adultos (MLV; PZ, 2005; 2006).

As pesquisas do PZ que investigam formas de dar visibilidade ao pensamento e às aprendizagens revelam que a documentação assume diferentes propósitos durante etapas de aprendizagem também diferentes. Contudo, o critério que diferencia a qualidade da documentação depende do contexto de experimentação, levando em conta se o foco está realmente em determinado aspecto da aprendizagem e não apenas como mera comprovação do que vem sendo realizado pela escola. Além disso, os estudos no âmbito do projeto MLV têm pontuado que a documentação deve ser capaz de promover debates entre crianças e adultos, de forma que aprofunde e alargue seus aprendizados (MLV; $P Z, 2005)$.

Em momentos de formação pedagógica com foco na discussão sobre como tornar as aprendizagens visíveis pela documentação, investigadores envolvidos em projetos do $\mathrm{PZ}$ sugerem que o próprio educador faça a si algumas questões, que podem ser adaptadas de acordo com o contexto de atuação de cada um (MLV; PZ, 2005) 25 .

- No momento de elaboração ou avaliação de sua documentação, o educador pode se questionar, por exemplo:

- Quando documento com minhas próprias palavras e ações, retrato com fidelidade o que ocorreu com os estudantes?

- A documentação me permite reexaminar coisas que eu não havia notado ou entendido inicialmente?

- A documentação me ajuda a identificar momentos de aprendizagem ou aspectos específicos do contexto de aprendizagem?

- A documentação aponta novas possibilidades para minha prática e para a aprendizagem dos alunos?

- A documentação suscita questões que possam ser debatidas com colegas e estudantes?

- Que outra documentação poderia ser produzida para ampliar esta reflexão?

- Em momentos em que é possível compartilhar a documentação com estudantes e colegas, o educador pode perguntar:

25 Todas as perguntas sugeridas neste item estão disponíveis na homepage do projeto Making Learning Visible. As questões foram traduzidas de forma livre para a língua portuguesa e adaptadas para o contexto em que estão apresentadas no debate da pesquisa. Disponível em: http://www.pz.harvard.edu/projects/making-learning-visible. 
- A documentação está focada na real aprendizagem ou somente em "o que foi feito"?

- A documentação promove o debate e aprofundamento da compreensão sobre algum aspecto específico de aprendizagem?

- A documentação remete a alguma questão em particular sobre um momento de aprendizagem?

- Qual o momento apropriado para compartilhar a documentação com o grupo de estudantes?

As ideias desenvolvidas no âmbito do PZ também alargaram o debate desenvolvido pela abordagem de Reggio Emilia sobre o tipo de documentação que é compartilhada de forma mais ampla - aquela que é exposta em painéis pela escola ou mesmo em espaços externos, em outros contextos (MLV; PZ, 2005; 2006).

Em relação à documentação que precisa ser compartilhada de maneira mais ampla - e não só com estudantes e colegas - as questões sugeridas ao educador são:

- A documentação possui referência suficiente que permita a alguém de fora do contexto visualizar e entender a situação representada?

- A documentação realmente foca na aprendizagem, e não apenas no que foi realizado?

- A documentação foca no processo na mesma medida em que no produto da aprendizagem?

- A documentação comunica claramente os aspectos de aprendizagem que o grupo considera relevantes?

- A documentação contempla diferentes recursos e tipos de registro?

- A documentação possui um título ou tema principal?

- A documentação está apresentada de forma que possibilite a compreensão de quem a visualiza?

- A documentação acrescenta algo ao coletivo e promove discussões sobre as aprendizagens?

Nesta perspectiva, em parceria, investigadores americanos e italianos elaboram uma diferenciação conceitual entre documentação e registro, pontuando que os termos não podem ser tomados como sinônimos ou equivalentes. Os registros produzem sentido apenas quando são produtos de análise e interpretação entre diferentes sujeitos envolvidos no processo educativo; já a documentação, evidencia tanto o processo de aprendizagem quanto o produto de 
determinada vivência (MLV; PZ, 2005; 2006).

Com o objetivo de sistematizar as práticas que ajudam a tornar o pensamento visível, o PZ tem desenvolvido outro projeto, o Visible Thinking $(\mathrm{VT})^{26}$, que pode ser traduzido para o português como "Pensamento Visível". Originalmente, o projeto foi criado pela Lemshaga Akademi, da Suécia, a partir dos anos 2000, como parte de um projeto maior, o Inovating of intelligence. A abordagem se ancora em três práticas: "rotinas de pensamento", documentação do pensamento do aluno e a reflexão provocada pelo educador. A ideia central do projeto gira em torno da sistematização de "rotinas de pensamento" (thinking routines), que são diferentes percursos elaborados para apoiar o desenvolvimento do pensamento dos alunos de diferentes idades, integrados à aprendizagem de conceitos em diferentes áreas do conhecimento.

A iniciativa do projeto busca despertar a consciência sobre aprendizagem em alunos e educadores, provocando-os a identificarem seus "dispositivos de pensamento" (thinking dispositions). No âmbito do projeto, os dispositivos de pensamento são definidos como "hábitos da mente", ou padrões repetidos durante a realização de diferentes atividades, até que esses comportamentos se tornem rotina. É nesse contexto que se estabelece a ideia das "rotinas de pensamento", que, por sua vez, consistem na frequente aplicação de protocolos, principalmente no momento em que se introduz assuntos ou tópicos a um grupo, possibilitando que os alunos aprendam a usar estas rotinas como uma questão de disciplina. Em outras palavras, a ideia é que desde a infância se desenvolva o hábito de se engajar nos padrões de pensamento que as rotinas promovem. A documentação se insere nesta prática como apoio ao educador que, a partir dela, provocará reflexões sobre as aprendizagens dos alunos (Project Zero; Reggio Children, 2014).

Outro projeto que tem se destacado no âmbito do PZ é o Agency Design ${ }^{27}$ (Project Zero; Reggio Children, 2014; Agency By Design; Project Zero, 2020), criado em 2012 e mantido pela Abundance Foundation. Partindo do objetivo de dar visibilidade ao pensamento, o projeto vem desenvolvendo iniciativas junto a escolas e organizações norte americanas, com ênfase na aproximação da educação a outras áreas do conhecimento, como design, engenharia, arquitetura e artes visuais. O projeto vem experimentando o que chama de "pedagogia mão

\footnotetext{
${ }^{26}$ Disponível em: http://www.pz.harvard.edu/projects/visible-thinking.

27 Disponível em: http://www.agencybydesign.org/explore-the-framework.
} 
na massa" (hands-on pedagogy), que incentiva a participação ativa dos alunos na construção e produção artesanal de instrumentos, materiais e recursos visuais que apoiem sua aprendizagem e desenvolvam o pensamento.

Nas experiências quem vem desenvolvendo, o Agency by Design tem provocado educadores a refletir sobre como eles próprios, em parceria com os alunos, podem projetar um conjunto de práticas de documentação que permita o aprimoramento do acompanhamento e avaliação das aprendizagens. Para isso, sugere-se o desenvolvimento de uma "sensibilidade ao design", uma atitude de despertar para a dimensão estética que está construída ou "desenhada" nos espaços em que se vive. Com a sensibilidade ao design, os sujeitos envolvidos no processo educativo compreendem que todos os objetos ou conjuntos de instrumentos que utiliza foram construídos por alguém e que todos podem redesenhar ou recriar designs para modificarem sua realidade.

Um dos objetivos principais da sensibilidade ao design é fornecer subsídios e incentivar os sujeitos a construírem e moldarem a realidade ao seu redor. Com esse desenvolvimento, crianças e adultos têm oportunidade de olhar atentamente e refletir sobre o design de objetos e sistemas, explorar a complexidade do design e entender-se como projetistas de seu contexto. A natureza inter-relacionada destas capacidades pode ser adaptada ao processo de produção de registros e documentação com fotografia, conforme apresentado no diagrama da Figura 2. 


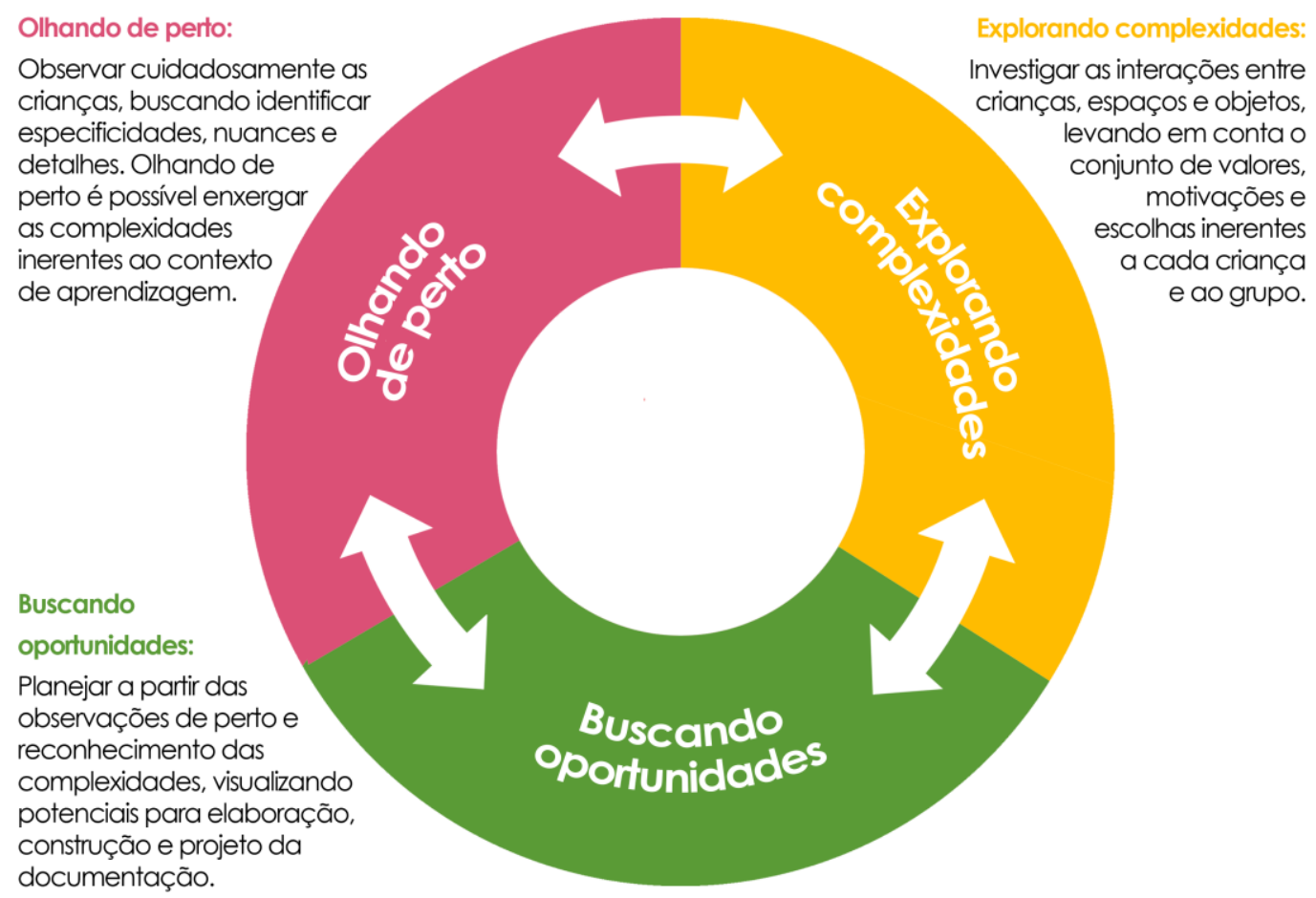

Figura 2 - Projetando a documentação pela "sensibilidade ao design"28 Fonte: Agency by Design/Harvard University (2020), adaptado pela autora.

No trabalho educativo com crianças, propõe-se que a documentação seja projetada em um contexto de interação e inter-relação com o ambiente e entre os indivíduos envolvidos. Na proposta apresentada acima (Figura 2), as etapas propostas pelo Agency by Design - "olhando de perto", "buscando oportunidades" e "explorando complexidades" - são mantidas, mas o foco de cada momento se desloca dos objetos e sistemas para os sujeitos, dando visibilidade às aprendizagens infantis. O círculo evoca a ideia de fluidez e continuidade, sem que uma etapa se sobreponha à outra. Também não há um ponto de partida, indicando que o educador possa seguir os passos de forma cíclica em interação com as crianças.

\footnotetext{
${ }^{28}$ Todo conteúdo produzido e publicizado pelo Agency by Design é protegido por Creative Commons Attribution-NonCommercial 4.0 International License, havendo permissão para: compartilhar - copiar e redistribuir o material em qualquer suporte ou formato; e adaptar - remixar, transformar, e criar a partir do material. A imagem original encontra-se no Anexo $C$ deste documento.
} 


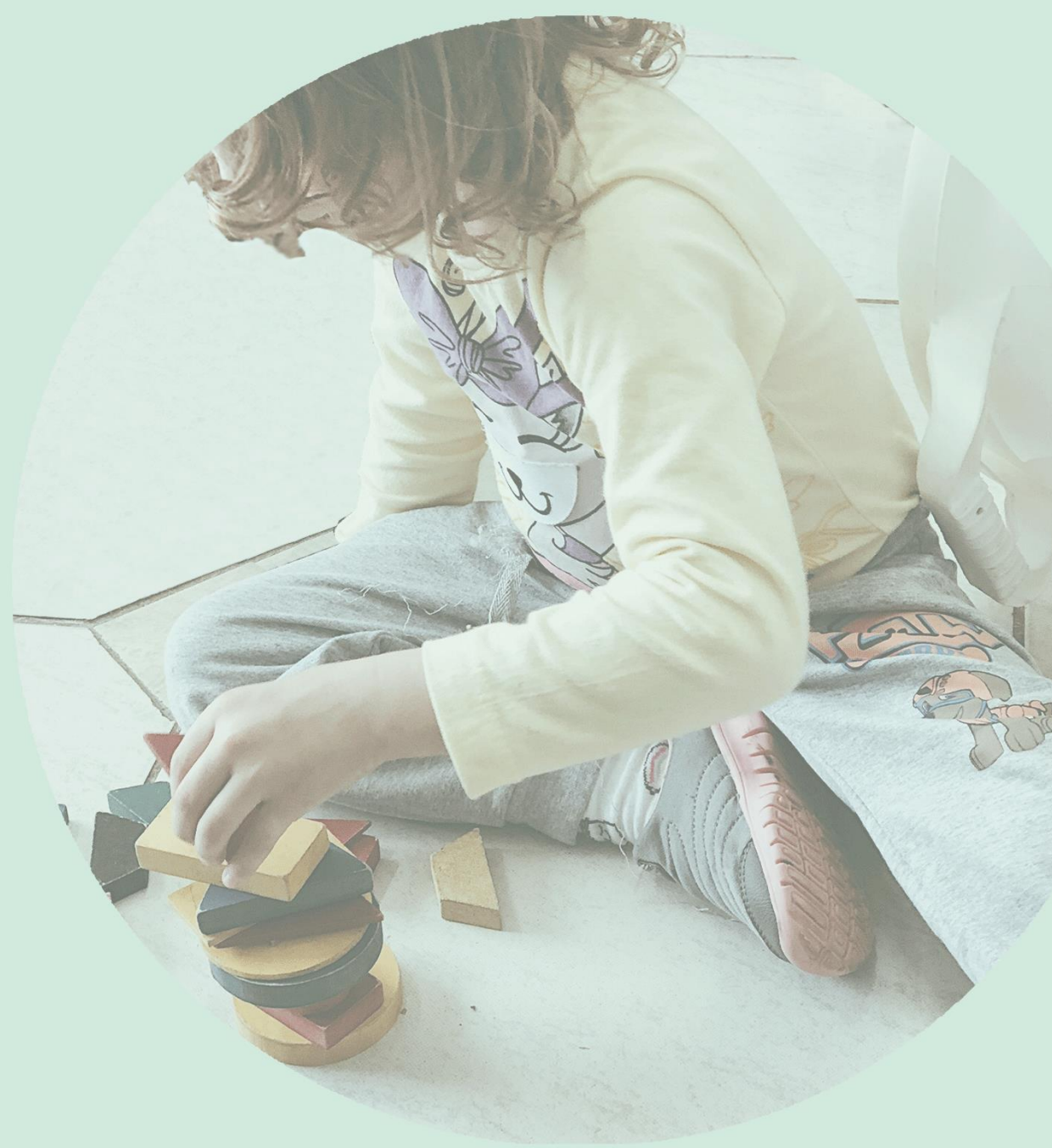

Decidir 


\section{3}

\section{Delimitando o ângulo de visão: a metodologia da pesquisa}

Esta etapa da tese apresenta escolhas, decisões e estratégias metodológicas da pesquisa para imersão no campo empírico - que inicia com uma contextualização da escola selecionada para a realização da pesquisa - e o caminho percorrido para análise dos dados.

\section{1}

\section{Recortes no contexto: o campo de pesquisa}

Considerando a importância de o pesquisador conhecer o contexto que pretende investigar, optou-se por realizar a pesquisa de campo em uma escola de educação infantil da rede municipal de ensino de Erechim, no Rio Grande do Sul - cidade onde trilhei a maior parte de minha trajetória acadêmica e profissional.

Erechim é considerada uma cidade polo da região do Alto Uruguai gaúcho, sendo a segunda cidade mais populosa do norte do estado, com aproximadamente 100.000 habitantes. Foi uma das primeiras cidades brasileiras modernas planejadas, com inspiração em conceitos urbanísticos usados nos traçados de Washington, Paris, Buenos Aires e Belo Horizonte.
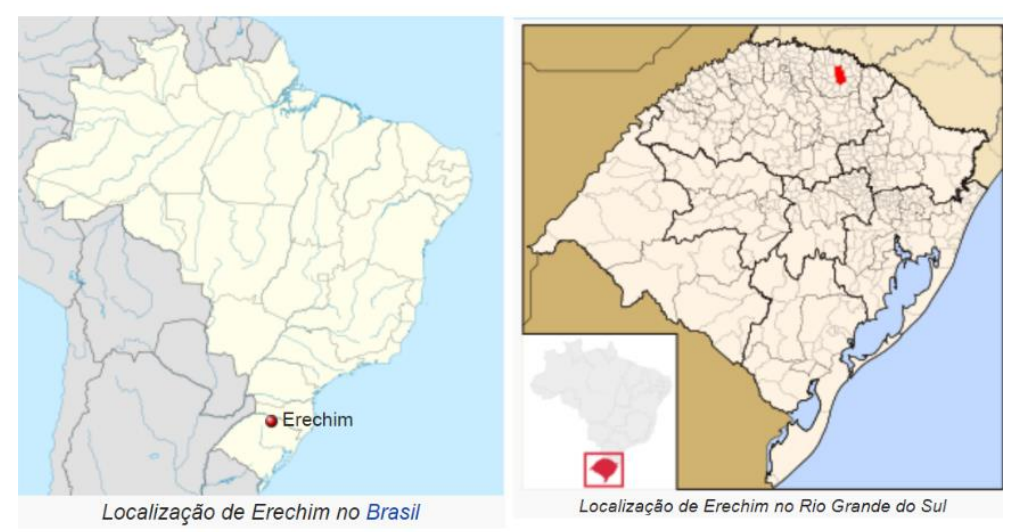

Figura 3 - Localização do Município de Erechim-RS Fonte: Erechim - Wikipédia (2018).

Erechim já foi conhecida como a "Capital do Trigo", devido ao alto volume de grãos produzidos em sua agricultura e como a "Capital do Chimarrão", pela produção de erva-mate da cidade, mas hoje é tida como a "Capital da Amizade", como símbolo da união entre os povos imigrantes que colonizaram a região: alemães, italianos, poloneses e israelitas. Já a origem do nome de Erechim remete 
aos antigos habitantes indígenas da região. Erechim significa "Campo Pequeno", provavelmente porque os campos da região eram cercados por florestas ${ }^{29}$.

\section{Município de Erechim}

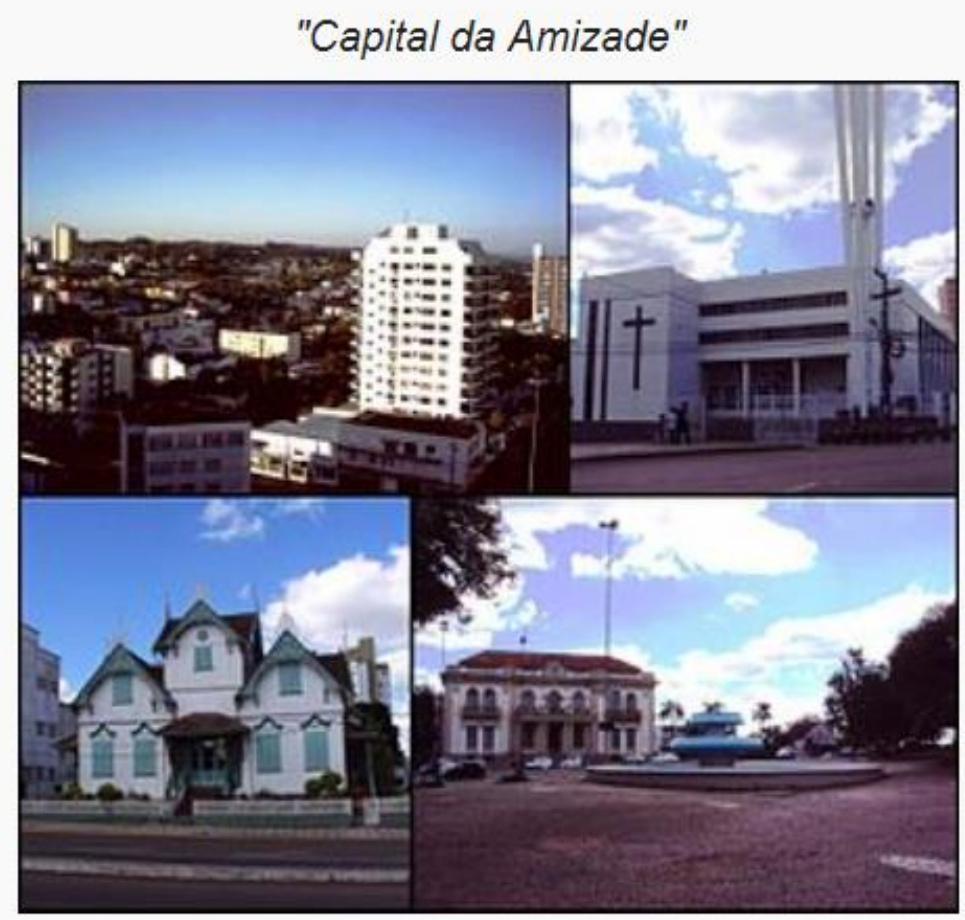

Acima, à esquerda, uma vista parcial da região central da cidade; à direita a catedral de Erechim; abaixo, à esquerda, o Castelinho; e à direita a Praça da Bandeira.

Figura 4 - Erechim: "Capital da Amizade" Fonte: Erechim - Wikipédia (2018).

Selecionou-se como lócus de investigação a Escola Municipal de Educação Infantil Dom João Aloísio Hoffman. Pode-se dizer que esta escolha se deu por uma convergência de interesse pela temática da pesquisa. Durante os meses de junho e julho de 2018, a equipe da escola divulgou em suas redes sociais momentos de formação continuada que tinham ocorrido na escola, que tiveram como foco a reflexão sobre as fotografias que são tiradas pelas professoras. Até esse momento, tinha-se apenas estabelecido alguns critérios para escolha da

${ }^{29}$ Fonte: Prefeitura Municipal de Erechim. Disponível em: <http://www.pmerechim.rs.gov.br/pagina/149/como-tudo-comecou. Acesso em: 05 jul. 2018. 
escola, dentre os quais: que fosse uma escola da rede municipal de ensino e que atendesse exclusivamente à educação infantil; que fosse uma escola com a qual eu não tivesse envolvimento direto ou tido vínculo efetivo; e que a escola já tivesse um interesse mínimo pela temática. Após a constatação de que a referida escola atendia a todos esses critérios, estabeleceu-se um contato prévio e, após uma visita à escola, a equipe manifestou interesse e satisfação em participar desta pesquisa por meio de uma carta assinada pela diretora.

A Escola Municipal de Educação Infantil Dom João Aloísio Hoffman foi inaugurada no dia 12 de novembro de 2005. Está localizada à Rua Santa Bárbara, número 28, no complexo sócio-educativo do Bairro Progresso, que está localizado na região periférica da cidade de Erechim (Figura 5).

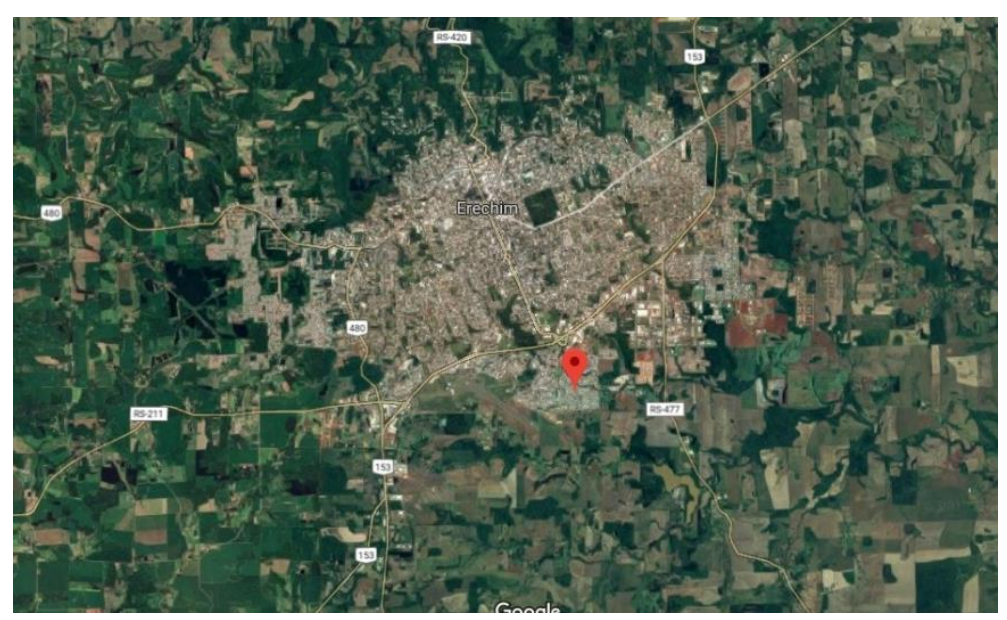

Figura 5 - Localização do Bairro Progresso, Erechim-RS Fonte: Satélite - Google Maps (2018).

Em 2018, a EMEI Dom João A. Hoffman atendia em média a 235 crianças de dois anos completos até cinco anos e onze meses, nos níveis de Maternal I (23 anos), Maternal II (3-4 anos), Pré A (4-5 anos) e Pré B (5-5 anos e 11 meses), no turno da manhã e da tarde. Dessas, em torno de 30 crianças são atendidas em tempo integral, em um prédio vizinho à escola, que pertence à Obra Santa Marta ${ }^{30}$. A escola conta com 16 professoras, seis funcionárias (cozinheiras, auxiliares de limpeza e agente executiva) e quatro auxiliares de educação infantil. Além disso, a escola se propõe a servir de "apoio real e efetivo às crianças e suas famílias,

\footnotetext{
30 Instituição sem fins lucrativos com qual a escola compartilha responsabilidade pelo trabalho pedagógico e gestão administrativa e de recursos, mas que não está vinculada diretamente à prefeitura municipal.
} 
oportunizando um ambiente de aprendizagem seguro e acolhedor, seguindo os princípios fundamentais da educação infantil: educar, cuidar e brincar"31.

Segundo informações fornecidas pela equipe de gestão, parte das famílias das crianças que frequentam a escola encontra-se em situação de vulnerabilidade social. Destas, aproximadamente 73 contam com auxílio do Programa Bolsa Família, conforme Lei no 10.836/2004, tendo acompanhamento de assistentes sociais do Centro de Referência de Assistência Social (CRAS) e das enfermeiras e agentes de saúde da Unidade Básica de Saúde - (UBS) do bairro. Outras famílias possuem carteira de trabalho, com empregos nos setores: industrial, comercial, construção civil, hospitalar e público. Também há um número de famílias que trabalha de forma autônoma, com pequenas empresas, como: borracharias, salões de beleza, lavagem de automóvel, pequeno comércio alimentício e de vestuário, prestação de serviços e reciclagem.

Conforme registram dados da secretaria da escola:

\begin{abstract}
A desigualdade social pode ser evidenciada no bairro em que a escola está inserida, devido a fatores como desestrutura familiar, violência, mudanças repentinas de bairro e cidade, familiar em situação prisional, uso de drogas ou em decorrência dele. Nota-se um crescimento nos índices de violência no bairro, como assaltos e assassinatos envolvendo famílias da escola (PPP, 2018, p. 08).
\end{abstract}

Diante dos fatores citados, a escola também enfrenta casos de infrequência escolar. O trabalho da escola, embasado em uma gestão democrática, participativa e colaborativa, por meio de parcerias com outros segmentos da sociedade civil, como CRAS, Conselho Tutelar e UBS, vem realizando ações para tornar as crianças frequentes, atuando junto às famílias para que compreendam a importância da educação na diminuição das desigualdades sociais. A escola busca também promover ações de integração entre família e escola.

\footnotetext{
31 Todas as informações que compõem essa descrição da escola foram fornecidas pela equipe gestora ou constam no Histórico da Escola Municipal de Educação Infantil Dom João Aloísio Hoffmann - documento elaborado pela gestão 2016-2018 - e no Projeto Político-Pedagógico (PPP, 2018) da escola. Esses documentos estão arquivados na secretaria da própria escola.
} 


\section{2}

\section{Um zoom na escola: a primeira visita}

Mediante convite da diretora, no dia 9 de julho de 2018, realizei uma primeira visita à escola. $\mathrm{Na}$ ocasião, além de apresentar a proposta de pesquisa à equipe de gestão e às professoras, foi possível acompanhar o momento de chegada das crianças do turno da tarde, e percorrer diferentes espaços da escola, fotografando e conversando informalmente com a equipe sobre 0 trabalho que é desenvolvido ${ }^{32}$.

Embora tenha vivido muitos anos em Erechim e tenha circulado por várias escolas do município, esta foi a primeira vez que estive na escola.

Por ser considerado um bairro violento, julguei mais prudente chegar à escola acompanhada pela diretora, que no caminho me deixou a par de alguns aspectos relativos à escola e sobre sua gestão, e me guiou até a sala dos professores (Nota de campo da pesquisadora, julho/2018).
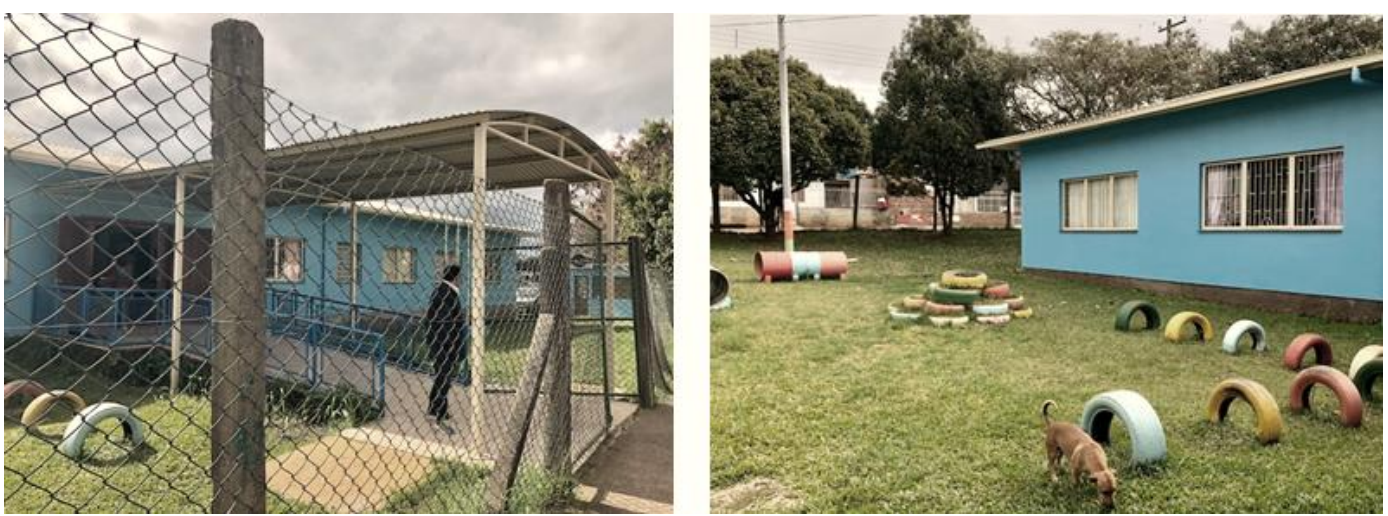

Figura 6 - Prédio da escola

Fonte: Acervo da autora.

Fazia muito frio neste dia - em média $10^{\circ} \mathrm{C}$, e entre os primeiros aspectos que me chamaram atenção, destaco o fato de as crianças chegarem bem agasalhadas à escola: vestindo gorro, botas, luvas e casacos pesados. Não deveria ter sido uma surpresa, afinal estava muito frio, mas percebi que o período distante desse contexto ofuscou um pouco minha visão sobre a realidade do sul do Brasil e de Erechim, especificamente. Embora eu já soubesse que as escolas municipais de Erechim não adotam uniforme escolar obrigatório, naquele dia, de alguma forma, eu imaginava as crianças do bairro chegando à escola de chinelo de dedo, vestindo pouca roupa e sentindo frio. Essa observação pessoal é válida para contextualizar a realidade da escola. Em Erechim, as desigualdades não são tão evidentes. O próprio bairro em que a escola está localizada, considerado de alta periculosidade

\footnotetext{
32 Pelo fato de que ainda não se tinha coletado termos de consentimento de uso de imagem dos sujeitos participantes da pesquisa na ocasião da visita, as fotografias que constam neste item não expõem pessoas, apenas espaços e objetos da escola.
} 
e muita pobreza, em muito se difere do estereótipo que temos sobre a periferia (Nota de campo da pesquisadora, julho/2018).

Ao entrarmos na escola, a diretora indicou um quadro com uma fotografia da vista aérea da escola, feito em homenagem ao centenário de Erechim, comemorado em 30 de abril de 2018. Nele é possível ver um bairro bem arborizado, com casas pouco aglomeradas, certamente o oposto da imagem estereotipada que se tem de um bairro que enfrenta tantas mazelas (Figura 7 .

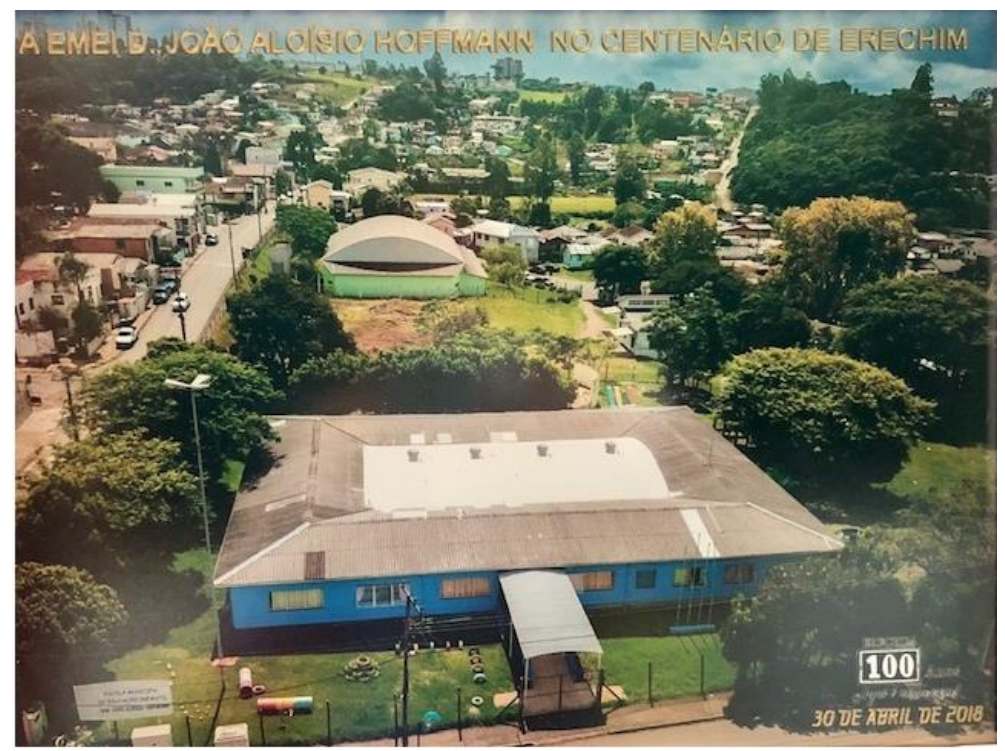

Figura 7 - Vista aérea da escola

Fonte: Acervo da autora.

A arquitetura da escola segue o típico padrão de escolas infantis em que o pátio está localizado ao centro e todas as salas de aula e demais dependências ficam ao redor ${ }^{33}$. Além de sete salas de aula, a escola conta com: laboratório de informática, biblioteca, dois banheiros infantis (sendo um deles adaptado para pessoas com deficiência ou mobilidade reduzida), banheiros de professores e funcionários, cozinha, despensa, lavanderia, refeitório, sala dos professores, sala

\footnotetext{
33 No Brasil, esse modelo de escolas retangulares com um pátio interno tem origem na Primeira República, com os grupos escolares. No início da República, prevaleceu uma atitude otimista em relação à escola, sendo esta vista como "redentora do pecado da ignorância" e "fator de progresso social". Os arquitetos da época dialogavam com os responsáveis pelos caminhos da educação, predominando a "arquitetura neoclássica", caracterizada por "(...) edifício imponente, hall de entrada primoroso, escadarias, eixo simétrico, duas alas, pátio interno (como o dos claustros), corredores internos, janelas verticais grandes e pesadas, acabamento com materiais nobres". A ideia do pátio interno, portanto, é antiga e retoma o modelo dos claustros religiosos. Sendo assim, poderíamos voltar ainda às escolas de caráter jesuíta ou católico, em geral, em que o pátio interno representa vigilância ou até mesmo a separação entre "sagrado" e "profano" (Buffa, 2005).
} 
de coordenação, depósito, secretaria, parque interno com espaço para psicomotricidade, dois parques externos e sala de recursos/Atendimento Educacional Especializado (AEE).

As salas de aula são todas similares. Possuem cartazes pedagógicos que marcam a rotina escolar: na porta de cada sala, ao alcance das crianças, há um mural interativo relacionado com o projeto temático anual da escola e nas paredes das salas há cartazes com calendário, "ajudante do dia”, alfabeto, números, entre outros (Figura 8).
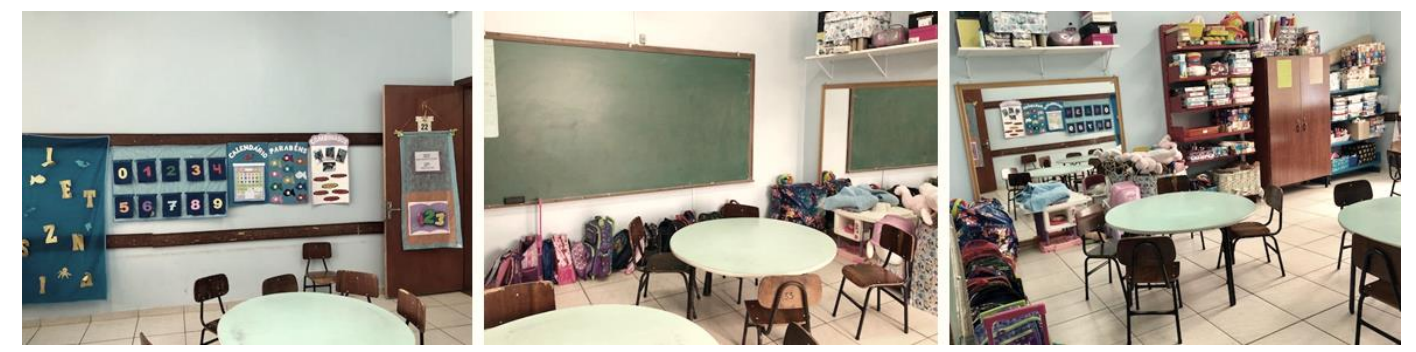

Figura 8 - Sala de aula Fonte: Acervo da autora.

Enquanto percorriam-se os corredores, a diretora chamou atenção para o fato de que havia mesas e cadeiras ao lado de fora das salas de aula, e salientou que essa é uma prática comum entre as professoras. Para variar as estratégias pedagógicas, as professoras costumam movimentar o mobiliário das salas, fazendo um revezamento com mesas e cadeiras, deixando mais espaços livres na sala e dando a possibilidade, por exemplo, de que as crianças desenhem ou pintem utilizando o chão ou as paredes como superfície de apoio.

Em sua trajetória educativa, a escola foi destaque no trabalho desenvolvido na Educação Inclusiva, contando com dois momentos de reconhecimento nacional. Em 2014, esteve entre as dez melhores experiências educacionais inclusivas do Brasil e em 2016, conquistou uma posição entre as cinco melhores experiências educacionais inclusivas do país, no Prêmio "Desenvolvimento Educacional Inclusivo: a escola no enfrentamento das desigualdades sociais", do Ministério da Educação. Na ocasião, a escola recebeu também uma menção honrosa na Câmara de Vereadores de Erechim, em reconhecimento ao trabalho desenvolvido, representada por uma placa fixada no rol de entrada da escola. 

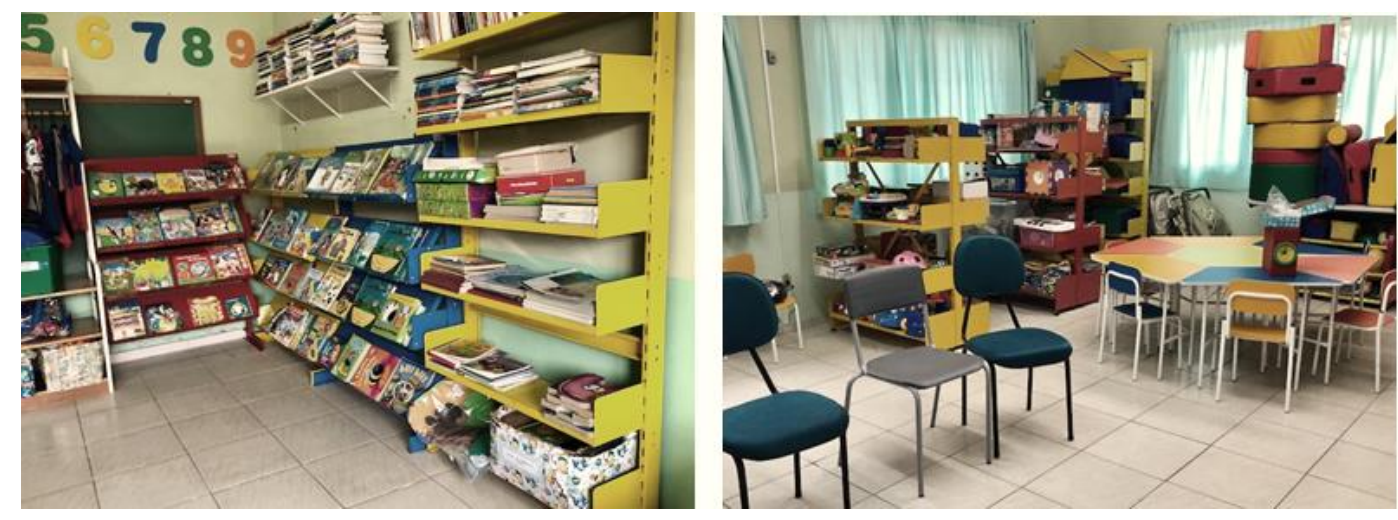

Figura 9 - Biblioteca e Sala de Recursos/AEE Fonte: Acervo da autora.

Na época em que a visita foi realizada (julho de 2018), no contraturno, a escola contava com o trabalho de duas professoras que prestavam Atendimento Educacional Especializado (AEE). Uma delas era responsável pelo atendimento a duas crianças: uma deficiente auditiva e física, de cinco anos de idade e outra com paralisia cerebral, de quatro anos de idade. O trabalho dessa professora acontecia em parceria com as professoras regentes dos grupos em que as duas crianças estudavam e com uma professora bidocente ${ }^{34}$. A outra professora de AEE prestava atendimento de estimulação e observação a uma criança que ainda estava em processo de avaliação sobre suas dificuldades no processo de ensino e aprendizagem e que não possuía um diagnóstico definitivo.

A sala de recursos (fotografia à direita, Figura 9) é a maior sala da escola e, também, costuma ser utilizada com outras finalidades: em propostas com todos os grupos da escola, em reuniões pedagógicas, de planejamento e formação continuada.

A escola dispõe ainda de um Laboratório de Informática Educativa (LIE), com o objetivo de proporcionar às crianças e professoras, aprendizagem e construção do conhecimento com o uso de tecnologias educativas (Figura 10). Os grupos visitam o laboratório semanalmente para utilização dos computadores, que dispõem de diferentes vivências e jogos infantis educativos. Conforme pontuado pela diretora da escola, as professoras tinham o cuidado de realizar um trabalho introdutório ao uso efetivo dos computadores, em especial com as crianças

\footnotetext{
${ }^{34}$ Na perspectiva da Educação Inclusiva, existe o trabalho de Bidocência, que se caracteriza pela atuação de duas professoras em um mesmo grupo, quando há criança deficiente, incapaz de ter independência e autonomia de vida, como: caminhar, alimentar-se e controle dos esfíncteres (PPP da Escola, 2018, p. 19).
} 
menores, de dois e três anos de idade (Maternal I). Fazia parte deste trabalho de preparação, a brincadeira com sucatas tecnológicas: carcaças de monitores de vídeo, teclados de computador e mouses que não funcionam mais (ou que estão defasados), que ficavam disponíveis em uma caixa grande de papelão no próprio laboratório. O laboratório também era equipado com projetor de multimídia e almofadas, podendo ser utilizado pelas professoras para exibir filmes e outras produções audiovisuais.

A manutenção do laboratório era realizada por técnicos de informática, vinculados ao Departamento de Informática Educativa da Secretaria Municipal de Educação - SMED/ DIE.

O termo Informática Educativa refere-se:

[...] ao uso do computador e suas ferramentas no ambiente escolar, um recurso pedagógico a ser utilizado como facilitador da inclusão escolar e social, que incentiva a descoberta de informações e a construção do conhecimento tanto do estudante como do professor (PPP da Escola, 2018, p. 18).

Com o PROUCE - Programa Um Computador por Educador, os professores do município, ao serem efetivados, recebiam um notebook, que podia ser utilizado tanto para uso pessoal quanto em diferentes atividades que compõem a organização do trabalho docente. Por intermédio do Núcleo de Tecnologia Educacional Municipal (NTM), os professores participavam de cursos de formação continuada em tecnologia educacional, como os cursos do Prolnfo - Programa Nacional de Tecnologia Educacional.
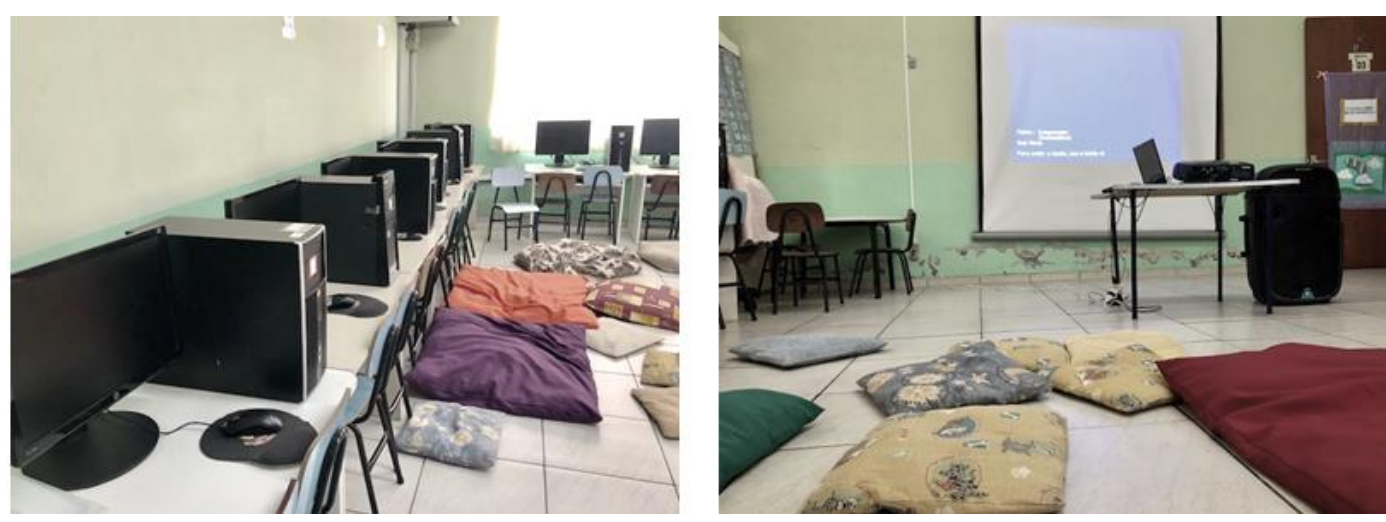

Figura 10 - Laboratório de Informática Fonte: Acervo da autora. 
No projeto arquitetônico original da escola, o pátio interno ficava ao ar livre, mas fora coberto por uma antiga gestão da escola, em virtude das condições climáticas da região. Com o pátio coberto, novos espaços foram adaptados e são utilizados no trabalho desenvolvido pela escola. É nesse espaço que são realizadas reuniões pedagógicas com os pais e responsáveis e também onde as professoras costumam expor as propostas realizadas com as crianças e fotografias por elas tiradas (Figura 11).
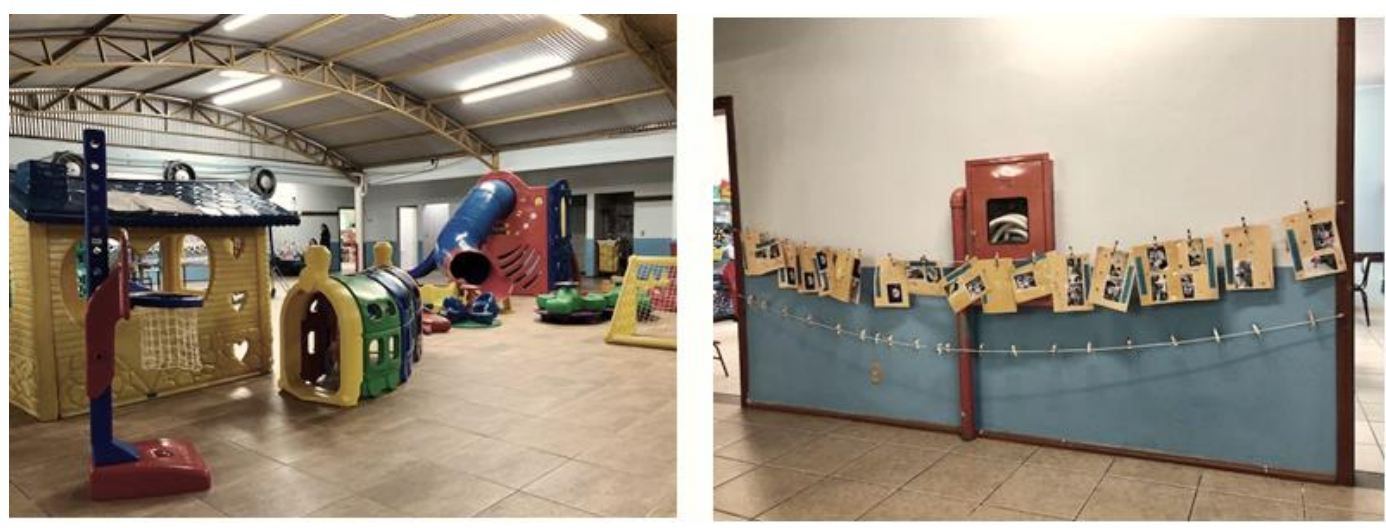

Figura 11 - Pátio interno Fonte: Acervo da autora.

No dia da primeira visita à escola, as fotografias de um dos grupos estavam expostas coladas em folhas coloridas, penduradas em um varal de barbante ao alcance das crianças (fotografia à direita, Figura 11). Chegando mais perto, foi possível identificar que cada folha pertencia a uma criança; tinha duas ou três fotos coladas; e havia um desenho da criança preenchendo o restante do espaço da folha. Provavelmente, essas folhas fariam parte do portfólio individual de cada criança. Reconheceu-se nesta exposição uma primeira amostra do trabalho de documentação que a escola já realizava, embora até aquele momento não se tivesse abordado diretamente o tema com os profissionais da escola.

$O$ passeio pela escola culminou com uma conversa informal com as integrantes da gestão, na sala da coordenação. Embora não houvesse uma estrutura rígida de perguntas para guiar essa conversa, havia intenção de compreender que percursos a escola já vinha trilhando a respeito da produção de registros com a utilização de fotografias e qual a familiaridade com o tema.

Identificou-se, a partir do relato da coordenadora pedagógica, que a escola vinha pensando em inúmeras formas de incluir a fotografia de forma sistematizada em sua documentação. Sinalizou que já havia uma breve menção a esse aspecto 
no Projeto Político-Pedagógico de 2018. Além disso, a própria coordenadora vinha propondo reflexões sobre fotografia e sobre 0 ato de fotografar em reuniões pedagógicas de formação continuada, conforme tinha-se conhecimento pela divulgação nas redes sociais. Nessas reuniões, as professoras vinham problematizando, principalmente, a forma que fotografam e vinham se dando conta de que é possível produzir fotos que não coibissem a espontaneidade das crianças. A orientação entre o grupo era evitar poses combinadas e não interromper vivências para fotografar.
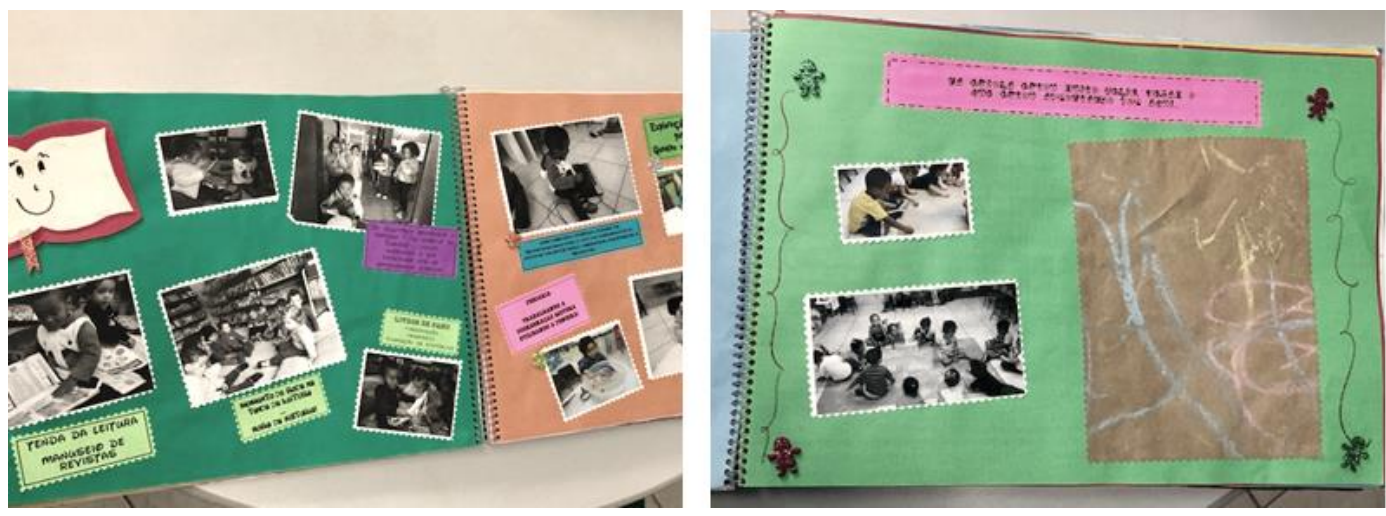

Figura 12 - Portfólio do aluno Fonte: Acervo da autora.

Outra forma de documentação apresentada pela equipe gestora foi o portfólio de uma criança do Maternal I. Nele, muitos desenhos e produções da criança vinham acompanhados por fotografias e identificação escrita da proposta (Figura 12). Essas coletâneas eram encadernadas e enviadas para as famílias ao final de cada semestre. Conforme já abordado, as produções das crianças são parte de importante na composição da documentação que será comunicada e compartilhada. Quando esse tipo de documentação está acompanhado de outros registros, de comentários dos professores ou das próprias crianças, pode evidenciar aspectos não apenas do produto final, mas de todo processo que compõe as vivências e o fazer pedagógico (Ostetto, 2017).

Ao final da conversa, a coordenadora apresentou os álbuns de fotografia da escola, que são organizados anualmente e guardados na secretaria (Figura 13). Cada álbum é montado em uma pasta com plásticos, com fotos e outros registros coletados durante o ano pela equipe gestora, secretaria e professoras. Nesses álbuns também eram anexados recortes de jornal e notícias da imprensa local, divulgando o trabalho da escola. A montagem desses álbuns é uma prática antiga 
na escola, que perdura desde o primeiro ano de seu funcionamento - 2005.

O reencontro com os álbuns de fotografia tornou possível que a equipe relembrasse momentos fotografados - eventos festivos, "atividades especiais", premiações, antigos alunos e colegas de trabalho - muitos dos quais já não estão mais na escola. Outro fato comentado foi a respeito da qualidade das fotos, que inicialmente eram feitas com câmera fotográfica analógica e reveladas em estúdio, evoluindo para diferentes câmeras digitais e, hoje, feitas quase sempre com aparelho celular e impressas em tinta colorida na própria escola. O comentário entre elas era que precisavam proporcionar mais momentos como esse, de recuperação da memória da escola. Discutiu-se, até, sobre formas de tornar esses álbuns acessíveis também para as crianças e para a comunidade escolar, como um todo.
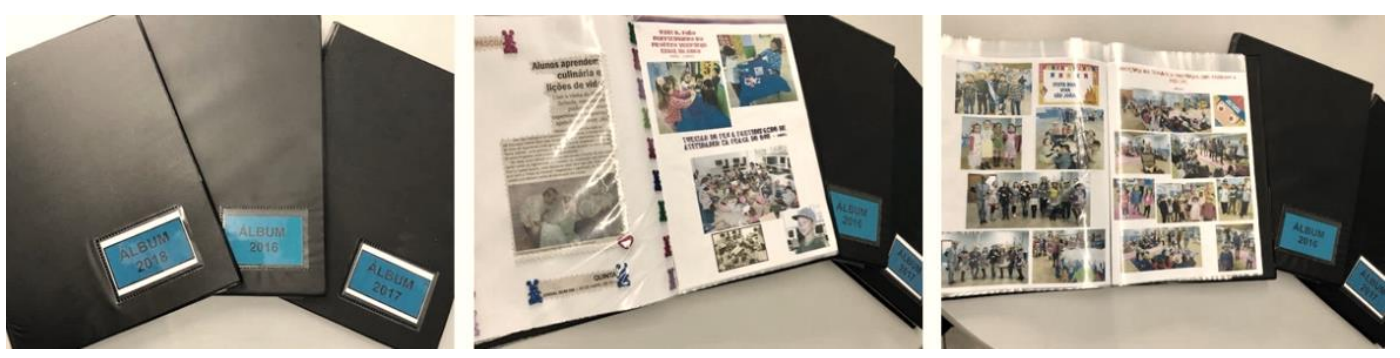

Figura 13 - Álbuns de fotografia e outros registros Fonte: Acervo da autora.

É importante ressaltar que essa primeira visita à escola não teve como propósito gerar dados para a pesquisa. O foco central esteve em estabelecer um primeiro diálogo com a equipe da escola, com o objetivo, principalmente, de aproximar o universo investigativo acadêmico da prática da escola. Ainda assim, a visita deixou vários indícios de que a escola já vinha pensando sobre os registros e a documentação com fotografia em uma dimensão formativa e comunicativa - 0 que indicava que a continuidade do processo de realização da pesquisa poderia ser um trabalho de cooperação e complementaridade. Este primeiro contato com a escola contribuiu para que se fizessem escolhas metodológicas importantes, que delinearam o design para a pesquisa de campo. 


\section{3}

\section{Projetando o design para imersão no campo de pesquisa}

Para a realização da pesquisa, optou-se por uma abordagem metodológica qualitativa, sustentada em Gatti e André (2010, p. 30), que a consideram uma "modalidade investigativa que se consolidou para responder ao desafio da compreensão dos aspectos formadores/formantes do humano, de suas relações e construções culturais, em suas dimensões grupais, comunitárias ou pessoais".

Inicialmente, a pesquisa teve caráter exploratório e, progressivamente, assumiu contorno participante, a partir da interação com o contexto investigado. Este caráter participativo implica a necessidade de uma definição clara a respeito de sua tipologia dentro de um espectro de possibilidades metodológicas.

É comum em discussões no campo das ciências sociais, inclusive entre estudiosos, que se questione sore a definição das modalidades de pesquisa-ação e pesquisa participante. Em alguns contextos as duas modalidades se apresentam como sinônimos. Para Soares e Ferreira (2006), a expressão "pesquisa participante" possui equivalência a outras, como: pesquisa-ação, pesquisa participativa, investiga-ação, investigação participativa, investigação militante, auto-senso, estudo-ação, pesquisa-confronto, investigação alternativa, pesquisa popular, pesquisa ativa, intervenção sociológica, pesquisa dos trabalhadores, enquete-participação, entre outras. Contudo, outras perspectivas têm marcado diferenças significativas entre essas tipologias metodológicas.

A pesquisa participante tem se consolidado como um tipo de pesquisa que torna possível o atendimento às necessidades de classes mais empobrecidas em estruturas sociais contemporâneas - populações que compreendem operários, camponeses, agricultores e índios - tendo em vista suas aspirações e potencialidades de conhecer e agir (Brandão, 1998).

Em contrapartida, a pesquisa-ação é apresentada por Thiollent (2011, p. 14) como

[...] um tipo de pesquisa social com base empírica que é concebida e realizada em estreita associação com uma ação ou com a resolução de um problema coletivo e no qual os pesquisadores e os participantes representativos da situação ou do problema estão envolvidos do modo operativo ou participativo.

No campo da educação, a pesquisa-ação vem se estruturando como uma tentativa sistemática e empiricamente fundamentada de aprimorar a prática, sendo utilizada em pesquisas educacionais que privilegiam o envolvimento entre 
o pesquisador e o pesquisado (Demo, 2005; Tripp, 2005). Assim, esta pesquisa se filia a à pesquisa-ação, quando se propõe a investigar os processos de registro e documentação pela linguagem fotográfica no contexto da prática, interagindo com os atores sociais da escola. Destacam-se outras características da pesquisaação que a aproximam da proposta desta investigação:

-Toda pesquisa-ação é do tipo participativa;

- O pesquisador não é pesquisado;

-Supõe uma forma de ação planejada de caráter social, educacional, técnico ou outro;

- O pesquisador tem uma ação destinada a resolver o problema em questão;

- O pesquisador é que se apropria mais intensamente dos dados;

- Pesquisador deve ter um alto grau de análise, de moderação, de interpretação e de animação, dominar técnicas de dinâmicas de grupo. (Felcher; Ferreira; Folmer, 2017, P. 06)

O envolvimento das crianças foi incorporado à metodologia da pesquisaação a partir dos contributos da Sociologia da Infância (Sarmento; Pinto, 1997; Soares; Sarmento; Tomás, 2005; Sarmento, 2008; Corsaro, 2009; 2011), que entende as crianças como atores sociais, com competência para interpretar as realidades sociais em que estão inseridos. Nas ciências sociais, as metodologias participativas com crianças têm se configurado como um recurso metodológico importante para o alcance de transformação social e extensão de direitos, reconhecendo as crianças como atuantes na construção do conhecimento e não apenas objeto de pesquisa.

A imersão na escola se deu por aproximadamente oito meses - entre 2018 e 2019, com a realização de atividades concomitantes: A. Observação participativa; B. Diálogos transversais (entrevistas com as educadoras; participação em reuniões pedagógicas e conversas com as crianças) (Figura 14).
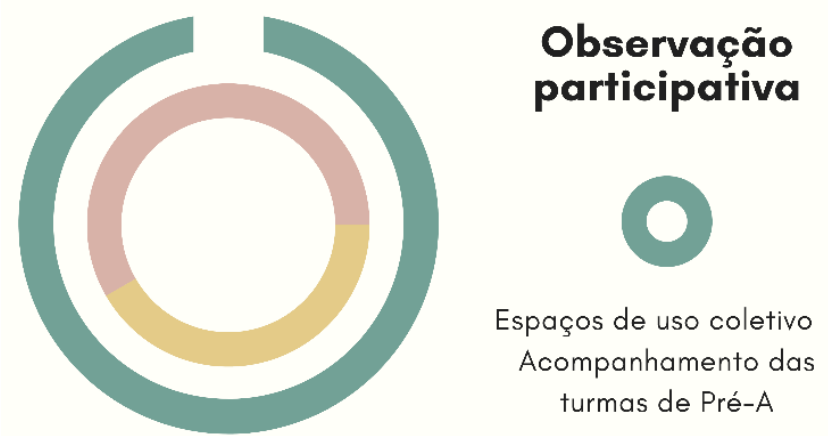

Figura 14 - Desenho da Pesquisa de campo Fonte: Elaborado pela autora.

\section{Diálogos transversais}

Entrevistas

Reuniões pedagógicas 


\section{A. Observação participativa}

Consistiu no acompanhamento das atividades realizadas na escola, cumprindo um cronograma que previa em torno de seis horas diárias de permanência no campo, por pelo menos dois dias na semana, durante aproximadamente oito meses. A observação participativa foi realizada em duas etapas: 1) 2018 (outubro, novembro e dezembro) - observação dos espaços coletivos da escola; 2) 2019 (abril, maio, junho, julho e agosto) - acompanhamento do cotidiano de quatro grupos de Pré-A.

Considera-se que a observação tenha sido de caráter participativo, pensando na postura que assumi, como pesquisadora, em interação com educadoras e crianças, estando atenta aos sentidos do que se observa. Estive aberta ao diálogo junto às educadoras e crianças a todo momento, com isso, trabalhou-se com um cronograma aberto, construído junto dos participantes, prevendo modificações e adaptações de acordo com as atividades da escola e com situações suscitadas a partir do contexto.

Com base em prerrogativas da Sociologia da Infância ${ }^{35}$, levaram-se em consideração aspectos indicados por Soares, Sarmento e Tomás (2005), para a organização da observação com participação efetiva das crianças:

A. Valorização da voz e ação das crianças - garantia de que o envolvimento das crianças na pesquisa não é de pseudo-participação, "sob pena de o processo de investigação estar comprometido desde as etapas iniciais" (p. 09). Para acautelar exclusões eticamente inaceitáveis em critérios de competência, étnicos ou de estatuto social, propus-me a conhecer as crianças a partir delas próprias e não somente pela fala e apresentação dos adultos da escola.

B. Consentimento informado - "Informação dada à criança acerca da investigação em causa e o seu consentimento para participar na mesma" (p. 09). Além do termo de consentimento assinado pelos responsáveis de cada criança ${ }^{36}$, assegurou-se às crianças sua participação livre e voluntária, por meio de um Termo de Assentimento Livre e Esclarecido (Apêndice $A$ ), ilustrado e adaptado a uma linguagem elucidativa às

\footnotetext{
35 Sarmento; Pinto, 1997; Soares; Sarmento; Tomás, 2005; Sarmento, 2008; Corsaro, 2011.

${ }^{36} \mathrm{Em} \mathrm{2019}$, quando a pesquisa se direciona aos grupos de Pré-A, as crianças foram autorizadas a participarem da pesquisa mediante assinatura dos responsáveis no Termo de Consentimento Livre e Esclarecido, cujo modelo está disponível nos Apêndices (Apêndice B).
} 
crianças. O documento foi apresentado aos quatro grupos por suas educadoras, orientadas por mim, por considerar importante a confiança das crianças nos adultos de referência. Além disso, levando em conta que as crianças participantes não eram alfabetizadas, o texto que acompanha as imagens foi apresentado oralmente, semelhante à narração de uma história.

C. Consideração de estratégias e recursos metodológicos plurais e criativos - Utilização de múltiplos recursos metodológicos, "que permitam tornar audíveis as vozes de todas as crianças, mesmo (ou sobretudo) aquelas cujo silenciamento forçado pela norma social é maior", como é o caso de crianças bem pequenas (p. 10). Entre as estratégias metodológicas mais utilizadas com as crianças na pesquisa, destaca-se o diálogo conduzido por imagens, rodas de conversa, fotografia e gravação de áudio para produção de dados e, também, momentos em que as próprias crianças produzissem registros e manuseassem os equipamentos fotográficos e digitais.

Além da coleta de registros diferenciados, a observação previa avaliação junto às crianças, o que permitiria "confrontar pontos de vista e construir um conhecimento reflexivamente sustentado na análise de práticas sociais e interações" (Soares; Sarmento; Tomás, 2005, p. 68).

A observação participativa foi norteada pelas seguintes questões ${ }^{37}$ :

- A que processos se escolhe dar visibilidade?

- Quem tira as fotografias?

- Que criança se quer comunicar?

- Como e quando se fotografa?

- O que se pretende comunicar com as fotografias?

- E os adultos, onde estão?

Estas perguntas levam em conta a validade, viabilidade e efetividade de construção de parceria estabelecida com a escola, visando implementar na pesquisa-ação, um percurso que permitisse compreender a utilização da fotografia na construção de um escopo documental das vivências infantis e dos processos

${ }^{37}$ As questões norteadoras possuem referência em Malavasi \& Zoccatelli (2019). 
de aprendizagem. As questões norteadoras não foram respondidas em sequência durante a observação, tendo como referência a proposta de "sensibilidade ao design", na qual o investigador assume uma postura atenta para o que está projetado no ambiente que o cerca, deixando que as circunstâncias da prática o conduzam à investigação. Observar sob esse pretexto implica continuamente em: "olhar de perto", "buscar oportunidades" e "explorar as complexidades" (Project Zero, 2020).

\section{B. Diálogos transversais}

Os diálogos estabelecidos de forma transversal com adultos e crianças durante a observação participativa, tornaram-se dados importantes na pesquisa. Além de tomar notas por escrito a partir das interações no campo, acompanhouse reuniões, tendo como referência a abordagem de formação em contexto (Oliveira-Formosinho; Kishimoto, 2002; Oliveira-Formosinho; Formosinho, 2001), buscando promover reflexões a partir da partilha de experiências vividas pelas educadoras durante a pesquisa. $O$ trabalho realizado junto às educadoras foi referenciado na concepção de educador-investigador, visando a possibilidade de as educadoras aprimorem sua prática pela instrumentalização do ato de fotografar e interpretar as imagens (Moran, 2009; Malavasi; Zoccatelli, 2019).

Também foram realizadas entrevistas semiestruturadas com as integrantes da equipe de gestão da escola - em 2018 - e com as professoras responsáveis pelos grupos de Pré-A - em 2019.38 O Quadro 3 apresenta as questões norteadoras que balizaram a entrevista feita as integrantes da equipe de gestão. As questões foram organizadas a partir de duas dimensões, a pedagógica e a subjetiva. A dimensão pedagógica engloba situações que competem às atividades profissionais correspondentes à função que cada uma das participantes exerce na gestão da escola. Já a dimensão subjetiva, compreende aspectos de cunho pessoal e subjetivo, no que tange ao ato de fotografar, documentar, bem como às expectativas da entrevistada em relação à continuidade da pesquisa.

\footnotetext{
38 As educadoras com as quais manteve-se diálogo durante a pesquisa - de 2018 a 2019 formalizaram sua participação na pesquisa por meio de um Termo de Consentimento e Livre Esclarecido (Apêndice C).
} 
Roteiro de entrevista | Equipe de gestão

\begin{tabular}{ll}
\multicolumn{1}{c}{ Roteiro de entrevista | Equipe de gestão } \\
\hline Dimensão & \multicolumn{1}{c}{ Questão norteadora } \\
& $\begin{array}{l}\text { 1. Qual a sua função na escola e como é sua interação com crianças, } \\
\text { professoras, funcionários e comunidade escolar? } \\
\text { 2. O que você sabe sobre documentação pedagógica, utiliza esse termo em seu } \\
\text { trabalho? } \\
\text { 3. Em sua função, de que forma orienta as professoras para produção de } \\
\text { registros dos processos de aprendizagem das crianças? } \\
\text { 4. Em sua função, você também produz registros? De que tipo, fotográfico? De } \\
\text { que forma esses registros contribuem com o seu trabalho? } \\
\text { 5. Existe algum cuidado em relação às fotos que são produzidas? } \\
\text { 6. Como as fotos produzidas são armazenadas/descartadas? } \\
\begin{array}{l}\text { 7. Aescola já viveu alguma situação conflituosa em relação às fotografias que } \\
\text { são produzidas e divulgadas? }\end{array} \\
\text { 8. Qual o seu envolvimento pessoal e familiaridade com a fotografia? } \\
\text { 9. Há diferença na forma que você fotografa em situações particulares e na } \\
\text { escola? }\end{array}$ \\
10. Quais as suas expectativas em relação à pesquisa? \\
\hline subjetiva
\end{tabular}

Quadro 3 - Roteiro de entrevista| Equipe de gestão

Fonte: Elaborado pela autora.

A primeira etapa de entrevistas ocorreu ao início da imersão na escola, entre outubro e novembro de 2018, junto à equipe de gestão. A ideia era ouvir e dialogar com as profissionais sem que a pesquisa já tivesse em andamento a mais tempo e pudesse influenciar suas respostas. Com os dados sobre as expectativas das gestoras em relação à continuidade da pesquisa foi possível estabelecer diretrizes que orientaram os próximos passos da observação participativa.

O Quadro 4 corresponde ao roteiro de entrevista aplicado junto às professoras responsáveis pelos quatro grupos de Pré-A, em 2019. A organização das questões por dimensões temáticas segue a mesma referência da entrevista feita com a equipe gestão - dimensão pedagógica e dimensão subjetiva, mas as perguntas foram direcionadas às propostas desenvolvidas em atuação com as crianças de seus grupos. 


\section{Roteiro de entrevista | Professoras}

Dimensão
1. Você poderia contar um pouco como é sua interação com crianças, pais e
comunidade escolar?
2. O que você sabe sobre documentação pedagógica, utiliza esse termo em seu
trabalho?
3. Como professora, você recebe alguma orientação para produção de registros
dos processos de aprendizagem das crianças?
Pedagógica Que tipos de registro você produz? Costuma fotografar situações de
aprendizagem das crianças?
5. Existe algum cuidado em relação às fotos que são produzidas?
6. Como as fotos produzidas são armazenadas/descartadas?
7. Você já viveu alguma situação conflituosa em relação às fotografias que são
produzidas e divulgadas?
8. Qual o seu envolvimento pessoal e familiaridade com a fotografia?
9. Há diferença na forma que você fotografa em situações particulares e na
escola?
10. Em que você pensa quando está fotografando?

Quadro 4 - Roteiro de entrevista/ Professoras

Fonte: Elaborado pela autora.

Os roteiros de entrevista (Quadro 3 e Quadro 4) foram flexibilizados durante o contexto de aplicação, possibilitando que as participantes incluíssem outras questões suscitadas espontaneamente sobre suas vivências e opiniões, a partir dos temas abordados em cada questão.

Todos os diálogos produzidos nas entrevistas foram gravados em arquivos de áudio, transcritos e analisados em etapa posterior a esta. Nas transcrições, optou-se por identificar as participantes pelo primeiro nome, tendo sido uma decisão conjunta e consentida mediante assinatura nos devidos termos que garantem a ética de cientificidade da pesquisa. 


\title{
3.4
}

\section{Contextualizando o percurso da pesquisa-ação}

As escolas vinculadas à Secretaria Municipal de Educação de Erechim (SMED), em consonância com as políticas educacionais brasileiras, vivenciaram em 2018 e 2019 um processo de reformulação do currículo de creches e préescolas, com a implementação da Base Nacional Comum Curricular para Educação Infantil (Brasil, 2017). A proposta da base evidencia a centralidade da documentação pedagógica na educação infantil, sinalizando a importância de uma escuta sensível e observação atenta das crianças e, com isso, a produção sistematizada e intencional de diferentes tipos de registros: escritos, de áudio ou visuais. Em paralelo ao processo de implementação da BNCC, a EMEI Dom João A. Hoffmann, desde 2018, vinha promovendo formações pedagógicas sobre as fotografias produzidas pelas educadoras, o que as estimulava a refletir sobre seu olhar para a infância enquanto fotógrafas. Foi neste cenário, de transformações e plena discussão curricular, que iniciou o percurso de observação. Registrei em meu diário de campo da pesquisa, as primeiras percepções e emoções suscitadas ao iniciar a imersão na escola em meio a latência dessas mudanças em relação ao currículo e a necessidade de adaptação da metodologia para observação participativa:

\begin{abstract}
Percebo que na escola a fotografia não é novidade. Aliás, pretensão da jovem pesquisadora supor que chegaria no campo de pesquisa cheia de ideias novas e faria uma revolução na prática das educadoras. Não sei se eu seria tão audaciosa, mas o fato é que a escola, não só vem discutindo a fotografia com as professoras, como já está realizando propostas usando a fotografia com as crianças. Uma ideia que eu considerava preciosa seria a de ajudar as professoras a planejarem momentos em que as próprias crianças fotografassem, mas isso também já está sendo feito. A proposta é de que as crianças fotografem seus espaços preferidos da escola. As professoras fizeram uma espécie de triagem, perguntando às crianças sobre quais os seus espaços favoritos da escola, para, a partir disso, organizarem pequenos grupos e saírem da sala para fotografar. Volto à estaca zero e decido, com um pouco mais de humildade, traçar um percurso de observação que me permita acompanhar esses momentos em que as crianças fotografam e os usos dados à fotografia nos espaços de uso coletivo da escola, mas sem interferir na maneira com que essas vivências já vêm acontecendo (Nota de campo da pesquisadora, outubro/2018).
\end{abstract}

A proposta para imersão na escola foi apresentada ao grupo de educadoras em outubro de 2018. Em parceria com a equipe, elaborou-se um cronograma para condução das vivências propostas (observação participativa e diálogos transversais). Percebeu-se pelos comentários da equipe que havia uma expectativa de que, com uma pesquisa que abordaria o tema da fotografia 
acontecendo na escola, as educadoras teriam um ganho técnico, pois seria uma oportunidade de aprimorarem suas habilidades fotográficas.

"Finalmente vou aprender a tirar foto!" esteve entre os comentários mais ouvidos nesta etapa inicial. Foi necessário ponderar com o grupo que, embora este também fosse um tópico relevante à pesquisa, o foco estaria na construção de narrativas dos processos investigativos vividos no cotidiano, em compreender como cada uma conduzia a fotografia para documentar as aprendizagens e vivências das crianças. Além disso, meu conhecimento técnico sobre fotografia possivelmente era semelhante ao delas, portanto teríamos de aprender e aprimorar os conhecimentos para a linguagem fotográfica juntas, em parceria.

Acordou-se com o grupo quais seriam os dias de observação em cada ambiente de uso coletivo da escola, pois seria importante que a equipe toda soubesse onde eu estaria em cada momento de observação, para que não houvesse surpresa, caso me encontrassem em um ambiente da escola enquanto conduziam determinada vivência com as crianças.

\section{ETAPA I - Observação dos espaços de uso coletivo (2018)}

Em 2018, a observação participativa teve como foco os espaços coletivos da escola, seguindo o seguinte roteiro: saguão de entrada/recepção, pátio interno da escola, cozinha, refeitório, banheiros de uso das crianças e parque externo. Cada ambiente foi avaliado por um ou dois dias, em segundas ou terças-feiras, nos meses de outubro, novembro ou dezembro, conforme um cronograma organizado com a equipe da escola.

Nesta etapa de observação, procurava me colocar em um dos cantos do ambiente, com visão privilegiada, sentada em uma cadeira ou banco disponível (ou de pé, quando não havia lugar para se sentar). Buscava-se, compreender a dinâmica de uso daquele espaço pelos grupos de crianças e suas professoras ou por outros adultos que frequentavam a escola. Além disso, a todo momento tentava-se identificar se aquele espaço era registrado com fotografia pelas professoras ou pela equipe gestora e/ou, também, se o espaço servia como expositor para as fotografias feitas pela equipe.

Os ambientes de uso coletivo da escola foram classificados a partir da adaptação de parâmetros que vêm sendo utilizados para qualificação dos espaços públicos, desenvolvidos pela ONG Project for Public Spaces (PPS) (Heemann; 
Caiuby, 201-) $)^{39}$.

Para avaliar os espaços da escola em observação, utilizou-se como critérios dois atributos principais: a) usos e atividades: oferta de atividades e formas de as pessoas usarem o espaço - quando não há nada pensado para determinado espaço, pode significar que ele não está sendo bem utilizado; b) sociabilidade: espaço de encontro e interação entre as pessoas - o espaço que permite interação confortável tende a gerar forte senso de pertencimento (ONG PPS/Heemann; Caiuby, 201-).

Ao chegar em cada ambiente, procurei interferir o mínimo possível na rotina dos grupos, porém, ao se familiarizarem com sua presença, as crianças passaram a se aproximar e fazer perguntas: "Por que você só fica escrevendo nesse caderninho? O que você tá escrevendo? Ontem eu não te vi. Quer tirar uma foto de mim?".

Com estas interações nos espaços de uso coletivo, foi possível compreender importantes aspectos sobre o funcionamento da escola:

- tempo de uso dos grupos em cada ambiente;

- apropriação de determinados espaços pelas crianças e quais as suas preferências;

- preocupações e cuidados das professoras, auxiliares e demais profissionais da escola, de acordo com os materiais disponíveis no ambiente;

- semelhanças e diferenças na forma de cada professora conduzir as crianças ao ambiente - algumas professoras levavam as crianças em fila, outras deixavam as crianças irem sozinhas, em pequenos grupos ou em dupla;

- como as crianças agiam na ausência de suas professoras;

- interação das crianças com outras profissionais da escola em seu ambiente de trabalho - cozinheiras, funcionárias da limpeza, auxiliares.

Nesta primeira etapa da pesquisa, enquanto observava os ambientes de uso coletivo, a escola vinha desenvolvendo um projeto pedagógico que mobilizava a participação das crianças no processo de produção de registros com fotografia, permitindo, inclusive, que elas próprias manuseassem equipamentos fotográficos e produzissem suas próprias fotos. Com isso, foi possível acompanhar diferentes etapas desse projeto: momentos em que as crianças fotografavam, seleção das fotografias nos computadores da secretaria, até o encerramento - com uma

\footnotetext{
39 O diagrama consta no Anexo $D$ deste documento.
} 
exposição das fotografias das crianças aberta à comunidade, que marcou o final do ano letivo. Junto à gestão da escola, passou-se a discutir possibilidades para a elaboração de projetos semelhantes a este na pesquisa, para a criação de outras ações pedagógicas que envolvessem a fotografia no ano seguinte (2019), quando a observação participativa seria direcionada às turmas de Pré-A.

\section{ETAPA II - Observação dos quatro grupos (2019)}

O planejamento conjunto e o entrosamento com a equipe de gestão em 2018, acabou por influenciar, em alguma medida, uma decisão importante: em 2019, as integrantes da gestão retornaram à sala de aula e assumiram os grupos com crianças de 4-5 anos/Pré-A, pois desejavam continuar acompanhando de perto o desenvolvimento da pesquisa. Cabe, portanto, explicar a função exercida por estas educadoras, que se tornaram, junto às crianças, protagonistas na pesquisa. O diagrama a seguir (Figura 15) demonstra as posições ocupadas por cada uma delas durante os dois anos letivos de realização da pesquisa, em 2018 e 2019.

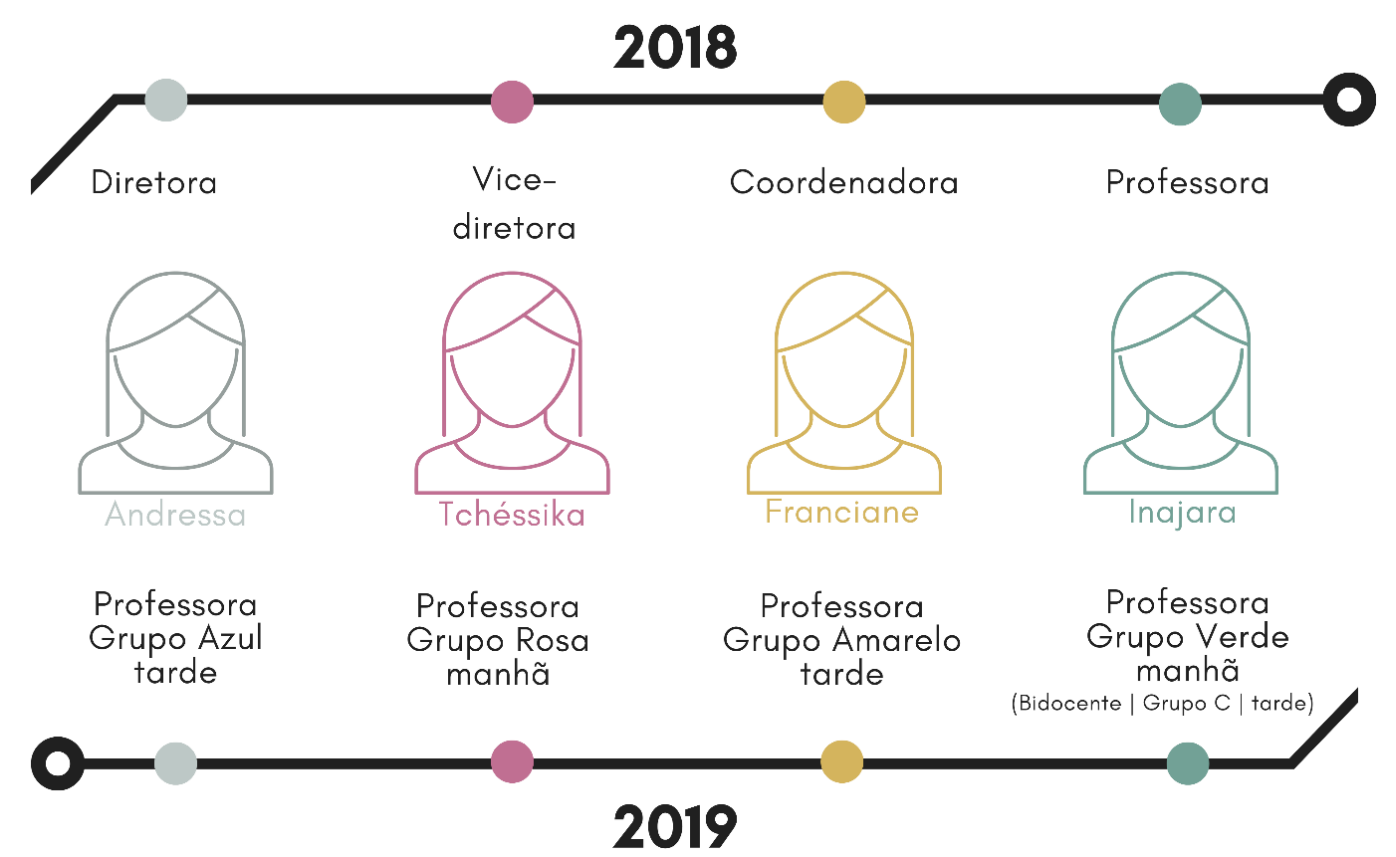

Figura 15 - Estrutura e organização da equipe Fonte: Elaborado pela autora.

Conforme demonstra a Figura 16, em 2018, quando a pesquisa iniciou, a equipe gestora formada pelas educadoras Andressa (diretora), Tchéssika (vicediretora) e Franciane (coordenadora pedagógica), cumpria o último ano de sua gestão - que havia iniciado em 2016. Em 2019, quando outra equipe assume a 
gestão da escola ${ }^{40}$, as três profissionais retomaram a função de professoras na própria escola, assumindo os grupos com as crianças de 4-5 anos ${ }^{41}$ daquele ano e, por isso, permaneceram envolvidas diretamente com a pesquisa. Juntou-se a elas outra professora, a Inajara, completando o grupo que participou da pesquisa até o final.

Na pesquisa, os grupos foram identificados por cores: Verde, Rosa, Azul e Amarelo. A Figura 16 apresenta esta caracterização de cada grupo quanto à identificação por cor, turno de atendimento, professora responsável, número de crianças matriculadas (meninas e meninos).

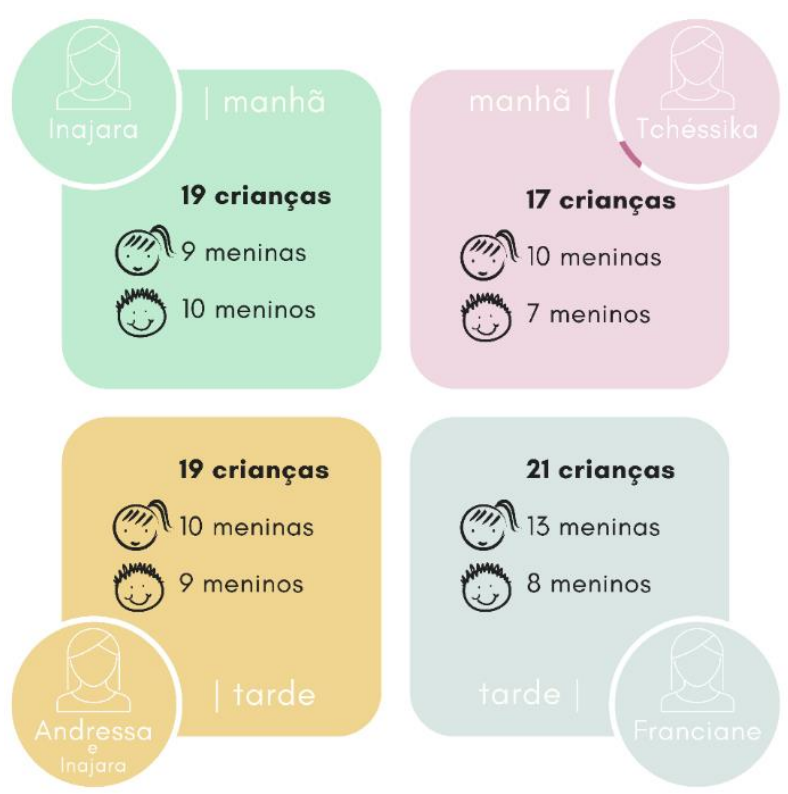

Figura 16 - Caracterização dos grupos

Fonte: Elaborado pela autora.

O tempo de observação foi equilibrado entre os quatro grupos, acompanhando cada um ao menos uma vez por semana, durante cinco meses abril, maio, junho, julho e agosto. $\mathrm{O}$ ano letivo havia iniciado em março, mas com a troca de gestão e no processo de adaptação de novas crianças à escola, a equipe decidiu que seria melhor iniciar a observação participativa a partir de abril.

Os primeiros dias de observação dos grupos tiveram como objetivo conhecer as crianças e tornar minha presença familiar aos grupos. Neste primeiro

\footnotetext{
40 A equipe que assumiu a gestão da escola em 2019 participou de forma indireta da pesquisa, motivo pelo qual optou-se por manter o anonimato destas profissionais.

${ }^{41} \mathrm{Na}$ rede municipal de ensino de Erechim, os níveis da educação infantil recebem nomenclaturas específicas, sendo "Pré A" o nível que corresponde aos grupos com crianças que tenham entre 4 e 5 anos de idade.
} 
contato, identificou-se características principais de cada grupo, os aspectos que mais chamavam atenção e que poderiam auxiliar no planejamento junto às professoras para condução das próximas propostas.

Concomitantemente às observações, acompanhei o planejamento pedagógico com as quatro educadoras para compreender como os momentos de fotografia eram pensados. Na escola, as professoras de cada nível costumavam se reunir quinzenalmente para planejarem juntas as propostas pedagógicas para seus grupos. Esse foi o primeiro aspecto questionado em conjunto para o andamento da pesquisa: por que os quatro grupos precisavam seguir o mesmo planejamento? Por que não partir de interesses próprios de cada grupo? Assim, decidiu-se que, em respeito à dinâmica da escola, as quatro professoras continuariam seguindo a proposta de projetos temáticos, mas procurariam traçar trajetórias diferentes, a partir de questões que fossem surgindo com a curiosidade e interesse das crianças em seu grupo.

Quatro projetos temáticos estiveram em vigência durante o período em que a pesquisa foi realizada, conforme demonstra o Quadro 5.

\begin{tabular}{c|c|c|c}
\multicolumn{2}{c}{ Título } & Duração & Abrangência \\
\hline "Erechim e seus encantos" & $\begin{array}{c}100 \text { anos da cidade } \\
\text { de Erechim-RS }\end{array}$ & $2017-2018$ & $\begin{array}{c}\text { Escolas da redes } \\
\text { municipal }\end{array}$ \\
"Lá vem história" & Literatura infantil & 2018 & EMEI Dom João \\
$\begin{array}{c}\text { "Cantar, dançar e brincar } \\
\text { para a magia realizar" }\end{array}$ & Música e sons & 2019 & EMEI Dom João \\
"A casa e seu dono" & Casas e moradias & jun/19 & $\begin{array}{c}\text { Grupos 4-5 anos I } \\
\text { EMEI Dom João }\end{array}$ \\
\hline
\end{tabular}

Quadro 5 - Projetos temáticos da escola Fonte: Elaborado pela autora.

Alguns desses projetos abrangem toda a rede municipal de ensino; outros são propostas exclusivas da escola; e também há projetos elaborados em conjunto pelas professoras de cada nível, como foi o caso do projeto "A casa e seu dono", desenvolvido pelos grupos de Pré A da escola, em junho de 2019.

Ao final do período de observação participativa, realizou-se avaliação com as crianças, por meio da estratégia de roda de conversa. As rodas de conversa foram realizadas em diferentes sessões, com pequenos grupos (em torno de 10 crianças por grupo), na sala de informática da escola. Com as cadeiras organizadas em semicírculo, as crianças conversaram livremente a partir de 
fotografias exibidas em uma apresentação. As fotografias exibidas correspondem aos registros feitos por mim durante todos os meses de inserção na escola. Tinhase $o$ intuito de saber, principalmente, quais as impressões das crianças a respeito das situações vivenciadas ao longo da pesquisa, a partir do que estava representado em fotografias feitas pela educadora. Nestas rodas de conversa, as crianças conversavam com liberdade determinados assuntos que não estavam necessariamente vinculados às vivências que vinham sendo conduzidas pelas educadoras com seus grupos. Apesar de já ter registrado por escrito algumas falas das crianças durante a observação participativa (estes registros fazem parte das notas de campo), surgiu também a necessidade de ouvir as crianças em um ambiente reservado.

\section{5 \\ Procedimentos de análise}

Os dados construídos com a imersão no campo de pesquisa foram de natureza diversa, considerando-se: notas de campo a partir das observações e participação em reuniões pedagógicas; gravações de áudio das entrevistas; e fotografias produzidas por mim. Esta variedade de dados, tornou complexa a definição dos procedimentos adotados na análise. Optou-se pela análise de conteúdo, desenvolvida por Bardin (1977, p. 42), definida como

[...] um conjunto de técnicas de análise das comunicações visando a obter, por procedimentos sistemáticos e objetivos de descrição do conteúdo das mensagens, indicadores (quantitativos ou não) que permitam a inferência de conhecimentos relativos às condições de produção/recepção (variáveis inferidas) destas mensagens.

Bardin (1977) estabelece três etapas fundamentais para o desenvolvimento da análise, que foram adaptadas e flexibilizadas a partir da revisão de Bauer (2008), conforme apresenta o diagrama a seguir (Figura 17): 

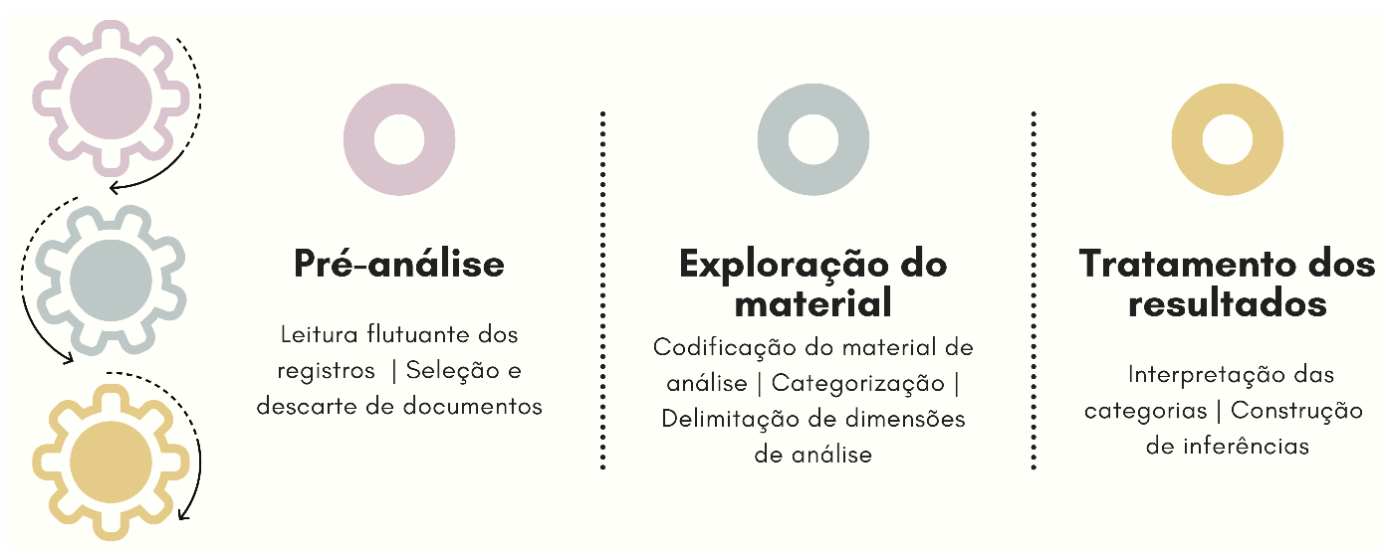

Figura 17 - Etapas da análise de conteúdo

Fonte: Bardin (1977); Bauer (2008), adaptado pela autora.

De acordo com o diagrama, os procedimentos realizados compreenderam: a) Pré-análise: leitura flutuante, organização e tabulação de todos os registros construídos durante a pesquisa de campo; seleção e descarte dos documentos para análise. b) Exploração do material: criação de códigos e comentários a partir de leitura atenta de todo o material; processo de construção de categorias e dimensões de análise; c) Tratamento dos resultados (inferências e interpretação): análise das categorias à luz do referencial teórico estudado e do cruzamento dos dados pela verificação de coocorrência de códigos.

$\mathrm{Na}$ análise de conteúdo, os dados foram tratados com apoio do software ATLAS.ti ${ }^{\circledR}{ }^{42}$, indicado para análises qualitativas com utilização de instrumentos e documentos variados. O software possibilitou a organização e acompanhamento dos documentos gerados na pesquisa de campo, contribuindo para a confiabilidade da análise.

Na pré-análise, realizou-se uma leitura flutuante de todos os documentos e registros coletados ao longo da pesquisa de campo, decidindo-se quais seriam incluídos ao projeto iniciado no ATLAS.ti. O Quadro 6 demonstra o corpus de pesquisa submetido a essa modelagem analítica, indicando a tipologia dos documentos e especificação de cada um deles quanto ao nome, data de produção, duração ou extensão do documento e o formato do arquivo.

\footnotetext{
${ }^{42}$ O ATLAS.ti é um software para a análise qualitativa de grandes corpos de dados textuais, gráficos, áudio e vídeo. Possui ferramentas sofisticadas que auxiliam a organização, remontagem e gestão do material de forma criativa, mas sistemática. É importante destacar que o software não analisa os dados pelo pesquisador, mas com os dados organizados é possível interpretá-los com mais segurança e confiabilidade.
} 


\section{Pré-análise: seleção de documentos}

\begin{tabular}{|c|c|}
\hline Tipo de documento & Especificação \\
\hline \multirow{4}{*}{ Entrevistas com educadoras } & $\begin{array}{l}\text { Entrevista Andressa - 10/12/2018 - Duração: 18'18" - Documento } \\
\text { de texto (transcrição) - } 6 \text { laudas }\end{array}$ \\
\hline & $\begin{array}{l}\text { Entrevista Franciane - 26/11/2018 - Duração: } 14^{\prime} 45^{\prime \prime} \text { - Documento } \\
\text { de texto (transcrição) - } 5 \text { laudas }\end{array}$ \\
\hline & $\begin{array}{l}\text { Entrevista Inajara - 10/12/2018 - Duração: 18'34" - Documento de } \\
\text { texto (transcrição) - } 6 \text { laudas }\end{array}$ \\
\hline & $\begin{array}{l}\text { Entrevis ta Inajara - } 26 / 11 / 2018 \text { - Duração: } 12^{\prime} 59^{\prime \prime} \text { - Documento de } \\
\text { texto (trans crição) - } 4 \text { laudas }\end{array}$ \\
\hline \multirow{3}{*}{$\begin{array}{l}\text { Registros escritos de reuniões } \\
\text { pedagógicas }\end{array}$} & $\begin{array}{l}\text { Reunião } 1 \text { - 17/12/2018 - Apresentação dos primeiros resultados } \\
\text { da pesquisa - } 1 \text { lauda }\end{array}$ \\
\hline & $\begin{array}{l}\text { Reunião } 2 \text { - 08/04/2019 - Planejamento das atividades de } \\
\text { pesquisa - } 1 \text { lauda }\end{array}$ \\
\hline & $\begin{array}{l}\text { Reunião } 3 \text { - 23/08/2019 - Planejamento das atividades de } \\
\text { pesquisa - } 1 \text { lauda }\end{array}$ \\
\hline Notas de campo & $\begin{array}{l}\text { Registros escritos da pesquisadora a partir de observação } \\
\text { participativa - 2018/2019 - } 12 \text { laudas }\end{array}$ \\
\hline \multirow{2}{*}{ Fotografias } & $\begin{array}{l}\text { Registros fotográficos da pesquisadora - } 2018 \text { - } 375 \text { imagens } \\
\text { (formato JPG) }\end{array}$ \\
\hline & $\begin{array}{l}\text { Registros fotográficos da pesquisadora - } 2019 \text { - } 511 \text { imagens } \\
\text { (formato JPG) }\end{array}$ \\
\hline
\end{tabular}

Quadro 6 - Pré-análise: seleção de documentos

Fonte: Elaborado pela autora.

Cabe considerar que alguns dos documentos produzidos ao longo da pesquisa foram descartados na pré-análise, entre eles, os registros em áudio das rodas de conversa realizadas com as crianças ao final da imersão na escola. Após a leitura flutuante dos áudios gravados nessas sessões de conversa, identificouse que o conteúdo não correspondia aos demais documentos que seriam analisados, pois a fala das crianças não havia sido conduzida a partir de um questionário semiestruturado, como o que foi aplicado às educadoras em entrevista. Além disso, nem todos os grupos falaram sobre o tema "fotografia", pois as falas das crianças foram espontâneas e tomaram rumos diferentes em cada sessão. Reconhecendo a relevância deste conteúdo e a importância da escuta das crianças, esses dados foram considerados na etapa posterior ${ }^{43}$.

Com os documentos selecionados e incluídos ao ATLAS.ti, iniciou-se a exploração do material e o processo de codificação, que se deu a partir da leitura

\footnotetext{
${ }^{43}$ As gravações de áudio das rodas de conversa foram transcritas e alguns desses diálogos com as crianças complementaram a elaboração das mini-histórias apresentadas na última sessão/ Parte IV - Documentar.
} 
atenta de todos os documentos. No software, é possível criar códigos, que são palavra ou frases capazes de resumir, salientar ou capturar a essência e/ou evocar os atributos de uma porção de dados (escritos ou visuais) (Saldaña, 2009, p. 0304). É importante destacar que codificar não é apenas "rotular" trechos dos documentos, mas relacionar ideias e dados à luz do aporte teórico estudado. É um processo analítico por meio do qual os dados são divididos, conceitualizados e integrados teoricamente (Corbin; Strauss, 1998).

Os códigos criados nesta etapa de exploração do material dizem respeito às nuances da documentação com apoio da fotografia, tendo suscitado a partir da leitura dos dados e da recorrência de termos que emergem dos documentos. Em um primeiro processo de codificação, foram criados 164 códigos e 37 "memos" (notas sobre a interpretação da pesquisadora).

O ATLAS.ti também facilita a atribuição de famílias de códigos às unidades de análise com significado para a pesquisa, tendo como referência a interpretação do conteúdo (Bardin, 1977; Bauer, 2008). Este processo de associação de códigos a unidades de registro resultou em 16 codificações principais. Dez códigos emergiram a partir de conceitos e proposições teóricas que ancoram a pesquisa, portanto, foram chamados de códigos teóricos. Estes foram definidos a priori, pois referiam-se a aspectos que já se pretendia investigar antes da imersão na escola. Os outros seis surgiram a partir da observação participativa e/ou de falas das educadoras em entrevista e, por este motivo, foram chamados de códigos empíricos. Este grupo reúne códigos que se apresentaram como novidade, de forma inesperada ou não prevista anteriormente. Para que se possa compreender a aplicabilidade de cada código na sequência da análise, apresenta-se, a seguir, um glossário (Quadro 7) com os 16 códigos acompanhados dos sentidos atribuídos a partir da minha óptica. 


\section{Glossário de códigos}

\begin{tabular}{|c|c|c|}
\hline & Código & Sentido e Aplicabilidade \\
\hline \multirow{10}{*}{ 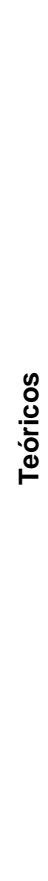 } & 1. Avaliação & Utilização da fotografia para fins de avaliação das crianças. \\
\hline & 2. Currículo & $\begin{array}{l}\text { O ato de fotografar na organização curricular e concepções de } \\
\text { currículo da escola. }\end{array}$ \\
\hline & 3. Intencionalidade & Propósitos e intenções das educadoras ao fotografarem. \\
\hline & 4. Local e Global & Implicações da utilização da fotografia a nível micro e macro. \\
\hline & 5. Observação & $\begin{array}{l}\text { Sistematização das práticas de observação das crianças e } \\
\text { produção de registros fotográficos das aprendizagens e vivências. }\end{array}$ \\
\hline & 6. Participação & $\begin{array}{l}\text { Atuação das crianças no processo de registrar e documentar } \\
\text { com fotografia. }\end{array}$ \\
\hline & 7. Planejamento & $\begin{array}{l}\text { Organização para produção de fotografias e construção da } \\
\text { documentação pedagógica. }\end{array}$ \\
\hline & 8. Qualidade & $\begin{array}{l}\text { A fotografia para aprimoramento da qualidade da educação } \\
\text { oferecida às crianças. }\end{array}$ \\
\hline & 9. Teoria e Prática & $\begin{array}{l}\text { Concepções teóricas e práticas de fotografia e documentação } \\
\text { pedagógica. }\end{array}$ \\
\hline & 10. Trabalho em equipe & $\begin{array}{l}\text { Ações colaborativas entre as educadoras da escola para } \\
\text { fotografar e documentar. }\end{array}$ \\
\hline \multirow{6}{*}{ 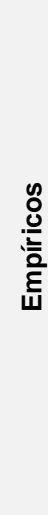 } & 11. Ambientes invisibilizados & Espaços da escola que raramente são fotografados. \\
\hline & 12. Cuidado & $\begin{array}{l}\text { Fotografia como comprovação do bem-estar da criança como } \\
\text { responsabilidade da escola e das educadoras. }\end{array}$ \\
\hline & 13. Exposição da criança & $\begin{array}{l}\text { Situações em que a fotografia expõe a imagem das crianças de } \\
\text { forma invasiva e/ou desnecessária (preceitos éticos). }\end{array}$ \\
\hline & 14. Exposição do adulto & $\begin{array}{l}\text { Situações em que a fotografia expõe de forma negativa as } \\
\text { educadoras ou aspectos de seu trabalho (preceitos éticos). }\end{array}$ \\
\hline & 15. Momentos privigiados & Atividades pedagógicas fotografadas com frequência. \\
\hline & 16. Processos de aprendizagem & $\begin{array}{l}\text { Registros fotográficos de sequências pedagógicas ou diferentes } \\
\text { etapas de uma atividade }\end{array}$ \\
\hline
\end{tabular}

Quadro 7 - Glossário de códigos

Fonte: Elaborado pela autora.

Com os códigos criados, iniciou-se o processo de categorização - que consistiu no agrupamento imposto aos segmentos de códigos a partir da comparação entre os códigos iniciais. Buscou-se por padrões que poderiam aparecer através de: similaridade, diferença, frequência (ou ausência), sequência (indicando uma ordem), correspondência ou causa. Neste processo, relacionamse código e categorias de forma cíclica, avançando sobretudo com a familiaridade dos dados (Corbin; Strauss, 1998).

A construção das categorias na pesquisa partiu de quatro perguntas simples: O que é fotografado? E o que não é fotografado? Onde estão as fotos? Em que lugares não há fotos? A resposta para estas perguntas conduziu a análise 
ao grupo de códigos empíricos, constituindo-se duas categorias mais amplas: Luzes e Sombras - que contemplam, respetivamente, o que é visto e o que não é visto; o que é fotografado e o que não é fotografado no contexto educativo. A Figura 18 demonstra a correspondência entre as categorias mais amplas e seis códigos que emergiram do campo empírico ${ }^{44}$.

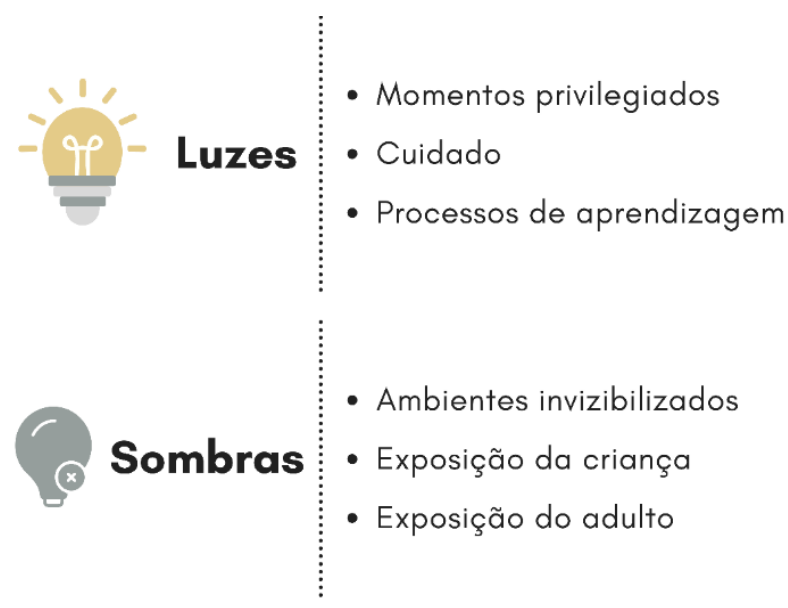

Figura 18 - Categorias e dimensões de análise Fonte: Elaborado pela autora.

Os quadros a seguir apresentam o modelo analítico aplicado às dimensões de análise no âmbito das categorias Luzes e Sombras. Nesse sentido, o Quadro 8 destaca como foram analisados os dados a respeito do que é fotografado e das fotografias que são expostas na escola.

\footnotetext{
${ }^{44} \mathrm{~A}$ árvore de códigos e dimensões de análise, elaborada no ATLAS.ti, consta no Apêndice D.
} 


\begin{tabular}{|c|c|c|}
\hline \multicolumn{3}{|c|}{ Dados da categoria: "Luzes" } \\
\hline Dimensão de análise & & Caracterização dos dados \\
\hline \multirow{2}{*}{$\begin{array}{l}\text { Momentos } \\
\text { privilegiados }\end{array}$} & Observou-se que: & $\begin{array}{l}\text { - Atividades coletivas e de integração são fotografadas } \\
\text { com frequência }\end{array}$ \\
\hline & Educadoras dizem que: & $\begin{array}{l}\text { - São atividades "diferentes", "destaque", "interessantes", } \\
\text { "grandes", "principais", "especiais", "importantes", "muito } \\
\text { específicas" ou "mais legais" }\end{array}$ \\
\hline \multirow{2}{*}{ Cuidado } & Observou-se que: & $\begin{array}{l}\text { - As educadoras procuram fotografar momentos em que } \\
\text { as crianças estão socializando com os pares }\end{array}$ \\
\hline & Educadoras dizem que: & $\begin{array}{l}\text { - É preciso mostrar à família a felicidade e o bem-estar } \\
\text { da criança na escola }\end{array}$ \\
\hline \multirow{3}{*}{$\begin{array}{l}\text { Processos de } \\
\text { aprendizagem }\end{array}$} & Observou-se que: & $\begin{array}{l}\text { - As educadoras fotografam diferentes etapas e ângulos } \\
\text { de uma mesma atividade }\end{array}$ \\
\hline & & - Fotografam de diferentes ângulos \\
\hline & Educadoras dizem que: & $\begin{array}{l}\text { - Constroem sequências de fotografias para dar sentido } \\
\text { ao momento de aprendizagem }\end{array}$ \\
\hline
\end{tabular}

Quadro 8 - Dados da categoria: "Luzes"

Fonte: Elaborado pela autora.

As dimensões de análise foram verificadas em observação ("Observou-se que...") e diálogos transversais (“Educadoras dizem que..."). A análise mostra que as "luzes" estão em três dimensões, construídas a partir de outras questões:

- Momentos privilegiados: Que momentos ou vivências estão sendo fotografados e de que forma são escolhidos? Qual o espaço desses momentos no currículo da escola?

- Cuidado: Por que as educadoras fotografam apenas momentos em que a criança expressa felicidade? A quem se deseja mostrar isso?

- Processos de aprendizagem: Em que medida a fotografia é capaz de retratar com veracidade os processos de aprendizagem? Como é possível representar ideia de continuidade e sequência aos fatos pela fotografia? 
O Quadro 9 apresenta as dimensões de análise e caracterização dos dados da categoria "Sombras".

\section{Dados da categoria: "Sombras"}

\begin{tabular}{|c|c|c|}
\hline Dimensão de análise & & Caracterização dos dados \\
\hline \multirow{3}{*}{$\begin{array}{c}\text { Ambientes } \\
\text { invisibilizados }\end{array}$} & \multirow{2}{*}{ Observou-se que: } & $\begin{array}{l}\text { - Rececepção, refeitório, banheiros e salas } \\
\text { administrativas não foram fotografados }\end{array}$ \\
\hline & & $\begin{array}{l}\text { - Os espaços geralmente são organizados antes de } \\
\text { serem fotografados }\end{array}$ \\
\hline & Educadoras dizem que: & - É preciso "esconder a bagunça" da fotografia \\
\hline \multirow{2}{*}{$\begin{array}{l}\text { Exposição da } \\
\text { criança }\end{array}$} & Observou-se que: & $\begin{array}{l}\text { - Situações de choro e desentendimento entre as } \\
\text { crianças não são fotografadas }\end{array}$ \\
\hline & Educadoras dizem que: & - É preciso evitar o constrangimento da criança \\
\hline \multirow{4}{*}{$\begin{array}{l}\text { Exposição do } \\
\text { adulto }\end{array}$} & Observou-se que: & $\begin{array}{l}\text { - As educadoras assumem a tarefa de fotografar e nem } \\
\text { sempre aparecem na fotografia }\end{array}$ \\
\hline & \multirow{3}{*}{ Educadoras dizem que: } & - Gostariam de aparecer na fotografia \\
\hline & & - Não tem quem fotografe por elas \\
\hline & & - Preferem ser avisadas antes de serem fotografadas \\
\hline
\end{tabular}

Quadro 9 - Dados da categoria: "Sombras" Fonte: Elaborado pela autora.

Durante os momentos de observação, o desafio maior esteve em identificar as "sombras", pois nem sempre o que é invisível está dado, não são informações que aparecem com clareza nas narrativas construídas pelas educadoras. É neste momento que o olhar do pesquisador se torna determinante, mapeando não só o que está evidente, mas também lacunas que estejam subjacentes ao cenário corriqueiro do cotidiano.

Identificou-se que o que se evitava mostrar com a fotografia esbarrava, principalmente, em preocupações éticas e estéticas das educadoras, que deram origem a outras dimensões de análise, também organizadas em torno de novos questionamentos:

- Ambientes invisibilizados: Que espaços da escola não são contemplados com as fotografias das educadoras? Como os espaços são organizados para serem fotografados? Em que espaços não há fotografias expostas? Por que isso acontece?

- Exposição da criança: Que cuidados são tomados em relação à forma com que a criança é exposta nas fotografias? Existem consensos entre as educadoras em relação a isso? Que imagem das crianças se pretende? 
comunicar

- Exposição do adulto: Qual o espaço do adulto nas imagens produzidas? As educadoras aparecem nas fotografias? De que forma expõem seu trabalho nas imagens?

\section{Coocorrência de códigos}

\begin{tabular}{|c|c|c|c|c|c|c|c|}
\hline & \multicolumn{6}{|c|}{ Dimensões de análise } \\
\hline & & \multirow[b]{2}{*}{ 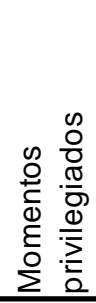 } & \multicolumn{2}{|c|}{ LUZES } & \multicolumn{3}{|c|}{ SOMBRAS } \\
\hline & & & $\begin{array}{l}\text { 음 } \\
\frac{\pi}{0} \\
\frac{0}{3} \\
0\end{array}$ & 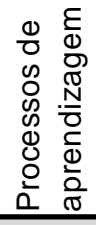 & 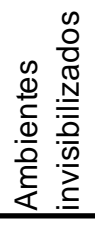 & 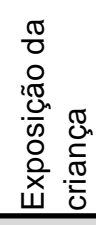 & 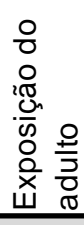 \\
\hline \multirow{10}{*}{ 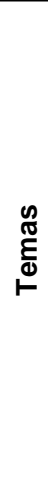 } & Avaliação & 0 & 0 & 1 & 0 & 1 & 1 \\
\hline & Currículo & 0 & 0 & 1 & 2 & 0 & 0 \\
\hline & Intencionalidade & 0 & 0 & 1 & 0 & 1 & 1 \\
\hline & Local e Global & 2 & 0 & 0 & 0 & 0 & 0 \\
\hline & Observação & 0 & 1 & 2 & 1 & 0 & 0 \\
\hline & Participação & 1 & 0 & 0 & 0 & 0 & 0 \\
\hline & Planejamento & 0 & 0 & 1 & 0 & 0 & 0 \\
\hline & Qualidade & 0 & 1 & 0 & 0 & 0 & 1 \\
\hline & Teoria e Prática & 0 & 0 & 0 & 0 & 0 & 0 \\
\hline & Trabalho em equipe & 0 & 0 & 2 & 0 & 0 & 1 \\
\hline
\end{tabular}

Quadro 10 - Coocorrência de códigos Fonte: Elaborado pela autora.

Com os códigos empíricos organizados e categorizados, a próxima tarefa foi verificar sua relação com os códigos teóricos que, na pesquisa, foram chamados de "temas". Para isso, utilizou-se a ferramenta de análise "coocorrência de códigos" do ATLAS.ti, que gerou um quadro com o cruzamento de temas (eixo vertical) com as dimensões de análise (eixo horizontal) (Quadro 10).

Para explicar como a coocorrência de códigos produziu sentido na análise, cita-se o exemplo do tema "Avaliação", que aparece em coocorrência com três dimensões de análise: "Processos de aprendizagem" (1 coocorrência), "Exposição da criança" (1 coocorrência) e "Exposição do adulto" (1 coocorrência). Exemplificando: a análise da correlação entre o tema "Avaliação" e a dimensão de análise "Processos de aprendizagem", pode ser explicada pelo fato de que os registros fotográficos de sequências pedagógicas ou diferentes etapas de uma vivência (Código: Processos de aprendizagem) podem ser utilizados com fins de avaliação das crianças (Código: Avaliação). 
Analisando o Quadro 10, percebemos que nove dos dez temas, oriundos do campo teórico, se correlacionam com pelo menos uma das seis dimensões de análise de cada categoria. Contudo, destacou-se que o tema "Teoria e Prática" que diz respeito às concepções das educadoras sobre documentação pedagógica e fotografia -, não possui coocorrência com nenhuma das dimensões de análise do campo empírico. Isto se justifica pelo fato de que esta temática não ficou evidente à minha leitura durante a observação participativa. Ou seja, não foi possível identificar uma relação entre as concepções teóricas das educadoras e suas propostas pedagógicas, aspecto relevante ao âmbito da pesquisa-ação.

Para que este dado fosse incluído à análise, restabeleceu-se um diálogo com as educadoras participantes, no primeiro semestre de 2020 , durante 0 período de isolamento social em decorrência da pandemia de Covid-19. Realizouse uma conversa virtual através de chamada de vídeo, com a participação de três educadoras que acompanharam todo o percurso de imersão na escola (Andressa, Franciane e Tchéssika), que hoje atuam em outras escolas ou instâncias administrativas da rede municipal de ensino de Erechim. O intuito deste "encontro" foi revisitar questões feitas nas primeiras entrevistas, para que fossem identificados possíveis aprimoramentos no pensamento crítico e teórico das educadoras após a experiência de terem participado da pesquisa. A conversa foi gravada em arquivos de áudio e, posteriormente, transcrita. Esta conversa contribuiu com a avaliação da pesquisa-ação, apresentada nas considerações finais da tese.

\section{6 Proposições para análise das fotografias}

A adoção de uma metodologia menos rígida de observação participativa, com uma "sensibilidade ao design" do contexto (Project Zero, 2020), gerou certa insegurança durante o percurso da pesquisa-ação. As evidências que foram surgindo nem sempre pareciam ser dados relevantes à pesquisa, havendo receio de que o campo suscitasse aspectos que não necessariamente se conectariam com as perguntas norteadoras. Por outro lado, a oportunidade de olhar de forma mais sensível para o contexto educativo, sem que houvesse um cronograma fixo de atividades, proporcionou mais liberdade ao processo de documentação na pesquisa, sobretudo em relação à fotografia. Muitas situações que emergiram do contexto foram sendo fotografadas sem que se soubesse com precisão se esses 
registros contribuiriam com a análise. O resultado foi a composição de um acervo imagético rico de sentidos, que narra pelos meus olhos as trajetórias de adultos e crianças na pesquisa. Produzir fotografias e analisá-las de forma independente não era um objetivo inicial da pesquisa, mas se tornou uma possibilidade que emergiu da potência da dimensão estética no processo de documentar e narrar a pesquisa-ação.

Spaggiari $\left(2020\right.$, p. $\left.x v^{45}\right)$ problematiza uma cultura pedagógica que tende a supervalorizar textos escritos, denunciando que os livros de pedagogia estão "saturados de palavras" e raramente trazem imagens. Para o autor, essa ausência de desenhos e fotografias na escrita pedagógica, tem marcado uma cultura que privilegia o excesso de textos em detrimento dos contextos; ou o excesso de textos desconectados de contextos. Esta crítica também pode ser transposta ao âmbito acadêmico, onde o padrão da escrita é tradicionalmente imposto como modelo para apresentação de resultados das pesquisas científicas, em detrimento de produções que se utilizam da linguagem visual.

Tendo na tese uma proposta de valorização da fotografia como uma linguagem completa e plena de sentidos, caberia uma exploração complementar da riqueza do material empírico construído com as fotos. Assim, optou-se pela ampliação na análise e aplicação de um tratamento analítico específico às fotografias produzidas no campo, a fim de complementar os resultados alcançados na análise de conteúdo, atribuindo outros significados às imagens que seriam incluídas à tese.

O caminho adotado para esta análise complementar faz parte de uma iniciativa de investigadores do Grupo de Pesquisa em Educação e Mídias GRUPEM, da PUC-Rio, coordenado pela professora Dra. Rosália Duarte. O grupo vem testando metodologias mais usadas nos campos de estudos da filosofia da imagem, da estética e das artes. Em sua tese de doutorado, Beatriz M. de A. Porto Gonçalves (2019) elaborou um atlas do audiovisual escolar, seguindo um percurso analítico aberto a partir da apropriação dos escritos do francês, filósofo e historiador da arte, Georges Didi-Huberman. Tal método se baseia livremente no formato de $\mathrm{Atlas}^{46}$, como um instrumento ao mesmo tempo estético e científico e que, portanto, combina e tenciona saberes da ordem do sensível e da ordem da razão científica (Didi-Huberman, 2013, p. 11).

\footnotetext{
45 Spaggiari (2020), paginação em formato E-pub/Kindle.

46 Didi-Huberman, por sua vez, se baseou no atlas criado por Aby Warburg.
} 
Seguindo a proposta de Gonçalves (2019), também me desafio à elaboração de um Atlas, como uma forma visual de organizar e dar sentido às fotos que foram produzidas durante a pesquisa. $O$ atlas, tal como conhecemos, é um gênero de livro geográfico, composto pela compilação de diversos mapas. Avançando nesta ideia, a construção de um atlas nesta tese é uma experiência estética/criativa, de "construção de saberes, conhecimentos, sentidos, sentimentos e significados" (Gonçalves, 2019, p. 23), que se deu pelo mapeamento das vivências que tive na imersão feita na escola, narradas pelas fotografias.

$\mathrm{Na}$ perspectiva do atlas como método investigativo, as memórias construídas na pesquisa não são cumulativas e se constroem na ordem do sensível e do subjetivo. O atlas foi apresentado visualmente com a elaboração de um mosaico de significações (Figura 19). Entendo por mosaico, a construção de um design pela técnica de montagem das fotos como pequenas peças. Nesta significação, cabe explicar que as fotos foram categorizadas a partir dos códigos propostos na análise de conteúdo, mas esta organização no mosaico é produto da minha construção estética/sensível do percurso vivido na escola e que, portanto, não é tangível aos olhos de todos. $\mathrm{Na}$ análise de conteúdo, todas as fotografias que produzi foram quantificadas, codificadas, categorizadas e interpretadas e, assim, as imagens foram ganhando sentido. As fotos/peças não produzem sentido quando vistas isoladamente, mas dentro do mosaico apresentam uma ideia do todo, contextualizas e inter-relacionadas. 


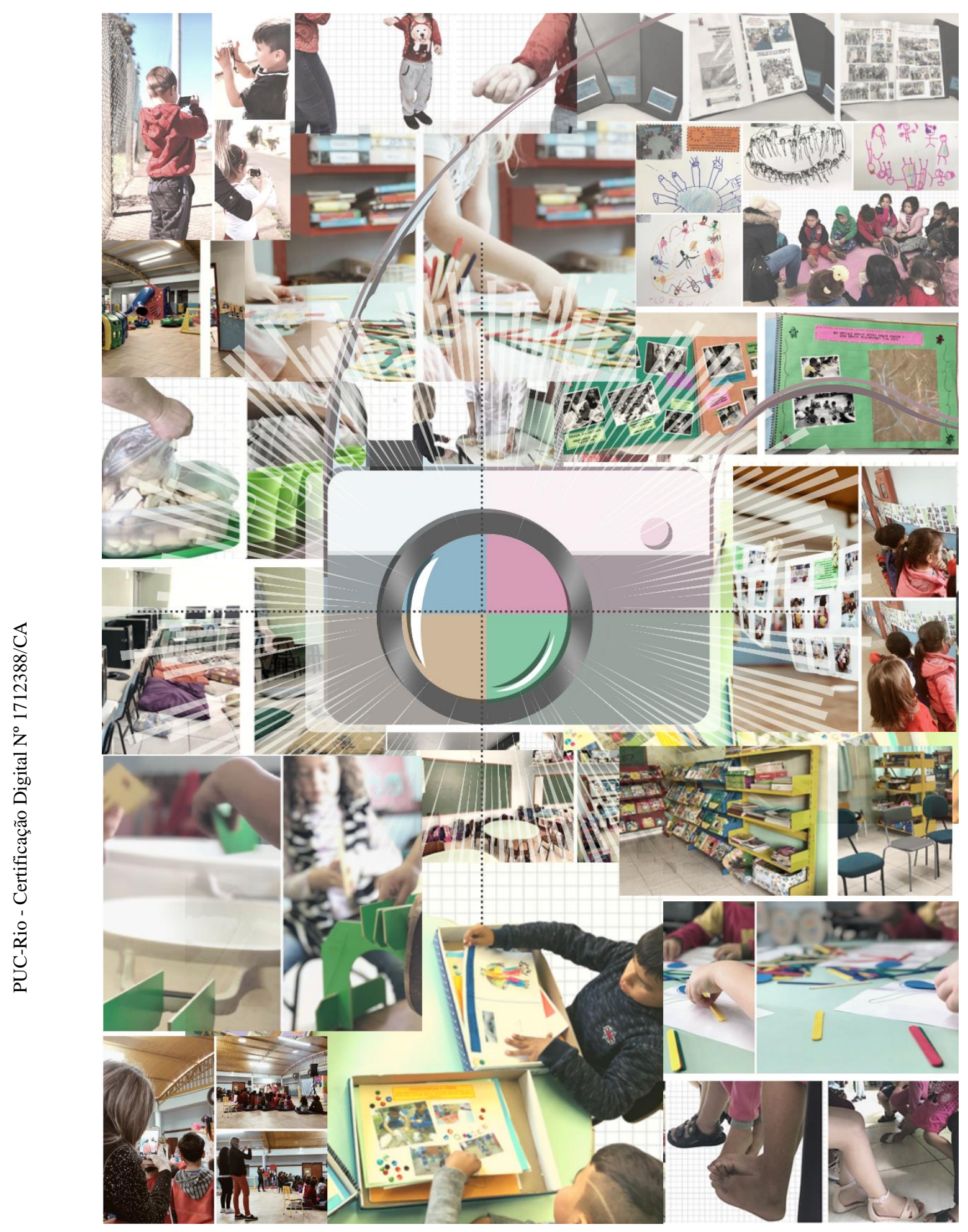

Figura 19 - Mosaico de significações Fonte: Acervo da autora.

Após a análise de conteúdo e a elaboração do mosaico, embora as questões de pesquisa tivessem sido contempladas, percebeu-se que uma parte robusta dos registros fotográficos produzidos havia "sobrado", deixando a sensação de que se tinha dado pouca atenção a este material. Surgem, assim, algumas questões: 
Qual o sentido das imagens que não se englobam em nenhuma das categorias analisadas? Estas imagens possuem menos valor que as demais? O que estas imagens contam? Esta narrativa não é válida à tese?

Encorajei-me na proposição de Didi-Huberman (2015), em que se assume o risco de interpretar o inverificável, de não se contentar com os não-saberes. Assim, as imagens não pertencentes às categorias da análise de conteúdo, foram tomadas como rasgo/fissura, construindo sentido pelo que não mostram, pelo "tudo" que não vemos. Provocam sentido pelo sintoma, termo que designa uma dialética segundo a qual a imagem provoca de uma só vez ao olhar quando é apresentada, liberando de forma complexa uma memória latente e eficaz. As memórias suscitadas por estas imagens, deram origem a mini-histórias, pequenas narrativas com apoio das imagens, que contam os percursos de investigação das crianças na experimentação da linguagem fotográfica, ao longo do percurso no campo. Esta etapa complementar à análise foi apresentada detalhadamente na Parte IV-Documentar (p. 158). 


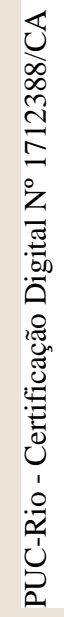

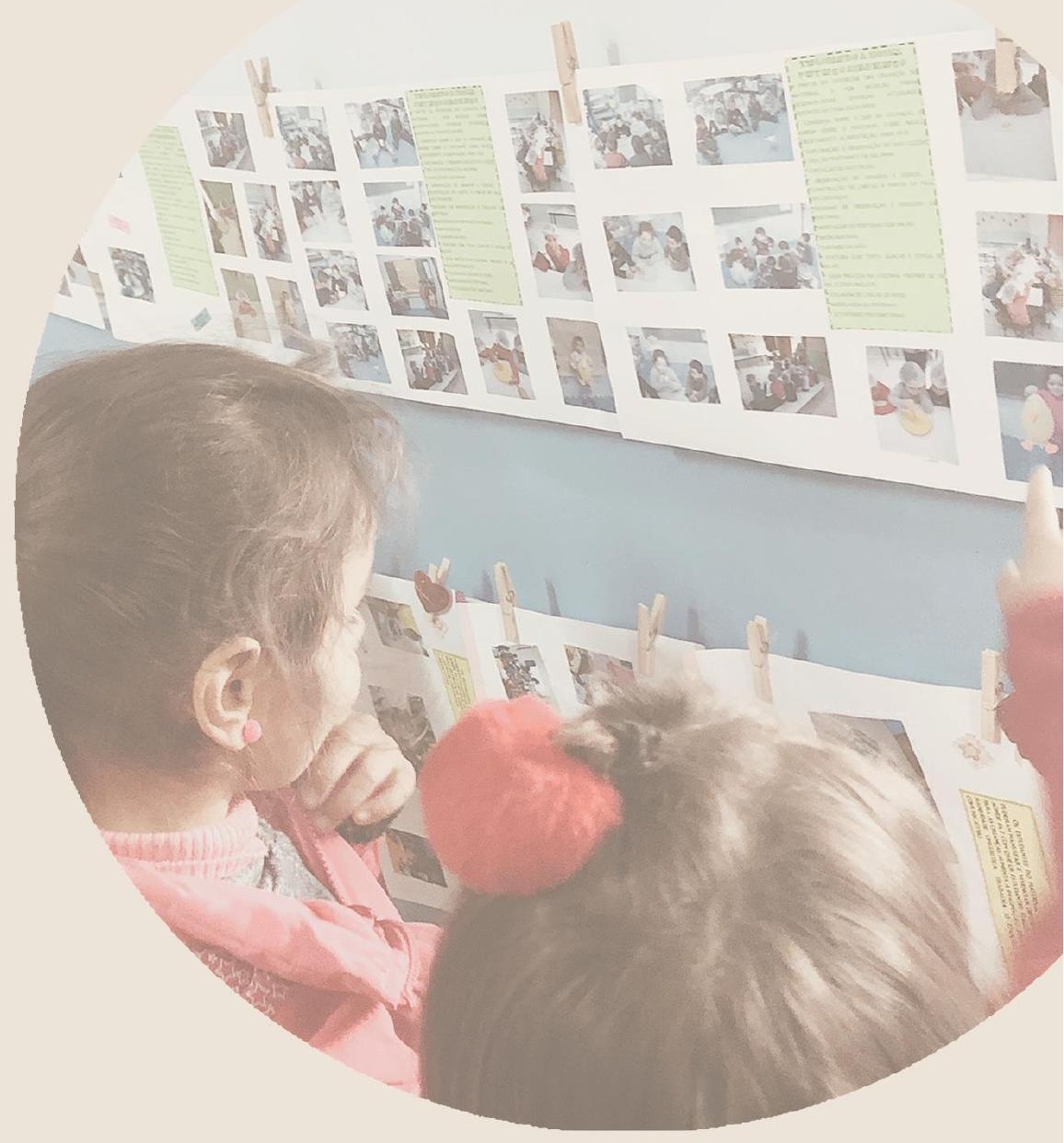

Discutir 


\section{4 \\ Luzes e sombras: a que processos se escolhe dar visibilidade?}

Durante a pesquisa-ação, os sentidos foram aguçados para as minúcias, detalhes e sutilezas que não devem escapar aos olhos do pesquisador. Buscouse identificar os usos dados à fotografia na escola, o que vinha sendo registrado com este dispositivo, quem assumia a tarefa de fotografar, em que momentos o fazia e com que intenções. Isto também foi avaliado no decorrer das entrevistas e nas reuniões formativas realizadas com as educadoras, com perguntas que ajudaram a construir uma análise das observações do cotidiano vivenciado pelas crianças no desenvolvimento dos projetos temáticos.

Interpretar o que se torna visível pela documentação significa reconhecer que todas as ações de observação e registro no contexto da educação infantil são produto de escolhas subjetivas dos atores sociais envolvidos no processo educativo. Escolhas estas, que estão intimamente relacionadas à perspectiva curricular da escola e dos sujeitos. Neste viés, o currículo é entendido como um artefato cultural, forjado em um terreno de disputas e embates políticos. As discussões que questionam a construção curricular não se desenvolvem sob uma perspectiva consensual, mas em esferas de negociação, ambivalência, parcialidade e dinamismo (Silva, 2005; Lopes; Macedo, 2003; Hall, 2003).

A análise de conteúdo tornou possível compreender a que processos a fotografia dá visibilidade, mas também o que pode ser "invisibilizado". Nesta perspectiva, foram analisadas duas categorias mais amplas: Luzes e Sombras.

Os dados construídos a partir da observação participativa e dos diálogos transversais com as educadoras, indicam que existiam padrões e consensos em relação aos ambientes e momentos que deveriam ser registrados com foto e, também, na forma de comunicar as fotografias produzidas a outros grupos sociais. Esses padrões identificados dizem respeito a dois segmentos centrais na rotina das escolas infantis, o espaço e o tempo - que na análise foram avaliados pelos usos dados a fotografia nos ambientes da escola e nos momentos pedagógicos pensados pelos adultos, respectivamente.

Espaço e tempo são dimensões que se constituem nas apropriações dos sujeitos e suas territorialidades. Tomando como base o campo de reflexão da 
Geografia da Infância ${ }^{47}$, a infância é concebida em um espaço de negociação, nas culturas produzidas pelas próprias crianças, a partir dos lugares que os adultos destinam a elas em suas instituições (Lopes, 2008; Lopes; Vasconcellos, 2005; Lopes, 2003).

Dessa forma, os sentidos produzidos pela análise das "luzes" e das "sombras" são atravessados pelas dimensões de espaço e tempo que, ao se agregarem com as vivências das crianças e dos adultos, produzem diferentes arranjos culturais e simbólicos. Para Lopes (2008, p. 67), as crianças, ao se apropriarem das dimensões de tempo e espaço, "as reconfiguram, as reconstroem, e ao se criarem, criam suas diferentes histórias e geografias".

Nos espaços da escola em que havia fotografias expostas, como é o caso dos corredores que davam acesso às salas de cada grupo, percebeu-se que as fotos eram capazes de atrair a atenção tanto das crianças quanto dos visitantes que chegavam à escola.

$\mathrm{Na}$ situação representada na Figura 20, as crianças do Grupo Rosa visualizavam as fotos de outro grupo, expostas em um varal, enquanto aguardavam para entrar no refeitório para o lanche. Comentavam entre si sobre os colegas conhecidos de outros grupos, dizendo seus nomes e indicando a sala em que estudavam. As fotografias expostas nesses espaços se sobrepunham a outros registros (desenhos e outras produções das crianças). Ao identificar rostos conhecidos nas fotos, as crianças pareciam se reconhecer nesse espaço e se sentir inseridas socialmente no contexto da escola.

\footnotetext{
${ }^{47} \mathrm{O}$ campo de estudos da Geografia da Infância tem se proposto a compreender a infância através do espaço geográfico e de suas expressões. O campo tem se constituído como possibilidade de apresentar as contribuições da Geografia para os estudos da infância, como tem feito outras áreas do conhecimento, como a Sociologia da Infância e a Antropologia da Infância. No Brasil, ainda é um campo com pouca inserção acadêmica, que vem sendo assumido a partir do diálogo com referenciais da perspectiva histórico-cultural de Vigotski e demais colaboradores (Lopes, 2008; Lopes; Vasconcellos, 2005; Lopes, 2003).
} 

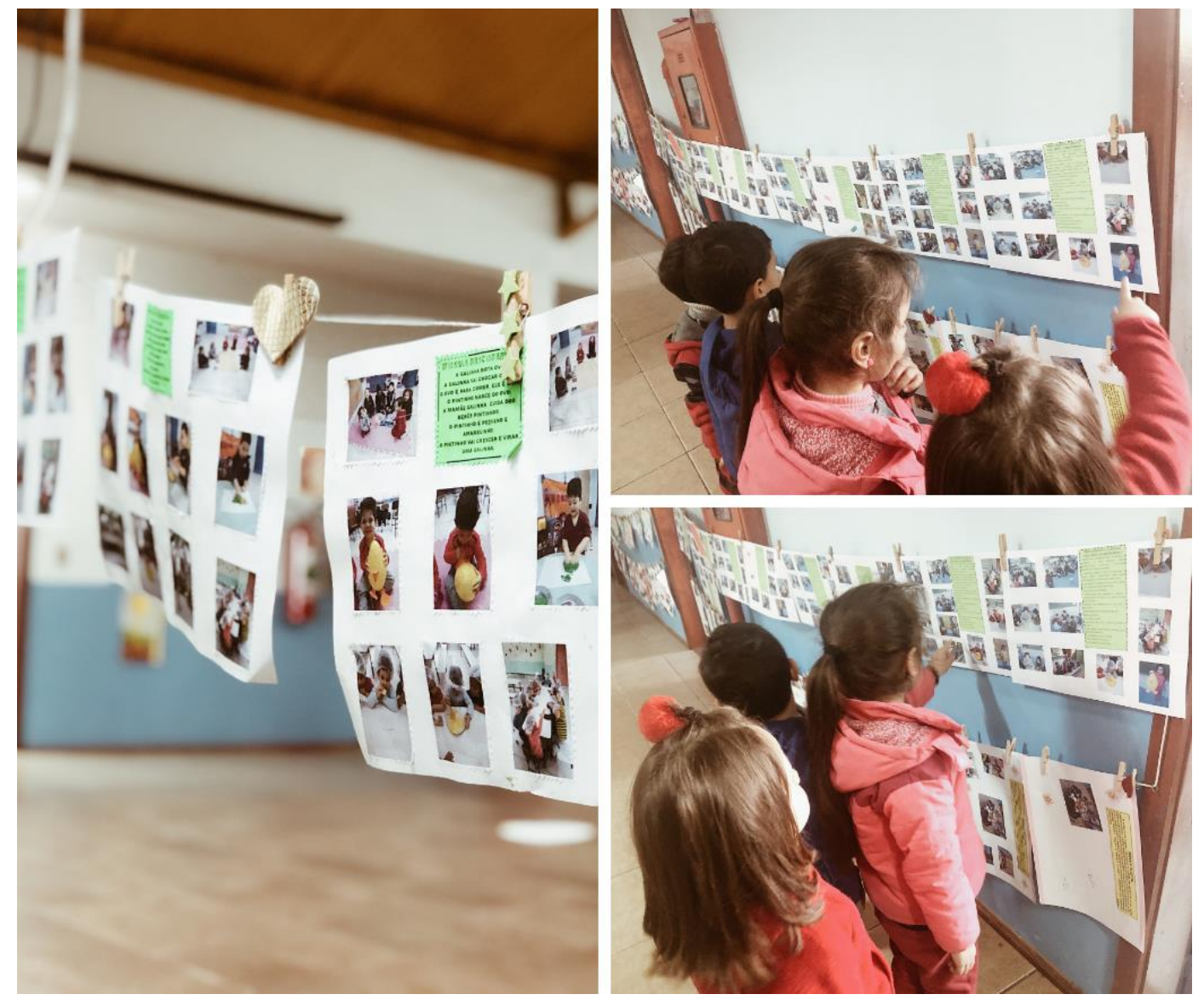

Figura 20 - Exposição de fotos no corredor Fonte: Acervo da autora.

Os momentos fotografados, em especial aqueles que marcam as temáticas abordadas nos projetos, são os que possuem centralidade na documentação e no currículo da escola. Professoras e gestoras se revezam para que os projetos sejam documentados com fotografia, sistematicamente. As fotografias costumam ser impressas e depois são anexadas aos portfólios individuais das crianças ou ao álbum de fotos da escola de cada ano. A escola ainda comunica sua documentação através de mídias sociais, práticas estas analisadas em estudos sobre portfólios digitais (Arndt; Tesar, 2015; Beaumont-Bates, 2017; Picher, 2019).

Contudo, embora a escola produzisse um trabalho pedagógico em que a fotografia possui protagonismo no processo de documentar as aprendizagens e vivências das crianças, a observação participativa permitiu perceber que algumas lacunas poderiam estar sendo produzidas em relação aos usos dados à fotografia para o escopo documental produzido pela da escola. Na análise de conteúdo, os eixos de espaço e tempo deram origem às subcategorias "ambientes invisibilizados" e "momentos privilegiados", respectivamente. Estas lacunas ou "sombras", como foram categorizadas, poderiam ser produzidas pelas lentes e 
escolhas de quem fotografa, pois existiam situações no cotidiano da escola que se evitava mostrar, e a tarefa da análise consistiu na tentativa de identificá-las.

Algumas das escolhas sobre os processos aos quais se dá maior visibilidade pela fotografia na escola apareceram logo ao início do período de imersão, em 2018. Em entrevista, quando as gestoras responderam sobre as orientações dadas por elas às educadoras a respeito das fotografias que deviam ser produzidas, muitas delas abordaram suas preocupações éticas e estéticas, que indicavam que nem tudo o que acontece na escola deve ser publicizado. Nesse primeiro ano da pesquisa, a observação dos espaços coletivos também indicou lacunas em relação aos ambientes valorizados pela fotografia. A análise apontou que o planejamento das práticas de produção de registros fotográficos das vivências poderia estar privilegiando certas propostas em detrimento de outras. Em 2019, quando a observação participativa esteve focada no acompanhamento dos grupos de crianças de Pré-A e suas professoras, foi possível evidenciar o que era colocado sob as "luzes" e o que era mantido nas "sombras".

\section{1}

\section{Tateando no escuro}

Em 2018, durante a observação dos espaços de uso coletivo, não foi difícil perceber que nem todos os ambientes da escola eram contemplados pela fotografia. A categoria de análise que definiu os ambientes da escola considerados "invisibilizados" foi evidenciada a partir de sua coocorrência na análise de conteúdo, com outras duas categorias de análise: currículo e observação. No eixo "currículo", foram categorizados os usos pedagógicos que eram dados a cada espaço na prática e, também, a valorização e o reconhecimento dos espaços de aprendizagem que deveriam ser documentados com fotografia. No eixo "observação", avaliou-se se havia sistematização das práticas de observação das crianças e produção de registros fotográficos das aprendizagens e vivências delas naqueles espaços.

Percebeu-se que nem todos os ambientes escolares eram usados com fins educativos, em especial aqueles utilizados para atividades relacionadas ao cuidado, como espaços destinados à higiene e à alimentação das crianças banheiros e refeitório, respectivamente. Outros ambientes invisibilizados foram:

- espaços que, oficialmente, eram de uso restrito dos adultos - salas administrativas e cozinha; e 
- espaços de acesso e circulação sem usos definidos - recepção/ saguão de entrada.

Considerou-se que esses espaços ficavam à sombra, conforme indica a planta baixa ilustrativa da escola (Figura 21):
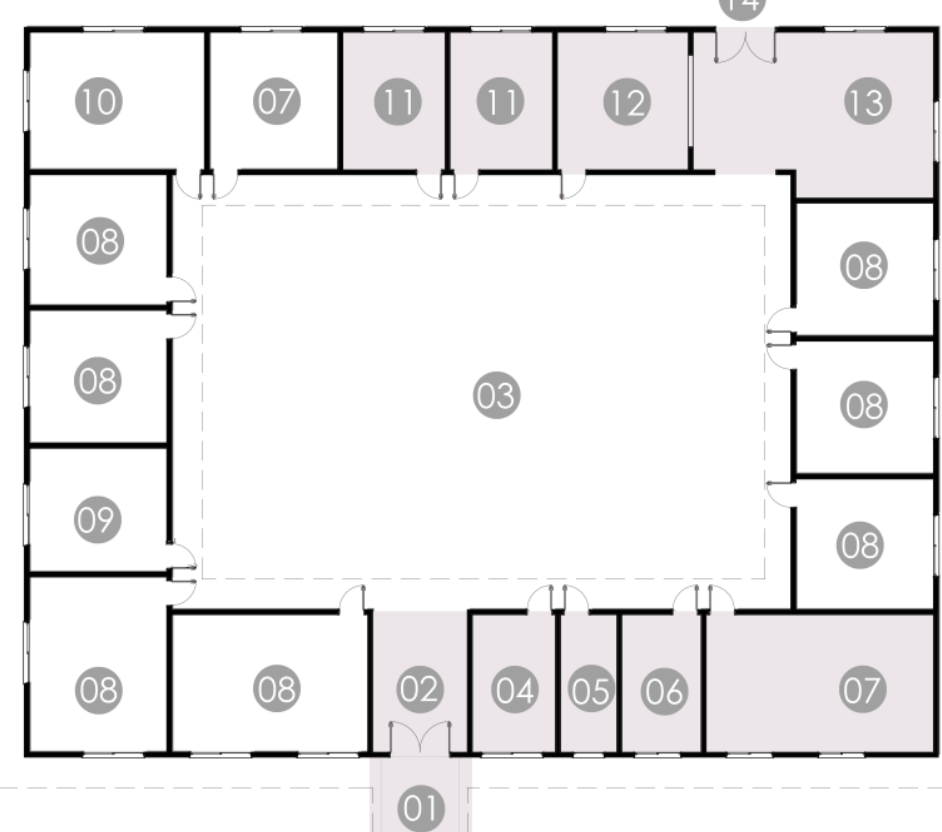
01 Acesso
05 Almoxarifado
09 Sala de informática 13 Refeitório
02 Recepção/saguão
06 Coordenação
(10) Sala de AEE
14 Parque Externo
03 Pátio interno
07 Sala professores
(1) Sanitários
04 Secretaria
08 Salas de aula
12 Cozinha

Figura 21 - Ambientes invisibilizados ${ }^{48}$ Fonte: Elaborado pela autora.

Os espaços eram, predominantemente, caracterizados de acordo com o uso para o qual haviam sido destinados. Assim, só eram documentados os espaços onde se desenvolviam propostas pedagógicas previstas no currículo da escola. Porém, na observação dos espaços de uso coletivo, identificou-se que nos espaços "à sombra" das lentes da fotografia, as crianças também experimentavam vivências significativas junto a seus pares e/ou com profissionais da escola, que não estavam previstas explicitamente como propostas pedagógicas nos projetos.

Esses espaços secundarizados foram entendidos na perspectiva de um

\footnotetext{
48 Esta é uma planta ilustrativa, não correspondendo às proporções originais do prédio da escola.
} 
“não-lugar”, que segundo a definição de Augé (2001), é um espaço intercambiável onde os sujeitos permanecem anônimos e que não possuem significado suficiente para serem considerados "lugares". Enquanto os espaços educativos ou "visíveis" criam uma relação social orgânica na dinâmica da escola, os "não-lugares" geram uma tensão solitária, vazios de significação.

A análise também mostrou que alguns dos "ambientes invisibilizados" poderiam ter grande potencial em relação aos registros fotográficos, podendo servir como cenário para exposições, caso dessem livre acesso ao acervo de fotos da escola, porém estavam sendo pouco ou raramente utilizados com esse fim.

A seguir, serão narradas e discutidas algumas vivências relacionadas à documentação com apoio da fotografia, observadas em três "ambientes invisibilizados" da escola: A. saguão de entrada; B. secretaria e C. refeitório.

\section{A. Saguão de entrada}

Em análise, considerou-se que o saguão de entrada e a recepção eram secundarizados, já que não se fazia uso pedagógico destes espaços na dinâmica da escola. Pelo saguão ser um ambiente de acesso, com fluxo esporádico de pessoas, dava-se pouca atenção às interações que aconteciam ali, tanto em relação aos visitantes, que ao chegarem à escola se dirigiam à secretaria, quanto às crianças, que nos momentos de entrada e saída interagiam nesse ambiente com adultos e/ou com os pares.

A entrada da escola é controlada por um guarda, funcionário de uma empresa terceirizada, que fica permanentemente em uma guarita. Quando uma pessoa chega à escola, é necessário aguardar em frente ao portão principal o atendimento desse funcionário, que solicita identificação e, em seguida, encaminha o visitante a um saguão de entrada. Neste hall, havia um mural de recados e uma frase em letras coloridas, que remetia ao projeto temático em vigência. O saguão de entrada mantinha-se limpo e organizado, o que parecia causar boa impressão às pessoas que ali chegavam.

Embora não houvesse barreira física limitando o acesso ao pátio interno e às salas, notou-se que, por parte dos adultos que entravam na escola, havia o costume de não ultrapassar o espaço do saguão de entrada. Em entrevista, a diretora comentou que "esse respeito que a comunidade tem com a escola foi sendo conquistado com muito esforço". Ela explica que, no início da gestão de sua equipe, em 2016, nem todos os pais/responsáveis pelas crianças compreendiam a solicitação de que, para garantia da privacidade das crianças e 
profissionais, não se dirigissem sem autorização às outras dependências da escola e que isso havia sido motivo de alguns conflitos, já superados.

Algumas situações observadas indicaram que o saguão de entrada da escola poderia ser um espaço com potencial para exposição da documentação com fotografia, conforme registrado no diário de campo.

Notas de campo da pesquisadora (novembro/2018)

(1) Enquanto eu observava o hall de entrada da escola, uma senhora, depois de se identificar para o guarda, pediu à secretária se poderia ir até a porta da sala de sua filha para ver as fotos expostas em um varal. Após o consentimento desta, a senhora foi até lá, observou as fotos com calma e voltou depois de alguns minutos.

(2) Uma visitante, ao chegar à escola, antes de ser atendida pela secretária, permaneceu no saguão por alguns instantes observando com detalhes os quadros decorativos e os avisos do mural.

Conforme chegam à escola, crianças, pais/responsáveis e comunidade escolar buscam na recepção algo que os aproxime do contexto da escola. O hall de entrada se mostra a quem chega como "cartão de visita", situando o trabalho que é desenvolvido na escola e apresentando os sujeitos que ali atuam. Caso houvesse uma organização específica desse espaço para a exposição das fotos, não seria necessário limitar isso aos varais próximos às portas das salas (espaço ao qual os visitantes não têm acesso).

\section{B. Secretaria}

Após observar a recepção da escola, o foco passou para os espaços administrativos, uma área restrita que engloba: secretaria/diretoria, coordenação, almoxarifado e sala dos professores. De acordo com a apresentação feita pelas gestoras ao início da pesquisa, esse seria um espaço ao qual as crianças não tinham acesso, mas isso se mostrou um pouco diferente durante a observação. Por diversas vezes, no acompanhamento da dinâmica de trabalho da equipe de gestão nesses espaços, chegaram professoras acompanhando crianças e solicitando auxílio da equipe para solucionar algum conflito ocorrido em sua sala. Diretora, vice-diretora e coordenadora revezavam-se entre si, de acordo com a disponibilidade, para atender a esses casos, que em geral estavam relacionados a comportamentos das crianças considerados inadequados pelas professoras que após tentativas frustradas de solução, demandavam medida mais contundente, que ficava a cargo das gestoras. 
Enquanto acompanhava a dinâmica de trabalho dos espaços administrativos da escola, chegou à secretaria uma professora, de mãos dadas com uma menina estava com as mangas da blusa molhadas e cabeça baixa. A professora disse que a menina havia ido ao banheiro e que não havia retornado à sala, pois ficou brincando com água na pia. Depois de dizer que precisava retornar à sala para acompanhar as demais crianças, a professora deixou a menina aos cuidados da diretora e saiu. A diretora conversou com ela e pediu que se comprometesse a não sair mais da sala sem autorização da professora, nem desperdiçar água brincando. Em seguida, as duas foram providenciar a troca de roupas para que a criança pudesse retornar à sua sala (Nota de campo da pesquisadora, novembro/2018).

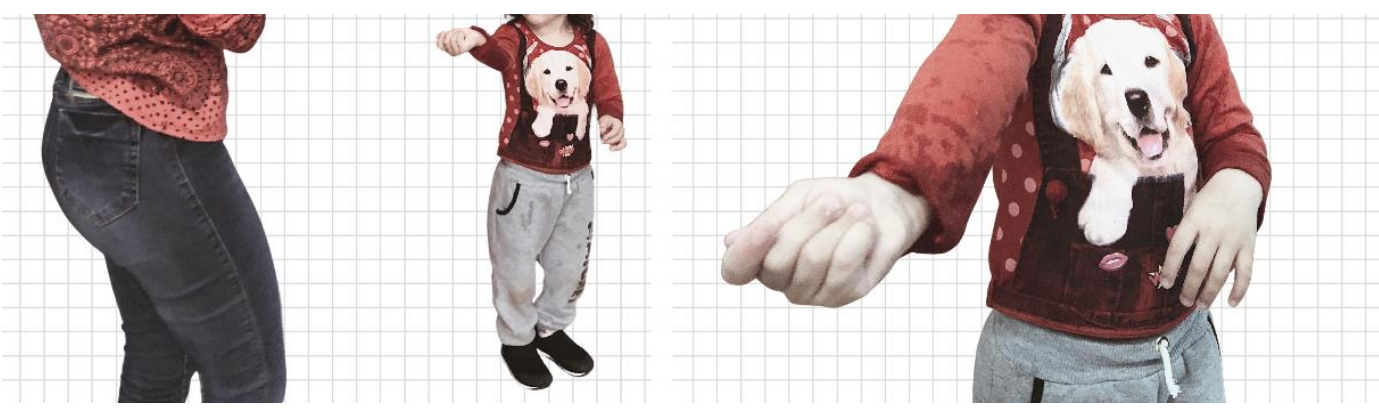

Figura 22 - Observação dos espaços administrativos ${ }^{49}$ Fonte: Acervo da autora.

Após o episódio narrado no diário de campo, iniciamos um diálogo com diretora, vice-diretora e coordenadora, a respeito dessas situações, em que as crianças visitavam os espaços administrativos, por solicitação de suas professoras. Debateu-se o motivo pelo qual esses momentos não são fotografados, em especial quando a criança chega à secretaria em decorrência de algum conflito que não tenha sido resolvido pela professora ou por um comportamento considerado inadequado. É provável que, em primeira instância, pareça óbvio que situações como essa não devam ser expostas ou registradas, para que se preserve a imagem da criança ou para evitar constrangimentos às educadoras. Havia, porém, um interesse em justamente provocar uma reflexão sobre o que se escolhe dar visibilidade com a fotografia e os momentos que devem ser documentados no trabalho realizado pela equipe de gestão.

As fotos tiradas por mim na secretaria foram mostradas à diretora e à coordenadora - exercício feito com frequência durante a pesquisa, para que as educadoras pudessem refletir sobre o que é visto na foto depois de terem vivenciado a situação na prática.

$49 \mathrm{Na}$ Figura 22, a diretora está de braços cruzados, diante de uma criança/menina com o braço esticado, indicando as mangas da blusa molhadas. 
Andressa (diretora/2018) - Na verdade, eu estava com vontade de rir, mas não queria mostrar isso para a criança, então fiquei bem séria e perguntei o que ela tinha "aprontado" no banheiro, mas ela só indicava a roupa molhada, não falou mais nada. $\mathrm{Na}$ hora eu estava envolvida na situação, não achei minha atitude exagerada. Mas agora, olhando essas fotos, percebo que minha figura pode ter intimidado ela. [...] Sempre que acontece alguma situação desse tipo, as professoras dizem que vão trazer as crianças para conversar com a "Dire". [...] Mas eu queria que ficasse claro que minha função na escola é de autoridade, e não de autoritarismo.

A fala da diretora mostra seu desconforto ao ver que na foto sua postura e expressão corporal podem ser interpretadas como uma atitude autoritária diante da criança. Segundo ela, quando se dirige às crianças, faz o esforço de mostrar um semblante sério, pois é a postura que as professoras esperam dela, mas diz que na verdade sentiu vontade de rir com a situação. Ainda assim, ela tem receio de que sua atitude seja interpretada de maneira equivocada a partir das fotos. Apesar de não ter expressado esse constrangimento enquanto vivenciava a situação, a ideia de transparecer excessivamente rígida nas fotos seria inadequada à sua função.

\begin{abstract}
Franciane (coordenadora/2018) - O fato de estar molhada depois de uma ida ao banheiro, representa a vontade que muitas crianças têm quando entram em contato com água. Mas, mesmo assim, existem momentos e lugares para isso. [...] Dá pra ver na foto que ela está ali, na sala da direção, para se explicar, ou melhor, mostrar o que aconteceu no banheiro. Ali ela foi questionada, ouvida e vista. "Ouvida" não seria a palavra... Pois ela apenas mostrou a roupa molhada...
\end{abstract}

A coordenadora da escola, que trabalhava em seu computador na ocasião em que a foto foi tirada, parece reformular sua interpretação sobre a situação a partir da leitura da imagem. Primeiro, ela diz que, na secretaria, a criança é "questionada, ouvida e vista", mas depois parece repensar, e então pondera que pelo gesto da criança na foto, é provável que ela não tenha sido ouvida como merecia.

Andressa (diretora/2018) - Existe uma função da direção que não está descrita em nenhum documento, que é a função de autoridade na escola. Quando acontecem situações em que as professoras entendem que as crianças precisam ser chamadas à atenção mais firmemente, logo se diz: "Olha que eu vou te levar para a diretora!". Nunca tive um perfil autoritário, mas quando assumi a direção, percebi que era algo que eu precisava me trabalhar, porque era isso que esperavam de mim. Pra chamar atenção de uma criança na educação infantil, pra "dar uma bronca", tem que que estar preparado em muitos sentidos, porque uma palavra mal escolhida pode não ser compreendida pela criança. Afinal de contas, as "artes" que as crianças fazem na educação infantil, são situações próprias da idade, mas em algumas situações, as professoras acham que precisa de uma atenção maior. Então, quando as professoras começaram trazer as crianças até a secretaria, eu percebi que eu não poderia mais fazer o que eu mais gostava, pegar as crianças no colo, conversar com uma a uma. Eu precisava ser outra pessoa como diretora. E, na EMEI Dom 
João A. Hoffmann, não sou só eu que cumpro essa função, mas também a coordenadora e a vice-diretora. Pra criança, não importa quem é diretora, coordenadora, ou quem é vice-diretora, quem está na secretaria é "dire": "dire" Andressa, "dire" Fran e "dire" Tchéssika. Então, não é nada confortável. Pelo lado da professora, pode ser que ela espere que você dê uma "bronca" de verdade e que a criança melhore o comportamento, mas a gente sabe que isso não vai acontecer, que muitas vezes a criança sai da secretaria e esquece tudo o que foi dito. Então, não é uma função que eu gostava de exercer, eu não me sinto bem. Eu não tenho essa postura tão rígida, que talvez seja o que os adultos esperam de uma diretora, sempre fui mais brincalhona. Eu sei que em escolas de ensino fundamental e ensino médio, são essas pessoas que assumem a postura de autoridade máxima, que resolvem os conflitos, mas o que é um conflito de criança? Isso precisa ser pensado em uma escola de educação infantil. O que se entende por "dar bronca"? Como "dar bronca" em uma criança? Que postura assumir? Nunca dei castigo ou medidas severas. Normalmente, eu cruzo os braços, faço uma cara mais fechada e converso com a criança, como na foto.

Entre os inúmeros aspectos importantes suscitados no depoimento da diretora, destacou-se sua constatação de que as crianças reconhecem os papéis desempenhados por cada profissional da escola. Na ocasião, chamei a atenção da equipe para a importância dessa relação estabelecida entre gestoras e crianças, reforçada a partir das interações que ocorrem nos espaços administrativos. Não seria mais fácil produzir estas reflexões se houvesse uma forma de documentar esses processos e problematizá-los durante as reuniões pedagógicas com as professoras? E a fotografia, não poderia contribuir com essa documentação?

As gestoras não chegaram a uma conclusão definitiva sobre como poderiam documentar sua prática no cotidiano dos espaços administrativos da escola. Para elas, a escolha dos processos a que se deve dar visibilidade com as fotos esbarra em questões éticas e morais sobre a exposição das crianças e dos adultos. Por outro lado, concordam que as fotos feitas na secretaria as tinham feito repensar sobre como elas próprias eram vistas pelas crianças e pelas colegas, professoras. Assim, assumem que quando a equipe gestora deixa de documentar as interações que ocorrem nos espaços administrativos, pode, ainda que inadvertidamente, fazer com que essas situações sejam mais facilmente esquecidas, deixando de serem problematizadas em âmbito pedagógico.

Os ambientes administrativos, a partir da análise, também se configuram como o principal espaço para acervo digital e físico de fotos, bem como para reprodução e impressão gráfica na escola. A secretaria concentra:

- computadores de uso administrativo;

- impressoras de uso da secretaria, gestão e professores; e

- álbuns com registros fotográficos de cada ano. 
Contudo, na dimensão de análise sobre os "ambientes invisibilizados" na escola, questionou-se sobre o acesso limitado que a comunidade, as famílias, as crianças e as próprias professoras têm a esses equipamentos e ao acervo de fotos. Algumas dessas questões puderam ser ressignificadas em 2019, conforme abordado mais adiante na pesquisa.

\section{Refeitório}

A observação dos espaços coletivos da escola finalizou na cozinha e no refeitório - ambientes que permitiram o registro de importantes vivências das crianças quando não estão na companhia dos adultos de referência. Em contrapartida, em relação aos usos pedagógicos dados à fotografia, esse foi o espaço considerado mais "invisibilizado", pois não houve situações registradas em observação, em relatos das educadoras e nos projetos temáticos, em que esse espaço fosse fotografado. Também não se identificou, durante a observação nesse espaço, que houvesse fotografias expostas em murais, como costumava acontecer nos corredores e portas das salas, por exemplo.

Ao elaborar o cronograma de imersão na escola, estabeleceu-se que a cozinha e o refeitório seriam observados em 2018, quando o foco estaria nos espaços coletivos e, de fato, esse cronograma foi cumprido. Entretanto, em 2019, durante o acompanhamento dos quatro grupos, o refeitório continuou sendo cenário para as observações. Isto porque, de acordo a organização da escola, as professoras costumam fazer quinze minutos de intervalo enquanto as crianças lancham e, nesse período, eu permanecia com estas crianças. Na ausência de suas professoras, as crianças se encorajavam a conversar e interagir de maneira peculiar, entre elas próprias, com as cozinheiras e, até mesmo, comigo - o que permitiu o registro de aprendizagens e vivências significativas que poderiam estar sendo pouco valorizadas, por não serem estimuladas nem documentadas pelas educadoras.

No prédio da escola, cozinha e refeitório se concentram em um mesmo setor, havendo uma janela com um balcão que conecta os dois ambientes. A cozinha é de uso restrito das funcionárias e o balcão que a interliga com o refeitório parece ter sido projetado para que as cozinheiras pudessem entregar o lanche às crianças, como ocorre em escolas que atendem a alunos maiores. Como na educação infantil as crianças são menores e não alcançam o balcão, o lanche é servido em recipientes de plástico, apoiados em uma mesa baixa e larga. As cozinheiras ficam ao lado da mesa, auxiliando as crianças e repondo o lanche, de 
acordo com a demanda (Figura 23).
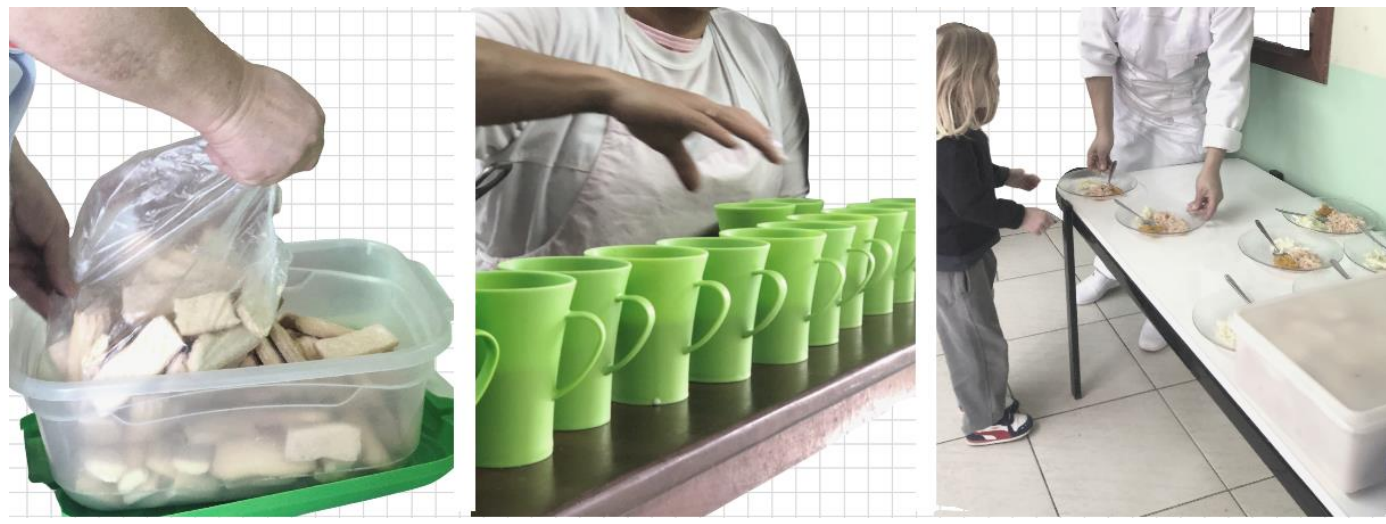

Figura 23 - Observação da hora do lanche Fonte: Acervo da autora.

Ao chegar à porta do refeitório com seu grupo, cada professora anunciava o cardápio do dia e a partir dali as crianças ficavam sob responsabilidade das funcionárias da cozinha. O lanche não é obrigatório e nem sempre as crianças estão dispostas a comer o que é oferecido em cada dia. Contudo, as funcionárias da cozinha costumavam incentivar as crianças para que ao menos experimentassem a comida, assumindo a responsabilidade pela garantia de que as crianças se alimentassem bem e evitassem desperdícios.

As três cozinheiras conheciam bem as crianças, chamavam-nas pelo nome, sabiam quais as preferências da maioria delas em relação às opções do cardápio e faziam questão de mostrar isso quando percebiam que estavam sendo observadas. É possível que a presença de uma pessoa estranha observando o espaço do refeitório as tenha provocado a demonstrar a importância de seu trabalho. Este, apesar de fundamental para a criação de hábitos alimentares e para apresentação e aceitação, pelas crianças, de alimentação de qualidade, goza de pouco reconhecimento no contexto educativo brasileiro, sendo em geral considerado menos relevante no âmbito das profissões escolares e, por essa razão, é também invisibilizado (Carvalho; Muniz; Gomes; Samico, 2008; Fernandes; Fonseca; Silva, 2014). Nesse sentido, na tentativa de mostrar que tinham uma relação estreita com as crianças, algumas atitudes das funcionárias pareciam pouco espontâneas e excessivamente rígidas, em especial quando insistiam para que as crianças comessem, para que fizessem silêncio e não conversassem com os colegas. Ou quando notavam que as crianças estavam brincando ou demorando a lanchar e chamavam a atenção e as trocavam de 
lugar ${ }^{50}$

No entanto, ainda que as cozinheiras mantivessem certo controle sobre o comportamento das crianças no refeitório, a hora do lanche se apresentou para a pesquisa como um momento de experimentação para as crianças, inclusive em relação à fotografia.

Enquanto as crianças se serviam, lanchavam ou interagiam entre si, passei a fotografá-las. Com isso, algumas crianças, quando percebiam que eu estava com o celular em mãos, tentavam atrair a atenção para si: "Você já tirou uma foto do meu prato? Já comi tudo!". Elas pareciam supor que eu tirava fotos para "vigiálas" ou controlar quem estava se alimentando bem, para depois comunicar a suas professoras (de fato, algumas professoras perguntavam como as crianças tinham se comportado na sua ausência). Algumas comiam rápido, como se estivessem cumprindo com uma obrigação e, depois de avisarem que tinham terminado, aproveitavam os minutos restantes para brincar com os colegas, até que as professoras retornassem do intervalo para buscá-las.

Interessante perceber que, apesar de "prestarem conta" aos adultos, mostrando seus pratos como comprovação de que tinham "comido tudo" ou "raspado o prato", as crianças não pareciam ficar acuadas ou intimidadas em relação a minha presença fotografando ou às cozinheiras controlando a disciplina no refeitório. Ao invés disso, pareciam convictas de que basta contentar os adultos, fazendo o que eles esperam, para ter alguns minutos de liberdade e poder brincar. Assim, uma a uma, as crianças mostravam o prato, perguntavam se eu já tinha tirado foto (algumas pediam para conferir a foto no visor do celular) e, em seguida, voltavam ao seu lugar à mesa para brincar com os colegas que também tinham terminado de lanchar.

Uma das brincadeiras preferidas das crianças nesses minutos após o lanche era de se abaixar e se esconder, com a cabeça embaixo da mesa - como se desafiassem os adultos, dizendo: "Aqui vocês não podem nos ver!" ou como se dissessem a mim: "Aqui você não vai nos fotografar!" "51.

\footnotetext{
50 Com exceção da equipe de gestão 2016-2018, os funcionários da escola não participaram diretamente da pesquisa. Ao início da observação participativa na cozinha e no refeitório da escola, apresentei-me às cozinheiras, explicou os objetivos da pesquisa e pediu informalmente consentimento para observar as crianças no ambiente de trabalho delas. Tendo havido consentimento, garantiu-se a preservação de seu anonimato e de seus rostos em imagens que viessem a ser exibidas na pesquisa. Por este motivo, situações que envolviam a atuação direta destas funcionárias não foram narradas na pesquisa, evitando-se constrangimento por parte delas a partir da identificação de características pessoais que fossem citadas.

51 Semelhante aos bebês, que escondem o rosto ou os olhos com as mãos, acreditando que não estão sendo vistos pelos adultos.
} 
Inicialmente, procurou-se não interferir ou interromper as brincadeiras das crianças no refeitório. Quando elas se escondiam embaixo da mesa, aquele espaço era respeitado como um território exclusivo delas. Então, o que acontecia ali não era fotografado. Ao invés de reprová-las, eu sorria ou piscava para elas discretamente, como um gesto de aprovação à brincadeira, que selou um código de confiança entre as partes. Com o vínculo estreitado, as crianças iniciaram tentativas de me incluir na brincadeira de "esconde-esconde" improvisada no refeitório. Depois de lancharem, sentadas à mesa, encaravam-na sorrindo até que conseguissem contato visual e, quando conseguiam, escondiam-se rapidamente com a cabeça embaixo da mesa. A partir daí pareceram mudar o tom do desafio para: "Não quer ver o que estamos fazendo embaixo da mesa?". Assim, várias fotos foram feitas, a convite das crianças (Figura 24).
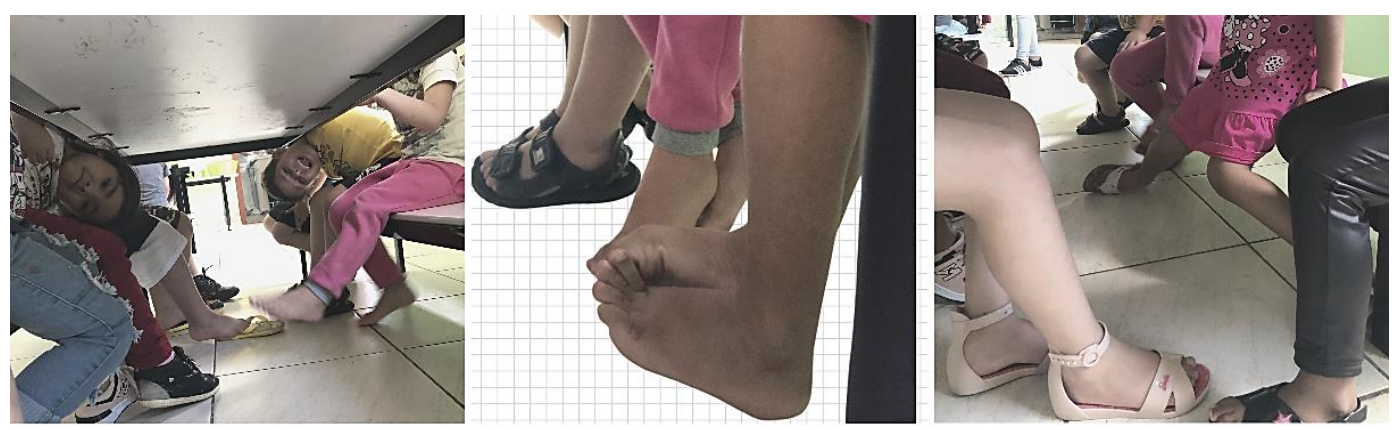

Figura 24 - Documentando a hora do lanche Fonte: Acervo da autora.

As reconceitualizações propostas pela Sociologia da Infância (Sarmento; Pinto, 1997; Soares; Sarmento; Tomás, 2005; Sarmento, 2008; Corsaro, 2011) têm sido apropriadas pelos pesquisadores na compreensão da infância como uma categoria histórica, social e estrutural, em que a criança é constituída como sujeito de direitos e como produtora de cultura. Estudos filiados a essa perspectiva denunciam a restrição da escola ao brincar, que costuma ser autorizado à criança em poucos momentos. No ensino fundamental, os espaços/tempos para o brincar são cada vez mais restritos, obrigando as crianças a encontrarem oportunidades em momentos aligeirados, como é o caso do recreio (Delalande, 2001). $\mathrm{Na}$ educação infantil, os espaços/tempos pensados para o brincar não são tão restritos, pois embora não haja a prática do recreio, há na rotina mais oportunidades para brincadeiras, na interação com os pares - a exemplo das idas diárias dos grupos ao parque interno ou externo. Ainda assim, mesmo no parque, 
as crianças estão a todo momento sob vigilância das professoras ou das auxiliares.

Conforme indicou a observação, a lógica da vigilância do adulto só era burlada pelas crianças em espaços e momentos secundarizados, como ocorreu no refeitório. Entre o tempo em que terminavam de lanchar e enquanto aguardavam as professoras voltarem de seu intervalo, as crianças criavam várias oportunidades para interagir sem a interferência dos adultos. Nesta perspectiva, o refeitório se apresentou como importante espaço de produção da cultura de pares (Corsaro, 2009; 2011), produzida pela liberdade e continuidade das relações que se estabelecem entre as crianças. Corsaro (2009, p. 32) define cultura de pares como "um conjunto estável de atividades ou rotinas, artefatos, valores e interesses que as crianças produzem e compartilham na interação com seus pares".

Destarte, a análise dos "espaços invisibilizados" foi um importante indicativo sobre a necessidade de que os adultos (tanto educadores quanto pesquisadores) estejam atentos a todos os sinais que as crianças transmitem, indicando se há ou não autorização para fotografá-las.

Destarte, a análise dos "espaços invisibilizados" foi um importante indicativo da necessidade de que os adultos estejam atentos aos sinais que as crianças transmitem relacionados à permissão para serem fotografadas. Na observação do refeitório, foi necessário conquistar a confiança delas para que consentissem e até solicitassem o registro fotográfico de seus momentos de brincadeira após o lanche. Assim, é fundamental perceber que as escolhas dos processos que se tornarão visíveis pelas lentes da fotografia não podem partir apenas dos adultos e que é preciso levar sempre em conta a opinião das crianças. Conforme debatido na sessão metodológica da pesquisa, esse consentimento por parte das crianças requer a utilização de estratégias que tornem possível que elas se expressem por meio de múltiplas linguagens, em um processo de comunicação que demanda sensibilidade apurada e disponibilidade constante de escuta por parte dos adultos. 


\section{2 \\ Quem tira as fotos?}

A resposta para a pergunta sobre quem fotografa, conduz análise a uma reflexão sobre os adultos responsáveis pelos processos de observação e produção de registros das crianças na escola. Nesse sentido, a pesquisa-ação aproximou meu trabalho, como pesquisadora, ao das educadoras, em relação à documentação com fotografia produzidas no contexto da educação infantil. As professoras, quando estavam no papel de fotógrafas, se tornavam investigadoras de seu contexto, da mesma forma que eu, como pesquisadora; e eu, no papel de fotógrafa, precisava sistematizar as práticas de observação, levando em conta aspectos éticos e estéticos em relação às crianças e aos outros adultos, como faziam as professoras. Tanto na pesquisa quanto na prática docente, é preciso interpretar os recortes da realidade representados nas fotos, levando em conta as subjetividades de outros expectadores, para construir sentido à documentação.

Diferentes estudos têm mostrado que 0 ato de fotografar e interpretar as imagens pode contribuir para que o educador construa um trabalho sistemático de investigação a partir de sua prática (Moran, 2009; Malavasi; Zoccatelli, 2019).

Gambetti \& Gandini discorrem sobre os processos que englobam a atitude de pesquisa necessária ao adulto que se propõe a fotografar enquanto observa as crianças. Nesse processo, destacam o valor que tem o tempo, sendo imprescindível haver disponibilidade para conectar e construir processos de consciência recíproca e para avaliar as aprendizagens que se desenvolvem de maneira respeitosa e autêntica.

Os professores afrouxam o tempo e usufruem do tempo. Eles têm a responsabilidade o direito ao tempo para refletir e questionar o que está acontecendo, e também para explorar com as crianças quais passos compartilhados devem ser dados (Gambetti; Gandini, 2020, p. xii ${ }^{52}$ ).

Nesta perspectiva, a fotografia pode atribuir instrumentalidade à pesquisa e investigação no cotidiano do educador. Quando assume a tarefa de documentar com fotografia, o educador-investigador pode atuar a partir de três principais funções: a função representativa, a reflexiva e a epistemológica, conforme o detalhamento do Quadro 11.

\footnotetext{
${ }^{52}$ Gabetti \& Gandini (2020), paginação em formato E-pub/Kindle.
} 


\begin{tabular}{|c|c|c|}
\hline Funções & Principais características & Pesquisa e investigação \\
\hline $\begin{array}{c}\text { Função } \\
\text { Representativa }\end{array}$ & $\begin{array}{l}\text { Remete ao conceito de múltiplas } \\
\text { interpretações que as imagens pode } \\
\text { assumir - de acordo com o contexto em } \\
\text { que são produzidas e a bagagem } \\
\text { cultural de quem as interpreta. }\end{array}$ & $\begin{array}{l}\text { Nas imagens é possível encontrar o } \\
\text { significado atribuído pelo educador no } \\
\text { ato em que tirou a foto e o que é atribuído } \\
\text { pelo olhar pessoal do expectador. }\end{array}$ \\
\hline $\begin{array}{l}\text { Função } \\
\text { Reflexiva }\end{array}$ & É vivida totalmente pelo educador. & $\begin{array}{l}\text { O educador encontra no ato de fotografar } \\
\text { uma ligação entre o seu pensamento e o } \\
\text { objeto (ou o sujeito) fotografado. }\end{array}$ \\
\hline $\begin{array}{c}\text { Função } \\
\text { Epistemológica }\end{array}$ & $\begin{array}{l}\text { Refere-se aos ganhos em termos de } \\
\text { conhecimento que a fotografia oferece ao } \\
\text { educador. }\end{array}$ & $\begin{array}{l}\text { Com o ato de fotografar, o educador tem } \\
\text { a possibilidade de ampliar } \\
\text { conhecimentos, de partilhar com colegas } \\
\text { e de codificar e decodificar significados. }\end{array}$ \\
\hline
\end{tabular}

Quadro 11 - Instrumentalidade da fotografia ao educador-investigador Fonte: Moran, 2009; Malavasi; Zoccatelli (2019), adaptado pela autora.

$\mathrm{Na}$ análise de conteúdo, as três funções de instrumentalidade da fotografia ao educador-investigador - representativa, reflexiva e epistemológica - foram tomadas como referência na interpretação dos conteúdos categorizados nos eixos temáticos: "intencionalidade", "observação", "planejamento" e "avaliação".

No que diz respeito às funções representativa, reflexiva e epistemológica, a análise indica que a prática das professoras como fotógrafas está em constante transformação e desenvolvimento. Nas falas a seguir, as professoras traçam seu percurso individual com a fotografia, motivadas a pensarem sobre como essa experiência pessoal vinha se refletindo em sua prática docente.

Andressa (professora/2019) - Não nasci sabendo tirar foto, foi um processo. Hoje as minhas fotos são muito melhores do que as que eu tirava no ano passado. Sempre gostei muito de fotografar, mas para falar a verdade, mais do que fotografar, eu gosto de revelar as fotos. Em casa, tenho muitos álbuns, porque gosto de ver a foto impressa. Nos meus álbuns de família, sempre coloco data nas fotos. Penso sobre aquele momento e depois escrevo o que representou para mim. Hoje, eu tento viver isso na escola. Funciona assim: no final de cada semana, abro as fotos das crianças no computador e penso muito bem sobre tudo o que eu vejo na foto.

Franciane (professora/2019) - Com bastante sinceridade, nunca fui muito "da fotografia". Na verdade, o despertar maior para a fotografia na minha prática começou depois que eu assumi a coordenação pedagógica, em 2016, quando eu comecei a visualizar as fotos com outro olhar, prestando mais atenção nos detalhes.

Tchéssika (professora/2019) - Gosto muito de fotografar. Gosto de me fotografar quando estou em casa. $E$ acho muito importante fotografar quando estou na escola. Mas, acho que a forma que estamos fotografando agora é melhor do que a forma que fazíamos antes, porque antes ninguém parava pra pensar sobre as fotos.

Inajara (professora/2019) - Sempre gostei muito de tirar foto em casa, e na escola é diferente. (...) Nos desenhos que as crianças fazem no Pré-A, já aparecem formas definidas, (...) que a fotografia vai me ajudar a compreender. Quando eu olho só o desenho, é diferente de olhar várias fotos da criança. Com a foto eu compreendo 
melhor o que está acontecendo naquele ambiente, se a criança realizou tal atividade, de que maneira ela participa, com que material está brincando.

Parte das professoras informou que em âmbito pessoal/familiar já tinham o hábito de fotografar, contudo, admitem que não havia tanta intencionalidade ou reflexão sobre esse gesto, colocando-se em um papel de quem está aprendendo a fotografar. Todas concordam que na escola as discussões sobre a fotografia, embora recentes, vinham contribuindo para que fotos com mais qualidade fossem produzidas.

Identificando-se que as educadoras se colocam na posição de aprendizes, e assumem sua constante transformação, a análise aponta que, para uma interpretação mais assertiva de suas fotos, é necessário que se avalie o contexto em que elas são produzidas, levando em conta que os sentidos interpretativos das imagens são intercambiáveis e multifacetados (Sontag, 2004; Ibañez, 1986; Barthes, 1984). Assim, o que é representado a partir das fotos também se altera, conforme as crenças e concepções pedagógicas das professoras vão mudando. Contudo, os significados atribuídos às fotos não dependem exclusivamente do olhar de quem fotografa, mas da interpretação de todos os expectadores: dos pais/responsáveis, de outras educadoras da escola e da comunidade em geral.

\section{3 \\ Que criança se quer comunicar?}

Para que se possa saber que imagem da criança as educadoras da escola desejavam comunicar através de suas fotos, é necessário que se esclareça de que infância (ou infâncias) estamos tratando. Para isso, traçamos um percurso histórico da construção social da formação de um sentimento ou de uma visão de infância, até chegarmos às possíveis imagens da criança apropriadas pelas educadoras.

Concepções de infância e de criança, tal como conhecemos hoje, nem sempre existiram. Sabemos, a partir das contribuições de Ariès (1981) sobre a história social da criança e da família, que por muito tempo as crianças ocuparam uma posição secundária na sociedade ocidental. Representações artísticas e iconográficas da Europa medieval narram um contexto em que as crianças eram consideradas "pequenos adultos" ou sujeitos em transição, até a completude de sua maturidade física e psíquica. Apenas com a superação do medievo e com a industrialização da sociedade ocidental é que se inicia um longo processo de 
reconhecimento da infância, até que se chegasse a representações mais próximas da criança como se concebe na contemporaneidade.

Ainda que não haja uma visão consensuada de infância, as crianças não são mais vistas como adultos em miniatura, mas isto não significa que essa ideia tenha sido totalmente superada ou que se tenha chegado a um novo e definitivo conceito. Vivemos em contato com múltiplas concepções de infância e criança, construídas através de imagens que circulam e coexistem no imaginário social. $A$ ascensão das mídias contemporâneas tem facilitado a ampla divulgação da imagem da criança, acendendo um alerta sobre os limites desta exposição e sobre o quanto a televisão, o mercado editorial e as mídias eletrônicas têm contribuído para a manutenção de imagens de uma infância estereotipada (Steinberg; Kincheloe, 2001; Buckingham, 2000) e para a distorção da imagem infantil, tornando as crianças

(...) objetos de consumo e divertimento, instrumentalizados, ridicularizados, muitas vezes expropriados do seu próprio corpo e privados dos seus pensamentos e da sua identidade enquanto pessoas (Malavasi; Zoccatelli, 2019, p. 69).

No Brasil, a dificuldade de constituição de uma imagem da criança que se aproxime mais da realidade pode ser ainda maior, pela deslegitimação e invisibilização das trajetórias das crianças pobres e negras, ou pelo fato de que os poucos relatos deixados a respeito das crianças não foram feitos pelas próprias ou por suas famílias, o que pode ter provocado uma visão distorcida da criança brasileira (Rizzini, 2007; Del Priore, 2000; Venâncio, 1999; Marcílio, 1998). Assim, o desafio pela definição da imagem das infâncias no Brasil refere-se à

realidade vivenciada pelas crianças e suas infâncias em diferentes espaços e tempos; à presença de crianças na construção e produção do território brasileiro; aos diferentes lugares ocupados pelas crianças numa mesma época e sociedade; à existência de várias infâncias e não de uma única, como tem sido comum nos estudos e olhares direcionados às crianças (Lopes, 2008, p. 67).

Somente a partir dos anos 1980, o Brasil começou a criar legislações para atendimento das necessidades das crianças, com políticas de reconhecimento e garantia de seus direitos (Vasconcellos, 2005; Kuhlmann Jr., 1998), consideravelmente atrasado em comparação a outros países ocidentais ${ }^{53}$. Nos

53 QVORTRUP, Jens. A infância na Europa: novo campo de pesquisa social. CEDIC, Insituto de Estudos da Criança. Braga: Universidade do Minho, 1999. 
documentos norteadores da educação infantil, a imagem da criança vem se modificando, evoluindo de acordo com as concepções de infância subjacentes às propostas que foram sendo elaboradas.

O Referencial Curricular Nacional para a Educação Infantil (RCNEI), de 1998, representou um avanço para a época, porém, era mais como uma orientação dos conteúdos e objetivos de aprendizagem e não fazia a criança e sua identidade o foco principal. Já as Diretrizes Curriculares Nacionais para a Educação Infantil (DCNEI), de 2009, já mostram um avanço na direção de colocar a criança em foco e serviram como um uma fundamentação teórica para a Base. Nas DCNEI, a atenção já estava voltada para a criança, e o documento reforça a importância do aluno ter acesso ao conhecimento cultural e científico, assim como o contato com a natureza, preservando o modo que a criança situa-se no mundo. As DCNEI colocam o foco nas interações e na brincadeira como eixos estruturantes do currículo, além de considerar os princípios éticos, políticos e estéticos que deveriam nortear a produção do conhecimento nas escolas infantis. Outro ponto a ser observado é o marco conceitual da relação entre o cuidar e o educar das DCNEI, algo que a Base valida e reforça (Trevisan, 2018, p. 17-18).

O Quadro 12 destaca as mudanças das concepções de criança presentes nos principais documentos que têm orientado a prática das instituições brasileiras de educação infantil: o RCNEI (Brasil, 1998), as DCNEI (Brasil, 2009a) e a BNCC (Brasil, 2017).

\begin{tabular}{cl} 
Documento & \multicolumn{1}{c}{ Como a criança é vista? } \\
\hline RCNEI & \multicolumn{1}{c}{$\begin{array}{c}\text { Concepção de criança } \\
\text { Foco está no desenvolvimento integral } \\
\text { da criança, mas ela ainda é vista como alguém que responde aos } \\
\text { estímulos dados pelos adultos (no caso da escola, os } \\
\text { professores). }\end{array}$} \\
& $\begin{array}{l}\text { Amplia o olhar sobre a criança, considerando as interações } \\
\text { sociais como condições essenciais para o aprendizado. Ao } \\
\text { mesmo tempo, a criança está no centro do processo de }\end{array}$ \\
aprendizagem, como sujeito das diferentes práticas cotidianas. \\
(BRASIL, 2009) & $\begin{array}{l}\text { Trata a criança com toda complexidade e potência e situa a } \\
\text { Educação Infantil em relação ao desenvolvimento de princípios } \\
\text { éticos, estéticos e políticos. }\end{array}$ \\
& $\begin{array}{l}\text { Reforça a visão da criança como protagonista em todos os } \\
\text { contextos de que faz parte: ela não apenas interage, mas cria e } \\
\text { modifica a cultura e a sociedade. }\end{array}$ \\
\hline BNCC &
\end{tabular}

Quadro 12 - Como a criança é vista?

Fonte: Trevisan (2018), adaptado pela autora. 
Com esse recorte das concepções de infância presentes nos documentos oficiais, percebemos que a BNCC representa uma conquista aos direitos das crianças, reconhecendo a agência e o protagonismo delas como produtoras e transformadoras de cultura. Ainda assim, o campo de estudos da Geografia da Infância nos alerta para o fato de que, mesmo que as crianças estejam presentes em registros de imagens ou em documentos (como é o caso da BNCC), as infâncias ainda se apresentam marcadas por suas invisibilidades (Lopes, 2008).

Malaguzzi (1994) dizia que as pessoas têm dentro de si imagens diferentes da criança, dependendo das experiências e das relações que cada um estabelece com crianças ao longo da vida. Esta imagem, particular e subjetiva, leva o adulto a se comportar de determinada maneira com as crianças - orienta a condução de uma conversa, a qualidade da escuta e da observação. Entretanto, é muito difícil que o adulto aja de maneira contrária à imagem interna sobre criança que ele já tem estabelecida. Por exemplo, quando um educador tem uma imagem cristalizada de que meninos e meninas são muito diferentes uns dos outros, é provável que ele estabeleça relações também distintas em suas interações com cada um dos gêneros.

Para compreender as concepções das professoras da escola pesquisada acerca da criança, foi perguntado a elas, em entrevista, se havia algum cuidado especial com as crianças na produção das fotografias. Essas falas foram analisadas a partir da categoria "exposição da criança", em que se buscou compreender qual é a imagem das crianças que as educadoras pretendem comunicar. Nas respostas, as educadoras expressaram cuidados que elas tomam no ambiente em que a foto é produzida, indicando que esses aspectos poderão influenciar na imagem da criança representada. Elas dizem que, quando estão fotografando, precisam estar atentas a tudo que acontece no ambiente, observando inclusive as crianças que estão ao redor, que não estão sendo diretamente focadas na foto. Com isso, conseguem evitar que alguma criança seja exposta de maneira inadequada, aparecendo no plano de fundo.

A maioria das professoras informou estar atenta às necessidades e direitos das crianças com relação à privacidade, respeito às opiniões delas, escolha de ângulos mais adequados para assegurar o registro de vivências pedagógicas específicas e espontaneidade e para evitar exposição de crianças em situações desconfortáveis, como indica a fala seguinte. 
Tchéssika (professora/2019) - Algo que eu me preocupo muito é que a foto seja feita em um momento espontâneo, um momento que foi realmente vivido e significativo pra criança. Nós tentamos não "dirigir" a fotografia, não queremos que a criança faça uma pose. (...) Antes nós tirávamos foto de forma muito mecânica. Parava tudo, a criança parava e a gente tirava a foto. Agora, se a criança está brincando, a gente não pede pra ela parar e olhar pra foto. Eles continuam brincando e a gente vai fotografando (Figura 25).
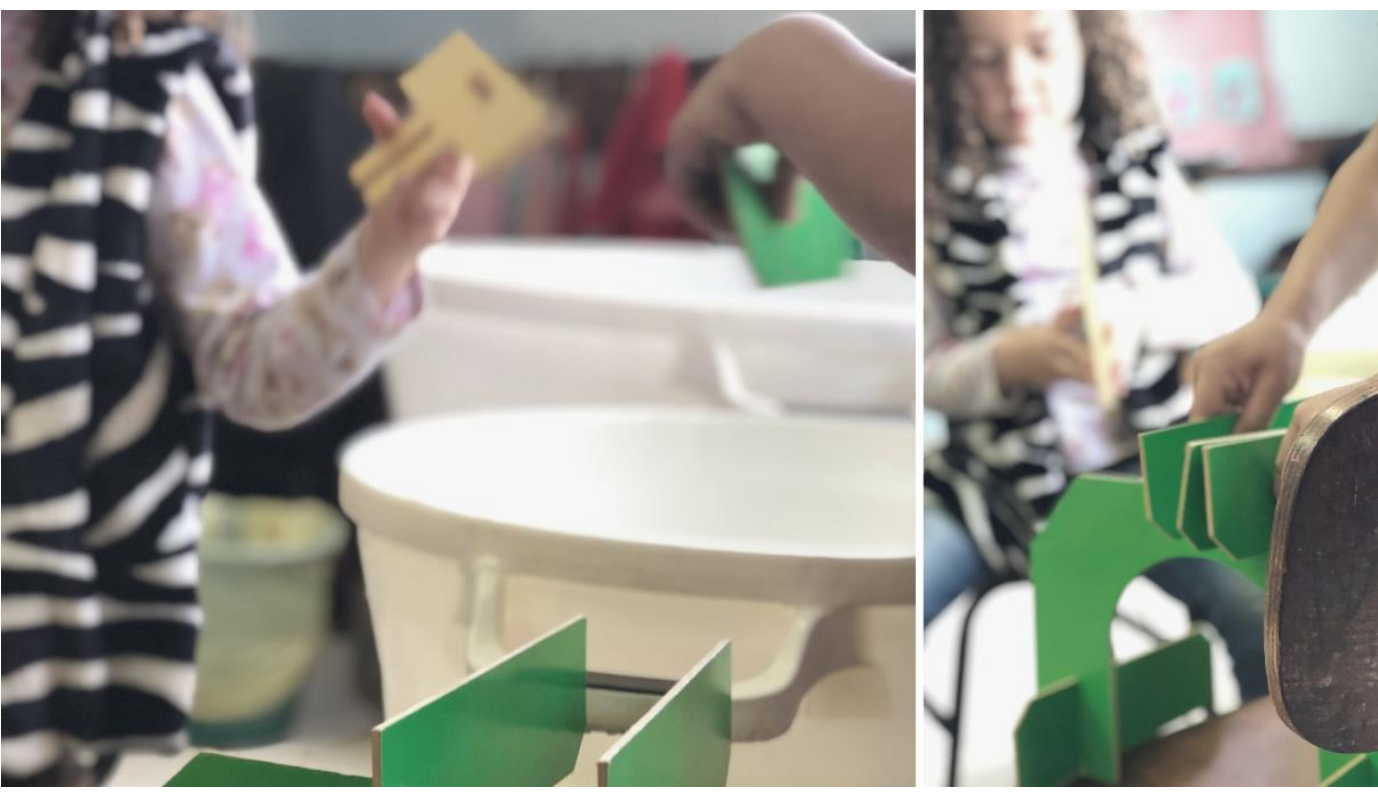

Figura 25 - Fotografando em momentos de espontaneidade Fonte: Acervo da autora.

A preocupação das educadoras com a exposição das crianças na fotografia, também foi percebida durante a observação participativa. Em situações conflituosas, em especial quando as crianças choravam, disputavam um brinquedo ou havia algum desentendimento, a conduta das educadoras era interromper o momento fotográfico e retomá-lo apenas quando a situação fosse resolvida, quando o grupo voltava à tranquilidade.

Outro aspecto que se destaca na fala das educadoras é elas acharem importante que haja espontaneidade por parte das crianças. Parecem concordar entre si que a foto precisa mostrar uma criança real, evitando que se construa um cenário artificial nas fotos. Elas dizem que preferem fotografar os momentos em que as crianças estão brincando e interagindo entre si, sem que se precise interromper esses momentos ou pedir para que as crianças façam poses orientadas.

Para Malaguzzi (1994), as imagens que o educador possui da criança, também se refletem no ambiente educativo que se constrói. Há diferença entre o ambiente construído com base em imagens pré-estabelecidas e estereotipadas e 
o ambiente construído com base na criança real, que está diante do educador - a partir das vivências e aprendizagens construídas de forma cooperativa. Quando o educador se permite construir um ambiente a partir da qualidade e da quantidade de interações com as crianças, há maior possibilidade de que isso se reflita na imagem de criança que ele terá.

Quando as educadoras se propõem a garantir que a foto se aproxime ao máximo da vivência real das crianças, estão se comprometendo com uma documentação que comunica uma imagem da criança como protagonista de sua narrativa. Assim,

[...] documentar significa também assumir a responsabilidade de oferecer um outro ponto de vista sobre a infância, um olhar mais autêntico e respeitoso, que restitui valor, dignidade, verdade e riqueza às crianças e a quem delas cuida, em família e nos serviços (Malavasi; Zoccatelli, 2019, p. 69).

Documentar, nesta perspectiva, significa desafiar os discursos dominantes e desconstruir estereótipos e imagens distorcidas da criança, construindo uma pedagogia satisfatória do ponto de vista moral e crítico, mas também agradável do ponto de vista estético (Dahlberg; Moss; Pence, 2003). Com escuta de qualidade e observação atenta das crianças, a documentação pedagógica pode ser o instrumento que servirá como ponto de partida para uma prática mais crítica e reflexiva.

\section{4}

\section{Como e quando se fotografa?}

Na observação dos espaços coletivos, em 2018, nem todos os ambientes compartilhados foram avaliados como invisibilizados ou à sombra. Alguns desses espaços, em que se punha "luz" pelas lentes da fotografia, possuíam diferentes usos, dependendo das propostas que ali eram desenvolvidas. O pátio interno, por exemplo, era utilizado para multifunções. $\mathrm{Na}$ metade à esquerda, ficava um parque com brinquedos plásticos. Na outra metade, além de uma brinquedoteca improvisada, com jogos e materiais não estruturados, as professoras costumavam deixar um espaço livre para a realização de atividades psicomotoras. Todos esses momentos eram fotografados, porém, para que se pudesse descobrir a que processos se escolhia dar visibilidade com a fotografia, foi necessário compreender o que era mais valorizado dentro do planejamento da escola, os momentos privilegiados no currículo. 
Entre os usos atribuídos ao pátio interno, destacaram-se como momento privilegiado as vivências de integração dos grupos de cada turno - que eram pensadas pela coordenação da escola ou mesmo proporcionadas pela Secretaria de Educação. As propostas de integração costumavam marcar o início ou o encerramento de um projeto, com brincadeiras, musicalização, teatro, exibição de filmes ou narração de histórias. As professoras participavam junto das crianças e os registros fotográficos dessas ações coletivas ficavam a cargo da equipe gestora. Em entrevista, a coordenadora pedagógica confirma que ela, diretora ou vice-diretora se organizavam em parceria para produzirem registros desses momentos e permitirem que as educadoras pudessem interagir verdadeiramente com as crianças, observá-las e escutá-las de forma efetiva.

Em outubro de 2018, ao início do período de observação dos espaços coletivos, a escola promoveu a apresentação teatral de uma peça infantil, dinamizada por um grupo de teatro amador da cidade. As crianças foram conduzidas ao pátio interno, onde havia um palco improvisado, e orientadas a sentarem ao chão, organizadas em fileiras. Minutos após o início da apresentação, vice-diretora e coordenadora se aproximaram, trazendo consigo câmeras fotográficas e seus celulares para fotografar a vivência. A equipe circulou ao redor do grupo de crianças, buscando diferentes ângulos para registrar o momento (Figura 26). 

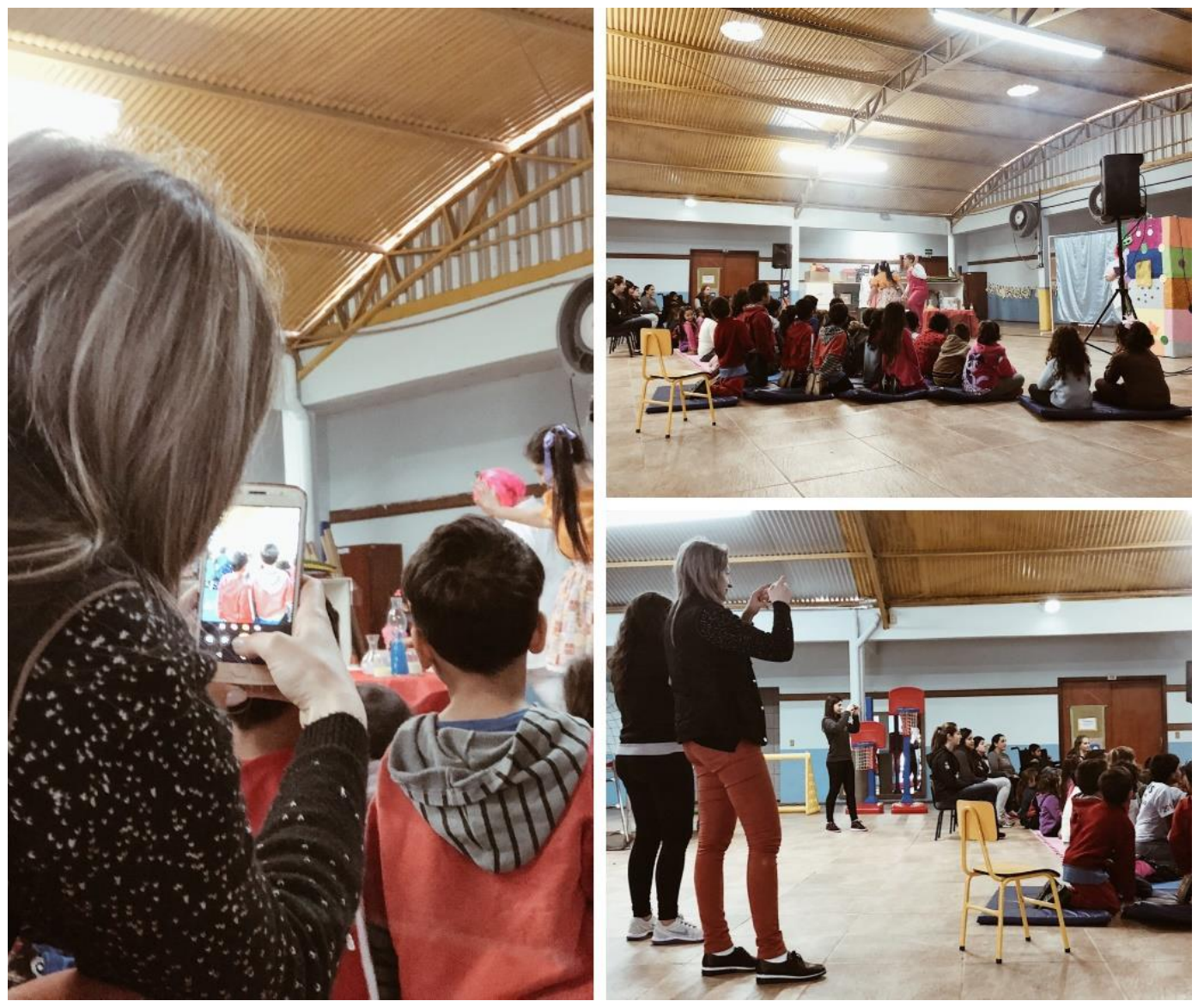

Figura 26 - Documentando vivências de integração Fonte: Acervo da autora.

$\mathrm{Na}$ análise, as propostas de integração foram consideradas "momentos privilegiados", pois possuíam destaque no currículo da escola e eram fotografadas de forma sistemática. As fotografias produzidas nesses momentos, em geral, serviam para a produção de memória da escola. As fotos selecionadas e impressas eram organizadas para compor o álbum da escola.

Andressa (diretora/2018) - No álbum, a gente se detém às "atividades principais" ou "relevantes" que a escola desenvolveu dentro de um projeto, seja em um momento com as crianças, com os pais ou em formação com as professoras. Tudo isso de "mais importante" que vai acontecendo durante o ano, a gente vai escrevendo 'o que foi e a data que foi', pra que fique como registro.

O álbum, portanto, é um artefato em que a escola documenta esses momentos considerados de maior relevância. A preocupação das gestoras, conforme demonstra a fala da diretora, é de que se produzam registros destas "atividades principais" nos projetos, para que se produza memória do que ocorreu na escola em cada ano. 
Em 2019, quando a observação esteve focada nos quatro grupos de Pré-A, perguntou-se em entrevista às professoras em que momentos elas fotografavam para documentar processos de aprendizagens das crianças. As respostas são semelhantes, e, em geral, remetem a situações extraordinárias, fora do padrão, a exemplo de uma educadora que diz: "sempre que acontece uma atividade diferente, nós tentamos fotografar". Tanto nas falas das gestoras quanto nas falas das professoras é recorrente a utilização de variados termos para nomear os momentos que de fato precisam ser documentados. São atividades diferentes, destaque, interessantes, grandes, principais, especiais, importantes, muito específicas ou mais legais ${ }^{54}$. Termos estes, que, quando analisados, indicam que o registro deve estar associado aos "momentos privilegiados" na rotina da escola.

A lógica de fotografar apenas as "atividades especiais" não está explicita nos projetos pedagógicos, mas fica evidente nas falas das entrevistas e nos registros produzidos por mim na observação participativa. Iniciando pelo fato de as educadoras se preocuparem em saber quando seriam minhas visitas a cada grupo, para que pudesse haver um planejamento mais detalhado para esses momentos, que seria incluído na condição de "especial".

Conforme se iniciou a etapa de inserção nos quatro grupos, em 2019, uma cena se repetia: as crianças participando de atividades direcionadas e sentadas à mesa em pequenos grupos (Figura 27) - um cenário que destoava das propostas que vinham ocorrendo no ano anterior, mas que, de certa forma, parecia mais favorável para que as educadoras produzissem as fotografias. No primeiro mês de observação, isto se repetiu grupo a grupo: a professora iniciava um encaminhamento para que as crianças se organizassem às mesas e, durante um momento tranquilo, as fotografias eram produzidas.

\footnotetext{
${ }^{54}$ Nuvem de palavras | Dimensão de análise: "Momentos privilegiados", disponível no Apêndice E.
} 


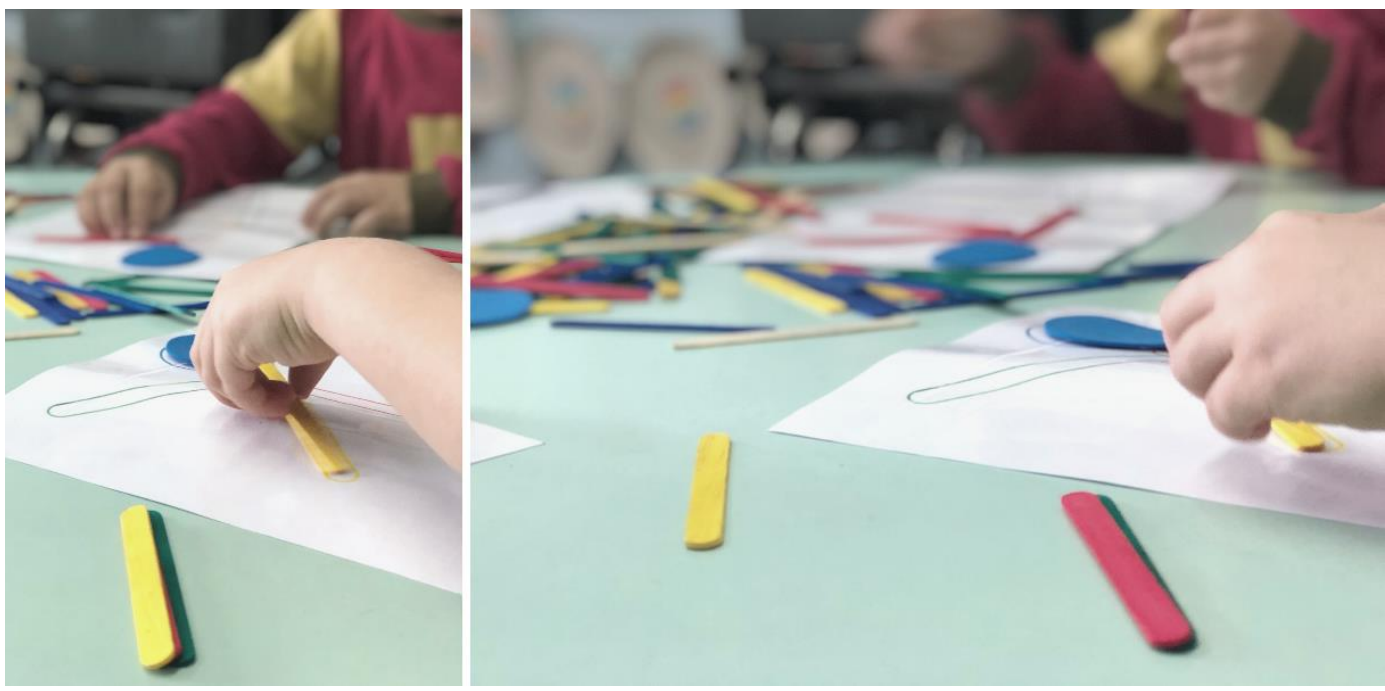

Figura 27 - Fotografando vivências dirigidas Fonte: Acervo da autora.

Alguns questionamentos vieram à tona: Por que as professoras vinham restringindo as fotografias a momentos mais controlados? As fotografias seriam feitas da mesma forma, caso a pesquisa não estivesse acontecendo? Por que este tipo de vivência vinha sendo privilegiado no currículo da escola?

Importante lembrar que desde a primeira visita à escola e com a leitura do PPP (2018), identificou-se que a equipe já vinha caminhando em direção a uma ressignificação do currículo, flexibilizando organização de tempo e espaço, com propostas pedagógicas que proporcionam mais liberdade às crianças. Isto se confirma na fala de uma educadora durante a entrevista:

\begin{abstract}
Inajara (professora/2019) - Dias atrás, trabalhamos com desenho livre em papel pardo. Enquanto as crianças desenhavam, eu tirei fotos de cima, com a criança desenhando no chão. Procuro mudar o mobiliário da sala de lugar para que as crianças possam explorar todo o ambiente. Minha sala, por exemplo, normalmente, só fica com duas mesas. Se preciso fazer uma atividade dirigida, uso as mesas e tiro novamente. O espaço fica mais amplo, para se sentar no chão, brincar... Nesse momento eu fotografo de vários ângulos.
\end{abstract}

Então, por que as educadoras estariam adotando práticas diferentes desta relatada ou dando menos liberdade às crianças enquanto produziam registros?

A hipótese levantada foi de que as professoras poderiam estar com dificuldade de organizar os momentos para fotografar dentro da proposta curricular da escola. Pensando nesta possibilidade, em um momento de partilha com elas, levantou-se uma reflexão sobre os tempos e espaços que vinham sendo privilegiados no currículo, principalmente em relação à fotografia. Assim, as educadoras foram motivadas a contar como estava sendo o processo de 
adaptação do currículo da escola à BNCC.

\begin{abstract}
Franciane (professora/2019) - Minha visão é de que a EMEI Dom João A. Hoffmann já vinha em uma caminhada, talvez um pouco lenta, mas eu diria que bem assertiva, principalmente, em relação a novas metodologias que vem sendo adotadas em outros lugares, como em Reggio Emilia. Nós já estávamos em uma caminhada em que não existiam mais conteúdos em uma sequência fixa: "corpo", "animais", etc. Já não existia uma sequência pré-definida. la se percebendo que a criança tinha interesses. E também a organização dos espaços. Não se usa mais tanta cadeira, tanta mesa. Nós procuramos deixar a criança mais livre pra explorar o espaço, objetos e materiais. Estamos tendo algumas formações proporcionadas pela SMED e a coordenadora passou a organizar alguns espaços na escola para uso coletivo, que eu entendo que se aproxima do "brincar heurístico". Isso tudo vem ao encontro da BNCC. Não houve uma mudança grande no trabalho que nós já fazíamos. Com essas pequenas mudanças, eu consegui perceber que a BNCC já estava sendo implementada. Não houve uma ruptura. Algumas professoras reclamam muito de que a BNCC é uma carga a mais de trabalho para o professor, mas nós já fazemos tudo isso, talvez de uma forma um pouco diferente ou com outro nome.
\end{abstract}

Tchéssika (professora/2019) - Nós já tínhamos desconstruído a ideia de ficar muito tempo na sala de aula. Nós brincamos muito na grama, no parque externo... as crianças já tinham essa liberdade. A BNCC também sugere a utilização de diferentes espaços da escola, contato com a natureza e a brincadeira ao ar livre. Também fomos desconstruindo a ideia da "fila". São coisas que tentamos fazer, mas que nem sempre conseguimos.

Andressa (professora/2019) - A BNCC assustou bastante todo o grupo de professoras, não só na Dom João A. Hoffmann, mas em todas as escolas. A SMED está ofertando alguns dias de formação pra discutirmos a BNCC, mas sinto que nem nesses momentos de "ordem maior" tivemos uma orientação clara. A mudança já está turbulenta a nível nacional e quando chega na escola nós não estamos conseguindo discutir como deveríamos. Aquilo de aprofundar na BNCC e entender o que ela quer dizer, que os conteúdos não são fragmentados, que não podemos mais trabalhar com "projetinhos" pontuais com uma sequência fixa, ainda não está acontecendo. Como as informações não são claras, parece difícil implementar. Isso é o que escuto de professoras de outras escolas. Mas nós, como já estávamos trabalhando dentro dessa proposta, ficamos mais calmas em relação a isso. Já escutei uma colega dizendo: "Não dá pra só ir atrás do que a criança quer! Que planejamento eu vou fazer?". Mas não é isso que a BNCC diz. Óbvio que não é qualquer palavra que a criança diz que vai se tornar uma boa atividade, mas muita gente não compreendeu que é para partir da curiosidade da criança, para desenvolver o planejamento.

As falas mostram que a adaptação do currículo à BNCC vinha gerando algumas inseguranças no grupo. Em contrapartida, as educadoras reconhecem que a escola já vinha realizando um movimento de ressignificação do currículo. Portanto, não viam a BNCC como uma ruptura em relação ao que vinha acontecendo no ano anterior.

Continuando o debate, refletimos sobre as implicações da BNCC para a prática de documentação na escola. Inicialmente, as professoras tiveram dificuldade de relacionar a proposta da BNCC com a forma com que vinham documentando as vivências e o cotidiano com as crianças na prática - "Não sei 
se tivemos alguma orientação sobre a forma de documentar". Contudo, conforme a discussão se desenvolveu, passaram a pensar na operacionalização da produção de registros.

\begin{abstract}
Tchéssika (professora/2019) - O que mudou foi em relação ao registro $e$ documentação dos conteúdos trabalhados. Antes nós registrávamos apenas as atividades realizadas, por exemplo: "atividade de desenho" ou "hora do conto". Agora, registramos o conteúdo ou as aprendizagens possíveis. Eu acho que isso também tem relação com a BNCC. (...) Com a BNCC, nós passamos a registrar as falas das crianças, não só nos pareceres avaliativos, mas em várias atividades, como complemento. Por exemplo, registrar o que a criança fala e faz antes, durante $e$ após determinada atividade. As fotos ajudam a mostrar aspectos presentes nos registros das falas das crianças. Isso tudo está sendo bem trabalhoso. Não sei se já consigo relacionar todos os registros.
\end{abstract}

A partir dessa reflexão, as professoras parecem ter percebido que vinham enfrentando dificuldade na composição da documentação como um conjunto de registros, que não se concluem em si, mas que precisam se integrar. A fotografia, nesta perspectiva, precisa dialogar com os registros das falas das crianças, com as anotações das professoras em seus anedotários e com todas as outras produções das crianças. Assim, as fotos produzidas pelas professoras nos momentos em que havia maior controle e previsibilidade das ações das crianças, pareciam estar associadas a essa dificuldade que vinham enfrentando na criação de sentido, que só é possível quando os registros se complementam, para narrar as experiências de forma processual e completa (Malavasi, Zoccatelli, 2019).

\title{
4.4.1 \\ Câmera fotográfica ou aparelho celular?
}

Desde o início do período de imersão na escola, havia o interesse de se identificar como e quando as educadoras fotografavam. Entender como cada professora fotografa, ao menos em primeira instância, perpassa pela identificação dos equipamentos para captura de imagem utilizados.

Em 2018, na observação dos espaços de uso coletivo da escola, percebeuse que as gestoras costumavam utilizar câmeras digitais compactas, mas usavam, principalmente, seus aparelhos celulares para fotografar as vivências de integração no pátio interno. Já em 2019, no acompanhamento dos quatro grupos, foi necessário avaliar a prática das quatro professoras, o que demandou mais tempo para que se chegasse a alguma conclusão sobre os equipamentos utilizados por todas. Ao longo dos dias de observação, conforme as vivências no 
âmbito dos projetos que vinham acontecendo, as professoras, em atuação com seus grupos, costumavam incluir um momento para fotografar na minha presença. Com isso, ficou mais fácil acompanhar os momentos em que cada uma fotografava as crianças.

Na metade da tarde, quando cheguei à sala do Grupo Amarelo, as crianças estavam em círculo, formado com cadeiras, cantando uma música coreografada, com gestos conduzidos pela professora. Atravessei a sala, em direção à mesa da professora, guardei minha mochila e peguei uma cadeira para me juntar às crianças, como de costume. Percebi que me esperavam, que minha chegada já estava anunciada pela professora e que o grupo estava um momento transitório, se preparando para iniciar outra atividade. Conforme me acomodo no círculo, a professora inicia as orientações para as crianças brincarem com um jogo em madeira, com peças não estruturadas. As crianças iniciaram uma organização espontânea, em pequenos grupos. Enquanto alguns meninos se sentaram ao chão, um grupo de meninas continuou conversando entre si, ainda de pé, sem pegar o jogo. Nesse momento, vejo que a professora já está com a câmera fotográfica na mão. Obs.: Percebi que a Fran sempre usa a câmera da escola - uma câmera digital compacta, bem "antiguinha", que demora alguns segundos para exibir a foto no visor após o disparo (Nota de campo da pesquisadora, junho/2019). (Figura 28)
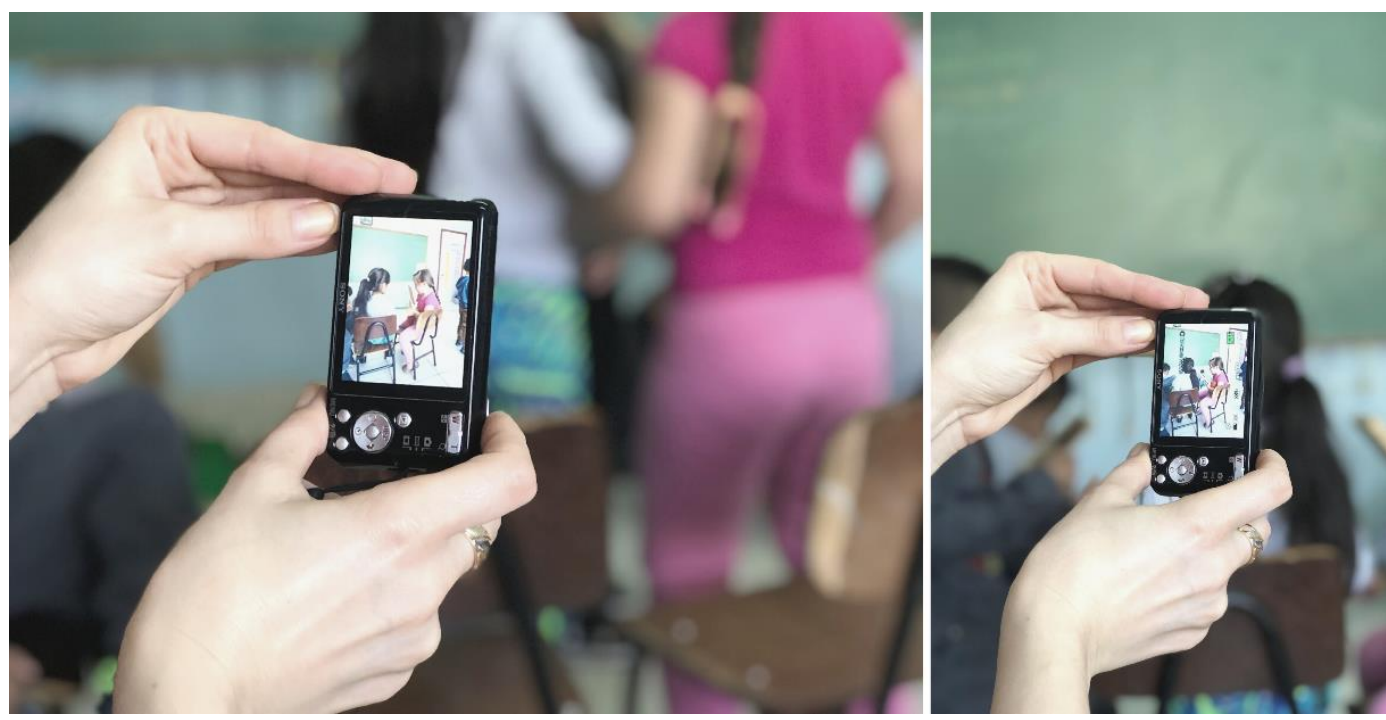

Figura 28 - Fotografando com câmera fotográfica digital Fonte: Acervo da autora.

As salas dos quatro grupos eram equipadas com uma câmera digital compacta (identificada com selo patrimonial do município), que ficava guardada no armário do professor. Não eram câmeras de última geração. Algumas tinham marcas e arranhões, que discriminavam seu tempo de uso. Essas câmeras também haviam sido utilizadas pelas crianças, em 2018, quando fotografaram os espaços da escola para o projeto que marcava o centenário de Erechim e o aniversário da escola. Em algumas ocasiões, enquanto as educadoras fotografavam as crianças, a câmera acusava nível baixo de bateria, fazendo-as 
interromper a sessão para carregar o equipamento. Ou então, quando eu chegava à sala para observação, a bateria já estava sendo carregada, para que a câmera pudesse ser usada na vivência seguinte.

Chamou atenção o fato de as professoras utilizarem as câmeras da escola para registrar os momentos pedagógicos, considerando a baixa qualidade das imagens produzidas, em comparação com os aparelhos celulares que as próprias professoras, possivelmente, tivessem. Isso foi indagado às professoras, e a justificativa, segundo elas, era de que "usar o celular em sala de aula não é uma atitude profissional, pode não 'pegar bem". Percebeu-se, então, que as professoras tinham consciência de que as câmeras da escola não eram a melhor opção para produção de imagens de alta qualidade, mas, ainda assim, utilizá-las transmitia uma postura mais profissional do que o uso do celular.

O fato de as educadoras assumirem que para elas o uso do celular no ambiente de trabalho poderia representar pouco profissionalismo ou seriedade, incidiu na minha figura, como pesquisadora, já que desde o início da pesquisa eu vinha utilizando meu celular para registrar o percurso de observação.

Franciane (professora/2019) - No começo da pesquisa achei um pouco estranho você usar o celular pra tirar foto. Pensei que você fosse chegar com uma daquelas câmeras profissionais "poderosas".

Conforme relatado no panorama de contextualização da observação (item 3.3), existia entre as educadoras uma expectativa de que a pesquisa pudesse contribuir para que elas tivessem aprimoramentos técnicos para a fotografia. Isto apareceu constantemente na fala delas, durante as entrevistas e se refletiu em falas registradas durante a observação participativa.

Inajara (professora/2019) - Talvez você possa nos dar mais dicas, de posição, de luz... porque, mesmo que a gente tenha um programa no notebook, que dá pra editar foto, ainda daria pra melhorar a luz, essas coisas ...

O fato de não utilizar um equipamento avançado para captura de imagens, nem oferecer à equipe uma formação técnica sobre fotografia, pode ter gerado certa frustração por parte das educadoras, em etapa inicial da pesquisa. Contudo, com o passar dos meses de imersão na escola, a equipe parece ter assimilado a ideia de que seria necessária uma construção, muitas vezes subjetiva, de alfabetização do olhar (e não apenas técnica), para que se desenvolvessem habilidades necessárias para a produção de fotos de qualidade. 


\subsection{2 \\ Documentações contextualizadas ou temáticas?}

Conforme discutido no item anterior, a avaliação dos equipamentos utilizados para fotografar, aponta para um fato curioso: em 2018, presenciaramse vários momentos em que as fotografias eram feitas com celular; já em 2019, as professoras preferiam utilizar as câmeras fotográficas digitais, que pertenciam à escola, para registrarem vivências de seus grupos. É de fato curioso, pois três das quatro educadoras participaram diretamente da pesquisa desde o início - o que indica que essas três profissionais tinham modificado a forma de fotografar sua prática de um ano para outro, ao mudarem de função na escola. Quando estavam na posição de gestoras, em 2018, era comum que utilizassem seus celulares para fotografar vivências de integração relacionadas aos projetos temáticos. E, quando assumiram os grupos de Pré-A, em 2019, disseram que usar as câmeras da escola soava mais profissional.

A partir da identificação da mudança na escolha dos equipamentos utilizados para fotografar, passou-se a analisar os tipos de documentação produzidos pelas educadoras, de acordo com a função que exerciam na escola. Será que a documentação produzida pela gestão é diferente da documentação que produzem as professoras? Enquanto fotógrafas, as educadoras modificam sua postura, dependendo da função que ocupam? Que ângulos buscam em cada sessão? Em que focam quando estão na posição de gestoras? Isso mudou quando voltaram à sala de aula?

Para responder a essas perguntas, foi necessário retornar aos dados produzidos em 2018, durante a observação dos espaços de uso coletivo da escola. Retomando os momentos em que se observaram as gestoras, registrando as vivências de integração no pátio interno, percebe-se que o foco das fotografias estava no coletivo. Em entrevista, naquele ano, a coordenadora comenta que, após a realização dessas propostas, as fotos e vídeos eram transferidos para o computador da secretaria e que, a partir de uma seleção cuidadosa, produzia-se um álbum da escola, "um álbum do ano, onde ficam registradas as grandes atividades da escola". Nesse sentido, as fotos que têm como destino o álbum da escola, cumprem uma função de construção de memória da escola, formada na integração das histórias individuais das crianças e das educadoras, que ajudam a construir uma história coletiva.

Esta tipologia de registro, que não tem por foco um único sujeito, mas que é 
capaz de contar a história de um grupo, pode ser chamada de documentação temática. É possível fotografar o grupo em diferentes perspectivas, com foco em detalhes ou cenários mais amplos, para compor uma narrativa completa da experiência (Malavasi; Zoccatelli, 2019).

Em 2019, quando as educadoras assumiram os grupos de Pré-A, o que parece influenciar mais nas fotografias tiradas pelas professoras é o destino que elas teriam ou para quem elas seriam comunicadas. Nas fotos tiradas para serem compartilhadas com as famílias, por exemplo, havia intenção de mostrar com detalhe todas as etapas e processos das experimentações das crianças. Para documentar esses processos, as professoras fotografavam diferentes momentos de uma mesma vivência e selecionavam uma sequência.

As fotos em sequência costumavam ser produzidas pelas professoras em momentos em que a vivência seguia certa previsibilidade, quando as crianças estavam envolvidas em situações em que suas ações podiam ser mais facilmente identificadas. Com a câmera em mãos, as professoras tentavam identificar uma sucessão de acontecimentos para construir a noção de continuidade. Na análise de conteúdo, essas fotos foram categorizadas na dimensão de "processos de aprendizagem".

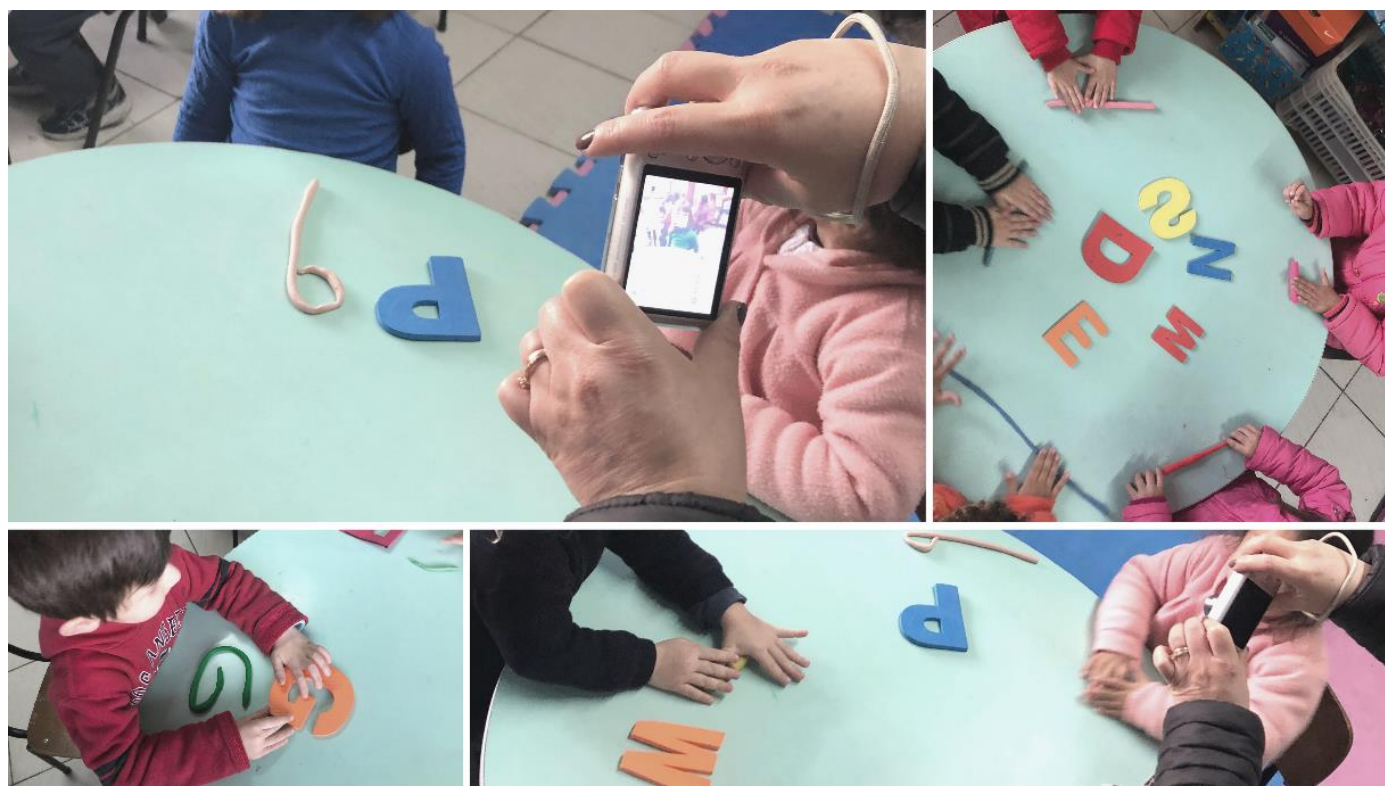

Figura 29 - Documentando movimentos em sequência Fonte: Acervo da autora.

A ideia de processo parece estar relacionada à criação de sentido possibilitada pela noção de continuidade temporal. Malavasi \& Zoccatelli (2019) consideram que as releituras das experiências podem ser de diferentes tipos, 
sendo as de caráter cronológico capazes de reconstituir diferentes fases de um mesmo percurso. São as chamadas documentações contextualizadas, que tem o objetivo de contar uma história em particular e precisam ser apresentadas dentro de um contexto que represente um fragmento da vida dos protagonistas em questão. Desta forma, "organizando uma sequência de fotografias é possível não só relatar de uma certa maneira, mas também interromper uma narração para torná-la, por exemplo, mais eficaz, criando momentos de pausa no relato" (p. 63).

Outro aspecto observado na captura dessas imagens em sequência, foi a posição corporal das professoras em relação às crianças. Na Figura 29, é possível ver, pelas mãos que aparecem segurando a câmera, que quem fotografa se posiciona acima da mesa das crianças, com a lente direcionada para baixo. As professoras tinham por hábito fotografar de cima para baixo, se colocando, geralmente, acima das crianças. Esta postura do adulto, que para fotografar se posiciona a uma altura superior à das crianças,

marca necessariamente uma distância na relação, tanto física quanto emocional. Fotografar à altura da criança é uma forma de entrar em contato com o ponto de vista das crianças relativamente ao mundo (Malavasi; Zoccatelli, 2019, p. 68).

As autoras destacam que, para evitar esses distanciamentos, a fotografia precisa ser fruto de escolha ponderada e intencional.

O hábito de fotografar as crianças de cima para baixo também traduz uma preocupação comum entre as professoras, de conseguirem incluir todas as crianças na mesma foto e evitarem exclusões ${ }^{55}$. Ao se distanciarem, posicionando-se acima das crianças ou em um canto da sala, seria possível agrupar as crianças, englobando-as na mesma imagem, conforme exemplifica o depoimento em entrevista:

\begin{abstract}
Andressa (professora/2019) - Eu acho que isso começou quando eu estava na direção. Eu sempre orientava as professoras a fotografarem o todo, todas as crianças ao mesmo tempo. Nós tínhamos o cuidado de que as fotos fossem mais no coletivo, pra que todas as crianças aparecessem, porque os pais querem ver a foto e logo encontrar o filho. Então, tínhamos que tentar não focar em uma ou outra criança. O ideal é que todo mundo apareça. Tanto é, que se você for olhar na página da escola (no Facebook), as fotos são muito mais no coletivo do que individuais. Mas esse padrão está mudando, na coletânea das crianças já dá pra notar. Por exemplo, antes tinha uma foto de todas as crianças brincando com tinta. Agora tem uma foto só do pé com a tinta.
\end{abstract}

${ }^{55} \mathrm{Ou}$ até, uma tentativa das educadoras de preservar a identidade das crianças, não exibindo seus rostos. 
A educadora, na fala acima, parece refletir sobre sua atuação na posição de gestora e professora, estabelecendo um paralelo sobre as mudanças em sua forma de fotografar. Ela diz que, quando estava na gestão, achava importante a foto contemplar o grupo todo, e era essa a orientação que se dava às professoras para as fotos que seriam divulgadas pelas redes sociais da escola. Entretanto, observa que esse padrão estava mudando em sua prática, usando como exemplo uma proposta com tinta, que antes seria documentada no coletivo e agora ela focava em aspectos específicos da criança. Segundo ela, ao invés de fotografarem todas as crianças brincando ao mesmo tempo, o foco de suas fotos estava se deslocando para os detalhes.

É interessante nesta fala da educadora a ideia de "partes" e do "todo". $\mathrm{Na}$ análise de conteúdo, este aspecto foi discutido a partir do eixo temático "local e global", aparecendo principalmente nas falas das três educadoras que faziam parte da gestão e que no segundo ano da pesquisa retornaram à sala de aula. Essas educadoras, por diversas vezes, comentavam que se antes, quando estavam na posição de gestoras, precisavam ter uma visão geral da escola, do todo, em 2019 passaram a prestar mais atenção em seu grupo, observando mais as individualidades das crianças, e parecem ter percebido que isso se refletia no ato de fotografar.

A discussão sobre as nuances da documentação em âmbito local e global foi retomada junto às educadoras durante os diálogos de reuniões pedagógicas. O grupo ponderou a importância de se produzir documentação tanto em nível local quanto global. Constituiu-se, assim, uma delimitação conceitual destas dimensões, estabelecendo um paralelo com os tipos de documentação contextualizadas e temáticas - a partir dos contornos de delineação da fotografia no percurso individual e coletivo das educadoras ao longo da pesquisa. 
Dimensões da documentação com apoio da fotografia

\begin{tabular}{|c|c|c|c|}
\hline Dime & ensão & Definição conceitual & Instrumentos de comunicação \\
\hline 『్ర & 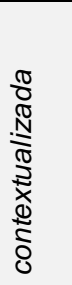 & $\begin{array}{l}\text { Produto documental fotográfico que narra os } \\
\text { percursos de aprendizagem e vivências da criança na } \\
\text { escola. Apoia a avaliação que as professoras fazem } \\
\text { de cada criança, comunicado-a às famílias. }\end{array}$ & $\begin{array}{l}\text { - Coletânea/Portfólio da criança } \\
\text { - Redes sociais } \\
\text { - Exposições de fotografia } \\
\text { - Painéis e murais da escola }\end{array}$ \\
\hline $\begin{array}{l}\bar{\pi} \\
\frac{0}{0} \\
\frac{0}{0}\end{array}$ & 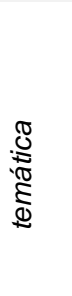 & $\begin{array}{l}\text { Produto documental fotográfico coletivo, que narra } \\
\text { processos da escola como um todo. Apoia a } \\
\text { avaliação do trabalho que é desenvolvido pelas } \\
\text { escolas, pondo-as em diálogo com suas redes e } \\
\text { sistemas de ensino. }\end{array}$ & $\begin{array}{l}\text { - Álbum de fotos da secretaria } \\
\text { - Reuniões promovidas pela } \\
\text { SMED } \\
\text { - Redes sociais } \\
\text { - Exposições de fotografia } \\
\text { - Painéis e murais da escola }\end{array}$ \\
\hline
\end{tabular}

Quadro 13 - Dimensões da documentação com apoio da fotografia Fonte: Elaborado pela autora.

O debate gerado nas reuniões pedagógicas indicou que a concepção das educadoras sobre as demandas de seu trabalho a nível local e global incidia diretamente sobre os tipos de documentação com fotografia produzidos por elas. Assim, os conceitos de local e global foram compreendidos a partir da definição de documentações contextualizadas e documentações temáticas, respectivamente (Malavasi; Zoccatelli, 2019).

Conforme apresenta o Quadro 13, a nível local, produz-se documentação contextualizada, pelas quais as professoras buscam tornar visíveis os processos de aprendizagem de cada criança, individualmente. Esse tipo de documentação com fotografia torna possível avaliar o desenvolvimento das crianças quanto a habilidades específicas, a partir da interpretação e significados dados por elas às fotos. Em âmbito local e situado, a documentação depende exclusivamente dos registros fotográficos que são feitos pelas professoras. Este tipo de documentação permite que o desenvolvimento das crianças seja avaliado, a partir de seu percurso e vivências, interpretados nas fotografias. Para as professoras, a documentação a nível local contribui para o aprimoramento de sua prática e de ações pedagógicas no cotidiano do contexto educativo, envolvendo aspectos do currículo, planejamento, observação, intencionalidade e avaliação das crianças (Figura 30). 

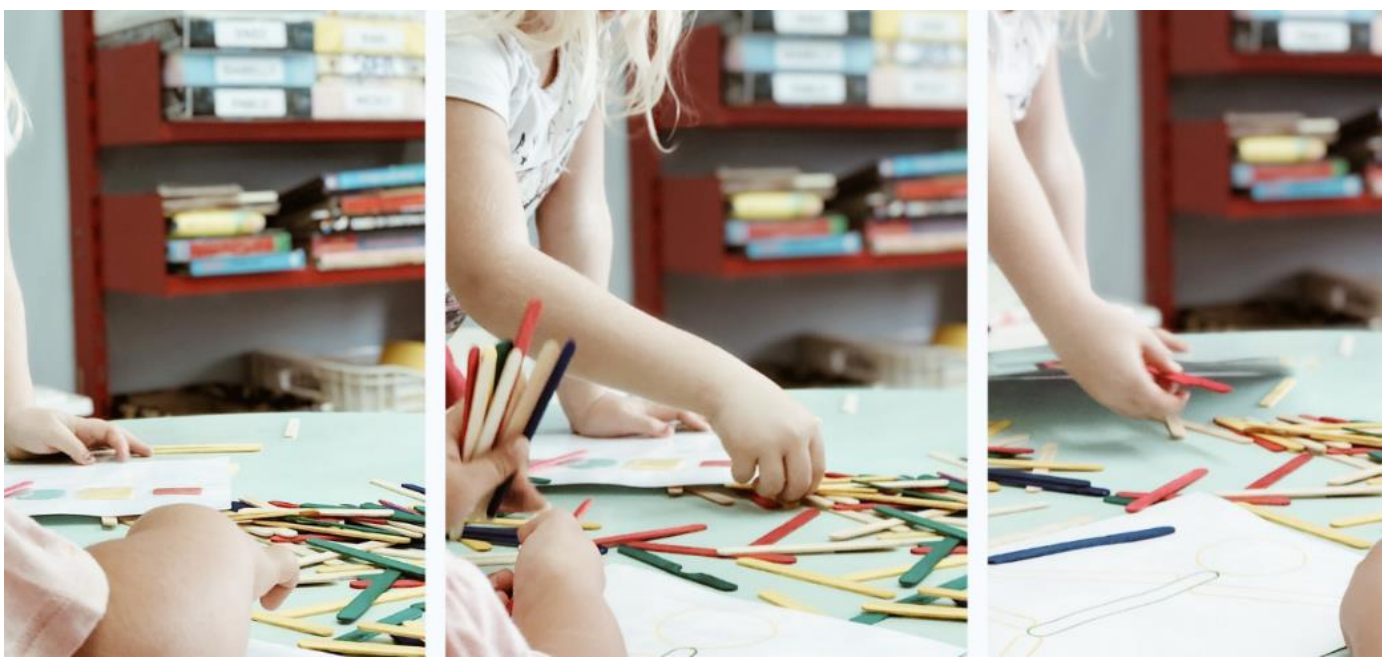

Figura 30 - Documentação contextualizada Fonte: Acervo da autora.

Já as fotografias produzidas no âmbito das documentações temáticas eram geralmente produzidas pela equipe de gestão e narram os processos coletivos vividos em cada contexto, para os sistemas de ensino e para a comunidade, de forma mais abrangente. Este tipo de documentação pode contribuir com a avaliação das instituições, alcançando políticas que incidem na melhoria da qualidade da educação infantil. Além dos instrumentos de comunicação que a escola já produz a nível local, estas documentações também são compartilhadas com educadores de outras escolas e com instâncias administrativas da rede de ensino, em reuniões organizadas pela SMED. As educadoras citam, em entrevista, que este tipo de documentação é comunicado à rede municipal de ensino nos encontros de coordenadores pedagógicos, que costumam acontecer ao final de cada ano, e nas reuniões semestrais dos professores de AEE.

\section{5}

\section{0 que se pretende comunicar com as fotografias?}

A pesquisa indica que na escola a documentação cumpre uma função comunicativa, na qual a família possui centralidade. Em 2019, as professoras dizem fotografar com o intuito de elaborar seu planejamento e avaliá-lo junto às colegas e outros agentes educativos. Contudo, percebemos que existe uma preocupação maior em relação à documentação destinada aos pais e familiares das crianças, uma espécie de elo entre o mundo da escola infantil e o mundo externo, que comprova e valida o trabalho docente. 
Mas, voltando ao questionamento, o que se pretende comunicar com as fotografias? É interessante que a resposta a essa pergunta pareça estar deslocada no diálogo estabelecido nas entrevistas e, talvez, esteja subentendida em resposta a outra questão. Quando perguntei às professoras: "Em que você pensa enquanto fotografa?", a resposta indica uma relação direta com a família da criança. Inajara (professora/2019) - Penso em que eu gostaria de ver enquanto mãe. Eu
teria curiosidade de abrir a coletânea e ver o que aconteceu durante aquele ano
com o meu filho, como ele se comportou, em que ele evoluiu.

Tchéssika (professora/2018) - Então, quando eu fotografo fico sempre pensando na família. Em casa, mãe e o pai vão se sentar, vão abrir a coletânea e vão sentir prazer em ver aquilo que o filho fez.

Quando a educadora diz que pensa "enquanto mãe", traz consigo um dado relevante: o exercício das educadoras de imaginarem o julgamento das famílias quando visualizam os registros produzidos pela escola. Três das quatro educadoras participantes, apontam que a escola precisa mostrar o bem-estar da criança, através do que é documentado.

Andressa (professora/2019) - Nós gostamos de fotografar momentos em que as crianças estão felizes, experimentando algo diferente, aprendendo coisas novas.

Falas como esta, sugerem que, na documentação, a escola comunica se a criança está realmente adaptada ao ambiente educativo, se participa das vivências e se interage bem com outras crianças. Na análise de conteúdo, este dado foi categorizado na dimensão do "cuidado". Os depoimentos coletados em entrevista permitem inferir aspectos do pensamento das educadoras quando estas estão no papel de fotógrafas, e captar detalhes da subjetividade deste gesto. Embora haja um planejamento do que deve ser fotografado ao longo dos projetos, que é realizado com antecedência, os recortes e escolhas feitos com a câmera em mãos envolvem outras questões, de âmbito pessoal e subjetivo, mas também cultural e social. Cada educadora relata ter um pensamento específico enquanto fotografa, porém, entre todas, há uma preocupação comum a respeito da maneira que os pais verão os filhos nas fotografias que são produzidas.

Com esse mesmo dado, provoca-se uma problematização no campo dos estudos de gênero (Scott, 1995; 1998; 2007; Louro, 1997). Quando a professora diz que tenta pensar como mãe, coloca-se em um papel que é comumente 
associado ao profissional da educação infantil: a maternidade.

No contexto histórico brasileiro, as escolas de educação infantil e creches têm se consolidado como um espaço predominantemente feminino. Quando a proposta pedagógica com crianças pequenas é associada à maternidade, aproxima-se a escola e o trabalho educativo feminino a certos estereótipos de gênero. Isto porque, tradicionalmente, mulheres têm a responsabilidade de cuidar de crianças para que outras mulheres possam trabalhar formalmente fora de casa. Assim, a escola, apesar de sua crescente relevância social, não possui exclusividade como agência educativa das crianças e precisa dividir esse papel com a família (Gomes, 1994).

Ao analisar historicamente os processos de socialização da criança a partir de seu nascimento, Gomes (1994, p. 57) pontua que

\begin{abstract}
a família atual brasileira deriva, na verdade, das transformações dos modelos anteriores, sob a ação, dentre vários fatores, da urbanização, das migrações externas e internas, da formação do proletariado, do desenvolvimento da mídia e das modernas condições femininas de vida e de trabalho. [...] Escusado dizer, neste quadro, que ainda cabe à mulher - apesar de seu engajamento crescente no mercado de trabalho formal - a responsabilidade maior na ação socializadora.
\end{abstract}

No contexto da pesquisa, temos em falas das educadoras indícios desse compartilhamento de responsabilidades ${ }^{56}$, que se cumpre com a composição e divulgação da documentação. Quando as educadoras fazem o exercício de fotografar tentando se colocar no lugar de mãe expectadora, em alguma medida, elas estão se solidarizando com as mães trabalhadoras, e transferem para elas mesmas a responsabilidade pelo cuidado e zelo do bem-estar das crianças.

Retomamos o referencial teórico da pesquisa, trazendo novamente as contribuições da abordagem pedagógica de Reggio Emilia para a discussão sobre a função comunicativa da documentação pedagógica na relação família-escola. Por volta de 1990, Loris Malaguzzi refletiu sobre a importância da divulgação da documentação aos familiares das crianças:

Tornar visível, por meio da documentação, o prazer de aprender e a complexidade das ações e invenções das crianças é uma maneira de incluir os familiares e ajudálos a entender a potência das crianças. Isso é essencial não apenas no que diz respeito aos próprios filhos, mas também para encorajá-los a apoiarem as experiências de todas as crianças da escola (Gambetti; Gandini, 2020, p. xii57).

\footnotetext{
56 Este compartilhamento de responsabilidades também se ampara no artigo 205 da Constituição Federal (1998).

57 Gambetti e Gandini, 2020 - paginação em formato E-pub/Kindle.
} 
A série O Começo da Vida (2016) aborda a reflexão de que as crianças não podem ser responsabilidade exclusiva das mães, mas da sociedade como um todo, com uma cultura que se organize de forma comunitária. Há, em um dos episódios da série, uma referência a Reggio Emilia, já que a cidade manifesta há muito tempo uma "vocação pedagógica". Neste episódio, a atelierista italiana Vea Vechi diz que "é a cidade, a comunidade que deve acolher as crianças". A cidade precisa organizar a vida para conseguir atender de forma adequada as crianças. Isto também aparece no depoimento de uma mãe na série, que destaca que "as escolas de Reggio Emilia não se limitam a cuidar das crianças", mas além de cuidar, a escola está fundamentada em três elementos compostos por Loris Malaguzzi: as crianças, os professores e os pais. $E$ os três possuem responsabilidades iguais na educação das crianças. Nesta mesma perspectiva, Claudia Giudici, presidente da Reggio Children, pontua que:

\begin{abstract}
Nesse processo, o importante é que os pais não são pais só do próprio filho, mas também se tornam pais que conseguem cuidar, se ocupar e se interessar pelas outras crianças, pela classe em que o filho estuda, pela escola e pela cidade. É um processo de crescimento civil, cultural e social. Costumamos definir as creches e jardins de infância como laboratório de emancipação cultural e democrática. E são processos importantes não só para aquelas pessoas, mas é um capital social que retorna para toda a comunidade (tradução livre, O Começo Da Vida, 2016).
\end{abstract}

Nesta reflexão, a documentação pedagógica é percebida como um instrumento que torna possível um acesso mais qualificado das famílias aos momentos de aprendizagem das crianças.

\title{
4.5.1 \\ Portfólio da criança
}

No escopo documental produzido com intuito de ser compartilhado com as famílias, apresentou-se com maior relevância o portfólio individual das crianças. As escolas da rede municipal de ensino de Erechim não recebem uma orientação padrão para a produção de documentação das aprendizagens e desenvolvimento da criança, mas as quatro educadoras participantes da pesquisa são unânimes em afirmar que a prática mais comum entre as escolas de educação infantil é a produção de portfólios individuais. A investigação em relação a estes artefatos se deu no sentido de compreender quais eram os processos para sua produção, como se atribuía sentido à documentação desses portfólios e qual o lugar da 
fotografia em sua composição. Antes disso, porém, foi necessário retomar sua definição conceitual, uma vez que as educadoras se referiam a "portfólio" e "coletânea" como sinônimos, alternando a utilização dos termos para nomear o mesmo artefato. Percebeu-se, assim, que podia haver uma confusão conceitual em relação a utilização destes termos:

\begin{abstract}
Andressa (professora/2019) - A "coletânea" de atividades é anual. Então, ao longo do ano, tudo aquilo que a criança produz e se registra em papel vai sendo arquivado, guardado e depois se transforma no "portfólio". As produções das crianças também são registradas com fotografia. (...) As fotos se tornam documentação pedagógica quando vão para o "portfólio", ou melhor, para a "coletânea" de atividades, porque não é um "portfólio", é uma "coletânea", com as atividades que foram sendo desenvolvidas ao longo do ano.
\end{abstract}

Assim, recuperou-se a revisão teórica da tese, em busca do referencial sobre documentação pedagógica na educação infantil e estudos sobre os processos de produção do portfólio da criança (Oliveira-Formosinho, 2002; Parente, 2002; 2004; Azevedo, 2009). As autoras inscrevem a realização de portfólios como uma estratégia de avaliação na perspectiva da avaliação alternativa, em que a criança tem uma atitude menos passiva, passando a desempenhar um papel ativo nas propostas de avaliação.

Parente (2004) avaliou a qualidade dos portfólios de professoras portuguesas em relação aos processos de construção, constatando que quando há um planejamento mais cuidadoso e maior reflexão prévia, estes artefatos "são melhor sucedidos ao nível da variedade de conteúdos e de representação" ( $p$. 329) do que aqueles construídos a partir de processos mais empíricos e tateados. Outros indicadores de qualidade do portfólio podem ser:

- processos de realização mais ponderados, refletindo na estrutura de portfólios que se organizam em categorias;

- processos em que há ação cooperada entre educadoras e, posteriormente, isomórficos com as crianças e as famílias, pois os portfólios costumam ser mais variados e diversificados ao nível dos conteúdos e dos procedimentos de registro destes.

Em contrapartida, a autora pontua que os processos de realização menos partilhados e mais centrados nas educadoras podem ser mais restritos e, portanto, menos qualificados. Parente (2004) também destaca que os processos de construção dos portfólios podem suscitar a atenção para outras dimensões curriculares de qualidade da educação infantil. Chama atenção para a necessidade de que educadores compreendam a existência de uma estreita 
ligação entre suas ações pedagógicas/ curriculares e as estratégias de avaliação, para que seja possível construir dados e informações que serão incluídos nos portfólios das crianças.

Para avaliar o lugar da fotografia na construção dos portfólios nos quatro grupos, estabeleceram três principais aspectos:

- Seleção das fotografias - processo de seleção e descarte das fotografias para inclusão destas nos portfólios das crianças.

- Organização do portfólio - design construído para inclusão das fotografias nos portfólios, estrutura de organização e distribuição das imagens em relação a outros registros das crianças.

- Interpretação das imagens - percurso de leitura e interpretação das fotografias incluídas nos portfólios.

Perguntou-se em entrevista às educadoras como é feita a seleção e o descarte de fotos para construção do portfólio das crianças. Nas respostas, as professoras dizem que adotam como critério, primeiro, a identificação das fotos que podem ser descartadas. Entre os critérios levados em conta para eliminar algumas fotos, destacam-se:

- Qualidade técnica - fotos desfocadas ou aquelas em que não se consegue distinguir pessoas e materiais.

- Correspondência entre foto-realidade ${ }^{58}$ - fotos que não representam com fidelidade as vivências das crianças.

- Exposição inadequada da criança - fotos que mostram as crianças em posições ou gestos inadequados, podendo thes causar algum constrangimento.

- Exposição inadequada dos adultos - fotos que mostram outros profissionais da escola ou as próprias professoras em posições ou gestos inadequados, podendo lhes causar algum constrangimento.

- Estética do ambiente - fotos em que o espaço aparece "bagunçado" ou quando o entorno tira a centralidade dos processos a que se pretende dar visibilidade.

As falas registradas a seguir são exemplares do processo de inclusão e descarte das fotos ao portfólio das crianças:

\footnotetext{
58 Referenciado em: Sontag, 2004; Ibañez, 1986; Barthes, 1984.
} 
Franciane (professora/2019) - Eu seleciono a foto que mostra o que eu tinha intenção de registrar: o movimento da criança ou o material que está sendo explorado... Também seleciono as fotos tomando cuidado com o entorno da criança, observando se o ambiente aparece organizado e como as outras crianças estão posicionadas, se o conjunto contribui pra estética da foto. $E$ as fotos que eu descarto são as que a criança está "estranha" - com o olho entreaberto, por exemplo - ou com partes do corpo a mostra, de forma inadequada. Também descarto as fotos que ficam "borradas", quando não se consegue ver direito o que estava acontecendo no momento ou que não dá pra entender o movimento que estava sendo executado pela criança. (...) Pra mim, o que facilita a seleção de fotos é que, normalmente, eu demoro uns dois/três dias pra fazer o registro de uma mesma atividade, então um grupo é fotografado em um dia, outro no outro... assim, tenho mais tempo pra fazer a foto e a criança tem mais tempo de vivenciar a atividade proposta. Essa tranquilidade na hora de fazer os registros contribui pra que a qualidade da foto fique melhor e pra que eu não precise descartar tantas fotos, é mais fácil fazer a seleção. (...) Eu acrescentaria outro ponto: eu, enquanto fotógrafa, me posiciono em frente à criança, outras vezes acima, outras ao lado, sempre buscando o melhor ângulo. Então, se em algum momento, a foto que eu fiz em frente à criança não mostrou o que eu tinha a intenção de mostrar, eu tenho a foto que fiz de cima ou ao lado. Essas várias posições do nosso corpo em relação à criança facilitam pra que eu faça várias fotos, dando mais opção na hora de selecionar.

Inajara (professora/2019) - Só descarto a foto que não fica muito boa ou que fica desfocada. Também descarto a foto em que a criança fica em uma situação que talvez a família não compreenda o momento exato da atividade. Se eu percebo que tem um grupo de crianças brincando e, por motivo $A$ ou $B$, está acontecendo algum problema de interação e tem uma criança isolada - minha turma da manhã tem bastante problema de socialização - e eu tirar uma foto, então eu não utilizo. Isso pode dar outro entendimento pra foto. Por mais que não seja um entendimento verdadeiro, quem olhar pra foto vai perguntar o que aquela criança está fazendo isolada ali.

Após a produção de registros, é necessário um trabalho de organização dos mesmos para que seja possível compartilhá-los, discuti-los e interpretá-los (Gandini; Goldhaber, 2002). Contudo, é curioso que, quando relatam como é feita a organização dos portfólios, as professoras direcionam sua fala para um aspecto mais instrumental deste processo, explicando somente como é feita a impressão das imagens, conforme o exemplo das falas a seguir:

Andressa (professora/2019) - Depois de selecionar as fotos, eu escolho a opção de impressão. Assim, tem a opção de imprimir quatro fotos por folha, nove por folha... Então, eu preciso contabilizar pra encaixar o número certo de cópias disponíveis pra impressão em tinta colorida. (...) Nós temos uma cota para impressões coloridas e também em preto e branco, mas como nós fazemos muitas cópias coloridas para imprimir as fotografias, muitas vezes acabamos ficando sem cota no mês. Quando a cota acaba, nós acabamos imprimindo as fotos em preto e branco, o que eu não acho muito bom, porque a qualidade da impressão em preto e branco não é boa, fica desfocada, não tem a mesma nitidez que a impressão colorida. Mesmo assim, recorremos a essa opção pra não perder os registros em fotografia feitos naquele mês. 
Tchéssika (professora/2019) - Nós imprimimos as fotos de acordo com a quantidade de cópias disponíveis, dependendo da quantidade de páginas de impressão colorida que cada professora tem.

As professoras parecem desconsiderar que o design de organização das fotos impressas nos portfólios também é uma construção estética relevante. Nesse sentido, a avaliação dessa etapa foi feita com base em materiais empíricos produzidos na observação participante.

Percebeu-se que as quatro professoras costumavam incluir os registros nos portfólios de maneira semelhante, sendo o formato mais recorrente, a composição com imagem e texto. Com a preocupação de que as imagens sozinhas possam não fazer tanto sentido ao leitor do portfólio que não participou da experiência real, as educadoras elaboram uma combinação de registros, de diferentes tipologias, para compor as documentações das crianças. Uma composição muito utilizada costuma ser a junção de registros fotográficos com textos escritos ou com uma produção artística da criança. Pensando que é possível ampliar as possibilidades interpretativas deste tipo de composição de registros, Malavasi \& Zoccatelli (2019, p. 53) destacam que

\begin{abstract}
um texto pode tentar narrar as imagens de modos diferentes: pode ser didascálico e explicar exatamente o que acontece naquela imagem, mas pode ser ainda mais eficaz associando a uma fotografia uma seleção de palavras de 'sabor' evocativo, aparentemente não relacionadas diretamente com a imagem. Quando tal acontece, os dois elementos - palavras e imagens - ressoam de modo amplificado, potencializam-se reciprocamente e tornam assim mais forte a mensagem.
\end{abstract}

Houve uma ocasião na escola em que foi possível acompanhar diferentes etapas da organização do portfólio em um dos grupos, com uma proposta que explorava a linguagem fotográfica em diferentes dimensões. Nesta experiência, a professora planejou uma vivência utilizando as fotos das crianças como apoio para a elaboração de outros tipos de registro, conforme narrado a seguir.

Na manhã de hoje, quando cheguei à sala do Grupo Rosa, as crianças estavam sentadas no chão, em círculo. A Tchéssika também fazia parte do círculo, sentada em uma cadeira junto das crianças, conduzindo um diálogo sobre a importância do debate em roda, de todos poderem falar, de verem e ouvirem uns aos outros. Uma das crianças me chamou para compor o círculo. Sentei-me no chão, ouvi a conversa e tomei nota, sem fazer comentários. Em seguida, depois de conduzir as crianças ao refeitório para o lanche, a professora me chamou de volta à sala, pois queria mostrar uma atividade que o grupo havia feito a partir de um registro fotográfico da roda de conversa (Nota de campo da pesquisadora, junho/2019). 
Conforme demonstra a Figura 31, para documentar o momento de roda de conversa - estratégia pedagógica que costuma fazer parte da rotina de escolas de educação infantil - a professora fotografou as crianças sentadas em círculo ao chão. Depois de imprimir a fotografia e colá-la em uma folha A4 em branco, as crianças foram convidadas a representarem a roda de conversa com desenhos. Nesse caso, além da fotografia impressa ajudar a contar a história de um processo vivenciado pelas crianças, ela serviu de apoio visual para a elaboração dos desenhos. A composição recebeu ainda um texto escrito, que cumpria função de legenda explicativa: "a roda é um lugar de encontro, sua circularidade possibilita à criança ver e ouvir o outro".

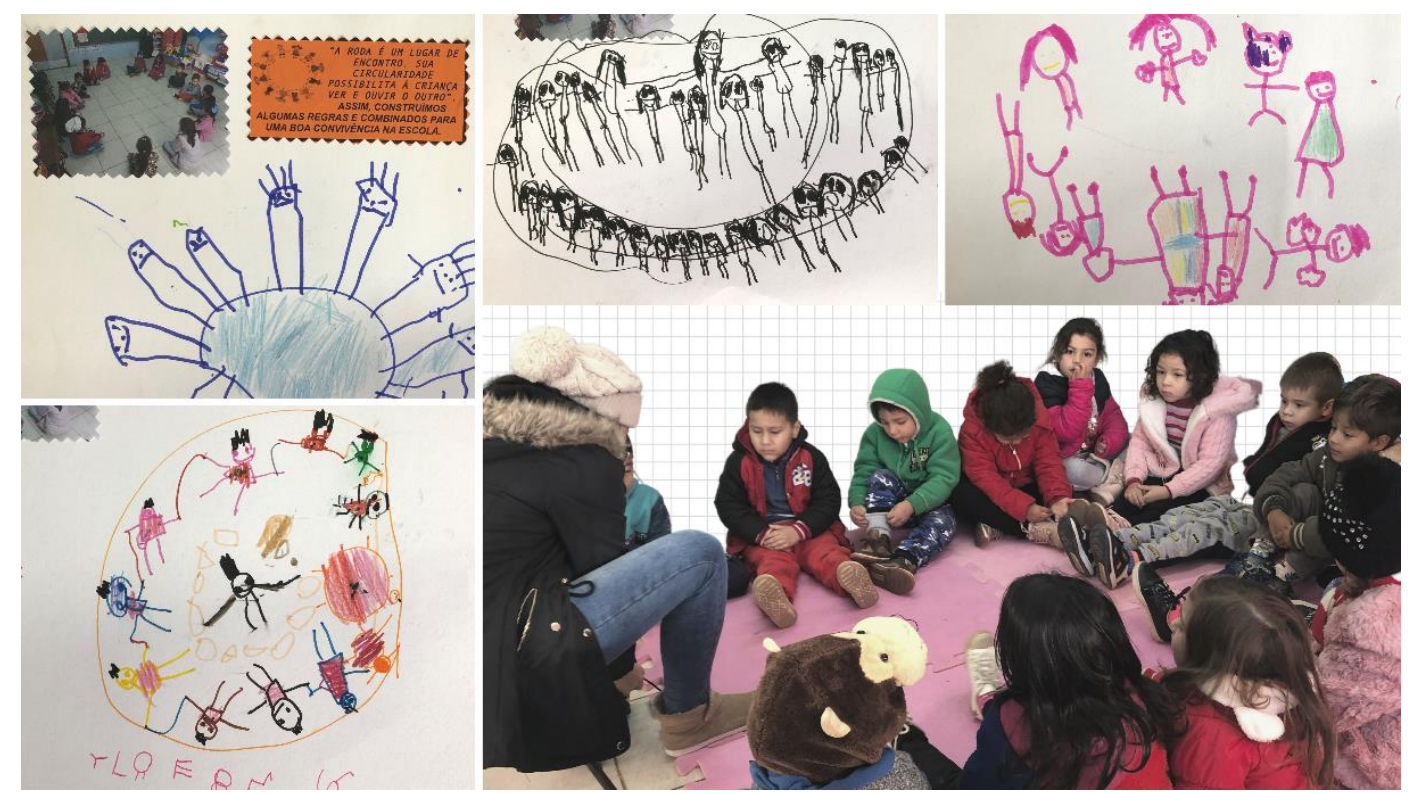

Figura 31 - Construindo o portfólio

Fonte: Acervo da autora.

Malavasi \& Zoccatelli (2019) destacam que os registros escritos que acompanham as imagens não podem se limitar a títulos para atividades e, na composição, não podem ser apenas legenda explicativa para as fotografias ou para os desenhos das crianças. Contudo, verificando a documentação dos quatro grupos, percebeu-se que o padrão mais seguido é de composições com referência direta entre imagem e texto, direcionando a compreensão sobre o que é apresentado.

Outro aspecto relevante à análise da construção dos portfólios, foi a busca por compreender de quem era a tarefa de interpretar as fotografias anexadas a este artefato: as próprias professoras, os pais? E qual o espaço da criança nesse 
processo?

$\mathrm{Na}$ análise, percebemos que os pais possuem protagonismo na tarefa de interpretar as fotografias. Ao imprimirem as imagens e incluí-las às folhas anexadas ao portfólio, as professoras mostram preocupação de deixá-las disponíveis nos varais dos corredores para que pais e familiares das crianças possam ter acesso a esses registros nos momentos de levar e buscar as crianças à escola, conforme explica a educadora:

Franciane (professora/2019) - Conforme as páginas da coletânea vão ficando prontas, elas vão sendo expostas pelo corredor da escola, então quando as famílias vêm buscar as crianças ou deixá-las na escola, sempre visualizam essas fotos. Além disso, eu sempre oriento as crianças para que expliquem aos pais o que estava acontecendo naquela foto, o que elas vivenciaram. Depois disso, tem o momento de entrega da coletânea, no final do ano, que é quando as famílias levam a coletânea pra casa, em definitivo.

Embora as professoras não tenham comentando em entrevista, observouse que as crianças também interpretavam essas fotografias com os pares, em momentos em que se deslocavam pelos corredores da escola para irem de um ambiente a outro.

A pesquisa também pôs luz à participação das crianças no processo de interpretação das fotos que compunham o portfólio, identificado com a análise da categoria "participação". As professoras incluíam à rotina de seu grupo um momento para que as crianças pudessem visualizar as fotos e elaborarem narrativas a partir delas, exemplificado na fala a seguir.

Tchéssika (professora/2019) - Depois que as fotos são impressas, eu disponibilizo para as crianças olharem e colarem nas folhas dos seus portfólios individuais. Nesse momento, eu observo as crianças comentando a respeito das fotos. Elas conversam sobre o momento da atividade. As crianças vão colando do jeito delas e vão observando os momentos já vividos por elas. Depois dessa colagem, a gente costuma expor essas fotos pra comunidade também ver. Nós temos um varal na porta da sala, onde penduramos as folhas do portfólio. É bem gratificante ver que, no final da aula, quando os pais vêm buscar ou quando vêm trazer até a porta da sala, que as crianças mostram e relatam como foi fazer aquela atividade da foto. Isso demonstra que as crianças estão gostando da proposta. Depois de alguns dias, nós guardamos as folhas dentro das caixas e, nesse momento, novamente as crianças comentam, relembrando vivências e atividades que já foram feitas há algum tempo, visualizando as fotos. Esse momento também é muito interessante! No final do ano, então, os portfólios são encadernados e enviados para casa, para os pais. Eu acho isso importante para os pais poderem acompanhar o desenvolvimento da criança nesse período escolar. Para eles, é importante ter esse portfólio em casa pra poderem visualizar por mais tempo as propostas do ano.

Por vezes, esse momento acontecia em paralelo à organização do portfólio 
(Figura 32), permitindo que as próprias crianças colassem as fotos ("do jeito delas") nas folhas de registro. Em entrevista, uma das educadoras comenta que, antes, os portfólios tinham "a cara das professoras", referindo-se ao fato de que, em momento anterior ao processo de reformulação do currículo da escola, havia uma preocupação maior de que o portfólio atendesse a um padrão estético que não correspondia à produção infantil.

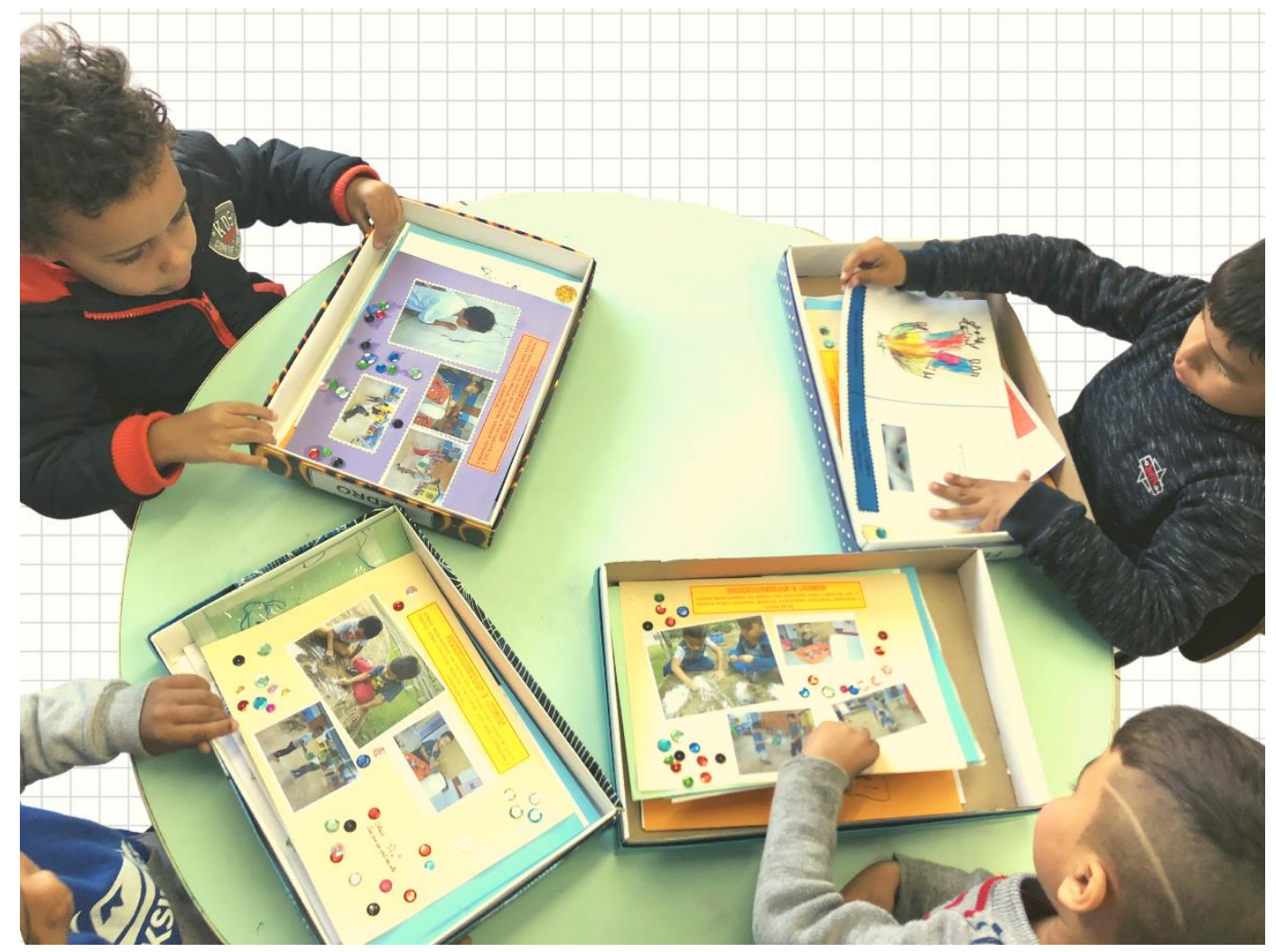

Figura 32 - Interpretando as fotos do portfólio Fonte: Acervo da autora.

\subsection{2}

\section{Portfólios digitais}

O fato de os portfólios das crianças serem entregues às famílias somente ao final do ano letivo, a reflexão por parte das educadoras de que a comunicação entre escola e família precisava se estreitar. As escolas da rede municipal de ensino de Erechim encontraram soluções diferentes para minimizarem essa distância e permitirem que os registros produzidos alcançassem a comunidade com mais frequência. No período em que a pesquisa foi realizada, as escolas 
costumavam abastecer uma página no Facebook $^{59}$ com fotos semanais das crianças. A página era administrada pela equipe de gestão, que divulgava na mídia social os principais projetos da escola.

\begin{abstract}
Andressa (diretora/2018) - Eu acho que o registro é fundamental no meu trabalho, porque dá um norte para sabermos se o trabalho está bom ou não. Com os registros posso avaliar o trabalho que a escola está desenvolvendo. Por exemplo, quando termina um projeto, conferindo as fotos, ouvindo o que uma família diz, ouvindo o que uma professora diz, eu consigo fazer uma avaliação e sei o que é preciso melhorar. E em relação às fotos, também ajudo a administrar da página da escola no Facebook, onde usamos fotos e pequenos textos, pra comunidade acompanhar as atividades da escola. Assim, durante o ano inteiro conseguimos ter um retorno do que as famílias pensam.
\end{abstract}

$\mathrm{Na}$ fala da diretora, percebemos que as fotografias em formato digital se tornaram também instrumento de avaliação do trabalho desenvolvido pela gestão da escola. Com pequenos textos acompanhando as imagens dos projetos temáticos em andamento, as postagens do Facebook informavam à comunidade o que acontecia na escola e permitiam constante interação, por meio de comentários e compartilhamentos do público em geral.

Em 2018, na etapa de observação dos espaços de uso coletivo da escola, foi possível acompanhar o desenvolvimento de um projeto em que as crianças fotografaram seus espaços preferidos da escola. Em momento posterior, as crianças de todos os grupos foram sendo chamadas à secretaria em pequenos grupos e, junto da coordenadora pedagógica, selecionaram no computador uma das fotos que tiraram, e deram um título para essa foto. Com as fotos de todas as crianças impressas, organizou-se uma exposição, que marcou o encerramento do ano letivo e do projeto sobre os 100 anos de Erechim e, também, o aniversário da escola. A vivência foi atravessada pela fotografia em diferentes âmbitos, desde o processo em que as crianças fotografaram os espaços da escola, até os registros do momento da visita da comunidade à exposição e a divulgação desses registros em uma postagem no Facebook (Figura 33).

59 Facebook@ 2020. 
$\leftarrow \quad$ Na EMEI Dom João a fotografia faz

EMEI D. João A. Hoffmann

12 de dezembro de 2018 às 20:43 . (2)

Na EMEI Dom João a fotografia faz parte do cotidiano de sala de aula como um recurso do professor para registrar propostas vivenciadas pelos estudantes. Para comemorar o aniversário da escola, os estudantes fizeram fotografias registrando seu olhar sobre a escola, seus espaços e acontecimentos que encantam a infância. Ainda organizou-se uma linda exposição fotográfica para a apreciação de toda a comunidade escolar.

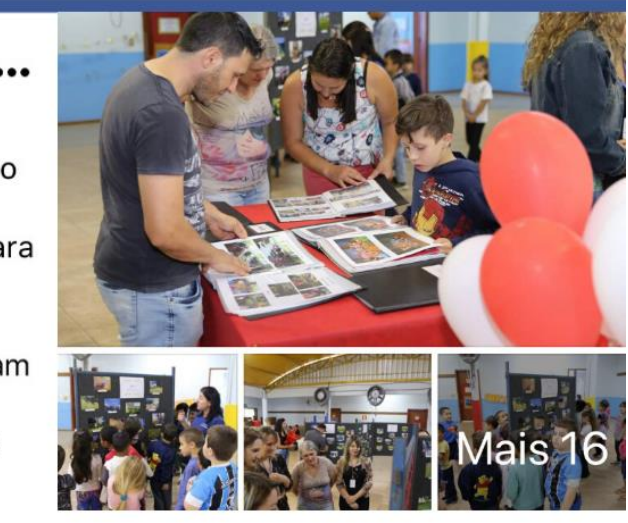

Figura 33 - Documentando pelas mídias sociais 60

Fonte: Facebook@2018 | @emeidomjoaoaloisiohoffmann

Conforme a utilização do Facebook aparecia nas falas das educadoras em entrevistas, adentramos 0 debate sobre a repercussão deste tipo de documentação com as famílias e a comunidade. Durante uma entrevista, em 2018, perguntou-se à diretora como era a recepção das famílias às fotos postadas.

\begin{abstract}
Andressa (diretora/2018) - É muito boa. Não lembro de nenhuma situação

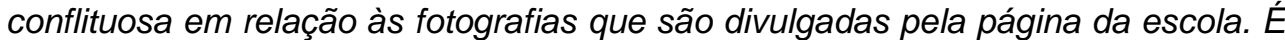
mais positivo do que negativo. As famílias compartilham muito as postagens e adoram comentar. (...) Tenho o cuidado de orientar as professoras para que as fotos sejam mais no coletivo, para que todas as crianças apareçam, porque os pais gostam de ver o filho na página da escola. Então tem que tentar não focar em uma ou outra criança. O ideal é que todo mundo apareça. Tanto é que se você for olhar na página da escola, as fotos são muito mais no coletivo do que individuais.
\end{abstract}

Embora a pesquisa não tivesse o objetivo de fazer uma análise aprofundada das postagens do Facebook, este tipo de documentação mostrou ocupar um espaço relevante na dinâmica da escola, tanto para as gestoras, que administravam a página, quanto para as professoras, que tinham que selecionar, semanalmente, algumas fotos para serem postadas.

Estudos recentes têm indicado que há uma série de vantagens associadas à utilização de imagens e meios digitais para documentar e avaliar a aprendizagem das crianças (Picher, 2019; Beaumont-Bates, 2017; Andrt; Tesar, 2015). Isso inclui a rapidez com que a imagem está disponível para reflexão das

60 EMEI D. João A. Hoffmann (Erechim). Secretaria Municipal de Educação de Erechim. Postagem sobre "Exposição fotos na escola". Erechim, 12 dez. 2018. Elaborada pela Equipe Diretiva da Escola. Facebook: @emeidomjoaoaloisiohoffmann.

Disponível

em: https://www.facebook.com/emeidomjoaoaloisiohoffmann. Acesso em: 20 dez. 2018. 
crianças e do professor, e como a visualização da imagem pode motivar as crianças. A exemplo da proposta desenvolvida na escola, nesses processos há maior possibilidade de participação das crianças, que podem ajudar a selecionar as imagens que melhor refletem os pontos chave do episódio de aprendizagem e de se envolverem ativamente na decisão do que deve ser incluído nas postagens ${ }^{61}$.

Conforme fora dito, esta pesquisa não analisou com profundidade a utilização do Facebook pela escola, mas parece haver um indicativo de que a escola vem percebendo a necessidade de alternativas mais eficazes para 0 compartilhamento de registros com a comunidade, e a plataforma ainda se apresenta como uma plataforma possível e acessível para que isso seja feito. Ainda assim, o fato de o Facebook possuir termos de serviço e privacidade independentes e uma política própria que condiciona os direitos autorais dos dados publicados, ficam lacunas em relação aos direitos sobre as imagens compartilhadas e os limites do uso pedagógico que vem sendo experimentado pelas escolas.

Franciane (coordenadora/2018) - Eu penso que essa que essa seleção das fotos que são postadas na página da escola exige tempo. Exige uma escolha de quais fotos realmente podem ser postadas. Quando essa seleção não é posta como prioridade, pode se tornar um constrangimento para as professoras e também para as crianças.

Em diferentes países, experiências com fotos e vídeos digitais têm estimulado a criação de plataformas desenvolvidas exclusivamente para o compartilhamento de histórias de aprendizagem e dos registros das vivências das crianças (Picher, 2019). Alternativas como essa, poderiam ser interessantes ao trabalho de divulgação da documentação digital da escola em que a pesquisa se realizou, sendo esse um terreno fecundo, que merece ser mais explorado ao nível das investigações acadêmicas e experiências empíricas nos contextos de educação infantil brasileiros.

\footnotetext{
61 Pascal e Bertram (2009) se referem à importância de as crianças falarem sobre seus próprios processos de investigação.
} 


\title{
4.6
}

\section{E os adultos, onde estão?}

A documentação com apoio em registros visuais tem se consolidado como instrumento de comunicação das narrativas e experiências das crianças, mas também pode ser uma oportunidade para que se dê visibilidade ao trabalho dos educadores, visando a conquista de sua valorização profissional (Project Zero; Reggio Children, 2014). Contudo, estando no papel de quem fotografa, muitos educadores tendem a se excluir das fotos, deixando de aparecer em situações que eles próprios ajudam a criar; "educadores que, através da predisposição dos espaços, a oferta dos materiais e da sua presença atenta e sensível, acompanham dia após dia os percursos de crescimento da criança" (Malavasi; Zoccatelli, 2019, p. 68).

Conforme o término da pesquisa-ação foi se aproximando, ficou mais latente a sensação de que as educadoras da escola estavam à sombra da documentação visual. Pelo fato de conduzirem sozinhas as ações pedagógicas junto às crianças, elas raramente eram fotografadas, ficando restritas aos bastidores de suas fotos. Este aspecto foi discutido a partir da dimensão de análise "exposição dos adultos", pondo em evidência a importância do trabalho em equipe para as educadoras da escola.

\begin{abstract}
Andressa (professora/2019) - Em algumas atividades eu quero aparecer na foto, como professora, porque acho importante participar junto com as crianças. Mas ao mesmo tempo, me sinto muito preocupada, pensando quem chamar pra auxiliar. A pessoa que vai fotografar também precisa perceber qual o melhor ângulo ou como enquadrar a foto, pra que as crianças e a professora apareçam realmente envolvidas em determinada atividade. Muitas vezes, abro a porta da sala e peço ajuda para outra colega professora, porque sei que essa professora já tem experiência com a fotografia, já tinha discutido sobre a importância desse registro. Aí, sim, a colega professora consegue registrar e eu sei que depois vou conseguir utilizar a fotografia da melhor maneira.
\end{abstract}

A educadora assume que sente vontade de aparecer na foto, mas para isso precisa do auxílio de outras colegas que estejam disponíveis para fotografar no momento exato em que surge a necessidade, destacando a confiança que é depositada em quem vai fotografar. Segundo ela, nem todas as pessoas da escola estariam aptas a cumprir com essa tarefa. Não bastava ter alguém que pudesse tirar a foto, essa pessoa precisava estar envolvida nas mesmas reflexões sobre fotografia que o grupo vinha fazendo ao longo da pesquisa, para garantir que as fotos produzidas tivessem a mesma qualidade técnica e principalmente 
documental. Esta preocupação também foi percebida em observação:

Uma das professoras comentou estar incomodada com uma situação em relação às postagens do Facebook - agora administradas pela nova gestão. Conforme ela relatou, em dois episódios recentes, as professoras teriam sido fotografadas por colegas da equipe de gestão, em momentos em que estavam envolvidas em atividades com as crianças, sem que percebessem que estavam sendo fotografadas. Algumas dessas fotos teriam sido postadas na página da escola e, segundo essa professora, "algumas colegas se magoaram, porque foram expostas de forma constrangedora". A situação já estaria resolvida, e as fotos que causaram o incômodo parecem ter sido retiradas da página (Nota de campo da pesquisadora, 2019).

Quando saíam da sala para ir a ambientes externos, as educadoras precisavam redobrar a atenção, para não perder de vista as crianças do seu grupo. Como os espaços de uso coletivo geralmente eram usados por mais de um grupo ao mesmo tempo, observar e registrar as experimentações das crianças nesses espaços se tornava um desafio. Entretanto, durante os momentos de observação nesses espaços, foi possível estabelecer uma relação de parceria e cooperação com as professoras, e as fotos produzidas na pesquisa acabaram contribuindo com o processo de documentação das aprendizagens das crianças.

A Figura 34 representa a parceria que estabeleci com as professoras no processo de documentar. Os registros são de 2019. Na ocasião, a professora conduzia uma proposta em que as crianças fotografaram as casas no entorno da escola. Além de conseguir orientar as crianças para o uso da máquina fotográfica, a professora ainda pode aparecer nas fotos. A participação de outro adulto atento à situação de aprendizagem e disponível para registrar, permitiu que a professora se dedicasse exclusivamente à escuta e observação das crianças. 

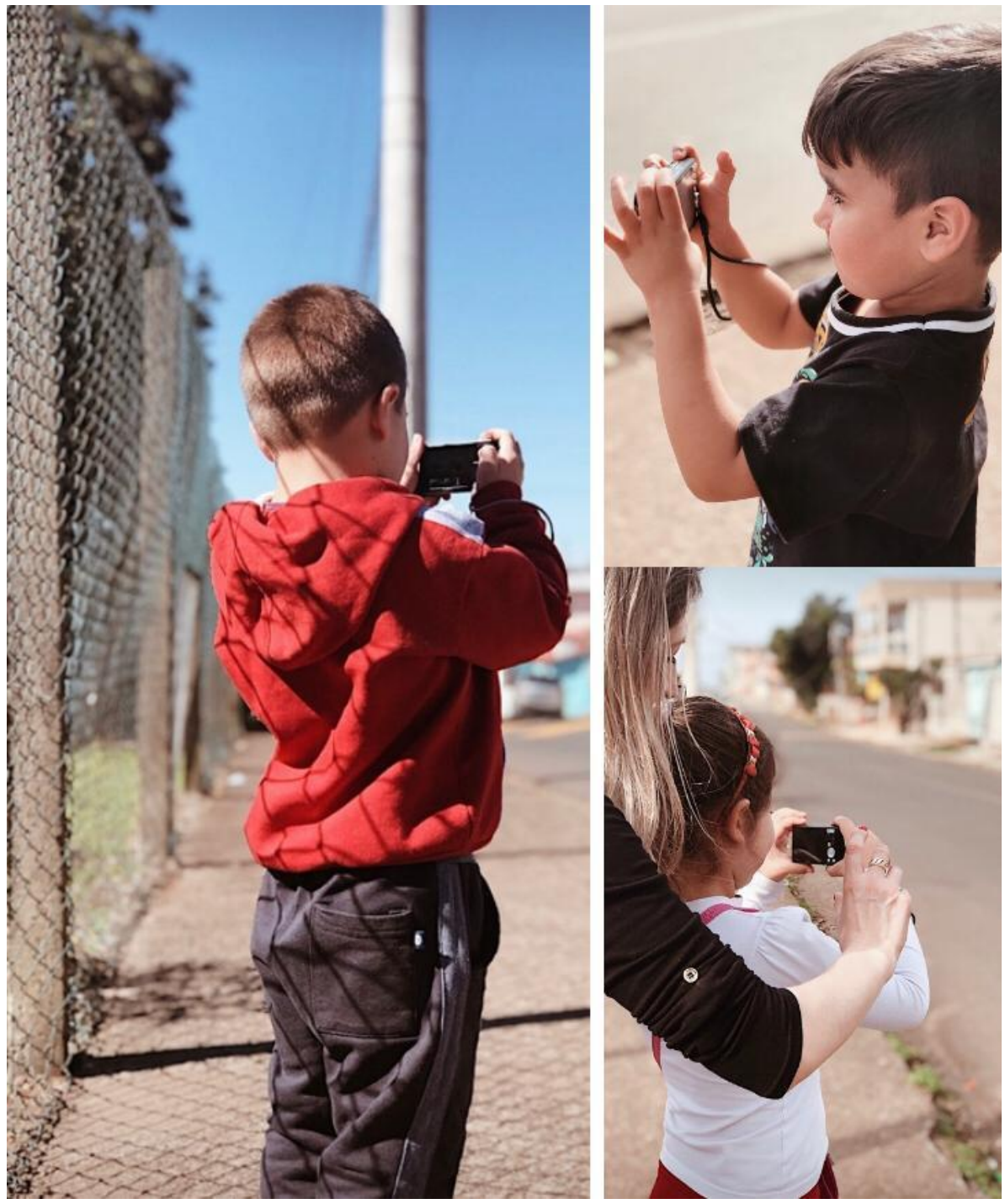

Figura 34 - Fotografando em equipe Fonte: Acervo da autora. 


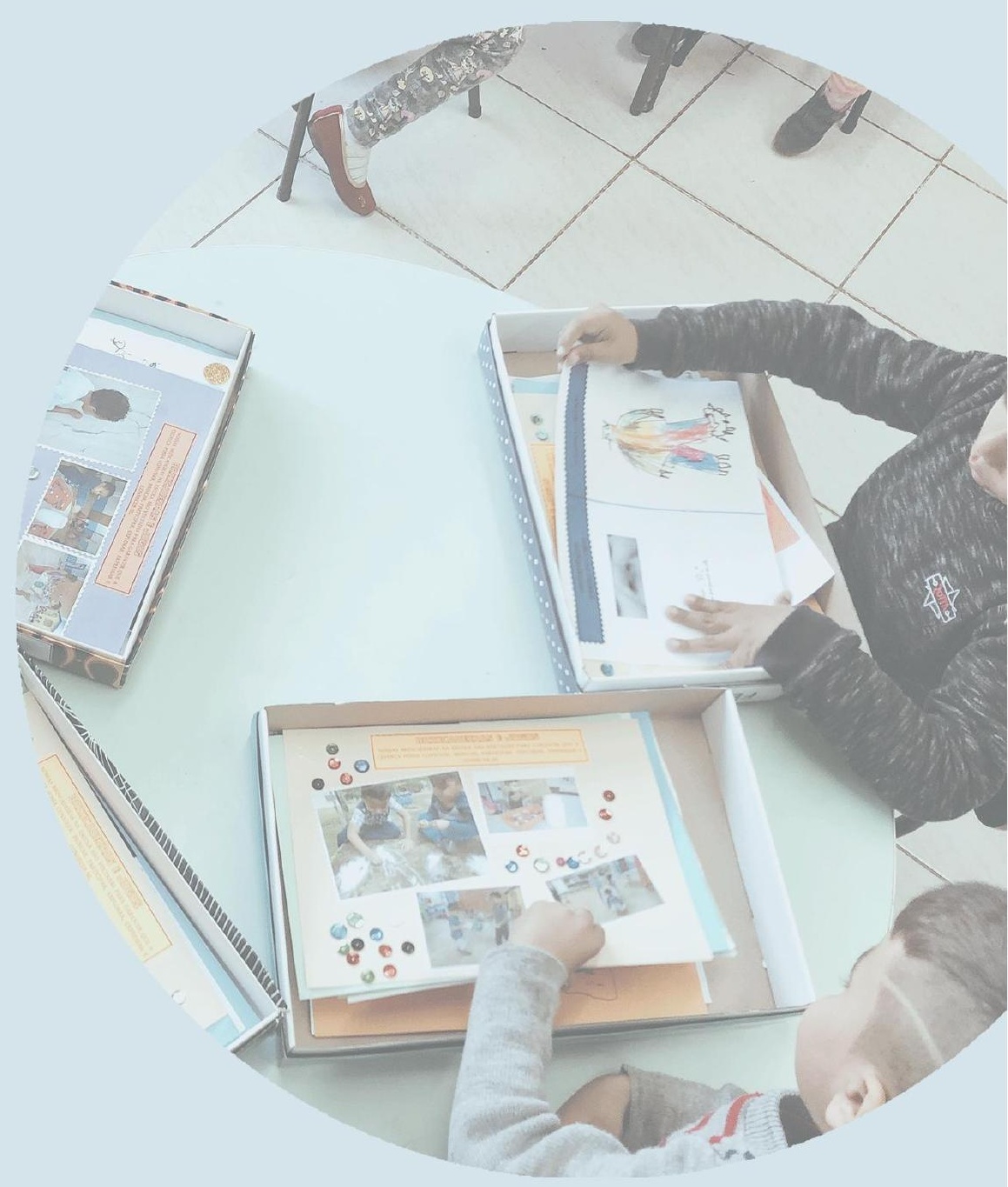

Documentar 


\section{5 \\ Mini-histórias: capturando cenas e atribuindo sentido}

Quando o design da pesquisa foi projetado, esperava-se que a imersão na escola respondesse ao objetivo de compreender os usos que eram dados à fotografia no processo de documentar e narrar as vivências das crianças. Não se tinha expectativa de que a pesquisa proporcionasse ganhos às crianças em relação a conhecimentos sobre a linguagem fotográfica. No entanto, o processo reflexivo e formativo contribuiu para a adaptação do currículo da escola, que foi o ponto de partida para o planejamento de uma série de vivências com a fotografia que envolveram as crianças. Nem todas essas propostas foram pensadas para atender a demandas diretas do processo de documentação, porém são um forte indicativo de que o trabalho focado na sistematização da observação e na produção de registros fotográficos pode contribuir para a construção de aprendizagens com (e pela) linguagem visual. $E$ também a perspectiva inversa: 0 trabalho pedagógico com (e pela) linguagem visual, desenvolvido com a fotografia, pode contribuir com aprimoramento do processo de documentação pedagógica na escola. A Figura 35 ilustra as possibilidades de intersecção entre os conhecimentos nas áreas de abrangência da documentação pedagógica, da linguagem visual e da fotografia, indicando que múltiplas aprendizagens podem ser geradas neste entrecruzamento.

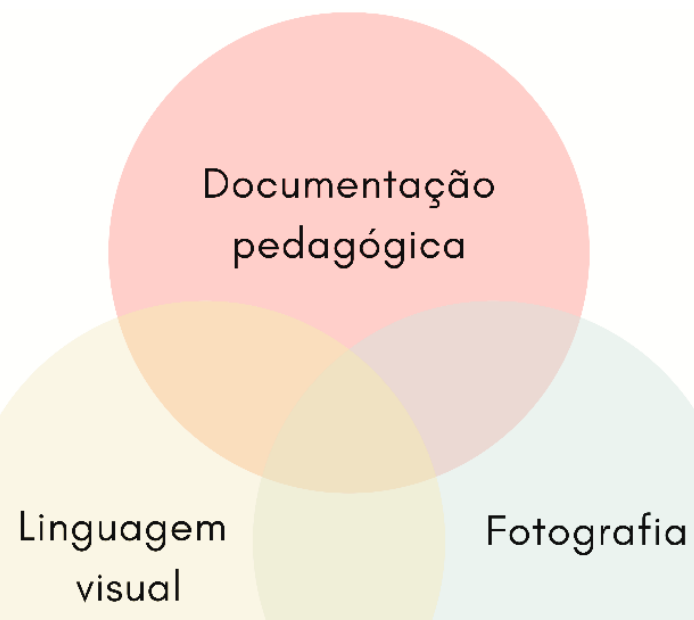

Figura 35 - Intersecções entre as aprendizagens Fonte: Elaborado pela autora. 
As propostas pedagógicas desenvolvidas na escola, que proporcionaram às crianças experiências com a fotografia, foram projetadas a partir do despertar da curiosidade delas próprias com aspectos relativos à linguagem visual e fotográfica. O planejamento destas se desenvolveu a partir do que se entende por currículo emergente ${ }^{62}$, que é

[...] visto como decorrente das observações dos professores sobre as ideias e os interesses das crianças, mas também é elaborado conforme o que os professores pensam que poderá contribuir para o crescimento delas (Gandini; Goldhaber, 2002, p. 154).

$\mathrm{Na}$ abordagem de Reggio Emilia, o currículo emergente vem sendo desenvolvido há mais de cinquenta anos como uma instância viva, permitindo que os percursos de aprendizagem tomem diferentes rumos, dependendo das escolhas que as crianças façam com os pares ou de forma colaborativa com os educadores (Gandini; Goldhaber, 2002; Lino, 2014; Rinaldi, 2017). A adaptação das vivências que já vinha acontecendo na escola decorre da noção de que os projetos pedagógicos são elaborados a partir de objetivos flexíveis,

[...] adaptados às necessidades e interesses das crianças, os quais incluem aqueles expressados por elas a qualquer momento durante o projeto, bem como aqueles que os professores inferem e trazem à baila à medida que o trabalho avança (Rinaldi, 2017, p. 113).

Essa etapa de análise se configura como estrutura complementar à discussão dos resultados que compõe os capítulos anteriores, e será apresentada no formato de mini-histórias - pequenas narrativas com apoio em fotografias, que constituem uma forma de comunicação dos processos de escuta e documentação em instituições de educação de infância. A metodologia vem sendo desenvolvida, desde 1985, pelas creches e pré-escolas de Reggio Emilia, tendo sido, inicialmente, acompanhada de perto pelo precursor da proposta, Loris Malaguzzi. Juntamente com outros tipos de documentação, as mini-histórias se apresentam como uma proposta sensível de compreender o ponto de vista das crianças sobre o percurso de construção de suas aprendizagens (Reggio Children, 2020).

No Brasil, a proposta de documentar com mini-histórias vem sendo

\footnotetext{
62 A escola trabalhava com perspectivas de currículo próximas a esta, tendo sido atribuída por mim a proposta de currículo emergente. Alguns termos usados anteriormente pelas educadoras para se referirem ao currículo da escola, eram: currículo construtivista; centros de interesse da criança; currículo alternativo.
} 
adaptada por Paulo Fochi, em atuação à frente do Observatório da Cultura Infantil $(\mathrm{OBECl})^{63}$ - um grupo gerido de forma autônoma, formado por educadores interessados em discutir o cotidiano da educação infantil e a formação de professores, e que vem promovendo iniciativas de reflexão e experimentação de práticas educativas alternativas, com escolas de quatro municípios do Rio Grande do Sul - Porto Alegre, Canoas, Novo Hamburgo e Veranópolis. Fochi (2019, p. 49) pontua que o OBECI tem tratado as mini-histórias como

[...] rapsódias da vida cotidiana que, ao serem narradas textual e imageticamente, tornam-se especiais pelo olhar do adulto que as acolhe, interpreta-as, e dá valor para a construção da memória pedagógica.

O aspecto determinante para a escolha da metodologia de mini-histórias, foi a possibilidade de dar destaque às fotografias produzidas por mim ao longo da pesquisa-ação, que não tiveram suas complexidades exploradas nas categorias da análise de conteúdo e que ganharam sentido com a elaboração do mosaico de significações (Figura 19, p. 101). O que estas imagens têm em comum, é que todas ajudam a contar como foi o percurso de aprendizagem das crianças, a partir das experimentações com a linguagem visual e fotográfica.

Pode-se dizer que esta não foi uma escolha metodológica neutra e, sim, um reconhecimento pessoal meu, enquanto pesquisadora, na tarefa de fotografar e documentar o contexto da escola na pesquisa - sensibilidade construída ao longo dos anos de experiência como educadora de infância, aguçando os sentidos para uma escuta plena das crianças.

O olhar para a fotografia na pesquisa se assemelha ao fazer pedagógico de educadores adeptos da proposta de mini-histórias. Cada uma destas pequenas narrativas opera como lente de aumento, não apenas para uma experiência particular de quem fotografa, mas para as vivências protagonizadas pelas crianças ao longo da pesquisa. Desta forma, o percurso narrado tornou-se cooperativo, compartilhado e coautoral, o que marca uma diferença importante na comparação das mini-histórias com outros gêneros de narrativas visuais, que preconizam exclusivamente a perspectiva do fotógrafo/narrador. Spaggiari (2020) reafirma a ideia de que a sensibilidade para a linguagem fotográfica, necessária às minihistórias, diverge substancialmente de outros gêneros, como as crônicas instrutivas/unidimensionais.

\footnotetext{
63 Outras informações sobre o OBECl estão disponíveis em: https://www.obeci.org/
} 
Para fotografar as crianças, a relação entre elas e o que estão fazendo, requer-se atenção inalienável por parte do adulto, bem como uma abertura ao inesperado. Requer conhecimento não apenas das crianças, mas sobre a linguagem da fotografia para se capturar, destacar e dar expressividade aos acontecimentos que se procura descrever [...]. Pode-se aprender a ver, em vez de apenas olhar; essa é uma prática valiosa para se desenvolver uma educação visual sensível, que pode ter repercussões notáveis na abordagem didática do cotidiano (SPAGGIARI, 2020, p. $x$ vii $\left.{ }^{64}\right)$.

O layout das mini-histórias foi projetado em uma plataforma online de design gráfico, chamada Canva@ ${ }^{65}$

\begin{abstract}
que permite aos usuários criar gráficos de mídia social, apresentações, infográficos, pôsteres e outros conteúdos visuais. Está disponível online e em dispositivos móveis e integra milhões de imagens, fontes, modelos e ilustrações. Os usuários podem escolher entre muitos modelos projetados por profissionais, editar os designs e fazer upload de suas próprias fotos através de uma interface de arrastar e soltar. A plataforma é gratuita e assinaturas pagas, como o Canva Pro e o Canva for Enterprise, oferecem funcionalidade adicional. Os usuários também podem pagar por produtos físicos a serem impressos e enviados (Canva Company Profile, 2020, n.p).
\end{abstract}

O Canva também oferece alguns templates no formato de newsletter, específicos para escolas organizarem fotos digitais e textos e compartilharem com as famílias. No entanto, as mini-histórias elaboradas aqui, foram criadas de forma livre, sem a utilização de um modelo padrão, o que envolveu um processo estético/criativo de atribuição de sentido às imagens, na perspectiva proposta por Didi-Huberman (2013; 2015).

A seguir, são apresentadas oito mini-histórias, elaboradas a partir de hipóteses sobre a linguagem fotográfica, levantadas pelas crianças durante pesquisa. As fotos e os demais registros foram feitos por meio de diferentes estratégias metodológicas de cunho participativo durante a observação, tornandose evidências, que ajudam a traçar percursos individuais e coletivos das experiências vividas pelos sujeitos na pesquisa.

\footnotetext{
64 Spaggiari (2020), paginação em formato E-pub/Kindle.

65 Canva Pro® 2020. O software foi fundado em 2012, por Melanie Perkins (CEO), Clifford Obrecht e Cameron Adams, tendo sua sede em Sydney, Austrália.
} 


\section{1}

\section{Mini-história I}

19.11.2018 | Experimentações com uma câmera fotográfica profissional

\section{DESCOBERTAS COLETIVAS}

- Laniely e Anthony, 4 anos

Na roda de conversa

Todo mundo ama estar

Mas espero minha vez

Falta muito pra chegar?

Uma câmera bonita

Que pra mim é novidade

Mas a minha profe diz:

"Cuidado, é de verdade!"

Seguro com toda força

e olho pelo buraquinho

Você tem que ver isso

Espia aqui, bem rapidinho!

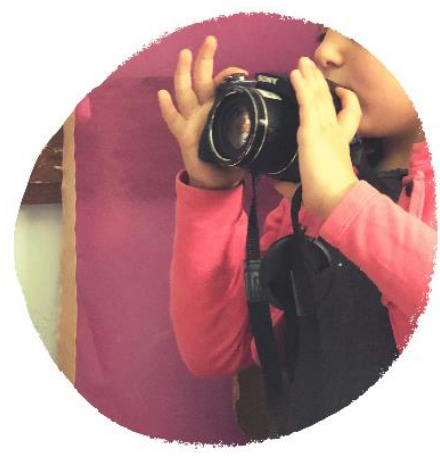

ISSO

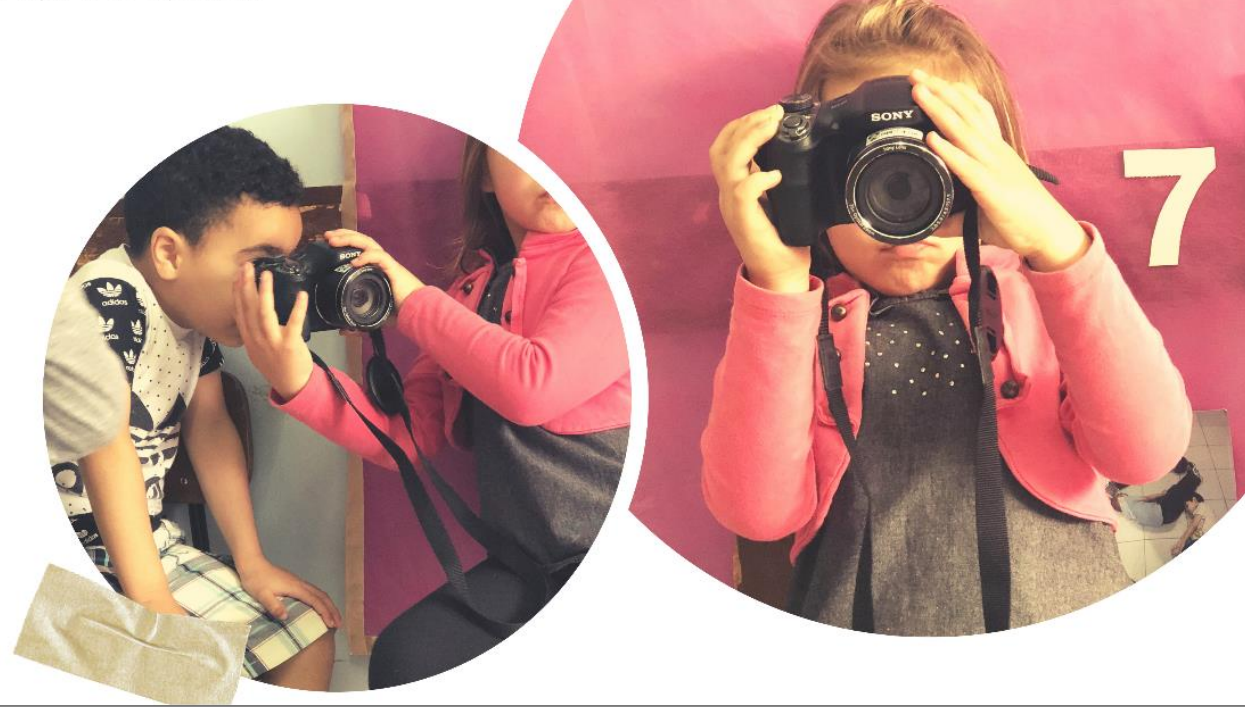

Figura 36 - Mini-história I

Fonte: Elaborado pela autora. 
A Mini-história I (Figura 36) possibilita a visibilidade de descobertas individuais e coletivas das crianças com a fotografia. Durante a pesquisa, foram desenvolvidas propostas em que as próprias crianças tiravam fotos, usando câmeras digitais ou aparelhos celulares. A primeira proposta era de que as crianças fotografassem seus espaços preferidos da escola, mas antes de cada sessão as professoras conduziam um momento em sala para que as crianças conhecessem os equipamentos. A experiência coloca em evidência a materialidade e imaterialidade destes processos, no que tange as aprendizagens possibilitadas no tocar, segurar, olhar, sentir, explorar.

$\mathrm{Na}$ experiência narrada na primeira mini-história, as crianças aguardam em círculo para ver de perto uma câmera fotográfica profissional trazida para a escola pela professora. As crianças passam a câmera para o próximo colega da roda com cuidado, alertadas pela professora de que é uma "câmera de verdade", "que estraga se cair no chão". Percebo que as crianças têm dificuldade de segurar a câmera sozinhas, pois o peso, as dimensões e a funcionalidade do equipamento não foram pensados para o uso infantil. Nem todas as crianças ficam satisfeitas com a experiência, algumas passam a câmera adiante rapidamente, outras perdem o interesse antes mesmo de sua vez chegar.

Uma das crianças que conseguem segurar a câmera e testar alguns cliques, convida o colega ao lado para compartilhar a experiência. As crianças querem conhecer e experimentar, mas a parceria compartilhada parece enriquecer sua experiência.

De que vale saber, descobrir, se não tiver com quem compartilhar? O que as crianças veem pela lente da câmera? O que escolhem fotografar? Todas as crianças desejam fotografar? No senso comum, tem-se impressão de que as crianças aprendem sozinhas a utilizar computadores, tablets e celulares, pois já nascem cercadas desses equipamentos tecnológicos, mas será que todas elas "sabem" fotografar? 
5.2

\section{Mini-história II}

\section{ALÉM DO QUE OS OLHOS ALCANÇAM}

Isabelli, 5 anos Stefany, 5 anos

Chegando à sala de AEE, a professora lembra: "É só apertar o botão grande na hora de tirar a foto". Mas a sala tem tantos brinquedos, "e se antes das fotos brincarmos um pouquinho?"...

... O tempo já está terminando, e as fotos?

Sem querer abandonar a brincadeira Isabelli criou uma forma inusitada de fotografar..

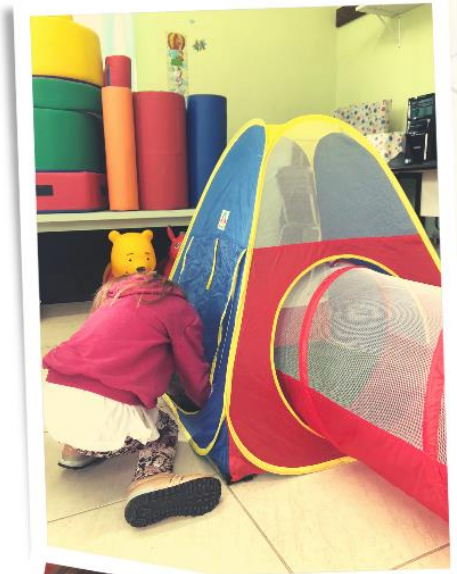
o com as duas mãos, tirou uma foto; depois, aproximou o celular de volta para si para ver a foto que tinha tirado. Parece que a foto não ficou como ela esperava. Repetiu a tentativa outras duas vezes, mas a estratégia não parecia funcionar.

A Isabelli lembrou da dica da professora e pôs o dedo no botão grande antes de colocar o celular dentro da barraca. Depois da quarta tentativa, com muita concentração... deu certo!

Saiu correndo para compartilhar a descoberta: "Sabia que tem um monte de bolinhas coloridas lá dentro?". Que ideia genial! A Stefany adorou a ideia e decidiu fotografar as bolinhas ao lado.

22.10.2018 | Fotografando os espaços de uso coletivo da escola.

Figura 37 - Mini-história II Fonte: Elaborado pela autora. 
A Mini-história II (Figura 37) narra os passos de uma descoberta feita durante outra vivência em que as próprias crianças fotografavam. As professoras tinham feito uma espécie de triagem, perguntando às crianças sobre quais os seus espaços favoritos da escola, para a partir disso organizar pequenos grupos e sair da sala para fotografar. Por coincidência, no dia em que eu observava a sala de AEE, chegou um grupo de crianças para fotografar aquele ambiente. Aguço a curiosidade para entender por que as crianças teriam escolhido aquela sala como preferida, se era um espaço que elas não frequentavam, destinado apenas ao atendimento especializado.

A professora de AEE, sabendo que receberia o grupo em sua sala, havia disposto vários brinquedos pelo chão e nas mesas, como uma exibição dos materiais que a sala dispunha. As crianças não disfarçaram os olhares de encantamento para os brinquedos espalhados por todo lado. Ao explorar o ambiente, a curiosidade de ver o que estava dentro da barraca parece ter levado à descoberta de que a lente da câmera pode alcançar espaços que os olhos humanos não conseguem chegar.

Até onde vão os "olhos" da câmera? O que mais posso ver através deles? 
5.3

\section{Mini-história III}

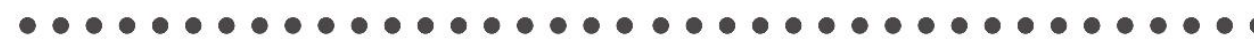

1 Faz poucos dias que descubro um mundo

todo novo. A primeira vez fora de casa. A

primeira vez em uma escola. A primeira vez longe da mamãe e da mana. São tantas novidades, que não sei por onde começar. No parque, sinto o perfume do chão de terra, o vento gelado do inverno cortar meu rosto e o sol forte me esquentar. Não quero entrar. É aqui fora que gosto de estar. A natureza se mistura aos gritos das crianças. As vezes me assusto, pra que tanta confusão?

- Arthur, 4 anos

por Elise de Moraes

As crianças ajudam a pensar: como guardar essas lembranças, se as fotos $\circ$ Arthur não pode enxergar? Como faremos, alguma sugestão?

\section{JÁ SEI! ELE PODE VER A COM A PONTINHA DOS DEDOS}

- Suiani, 4 anos
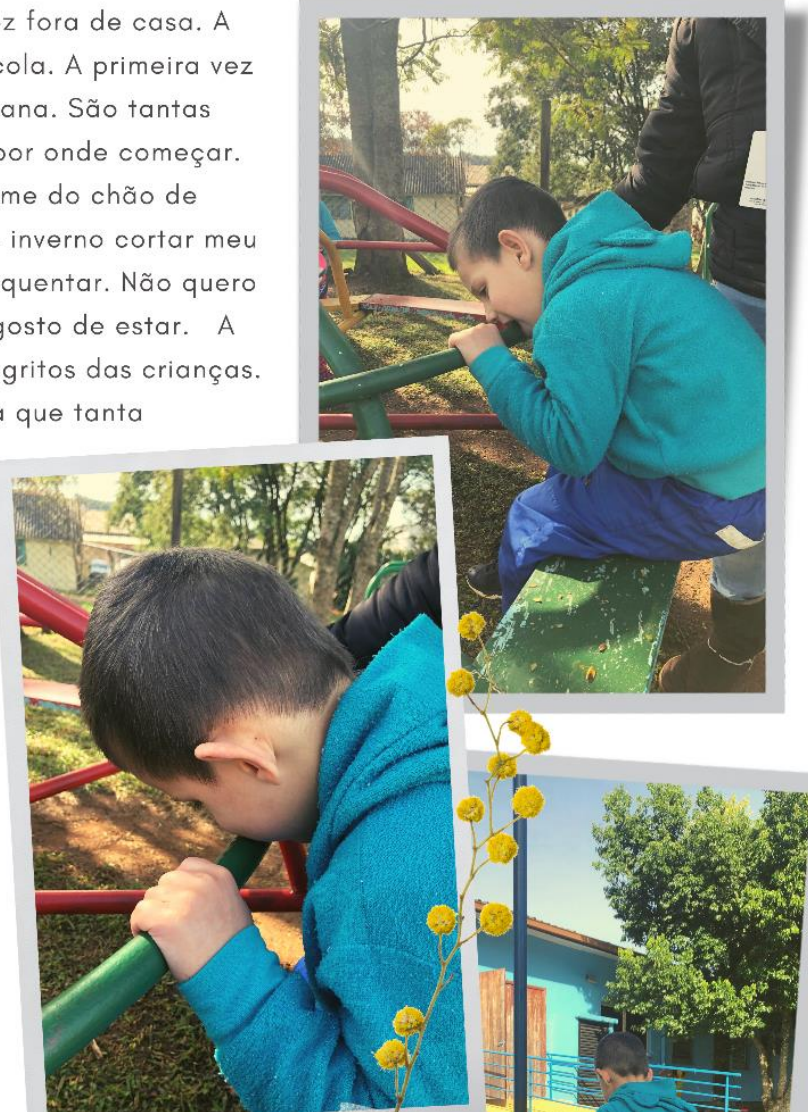

res
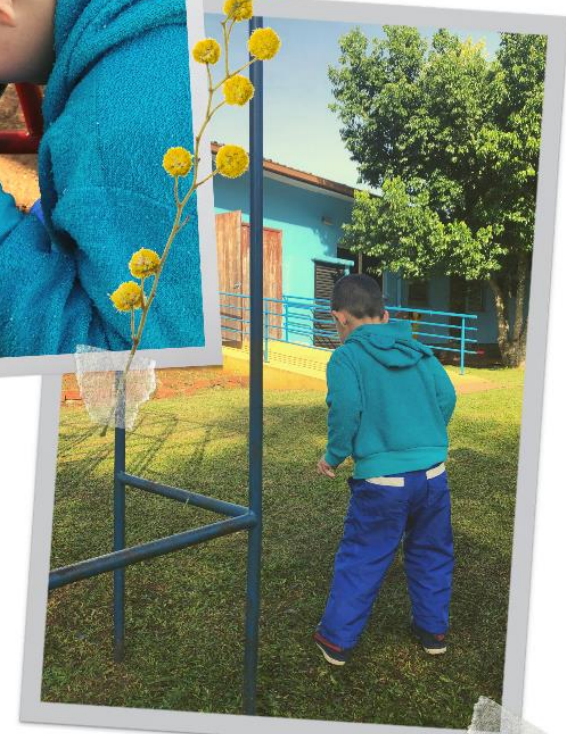

06.06.2019 | Registros de observação | Grupo Rosa - Professora Tchéssika

Figura 38 - Mini-história III

Fonte: Elaborado pela autora. 
Na Mini-história III (Figura 38), a fotografia dá visibilidade ao processo de inclusão e adaptação de uma criança recém-chegada à escola. Ao completar 4 anos de idade, ela passa frequentar a pré-escola por obrigatoriedade - o que marca a primeira grande ruptura na vida dessa criança, que até então convivia apenas com a mãe e a irmã.

A Prof. - Tchéssika se depara com diversos desafios, ao ser informada que a criança era deficiente visual e que também havia suspeita de deficiência auditiva. Ela busca alternativas em relação à documentação e produção de registros fotográficos do processo de adaptação e inclusão. As outras crianças do grupo participam, criando hipóteses a partir das experiências de acolhimento e convivência com o novo colega. O processo acende na escola a discussão sobre a construção de modelos avaliativos que também sejam capazes de ser inclusivos.

Como "mostrar" as fotografias às crianças com limitação visual e auditiva? Que outros mecanismos podem ser usados para que haja participação de todas as crianças no processo de fotografar, documentar e narrar? 


\section{4}

\section{Mini-história IV}

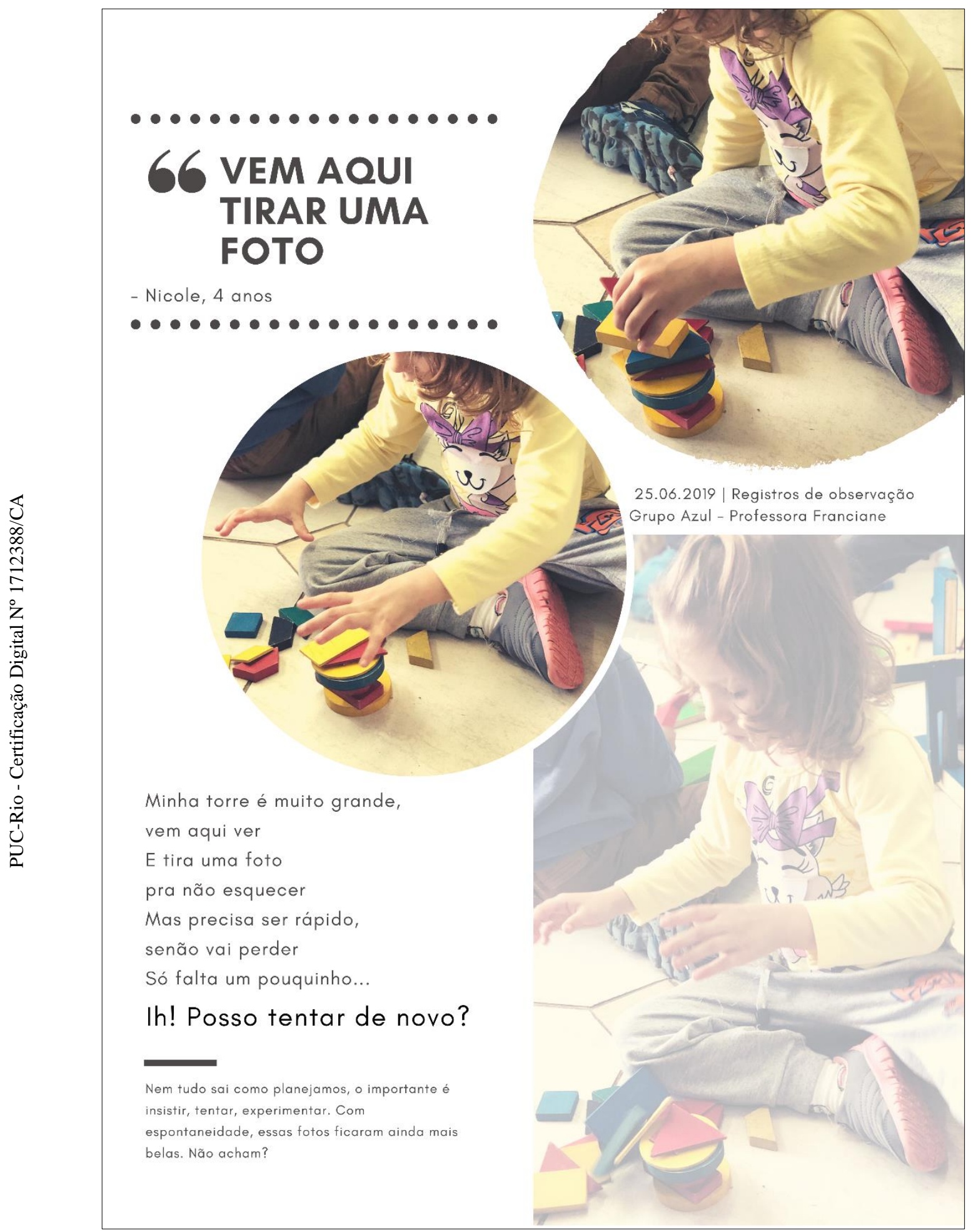

Figura 39 - Mini-história IV

Fonte: Elaborado pela autora. 
Na Mini-história IV (Figura 39), narra-se uma situação que se tornou recorrente na pesquisa: as próprias crianças passam a solicitar às professoras que tirem fotos suas. O convite ao adulto acontece quando as crianças constroem descobertas que consideram grandiosas ou apenas para atrair a atenção das professoras para si. O mesmo acontece nos momentos em que observo suas vivências, torna-se comum as crianças se aproximarem para pedir que se tire fotos ou para ver no visor da câmera o resultado da foto produzida.

"Vem aqui tirar uma foto!" ou "Você já tirou uma foto do meu castelo?". As crianças parecem ter compreendido ao longo da pesquisa que as fotos guardam os momentos mais valiosos.

Contudo, teriam as crianças adquirido uma "consciência" da função social das fotos como memória do que é vivido na escola? Qual a real compreensão das crianças sobre o papel dos registros fotográficos? 
5.5

\section{Mini-história V}

COMO LEMOS AS IMAGENS?

6 - Essa foto é do dia que achei uma pena lá no parque. _É uma pena de galinha!

_ Como tu sabe, se tu nem tá na foto?

_ Prof., né que eu não faltei na escola nesse dia?

As crianças

criaram uma

hipótese de que

só quem

aparece nas

fotos participou

da situação

vivida. Será?

Precisamos

pensar mais

sobre isso..

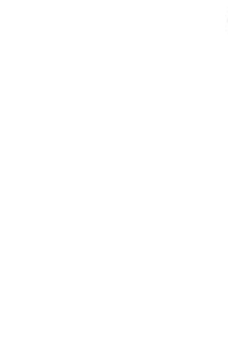

09.08.2019 | Falas registradas em roda de conversa, enquanto as fotos eram exibidas na televisão

| Grupo Rosa - Prof. Tchéssika

- Avaliação da pesquisa com as crianças

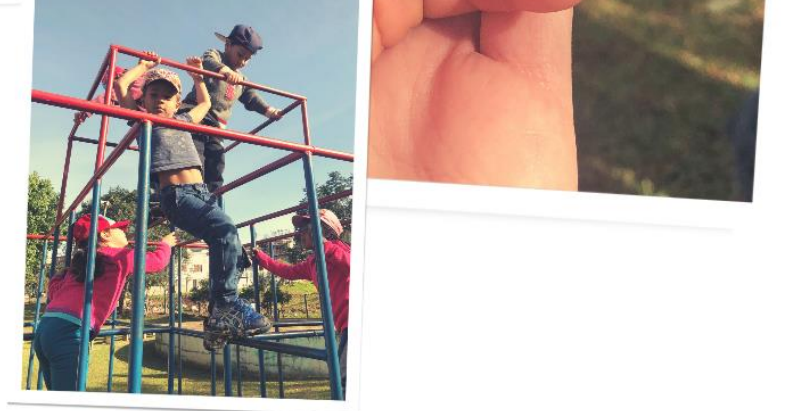

Figura 40 - Mini-história $\mathrm{V}$ Fonte: Elaborado pela autora. 


\section{6}

\section{Mini-história VI}

\section{O QUE A FOTO MOSTRA?}

Fomos brincar com argila, lá fora, perto do parque.

- Maria, 4 anos

Eu fiz uma panela, igual a dos índios.

- Antonella, 5 anos

O Érique fez um homem pelado. - Monique, 5 anos

É que ele tava tomando banho. - Érique, 4 anos

O cachorro entrou na escola, mas ele não mora aqui.

- Monique, 5 anos

15.08.2019 | Falas registradas em roda de conversa, enquanto as fotos eram exibidas na televisão | Grupo Rosa - Prof. Tchéssika - Avaliação da pesquisa com as crianças

Figura 41 - Mini-história VI Fonte: Elaborado pela autora. 
Nas Mini-histórias V (Figura 41) e VI (Figura 42), "ouvimos" as crianças a respeito de sua leitura das imagens fotográficas. As falas foram registradas durante as rodas de conversa que permitiram que as crianças avaliassem sua participação na pesquisa e recordassem algumas vivências. A intenção era saber as impressões e memórias delas sobre as situações vivenciadas ao longo da pesquisa, a partir das imagens exibidas em formato digital. Nestas sessões, havia liberdade para falar sobre temas de seu interesse, suscitados a partir das propostas que vinham sendo conduzidas pelas professoras ao longo da pesquisa.

As crianças constroem narrativas a partir do que estão vendo nas fotos e mesclam suas memórias individuais com a realidade, com o que de fato aconteceu na ocasião representada em cada foto. As narrativas são coletivas, cada criança acrescenta pontos à sua fala a partir da fala do outro. Algumas hipóteses são levantadas, havendo necessidade de intervenção do adulto.

As questões possibilitadas são: Apenas quem aparece na foto participou da situação vivida? Que outras leituras as crianças fazem das imagens? Como se constrói memória a partir das fotos? Quais as concepções temporais as crianças têm ao interpretarem as fotos? 
5.7

Mini-história VII

Projeto desenvolvido de junho a agosto de 2019.

66 COMO VOCÊ CONSEGUE COLOCAR A FOTO NO PAPEL?

- Davi, 5 anos

- $\bullet \bullet \bullet \bullet \bullet \bullet \bullet \bullet \bullet \bullet \bullet \bullet \bullet$

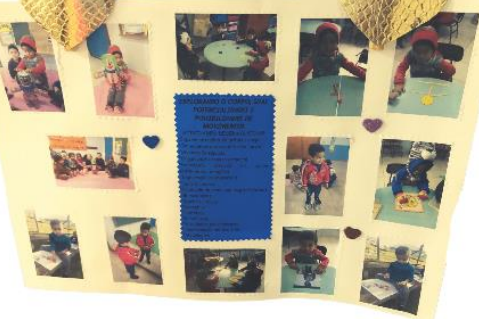

A curiosidade do Davi e de outras crianças a respeito das fotos coladas nas folhas do portfólios, deu origem a um projeto sobre o "caminho das fotos até chegarem no papel".

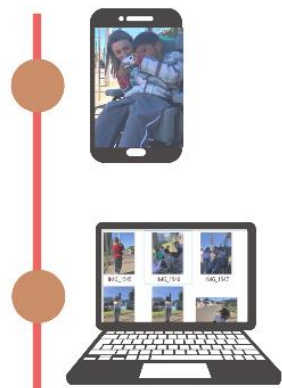

Fotografamos as casas ao redor da escola, com celular ou câmera digital.

Selecionamos as fotos no laptop das professoras.

Passamos as melhores fotos para um pendrive.

\section{Levamos o pendrive} 덜 até o computador da secretaria.

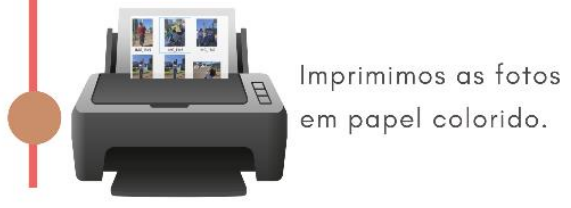

Atividade realizada com as turmas de Pré-A da escola. Professoras: Andressa, Franciane, Inajara e Tchéssika

Figura 42 - Mini-história VII Fonte: Elaborado pela autora. 
5.8

Mini-história VIII

\section{PARA ALÉM DA ESCOLA}

\section{PASSEIO AO ESTÚDIO FOTOGRÁFICO}

22.08. 2019

Depois de desvendar alguns mistérios da fotografia em nossa escola, decidimos visitar um lugar que faz outros tipos de foto, a Zardo Fotografia, um estúdio fotográfico que fica no centro de nossa cidade.

De ônibus, passamos por vários pontos importantes de Erechim, mas o que mais nos encantou foi o Castelinho e o chafariz da Praça da Bandeira.

No estúdio, descobrimos que existe uma profissão para quem tira fotos, que se chama fotógrafo(a). Conhecemos as salas onde as fotos são tiradas, editadas e impressas. Ao final do passeio, tivemos uma grande surpresa: vimos de pertinho um drone voar! Vibramos vendo ele lá em cima, pertinho dos prédios... Mas agora temos um novo mistério para desvendar:

como ele conseguiu tirar fotos nossas "sozinho"?

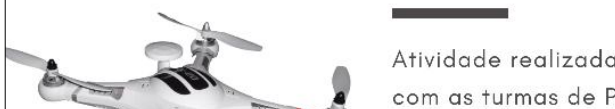

com as turmas de Pré-A da escola. Professoras: Andressa, Franciane, Inajara e Tchéssika

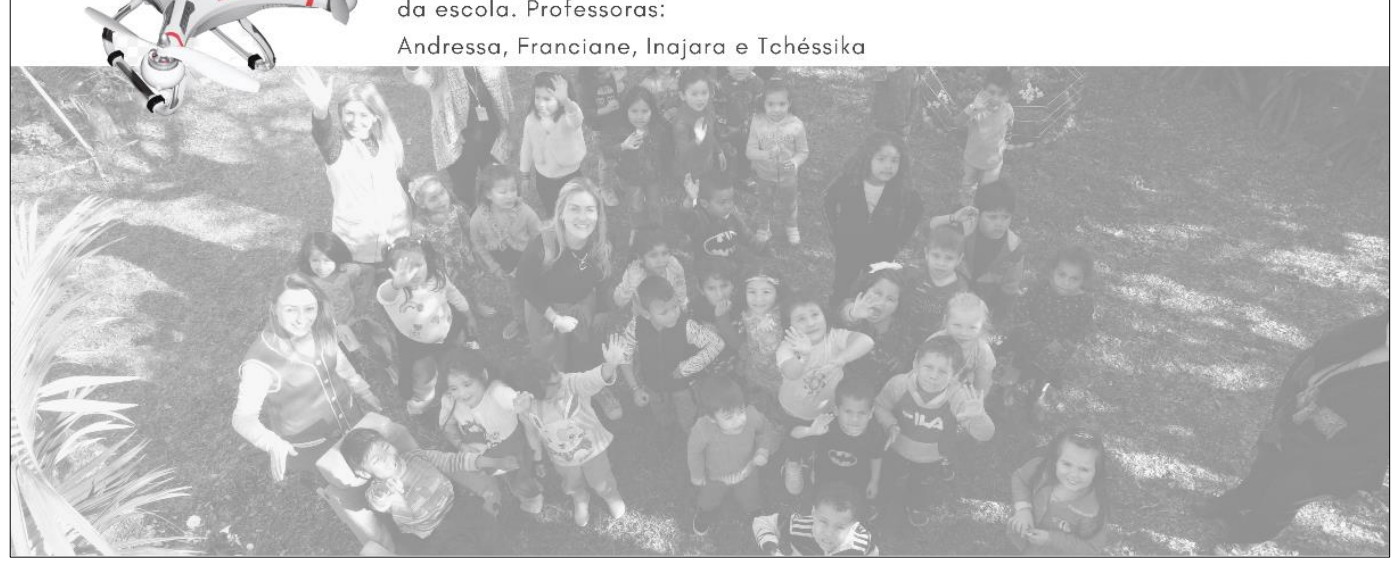

Figura 43 - Mini-história VIII Fonte: Elaborado pela autora.
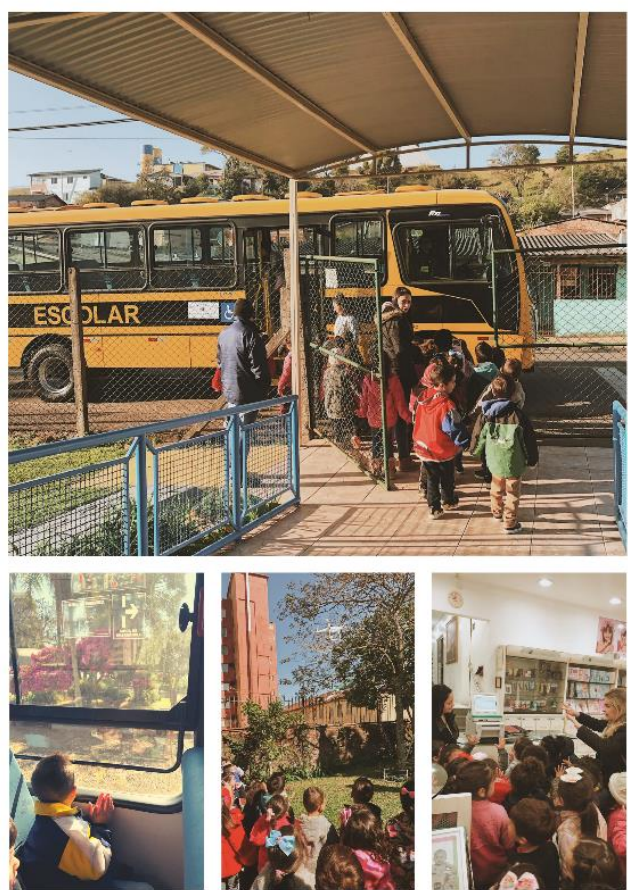
A situação que deu origem às Mini-histórias VII (Figura 42) e VIII (Figura 43) partiu da curiosidade de uma criança a respeito das fotos que eram coladas no portfólio. "Como você colocou a foto no papel?", foi a pergunta feita à Prof. Franciane, que de imediato respondeu que as fotos tinham sido "impressas". A Prof. a Andressa também tinha recebido uma pergunta semelhante dias antes em seu grupo, e havia dado a mesma resposta.

Nas semanas seguintes, refletirmos sobre o que as crianças poderiam ter compreendido por "foto impressa" e iniciamos uma discussão sobre a fotografia e sua materialidade. Debatemos sobre a distância geracional já determinada entre nós, adultos, e as crianças na educação infantil. Quando pensamos em foto, automaticamente lembramos dos álbuns de família, das fotos da nossa infância ("lembranças dos aniversários com balão surpresa, das férias na praia e dos primos que não vemos com frequência..."). As professoras concordam que esses álbuns antigos, hoje amarelados e com "cheiro de guardado", ainda rendem ótimos momentos quando a família se reúne para revê-los. Percebemos que nossa geração tem maior relação com a foto impressa, materializada no papel; enquanto as crianças possivelmente compreendiam que foto é em formato digital, geralmente tirada pelos pais, com a câmera do celular ou do tablet.

O debate motivou a elaboração de um projeto que investigou com as crianças como as fotos são impressas, qual o "caminho da foto até chegar ao papel". A narrativa do percurso coletivo, contada através da sétima mini-história, traz inúmeras possibilidades de ampliação a esta proposta.

Que outras curiosidades e dúvidas as crianças têm em relação à linguagem fotográfica? Quando se fala em foto, a criança imagina a foto no papel ou a foto digital? E as educadoras? Que diferenças significativas há entre as concepções de foto das professoras e das crianças?

Com o projeto desenvolvido, as aprendizagens sobre fotografia se expandem para além dos portões da escola. Conforme demonstra a oitava minihistória, as crianças fizeram um passeio de ônibus para visitar um estúdio fotográfico, onde elas foram apresentadas a novos ambientes e equipamentos, e ouviram explicações sobre edição e impressão de fotos. Nem tudo no estúdio é adaptado às crianças - tamanhos, alturas, proporções... algumas explicações fogem de seu entendimento, mas o drone, que não estava previsto no cronograma da visita, rouba a cena e ganha a atenção das crianças. 
Que equipamentos para captura de imagem são adequados às crianças? Como tornar acessível às crianças a ideia de que o drone não fotografa "sozinho"? Que outras dúvidas e curiosidades as crianças têm em relação aos equipamentos fotográficos? É possível responder a estas questões realizando uma pesquisa?... 


\section{6 \\ Considerações finais}

O estudo realizado e apresentado teve como objetivo compreender e analisar a utilização da linguagem fotográfica no processo de documentar e narrar as vivências e aprendizagens das crianças na educação infantil. Para alcançar este objetivo, foi necessário responder a sete questões centrais que foram apresentadas ao início da tese. As questões foram sendo debatidas, construindo uma base sólida de conhecimento sobre as crianças e os processos que vão dando visibilidade às suas aprendizagens no contexto da escola. Estas descobertas podem ter repercussões ambivalentes para diferentes áreas do conhecimento: educação, mídias e os estudos da infância. Assim, importa recordar as perguntas formuladas previamente, que foram responsáveis pelo dimensionamento da tese e, a partir delas, refletirmos sobre a discussão promovida.

\section{1) A que processos se escolhe dar visibilidade com a fotografia?}

Ao investigar os processos a que se dava visibilidade, foi possível constatar que existem luzes e sombras nas escolhas feitas no cotidiano da escola. Esta dimensão da análise evidenciou que existem tempos e espaços mais valorizados pelas educadoras em relação à documentação que é construída com fotografia, contudo, percebemos também processos de "invisibilização". A pesquisa demonstrou que alguns ambientes da escola não são utilizados como espaços educativos. Por exemplo, o saguão de entrada, as salas administrativas e o refeitório são invisibilizados e, assim, as interações das crianças nesses espaços não são fotografadas e não há fotografias expostas. Esses espaços invisibilizados também são cenários de aprendizagens das crianças, que não são previstas no currículo da escola, e que acabam não sendo documentadas. Quanto aos tempos, a pesquisa avaliou que existem momentos privilegiados em relação à fotografia. As educadoras documentam com fotografia vivências coletivas ou com seus grupos, que na perspectiva delas possuem mais relevância no contexto dos projetos. 


\section{2) Quem é responsável por fotografar?}

A pesquisa constatou que a responsabilidade por fotografar costuma ser das educadoras, que assumem o papel de educador-investigador, adotando a fotografia como possibilidade de produção de registro e memória do cotidiano, para documentar as vivências da criança na escola. $\mathrm{Na}$ análise, verificamos que as fotos produzidas pelas professoras podem ter abrangência em duas dimensões: a dimensão local e a dimensão global. A nível local, as fotos contemplam a documentação contextualizada, que está relacionada à avaliação dos percursos das crianças. Este tipo de documentação atende ao planejamento das educadoras e contribui com uma avaliação mais holística das crianças. A nível global, as fotos dão visibilidade aos processos da escola como um todo, incidindo em aspectos relativos à qualidade da educação oferecida pela escola ou, em nível mais amplo, às redes de ensino.

\section{3) Que imagem de criança pretende-se comunicar?}

A pesquisa demonstrou que a imagem de criança que se pretende comunicar está relacionada às concepções de criança e infâncias construídas socialmente, que são assimiladas e subjetivadas pelas educadoras. A mídia, em geral, costuma propagar imagens estereotipadas das crianças e, neste viés, a documentação com fotografia pode se constituir como oportunidade para que as estruturas cristalizadas pelos veículos midiáticos sejam rompidas. A investigação também demonstrou que as professoras têm refletido sobre a necessidade de fotografar momentos espontâneos, sem que as crianças precisem fazer poses nem que a foto seja dirigida, controlada. Esta forma de fotografar dá maior liberdade às crianças e, segundo as professoras, propicia que a imagem seja mais próxima à realidade, narrando um percurso mais fiel das aprendizagens documentadas. Esta reflexão parece dar ao registro fotográfico um lugar de destaque, mostrando como o trabalho pedagógico é feito e como as crianças vivenciam a escola.

\section{4) Como e quando as crianças são fotografadas?}

Procuramos saber como e quando as crianças são fotografadas, registrando o indício de que há diferença entre os momentos mais valorizados para a equipe gestora e para as professoras da escola. Em 2018, as educadoras, na posição de gestoras, mostraram maior preocupação em documentar com fotografia as propostas coletivas, de integração entre os grupos, pois eram essas vivências que 
compunham o álbum que constitui a memória da escola como um todo. Já em 2019, quando assumiram os grupos de Pré-A, as professoras passaram a privilegiar as propostas direcionadas, em que as crianças estivessem em um ambiente mais controlado, facilitando o ato de fotografar. Nessas vivências, as professoras acompanham as investigações e hipóteses que as crianças constroem, quando estão em grupos menores ou sozinhas, explorando objetos ou materiais específicos.

\section{5) Como e quando as fotos são publicizadas?}

Analisamos como e quando as fotos são publicizadas e verificamos que a escola compartilha fotos de diferentes maneiras: há exposições nos corredores, nos portfólios das crianças e divulgadas em rede social. Nos dois anos em que a pesquisa se desenvolveu, as educadoras responsáveis por cada grupo organizaram coletâneas pedagógicas individuais com as produções e fotografias das crianças, que foram entregues às famílias no final de cada ano. Nestes artefatos, as fotos foram organizadas de forma a complementar outros registros, como desenhos e produções artísticas das crianças. As demais formas de divulgação das fotos surgiram como uma alternativa para minimizar a distância entre a escola e as famílias, tornando possível que a documentação alcance com mais frequência a comunidade escolar. Nesse sentido, o uso de uma plataforma digital parece ser promissor, para que as escolas consigam maior interação e participação das famílias nos processos educativos.

\section{6) Com quem e para quem se compartilha as fotografias?}

Quanto à sexta questão, verificamos que as famílias possuem centralidade neste processo. As educadoras dizem que tentam se colocar no lugar dos familiares que serão expectadores das fotos para projetarem suas ações. Elas destacam a importância de que as fotos mostrem às famílias que as crianças estão sendo bem cuidadas e que estão tendo uma experiência rica de vivências e aprendizagens na escola. Nesse sentido, a fotografia também se constitui artefato de validação e avaliação do trabalho docente e que, portanto, pode estabelecer uma dualidade: ao mesmo tempo em que pode ser instrumento de valorização da atividade do professor na educação infantil, pode ser dispositivo de controle e vigilância, tanto para familiares quanto para as crianças. 


\section{7) E o fotógrafo, em que oportunidades aparece nas fotos que produz?}

A última questão de pesquisa buscou compreender qual o lugar das professoras/educadoras nas fotos que elas próprias produzem. As respostas revelam aspectos relacionados à exposição das professoras nos registros fotográficos. Elas dizem que sentem vontade de aparecer nas fotos que elas próprias tiram, mas alguns fatores influenciam para que isso não ocorra na maioria dos casos. O primeiro aspecto é em relação à estrutura das escolas, já que os grupos de pré-escola têm apenas uma professora cada, com sobrecarga à professora que precisa planejar, fotografar e avaliar, quase sempre sozinha, as ações pedagógicas. Outro ponto destacado, diz respeito à confiança necessária na equipe de trabalho, que as educadoras dizem ser necessária para que se possa delegar à outra colega a responsabilidade por fotografar seu grupo. Além de domínio técnico, as educadoras consideram importante que toda a equipe esteja envolvida em um processo reflexivo para que se produza fotos com mais qualidade e para que haja uma unidade na documentação que a escola produz.

A análise de conteúdo realizada evidenciou uma lacuna em relação ao tema "Teoria e Prática", que se referia às concepções teóricas e práticas das educadoras sobre documentação pedagógica e fotografia. $\mathrm{Na}$ análise de conteúdo, o código "Teoria e Prática" foi o único que não apareceu em concorrência com nenhuma das demais dimensões de análise, indicando que esse aspecto não pareceu evidente durante a imersão na escola. Com a observação participativa e com os diálogos transversais estabelecidos em entrevistas, além da participação em reuniões de formação, não foi possível identificar quais perspectivas teórico-práticas ancoravam as propostas pedagógicas da escola antes do início da pesquisa.

"Teoria e Prática" é um tema caro à pesquisa-ação, principalmente quando esta modalidade metodológica é aplicada em contextos educativos, pois o propósito é aprimorar a prática pedagógica, através do respaldo teórico da pesquisa científica à práxis. Contudo, reconhece-se que esta lacuna pode ter sido uma falha no planejamento da pesquisa-ação, já que quando a pesquisa iniciou não se deu tanta ênfase à esta questão nas perguntas feitas em entrevista às gestoras. Percebemos as gestoras como profissionais mais habilitadas a falar sobre o embasamento da proposta da escola e contextualizar o processo de elaboração do PPP, ou mesmo, justificar qual era o amparo teórico para as orientações que elas davam às professoras no desenvolvimento dos projetos que 
aconteciam na escola. A partir de 2019, este hiato ficou ainda mais palpável, pelo movimento de adaptação do currículo que a escola vinha fazendo em função da implementação da BNCC. As educadoras enfrentaram dificuldades significativas na organização do planejamento pedagógico, o que pode ter incidido no planejamento dos momentos que elas precisavam fotografar.

Para preencher esta lacuna, estabeleceu-se um diálogo com as educadoras participantes no primeiro semestre de 2020 , durante o período de isolamento social, em decorrência da pandemia de Covid-19. Realizou-se uma conversa virtual através de chamada de vídeo, com a participação de três educadoras que acompanharam todo o percurso de imersão na escola (Andressa, Franciane e Tchéssika). Estas educadoras, hoje, atuam em outras escolas ou instâncias administrativas da rede municipal de ensino de Erechim-RS. O intuito deste "encontro" foi revisitar questões feitas nas primeiras entrevistas, para que fossem identificados possíveis aprimoramentos no pensamento crítico e teórico delas após a experiência de ter participado da pesquisa.

$\mathrm{Na}$ primeira rodada de perguntas, pediu-se que elas falassem como foi participar da pesquisa nos dois momentos: primeiro, atuando na equipe gestora, em 2018 e, depois, como professora de um dos quatro grupos participantes, em 2019. Elas também falaram sobre as mudanças em sua prática com a fotografia, que ocorreu ao longo da pesquisa. Trago para as considerações finais da pesquisa apenas uma fala desta conversa, a fim de preencher a lacuna que se tinha em relação ao embasamento teórico para a elaboração do currículo da escola: ${ }^{66}$

Franciane (coordenadora pedagógica/2018) - Não sei exatamente há quanto tempo ouvimos falar de Reggio Emilia, mas lembro que tínhamos lido alguns livros na escola. No final de 2017, quando fomos elaborar o PPP de 2018, quisemos incluir algo no sentido de levar em conta os interesses da criança, porque dentro das condições que nós tínhamos, talvez fosse possível colocar em prática algumas daquelas ideias. Não digo igual, mas algo próximo. A gente sabe que o trabalho que acontece em Reggio Emilia envolve inúmeros fatores. (...) A ideia nunca foi transformar nossa escola em uma "Reggio", mas ir aos poucos desenvolvendo uma proposta dentro daquilo que nós acreditávamos que seria interessante, que seria produtivo para as crianças, e ir evoluindo aos poucos... O mais legal na nossa escola, é que as ideias foram surgindo e todo mundo abraçou a causa. O grupo tinha como característica a vontade de querer fazer as coisas de um jeito diferente, de mudar, evoluir, e nós vimos na proposta de Reggio Emilia uma inspiração. (...) O que nós precisamos é de um grupo determinado a mudar e isso nós tínhamos.

\footnotetext{
${ }^{66}$ As transcrições das falas mais significativas das educadoras neste encontro estão disponíveis nos
} apêndices deste documento - Apêndice $L$ e Apêndice $M$. 
Nesta fala, percebemos que a proposta de trabalho desenvolvida ao longo da pesquisa foi de continuidade a um pensamento teórico-prático que já vinha se desenvolvendo. A inspiração na abordagem pedagógica de Reggio Emilia parece ter influenciado a dinâmica de reestruturação do currículo da escola e contribuído para a elaboração de propostas centradas nos interesses da criança. Outro ponto relevante na fala da educadora é a importância do trabalho cooperativo na escola, entre as professoras. Nessa perspectiva, foi interessante na dinâmica de conversa de vídeo, perceber que a fala das educadoras passou a ser construída de forma coletiva, muitas vezes utilizando expressões que se referiam à vivência delas dentro do grupo, e não apenas de suas aprendizagens individuais. Com isso, percebemos que a reflexão proporcionada pela pesquisa trouxe um ganho em relação à constituição do fazer pedagógico como construção social e, a documentação pedagógica, como um artefato que tem se construído na coletividade dos contextos educativos.

$\mathrm{Na}$ última sessão da tese, apresento oito histórias que narram o percurso das crianças na experimentação com a fotografia em vivências planejadas pelas professoras a partir da proposta de currículo emergente, e com as reuniões de formação. Conforme fora exposto, a decisão de elaborar as mini-histórias partiu da identificação, em momento posterior à análise de conteúdo, de que havia narrativas possibilitadas pelas fotografias que careciam de maior exploração. No entanto, é necessário reconhecer que pode ter sido uma escolha metodológica tardia. Pois, caso tivesse sido pensada durante a pesquisa-ação, as próprias educadoras poderiam ter assumido esta autoria, o que daria novos dimensionamentos e, consequentemente, maior valorização da voz deste grupo de participantes na pesquisa. Dito isso, reitero que o exercício de elaboração destas histórias, ainda que de forma experimental, foi uma opção metodológica importante, que garantiu à fotografia o status de linguagem completa e dotada de sentidos - o que cumpre com a proposta inicial da tese. A iniciativa aproxima a pedagogia das artes e da estética, conforme vêm fazendo outros campos de estudo há mais tempo. Não obstante, a experiência sugere que pode ser promissor empreender na realização de estudos futuros que se proponham a aprofundar investigações referentes às aprendizagens das crianças nas experimentações com a fotografia e a interpretação de imagens por crianças e professores em contextos educativos. Algumas possibilidades foram lançadas por meio de temas e questionamentos que emergiram... 
Mas afinal, é possível responder a estas questões realizando uma pesquisa?

Encerro esta discussão renovando a indagação que motivou a realização da tese, com a expectativa de que as perguntas que emergiram das mini-histórias sejam exploradas na constituição de novas categorias de análise ou no aprimoramento do escopo documental e narrativo das escolas, em próximas ações, atuações e investigações.

As narrativas construídas com as imagens confirmam a potência da documentação com fotografia e fortalecem a compreensão de que as imagens fotográficas constituem uma linguagem completa, dotada de sentidos e capaz de dialogar diretamente com o sujeito-expectador. Nessas histórias, percebemos que o ambiente para a fotografia não pode ser apressado, pois é preciso permitir que a criança e o educador, na posição quem fotografa, consigam juntos explorar as complexidades do ambiente ou simplesmente desfrutar de momentos partilhados. Entre o visível e o invisível, a documentação funda uma narrativa peculiar, construída na interpretação de sentidos e na atribuição de significados. Reafirmamos, assim, que as crianças são indivíduos com agência e competências necessárias para transformarem as interações que mantêm no meio social e que são capazes de perspectivar, nestes contextos, as mudanças por elas desejadas. 


\section{7 \\ Referências Bibliográficas}

AGENCY BY DESIGN; PROJECT ZERO (Cambridge, MA). Harvard Graduate School of Education/Harvard University. The Framework for Maker-Centered Learning, 2020. Disponível em: http://www.agencybydesign.org/explore-the-framework. Acesso em: 08 maio 2020.

AMARAL, Maria Cristina Fontes. Registros e avaliação na educação infantil: entrecruzando olhares para qualificar as práticas. (Dissertação de Mestrado). Universidade Federal de Juiz de Fora, 2014. Disponível em: <https://repositorio.ufjf.br/jspui/handle/ufjf/794> Acesso em: 06 de jul. de 2018.

ARIÈS, Philippe. História social da criança e da família. 2. ed. Rio da Janeiro: Editora Guanabara, 1981.

ARNDT, Sonja; TESAR, Marek. Early childhood assessment in Aotearoa New Zealand: critical perspectives and fresh openings. Journal of Pedagogy, [S.L.], v. 6, n. 2, p. 71-86, 1 dez. 2015. Walter de Gruyter GmbH. http://dx.doi.org/10.1515/jped-2015-0014.

AUGÉ, Marc. Não-lugares: introdução a uma antropologia da supermodernidade. 9. ed. Campinas, SP: Papirus, 2001. Tradução de: Maria Lúcia Pereira.

BARACHO, Nayara Vicari de Paiva. A documentação na abordagem de Reggio Emilia para a Educação Infantil e suas contribuições para as práticas pedagógicas: um olhar e as possibilidades em um contexto brasileiro. (Dissertação de Mestrado em Educação) Orientação: Dra. Marieta Lúcia Machado Nicolau. FACED, USP. São Paulo, 2011.

BARDIN, Laurence. Análise de conteúdo. Lisboa: Edições 70, 1977.

BATH, Caroline. 'I can't read it; I don't know': young children's participation in the pedagogical documentation of English early childhood education and care settings: young children's participation in the pedagogical documentation. International Journal of Early Years Education, Londres, v. 20, n. 2, p. 190-201, jun. 2012. Informa UK Limited. Disponível em: http://dx.doi.org/10.1080/09669760.2012.715242. Acesso em: 24 jan. 2020.

BARTHES, Roland. A câmara clara: nota sobre a fotografia. Tradução: Júlio Castañon Guimarães. Rio de Janeiro, RJ: Nova Fronteira, 1984. 
BARTHOLOMEU, Fabiana. Uma experiência de formação continuada: o papel do coordenador pedagógico e do registro reflexivo na formação de professores de Educação Infantil. 2016. 116 f. Dissertação (Mestrado em Educação: Formação de Formadores) - Programa de Estudos PósGraduados em Educação: Formação de Formadores, Pontifícia Universidade Católica de São Paulo, São Paulo, 2016. Disponível em: <https://tede2.pucsp.br/handle/handle/19331> Acesso em: 06 de jul. de 2018.

BAUER, Martin W. Análise de Conteúdo Clássica: uma revisão. In: BAUER, Martin W.; GASKELL, George. (Ed.) Pesquisa qualitativa com texto, imagem e som: um manual prático. 7. Ed. Tradução Pedrinho A. Guareschi. Petrópolis: Vozes, 2008. p. 189-217.

BAUER, Martin W.; GASKELL, George. (Ed.) Pesquisa qualitativa com texto, imagem e som: um manual prático. 7. ed. Tradução Pedrinho A. Guareschi. Petrópolis: Vozes, 2008.

BEAUMONT-BATES, Joanne. E-portfolios: Supporting Collaborative Partnerships in an Early Childhood Centre in Aotearoa/New Zealand. New Zealand Journal of Educational Studies, Auckland, v. 52, n. 2, p. 347362, 2017.

BOGDAN, Robert; BIKLEN, Sari. Investigação qualitativa em educação. Portugal: Porto, 1994.

BRANDÃO, Carlos Rodrigues. Participar-pesquisar. In: Brandão, Carlos Rodrigues (org). Repensando a pesquisa participante. 3 ed. São Paulo: Brasiliense, 1998.

BRASIL. Ministério da Educação. Base Nacional Comum Curricular. Brasília: MEC, 2017.

BRASIL. Ministério da Educação. Conselho Nacional de Educação. Câmara de Educação Básica. Diretrizes Curriculares Nacionais Para a Educação Infantil. Brasília: MEC, 2009a.

BRASIL. Ministério da Educação. Conselho Nacional de Educação. Câmara de Educação Básica. Práticas Cotidianas na Educação Infantil: bases para a reflexão sobre as orientações curriculares. Brasília: MEC, 2009b.

BRASIL. Ministério da Educação e do Desporto. Secretaria de Educação Fundamental. Referencial Curricular Nacional para a Educação Infantil /Ministério da Educação e do Desporto, Secretaria de Educação Fundamental. Vol.3. Brasília: MECISEF, 1998.

BUCKINGHAM, David. Crescer na era das mídias eletrônicas. São Paulo, 2000. Editora Loyola. 
BUFFA, Ester. Práticas e fontes de pesquisa em história da educação. In: GATTI JR., Décio e INÁCIO FILHO, Geraldo (orgs.). História da educação em perspectiva. Ensino, pesquisa, produção e novas investigações. Campinas,SP: Autores Associados; Uberlândia, MG: EDUFU, 2005.

CANVA COMPANY PROFILE (Sydney). Craft. 2020. Disponível em: https://craft.co/canva. Acesso em: 12 set. 2020.

CARR, Margaret; LEE, Wendy, Learning stories. Londres: Sage, 2012.

CARR, Margaret. Assessment in early childhood settings: Learning stories. Londres: Sage, 2001.

CAMPOS, Roselane de Fátima; DURLI, Zenilde; CAMPOS, Rosânia. BNCC e privatização da Educação Infantil: impactos na formação de professores. Retratos da Escola, [S.L.], v. 13, n. 25, p. 170-185, 5 ago. 2019. Confederação Nacional dos Trabalhadores em Educação (CNTE). http://dx.doi.org/10.22420/rde.v13i25.962.

CARVALHO, Alice Teles de; MUNIZ, Vanessa Messias; GOMES, Josiane Fernandes; SAMICO, Isabella. Programa de alimentação escolar no município de João Pessoa - PB, Brasil: as merendeiras em foco. Interface - Comunicação, Saúde, Educação, [S.L.], v. 12, n. 27, p. 823-834, dez. 2008. FapUNIFESP (SciELO). http://dx.doi.org/10.1590/s141432832008000400012.

CORBIN, Juliet; STRAUSS, David A.; Basics of Qualitative Research: Grounded Theory Procedures and Techniques. London: SAGE. Publications, 1990.

CORSARO, William. Sociologia da Infância. Porto Alegre: Artmed, 2011.

CORSARO, William. Métodos etnográficos no estudo da cultura de pares e das transições iniciais na vida das crianças: diálogos com William Corsaro. In: MULLER, Fernanda; CARVALHO, Ana Maria Almeida (org). Teoria e prática na pesquisa com crianças. São Paulo: Cortez, 2009.

DAHLBERG, Gunilla. Documentação Pedagógica. In: EDWARDS, Carolyn; GANDINI, Lella; FORMAN, George. (org.). As cem linguagens da criança: a experiência de Reggio Emilia em transformação. v.2. Porto Alegre. Penso, 2016.

DAHLBERG, Gunilla; MOSS, Peter; PENCE, Alan. Qualidade na Educação da Primeira Infância: perspectivas pós-modernas. Porto Alegre: Artmed, 2003.

DEL PRIORE, Mary. (org.) História das crianças no Brasil. São Paulo: Contexto, 2000. 
DELALANDE, Julie. La cour de la récréation. Pour une anthropologie de l'enfance. Rennes: Presses Universitaires de Rennes, 2001. 278 p.

DEMO, Pedro. Metodologia da Investigação em Educação. Curitiba: IBPEX, 2005.

DEWEY, John, 1859-1952. Vida e educação. Tradução de Anísio Teixeira. - 5 ed. - São Paulo: Editora Nacional, 1959. - (coleção atualidades pedagógicas).

DIDI-HUBERMAN, Georges. Quando as imagens tocam o real. In: Revista Pós, v.2, n.4, nov. 2012. p. 204-219. Disponível em: https://www.eba.ufmg.br/revistapos/index.php/pos/article/view/60/62 Acesso em: 07 maio 2018.

DIDI-HUBERMAN, Georges. Diante da imagem: questão colocada aos fins de uma história da arte. Tradução Paulo Neves. São Paulo: Editora 34, 2015.

DIDI-HUBERMAN, Georges. Atlas ou A Gaia ciência inquieta. Série: O olho da

história, n3. Lisboa: KKYM+EAUM, 2013. 315 p.

DIDI-HUBERMAN, Georges. O que vemos, o que nos olha. Tradução de: Paulo Neves. São Paulo: Editora 34, 2010.

DOCUMENTAÇÃO. In: Michaelis On-line: Dicionário Brasileiro da Língua Portuguesa. Editora Melhoramentos Ltda, 2020. Disponível em: https://michaelis.uol.com.br/moderno-portugues/busca/portuguesbrasileiro/documenta\%C3\%A7\%C3\%A3o/. Acesso em: 05 mar. 2020.

EDWARDS, Carolyn; GANDINI, Lella; FORMAN, George. (org.). As cem linguagens da criança: a experiência de Reggio Emilia em transformação. V.2. Porto Alegre. Penso, 2016.

EMEI D. JOÃO A. HOFFMANN (Erechim). Secretaria Municipal de Educação de Erechim. Postagem: "Exposição de fotos na escola". Erechim, 12 dez. 2018. Elaborada pela Equipe Diretiva da Escola. Facebook: @emeidomjoaoaloisiohoffmann. Disponível em: https://www.facebook.com/emeidomjoaoaloisiohoffmann. Acesso em: 20 dez. 2018.

EMILSON, Anette; PRAMLING-SAMUELSSON, Ingrid. Pramling. Documentation and communication in Swedish preschools. Early Years, $n$. 34, v. 2, 2014, p. 175-187. Disponível em: https ://doi.org/10.1080/09575 146.2014.88066 4. Acesso em: 03 jul. 2020. 
FELCHER, Carla D. O; FERREIRA, André L. A.; FOLMER, Vanderlei. Da pesquisa-ação à pesquisa participante: discussões a partir de uma investigação desenvolvida no Facebook. Experiências em Ensino de Ciência, v.12, n. 7. p. 01-18, 2017. Disponível em: https://if.ufmt.br/eenci/artigos/Artigo_ID419/v12_n7_a2017.pdf Acesso em: 20 nov. 2020.

FERNANDES, Ana Gabriela de Souza; FONSECA, Alexandre Brasil Carvalho da; SILVA, Adilson Aderito da. Alimentação escolar como espaço para educação em saúde. Ciênc. saúde coletiva, Rio de Janeiro, v. 19, n. 1, p. 39-48, Jan. 2014. Disponível em: http://www.scielo.br/scielo.php?script=sci_arttext\&pid=S1413-

81232014000100039\&Ing=en\&nrm=iso. Acesso em: 02 Set. 2020. https://doi.org/10.1590/1413-81232014191.1711.

FERRARESI, Elaine. Registros professorais na primeira infância: a escrita, as imagens e a oralidade como dispositivos de subjetivação e reflexividade.' 01/04/2015 165 f. Mestrado em Educação Instituição de Ensino: Centro Universitário Salesiano de São Paulo, São Paulo Biblioteca Depositária: Centro Universitário Salesiano de São Paulo - Unidade Americana, 2015.

FLUSSER, Vilém. Filosofia da caixa preta: ensaios para uma futura filosofia da fotografia. Rio de Janeiro, RJ: Relume Dumará, 2002.

FOCHI, Paulo Sergio. A documentação pedagógica como estratégia para a construção do conhecimento praxiológico: 0 caso do Observatório da Cultura Infantil - OBECI. 346 p. Tese (Doutorado Programa de Pós-Graduação Formação, Currículo e Práticas Pedagógicas). Faculdade de Educação, Universidade de São Paulo, 2019.

FOCHI, Paulo Sergio. Afinal, o que os bebês fazem no berçário?: comunicação, autonomia e saber-fazer de bebês em um contexto de vida coletiva. Porto Alegre: Penso Editora, 2015.

FOCHI, Paulo Sergio. "Mas os bebês fazem o que no berçário, heim?”: documentando ações de comunicação, autonomia e saber-fazer de cianças de 6 a 14 meses em contextos de vida coletiva. 172 f. Dissertação (Mestrado em Educação) - Programa de Pós-Graduação em Educação. Faculdade de Educação. Universidade Federal do Rio Grande do Sul, Porto Alegre, 2013.

FORMOSINHO, João; OLIVEIRA-FORMOSINHO, Júlia. Pedagogias transmissivas e pedagogias participativas nas escolas. In: OLIVEIRAFORMOSINHO, Júlia; PASCAL, Christine (org.). Documentação pedagógica e avaliação na educação infantil: um caminho para a transformação. Porto Alegre: Penso, 2019. Cap. 2. p. 03-25. Tradução: Alexandre Salvaterra; revisão técnica: Júlia Oliveira-Formosinho, Mônica Appezzato Pinazza, Paulo Fochi. 
FREIRE, Madalena. Observação, registro, reflexão: Instrumentos metodológicos I. São Paulo: Espaço Pedagógico, 1995.

FREIRE, Madalena. A paixão de conhecer o mundo. 7 ed. Editora Paz e Terra. Rio de Janeiro, 1989.

FU, Victoria R.; GOLDHABER, Jeanne; TEGANO, Deborah W.; STREMMEL, Andrew. Recasting the Reggio Emilia approach: Defining ourselves through visual images and the multiple voices of collaborative research. Paper presented at the annual conference of the National Association for the Education of Young Children, Atlanta, GA, 2000.

FUNDAÇÃO MARIA CECÍLIA SOUTO VIDIGAL; FUNDAÇÃO CARLOS CHAGAS. Políticas internacionais para a educação infantil. FMCSV:: São Paulo, 2018. Disponível em: https://fmcsv.microsoftcrmportals.com/ptBR/biblioteca/Politicas_internacionais_para_a_Educacao_Infantil/ Acesso em: 15 jun. 2020.

GAMBETTI, Amelia; GANDINI, Lella. Introdução. In: REGGIO CHILDREN. As cem linguagens em mini-histórias: contadas por professores e crianças de Reggio Emilia. (E-pub - Kindle Edition) Porto Alegre: Penso, 2020. Tradução de: Guilherme Adami; revisão técnica: Ana Teresa Gavião A. M. Mariotti, Aparecida de Fátima Bosco Benevuto.

GANDINI, Lella; GOLDHABER, Jeanne. Duas reflexões sobre a documentação. In: Gandini, Lella; Edwards, Carolyn. (Org.). Bambini: a abordagem italiana à educação infantil. Porto Alegre: Artmed, 2002, p. 150169.

GOMES, Jerusa Vieira. Socialização primária: tarefa familiar? Cadernos de Pesquisa, n. 91, p. 54-91, nov. 1994.

GONÇALVES, Beatriz Moreira de Azevedo Porto; Duarte, Rosália Maria. (Orientadora) - Atlas do Audiovisual Escolar, territórios da Mostra Geração: Rio de Janeiro, 2000 a 2014. Tese de Doutorado (Departamento de Educação, Pontifícia Universidade Católica do Rio de Janeiro). Rio de Janeiro, 2019. 183 p.

GONTIJO, Flávia Lamounier. Documentação pedagógica como instrumento de reflexão e produção docente na educação infantil. Paidéia r. do cur. de ped. da Fac. de Ci. Hum., Soc. e da Saú., Univ. Fumec Belo Horizonte, Ano 8, n.10, p. 119-134, jan./jun. 2011. Disponível em: <http://www.fumec.br/revistas/paideia/article/view/1303>. Acesso em: 15 de nov. de 2017.

GRIESHABER, Susan; HATCH, J. Amos. Pedagogical Documentation as an Effect of Globalization. Journal of Curriculum Theorizing, v.19, n. 1, 2003, p. 89-102. 
HADDAD, Lenira. Prefácio. In: OSTETTO, Luciana Esmeralda (org.). Registros na educação infantil: Pesquisa e prática pedagógica Campinas, SP: Papirus, 2017.

HALL, Stuart. Da Diáspora: Identidades e Mediações Culturais. Liv Sovik (org); Trad. Adelaine La Guardia Resende. Belo Horizonte: Editora UFMG; Brasília: Representação da Unesco no Brasil, 2003.

HORN, Claudia Ines. Documentação pedagógica: a produção da criança protagonista e do professor designer. 24/02/2017 267 f. Doutorado em EDUCAÇÃO Instituição de Ensino: Universidade do Vale do Rio Dos Sinos, São Leopoldo Biblioteca Depositária UNISINOS, 2017. Disponível em: http://www.unisinos.br/biblioteca/ Acesso em: 06 de jul. de 2018.

HOYUELOS, Alfredo. La estética en el pensamento y obra pedagógica de Loris Malaguzzi. Barcelona: Octaedro, 2006.

HOYUELOS, Alfredo. La complehidad en el pensamento y obra pedagógica de Loris Malaguzzi. Mexico: Multimedios, 2003.

IBÁÑEZ, Juan José Fernández. Didáctica de la imagen: educación de la sensibilidade visual. Nivel 1 / Deusto: Ttarttalo. Bilbao - Espanha, 1986.

KAWADA, Valdejane Tavares. A documentação pedagógica como mediação à construção do conhecimento escolar na educação infantil Manaus. 94 f. Mestrado em Educação Instituição de Ensino: Universidade Federal do Amazonas, Manaus Biblioteca Depositária: Biblioteca Da Ufam Setor Norte, 2016.

KOSSOY, Boris. Fotografia \& História. São Paulo: Ateliê Editorial, 2001.

KUHLMANN JR., Moyses. Infância e Educação Infantil: uma abordagem histórica. Porto Alegre: Mediação, 1998.

LAZARI, Cleuza Brito da Silva. Avaliação na Educação Infantil: concepção de professoras do município de Cáceres expressa nos relatórios descritivos de avaliação. 101 f. Mestrado em Educação Instituição de Ensino: Universidade do Estado de Mato Grosso, Cáceres Biblioteca Depositária: Biblioteca Regional de Cáceres, 2013.

LICHY, Juliana Guerreiro. A documentação pedagógica e o trabalho com bebês: estudo de caso em uma creche universitária. (Dissertação de Mestrado em Educação) Instituição de Ensino: Universidade de São Paulo. Biblioteca Depositária: FEUSP, 2014.

LINO, Dalila Maria Brito da Cunha. A qualidade do contexto na educação de infância perspectivada através da escolha e do envolvimento. Nuances: estudos sobre Educação, Presidente Prudente-SP, v. 25, n. 3, p. 137-154, set./dez.

2014

Disponível

em: 
http://dx.doi.org/10.14572/nuances.v25i3.3201 Acesso em: 11 dez. 2020.

LOPES, Jader Janer Moreira. Geografia das Crianças, Geografias das Infâncias: as contribuições da Geografia para os estudos das crianças e suas infâncias. Contexto \& Educação. Editora Unijuí. Ano 23, no 79 Jan./Jun. 2008, p. 65-82.

LOPES, Jader Janer Moreira. Crianças e jovens em movimento: histórias e identidades no espaço brasileiro. In: VASCONCELLOS, Vera M. R. de. Educação da Infância: História e Política. Rio de Janeiro: DP\&A Editora. 2005.

LOPES, Alice Casemiro; MACEDO, Elisabeth (org.) Currículo: debates contemporâneos. São Paulo: Cortez, 2003.

LOPES, Jader Janer Moreira. Então somos mudantes: espaço, lugar e identidades em crianças migrantes. Tese (Doutorado em Educação). Orientação: Vera Maria Ramos de Vasconcellos. Programa de PósGraduação em Educação. Universidade Federal Fluminense, Niterói, 2003.

LOURO, Guacira Lopes. Gênero, sexualidade e educação: uma perspectiva pós-estruturalista. Petrópolis, RJ.: Vozes, 1997.

MACHADO, Ilze Maria Coelho. Organização do trabalho pedagógico de professoras da educação infantil: evidências nos registros escritos. (Dissertação de Mestrado) - PUCPR. Curitiba, 2009. Disponível em: http://www.biblioteca.pucpr.br/tede/tde_busca/arquivo.php?codArquivo=13 97 Acesso em: 06 de jul. de 2018.

MAGALHÃES, Lucinha; MARINCEK, Vânia. Instrumentos de registro da reflexão do professor. In: CAVALCANTI, Zélia (coord.). A história de uma classe. Porto Alegre: Artmed, 1995.

MAGNUSSON, Lena O. Photographic agency and agency of photographs: Three-year-olds and digital cameras. Australasian Journal of Early Childhood, v. 43, n.3, Austrália, Setembro de 2018. p. 34-42. Disponível em: https://doi.org/10.23965/AJEC.43.3.04 Acesso em: 17 nov. 2020.

MAKING LEARNING VISIBLE; PROJECT ZERO (Cambridge, MA). Harvard Graduate School of Education/Harvard University. Creating a Culture of Critique. In: Understanding, Documenting and Suporting Individual ang Group Learning: documenting examples, 2006. Disponível em: http://www.pz.harvard.edu/projects/making-learning-visible. Acesso em: 08 maio 2020.

MAKING LEARNING VISIBLE; PROJECT ZERO (Cambridge, MA). Harvard Graduate School of Education/Harvard University. Making Every Voice Heard. In: Understanding, Documenting and Suporting Individual ang Group Learning: documenting examples, 2006. Disponível em: 
http://www.pz.harvard.edu/projects/making-learning-visible. Acesso em: 08 maio 2020.

MAKING LEARNING VISIBLE; PROJECT ZERO (Cambridge, MA). Harvard Graduate School of Education/Harvard University. Listening: the heart of what documentation really is. In: Understanding, Documenting and Suporting Individual ang Group Learning: documenting examples, 2006. Disponível em: http://www.pz.harvard.edu/projects/making-learning-visible. Acesso em: 08 maio 2020.

MAKING LEARNING VISIBLE; PROJECT ZERO (Cambridge, MA). Harvard Graduate School of Education/Harvard University. Documentation: When Does It Make Learning Visible? In: Understanding, Documenting and Suporting Individual ang Group Learning, 2005. Disponível em: http://www.pz.harvard.edu/projects/making-learning-visible. Acesso em: 08 maio 2020.

MALAGUZZI, Loris. A criança é feita de cem. (Poesia) In: EDWARDS, Carolyn; GANDINI, Lella; FORMAN, George. (org.). As cem linguagens da criança: a experiência de Reggio Emilia em transformação. V.2. Porto Alegre. Penso, 2016.

MALAGUZZI, Loris. Your Image of the Child: Where Teaching Begins. Child Care Information Exchange, Lincoln, n. 3, p. 52-56, fev. 1994. Bimensal. Comentários traduzidos e adaptados por Baji Rankin, Leslie Morrow e Lella Gandini de um seminário apresentado pelo Professor Loris Malaguzzi em Reggio Emilia, Itália, junho de 1993.

MALAVASI, Laura; ZOCCATELLI, Barbara. Documentar os projetos nos serviços educativos. 4. ed. Lisboa: Apei - Associação de Profissionais de Educação de Infância, 2019. 160 f.

MARQUES, Amanda Cristina Teagno Lopes. A construção de práticas de registro e documentação no cotidiano do trabalho pedagógico da educação infantil. 384 f. Doutorado em EDUCAÇÃO Instituição de Ensino: UNIVERSIDADE DE SÃO PAULO, São Paulo Biblioteca Depositária: FEUSP. Disponível

http://www.teses.usp.br/teses/disponiveis/48/48134/tde-07042011141501/ Acesso em: 23 de jun. de 2018.

MEDRADO, Juliana Basilio. A prática do registro da rotina de uma turma de Educação Infantil e os sentidos e significados atribuídos pelas crianças e sua professora. Dissertação (Mestrado em Educação: Conhecimento e Inclusão Social) - Universidade Federal de Minas Gerais. Belo Horizonte, 2014. Disponível em: <http://hdl.handle.net/1843/BUOS9UVMLP> Acesso em: 06 de jul. de 2018. 
MENDONÇA, Cristina Nogueira de. A documentação pedagógica como processo de investigação e reflexão na educação infantil. 2009. $132 \mathrm{f}$. Tese (doutorado) - Universidade Estadual Paulista, Faculdade de Filosofia e Ciências, 2009.

MERLI, Angélica de Almeida. $O$ registro como instrumento de reflexão na formação do docente: pesquisa-intervenção em escola municipal de educação infantil. (Dissertação de Mestrado - Programa de Mestrado em Gestão e Práticas Educacionais) Universidade Nove de Julho. São Paulo, 2015.

MINISTÉRIO DA EDUCAÇÃO. Secretaria de Educação Básica. Documentação pedagógica: Textos complementares. Caderno 3. Brasília: MEC/UNESCO, 2018. Organização: Paulo Fochi.

MINISTÉRIO DA INSTRUÇÃO, DA UNIVERSIDADE E DA PESQUISA ITÁLIA. Indicações nacionais para o currículo da escola da infância e do primeiro ciclo de instrução (2012). In: FINCO, Daniela; BARBOSA, Maria Carmen S.; FARIA, Ana Lúcia G. de. (Orgs.) Campos de experiências na escola da infância: contribuições italianas para inventar um currículo de educação infantil brasileiro. Campinas, SP: Edições Leitura Crítica, 2015. p. $15-184$.

MITCHELL, Linda. Assessment and pedagogical documentation. In: MITCHELL, Linda. (Ed.). Democratic policies and practices in early childhood education: An Aotearoa New Zeland Case Study. 1. ed. Springer: Singapura, 2018. p. 87-107.

MONTESSORI, Maria. The Montessori Method (E-book - Kindle Edition). Estados Unidos da América: Editora Cosimo Cassics, 2006.

MORAN, Mary Jane. Indagine collaborativa e uso della fotografia come metodo visuale: un esempio da un programma americano di formazione degli insegnanti. In: BOVE, C. M. (ed.). Ricerca educativa e formazione. Contaminazioni metodologiche. Milão: Franco Angeli, 2009, p. 247-271.

MORAN, Mary Jane; TEGANO, Deborah W.. Moving toward Visual Literacy: photography as a language of teacher inquiry. Early Childhood Research \& Practice: ECRP, Illinois, v. 7, n. 1, Spring, 2005. Disponível em: https://ecrp.illinois.edu/v7n1/moran.html. Acesso em: 11 fev. 2020.

MOREIRA, Juliana Corrêa. Avaliação na educação infantil: a documentação pedagógica e as práticas docentes no contexto dos direitos das crianças. Dissertação (Mestrado) - Universidade Federal de Santa Maria, Centro de Educação, Programa de Pós-graduação em Educação, RS, 2015.

MORIN, Edgar. O Cinema ou o Homem Imaginário. São Paulo: Relógio d’Água Editores, 1997. 
MÜLLER, Fernanda. Infâncias nas vozes das crianças: culturas infantis, trabalho e resistência. Educ. Soc., Campinas, vol. 27, n. 95, p. 553-573, maio/ago. 2006.

NEW ZEALAND NOW. Preschool care and education. Nova Zelândia: Ministry of Business, Innovation \& Employment, 2020. Disponível em: https://www.newzealandnow.govt.nz/living-in-nz/education/childcarepreschool Acesso em: 14 jul. 2020.

OCDE. Starting Strong IV: Monitoring Quality in Early Childhood Education and Care. OECD Publishing: Paris, 2015.

O COMEÇO DA VIDA, Série. Direção de Estela Renner. São Paulo: Maria Farinha Filmes, 2016. 6 episódios.

OLIVEIRA-FORMOSINHO, Júlia; PASCAL, Christine. (org.) Documentação pedagógica e avaliação na educação infantil: um caminho para transformação. Tradução: Alexandre Salvaterra; revisão técnica: Júlia Oliveira-Formosinho, Mônica Appezzato Pinazza, Paulo Fochi. Porto Alegre: Penso, 2019.

OLIVEIRA-FORMOSINHO, Júlia; LINO, Dalila Maria Brito da Cunha. Os papéis das educadoras: as perspectivas das crianças. Educ. Foco, Juiz de Fora, v. 13, n. 2, p. 9-29, fev. 2009.

OLIVEIRA-FORMOSINHO, Júlia. KISHIMOTO, Tizuko Morchida. Formação em contexto: uma estratégia de integração. São Paulo: Pioneira Thomson Learning, 2002.

OLIVEIRA-FORMOSINHO, Júlia (org.). A supervisão na formação de professores: da sala à escola. 7. ed. Porto: Porto Editora, 2002.

OLIVEIRA-FORMOSINHO, Júlia; FORMOSINHO, João. Pedagogia-emparticipação: em busca de uma práxis holística. In: OLIVEIRAFORMOSINHO, Júlia; PASCAL, Christine (org.). Documentação pedagógica e avaliação na educação infantil: um caminho para a transformação. Porto Alegre: Penso, 2019. Cap. 2. p. 26-58. Tradução: Alexandre Salvaterra; revisão técnica: Júlia Oliveira-Formosinho, Mônica Appezzato Pinazza, Paulo Fochi.

OLIVEIRA-FORMOSINHO, Júlia; FORMOSINHO, João (org.). Associação Criança: um contexto de formação em contexto. Braga: Livraria Minho, 2001.

ONG PPS/ HEEMANN, Jeniffer; CAIUBY, Paola. O que faz um espaço público ser bem sucedido? 201-. Disponível em: <http://www.placemaking.org.br/home/o-que-faz-um-espaco-publico-serbem-sucedido/>. Acesso em: 16 maio 2020. 
OSTETTO, Luciana E. No tecido da documentação, memória, identidade e beleza. p. 19-55. In: OSTETTO, Luciana Esmeralda (org.). Registros na educação infantil: Pesquisa e prática pedagógica - Campinas, SP: Papirus, 2017.

OSTETTO, Luciana E. (Org.) Educação infantil: saberes e fazeres da formação de professores. Campinas: Papirus, 2008. (p.13-32).

PARENTE, Maria Cristina Cristo. Avaliação na educação de infância: itinerários de uma viagem de educadores de infância na formação inicial. Interacções: ESE|IPSantarém, Santarém (Portugal), v. 10, n. 32, p. 168182, 2014.

PARENTE, Maria Cristina Cristo. A construção de práticas alternativas de avaliação na Pedagogia de Infância: sete jornadas de aprendizagem. 2004. 392 f. Tese (Doutorado) - Curso de Estudos da Criança, Instituto de Educação, Universidade do Minho, Braga, 2004.

PARENTE, Maria Cristina Cristo. Observação: Um percurso de formação, prática e reflexão. In: OLIVEIRA-FORMOSINHO, Júlia (org.). A supervisão na formação de professores: da sala à escola. 7. ed. Porto: Porto Editora, 2002.

PASCAL, Christine; BERTRAM, Tony. Listening to young citizens: The struggle to make real a participatory paradigm in research with young children. European early childhood education research journal, Londres, v. 17, n. 2, p. 249-262, 2009.

PICHER, Mary Elizabeth. A Cognitive Work Analysis of a Pedagogical Documentation Technology in Ontario's Kindergarten Program. 2019. 276 f. Tese (Doutorado) - Curso de Philosophy Applied Psychology and Human Development, Ontario Institute for Studies in Education, University of Toronto, Ontário, 2019.

PROJECT ZERO, REGGIO CHILDREN. Tornando a aprendizagem visível: crianças que aprendem individualmente e em grupo. 1.ed. Phorte Editora: São Paulo, 2014.

QVORTRUP, Jens. A infância na Europa: novo campo de pesquisa social. CEDIC, Insituto de Estudos da Criança. Braga: Universidade do Minho, 1999.

REGGIO CHILDREN. As cem linguagens em mini-histórias: contadas por professores e crianças de Reggio Emilia. (E-pub - Kindle Edition) Porto Alegre: Penso, 2020. Tradução de: Guilherme Adami; revisão técnica: Ana Teresa Gavião A. M. Mariotti, Aparecida de Fátima Bosco Benevuto. 
RAMOS, Rafaela de Morais. Planejamento, registro e avaliação: instrumentos que ressignificam a prática docente na Educação Infantil. Dissertação (Mestrado Profissional) Programa de Pós-graduação em Ensino na Educação Básica. Universidade Federal de Goiás. Goiânia, 2016.

RINALDI, Carla. Diálogos com Reggio Emilia: escutar, investigar, aprender. São Paulo: Paz e Terra, 2017.

RINTAKORPI, Kati. Documenting with early childhood education teachers: pedagogical documentation as a tool for developing early childhood pedagogy and practises. Early Years, [S.L.], v. 36, n. 4, p. 399-412, 11 abr. 2016. Informa UK Limited. http://dx.doi.org/10.1080/09575146.2016.1145628. Acesso em: 17 jan. 2020.

RIZZINI, Irene. O século perdido: Raízes históricas das Políticas Públicas para a Infância no Brasil. 2. ed. São Paulo: Cortez, 2007.

RODRIGUES, José Paz. Rosa e Carolina Agazzi e o seu jardim de infância - Pequenos documentários. PGL.gal (Portal da Língua Galega). Ponte Vedra-ES, 2018. Disponível em: https://pgl.gal/rosa-carolina-agazzijardim-infancia/ Acesso em: 15 jun. 2020.

SALDAÑA, Johnny. An introduction to codes and coding. Arizona: Arizona State University, 2009.

SARMENTO, Manuel Jacinto; PINTO, Manuel. As crianças e a infância: definindo conceitos, delimitando o campo. In: SARMENTO, Manuel Jacinto; PINTO, Manuel. As Crianças: contextos e identidades. Braga: Centro de Estudos da Criança/ Universidade do Minho, 1997.

SARMENTO, Manuel; GOUVEA, Maria Cristina S. Estudos de Infância: Educação e Práticas Sociais. Rio de Janeiro: Vozes, 2008.

SCOTT, Joan Wallach. Prefácio a Gender and Politics of History. Cadernos Pagu, Campinas, SP, n. 3, p. 11-27, 2007. Disponível em: https://periodicos.sbu.unicamp.br/ojs/index.php/cadpagu/article/view/1721. Acesso em: 29 jan. 2019.

SCOTT, Joan Wallach. Entrevista com Joan Wallach Scott. Revista Estudos Femininos, Florianópolis, v. 6, n. 1, 1998. Entrevistadoras: Miriam Pillar Grossi,Maria Luiza Heilborn, Carmen Rial.

SCOTT, Joan Wallach. Gênero: uma categoria útil de análise histórica. Educação \& Realidade, Porto Alegre, v. 20, n. 2, p. 71-99, jul./dez. 1995. 
SIMIANO, Luciane Pandini. Colecionando pequenos encantamentos... a documentação pedagógica como uma narrativa peculiar para e com crianças bem pequenas. 134 f. Doutorado em Educação Instituição de Ensino: Universidade Federal Do Rio Grande Do Sul, Porto Alegre: Biblioteca Depositária Central da UFRGS, 2015.

SILVA, Krisley Pereira da. Cada click é um registro: o uso da fotografia na documentação pedagógica. (Trabalho de Conclusão de Curso de Especialização em Educação Infantil) Orientação: Dra. Fabiana de Amorim Marcello. UFRGS. Porto Alegre, 2016.

SILVA, Tomaz Tadeu da. Documentos de Identidade: uma introdução às teorias do currículo. Belo Horizonte: Autêntica, 2005.

SOARES, Leandro Queiroz; FERREIRA, Mário César. Pesquisa participante como opção metodológia para investigação de práticas de assédio moral no trabalho. Rev. Psicol., Organ. Trab., Florianópolis , v. 6, n. 2, p. 85-109, dez. 2006. Disponível em http://pepsic.bvsalud.org/scielo.php?script=sci_arttext\&pid=S1984$66572006000200005 \& \mathrm{lng}=$ pt\&nrm=iso. Acesso em: 11 nov. 2020.

SOARES, Natália F.; SARMENTO, Manuel J.; TOMÁS, Catarina A.. Investigação da infância e crianças como investigadoras: metodologias participativas dos mundos sociais das crianças. Nuances: UNESP, Presidente Prudente, v. 12, n. 13, p. 50-64, 2005.

SONTAG, Susan. Sobre fotografia. São Paulo: Cia das Letras, 2004. Tradução de: Rubens Figueiredo.

SOUZA FILHO, Marcilio Lira de. Relações entre aprendizagem e desenvolvimento em Piaget e em Vygotsky: dicotomia ou compatibilidade? Revista Diálogo Educacional, Curitiba, v. 8, n. 23, p. 265-275, abr. 2008.

SPAGGIARI, Sergio. Mini-histórias. In: REGGIO CHILDREN. As cem linguagens em mini-histórias: contadas por professores e crianças de Reggio Emilia. (E-pub - Kindle Edition) Porto Alegre: Penso, 2020. Tradução de: Guilherme Adami; revisão técnica de: Ana Teresa Gavião A. M. Mariotti, Aparecida de Fátima Bosco Benevuto.

STEINBERG, Shirley R., KINCHELOE, Joel L. (org.). Cultura infantil: a construção corporativa da infância. Tradução de George Eduardo Japiassú Bricio. Rio de Janeiro: Civilização Brasileira, 2001, 415p.

THIOLLENT, Michel. Metodologia da pesquisa-ação. 18. ed. São Paulo: Cortez, 2011. 108 p. (Coleção Temas básicos da pesquisa-ação).

TODOS PELA EDUCAÇÃO. Anuário brasileiro da Educação Básica 2019. Editora Moderna: São Paulo, 2019. 
TREVISAN, Rita. Evolução dos documentos: o que diferencia a BNCC do DCNEI e do RCNEI?. In: Nova Escola (São Paulo) (org.). BNCC na prática: tudo que você precisa saber sobre educação infantil. [São Paulo]: Nova Escola, 2018. Cap. 3. p. 16-19.

TRIPP, David. Pesquisa-ação: uma introdução metodológica. Educação e Pesquisa, São Paulo, v. 31, n. 3, p. 443-466, set./dez. 2005 Disponível em: http://www.scielo.br/pdf/ep/v31n3/a09v31n3.pdf. Acesso em: 11 nov. 2020.

UNICEF, Comité Português para a. (ed.) Convenção sobre os Direitos da Criança e Protocolos Facultativos. Edição revista. UNICEF: Portugal, 2019. $80 \quad$ p. $\quad$ Disponível em: https://www.unicef.pt/media/2766/unicef_convenc-a-

o_dos_direitos_da_crianca.pdf Acesso em: 27 maio 2020.

VASCONCELLOS, Vera Maria Ramos de. Educação da infância: história e política. Rio de Janeiro: DP\&A Editora, 2005.

VECCHI, Vea. Arte e criatividade em Reggio Emilia: explorando o papel e a potencialidade do ateliê na educação da primeira infância. Phorte Editora, 2017.

VECCHI, Vea. Estética y aprendizaje (Prólogo) In: HOYUELOS, Alfredo. La estética en el pensamiento y obra pedagógica de Loris Malaguzzi. Barcelona: Octaedro, 2006.

VENÂNCIO, Renato P. Famílias abandonadas - Assistência à criança das camadas populares no Rio de Janeiro e em Salvador - séculos XVIII e XIX. Campinas: Papirus, 1999.

VENÂNCIO, Renato P.; MARCÍLIO, Maria Luiza. História Social da criança abandonada. Rev. bras. Hist., São Paulo, v. 19, n. 37, p. 313-316, set. 1999.

Disponível em:

http://www.scielo.br/scielo.php?script=sci_arttext\&pid=S0102-

$01881999000100014 \&$ Ing=pt\&nrm=iso. Acessos em: 28 maio 2020. https://doi.org/10.1590/S0102-01881999000100014.

VIEIRA, Flaviana Rodrigues. A formação de professoras em uma creche universitária: o papel da documentação no processo formativo. (Dissertação de Mestrado em Educação) Instituição de Ensino: Universidade de São Paulo, São Paulo. Biblioteca Depositária: FEUSP, 2013.

VIGOTSKI, Lev S. Imaginação e criação na infância: ensaio psicológico. São Paulo: Ática, 2009. 134 p. Apresentação e comentários de: Ana Luiza Smolka. Tradução de: Zoia Prestes. 
VISIBLE THINKING; PROJECT ZERO (Cambridge, MA). Harvard Graduate School of Education/Harvard University. Resources, 2020. Disponível em: http://www.pz.harvard.edu/projects/visible-thinking. Acesso em: 08 maio 2020.

WARSCHAUER, C. Nossas escritas na escola e as escritas da escola em nós. E.PSI.B.A Psicopedagogia (Revista da Escuela Psicopedagógica de Buenos Aires), n. 5. Buenos Aires, 1997. Disponível em: https://331e03ee-3c3b-415f-be8dd48a2328167.filesusr.com/ugd/603c36_d359770395ce48ae9c451749453 be641.pdf. Acesso em: 20 maio 2020. 


\section{Apêndice A - Consentimento informado | Crianças}

TERMO DE ASSENTIMENTO LIVRE E ESCLARECIDO

OLÁ, CRIANÇA! SABIA QUE VOCÊ É MUITO
IMPORTANTE? E, POR ISSO, QUERO LHE FAZER
UM IMPORTANTE CONVITE.
VOCÊ GOSTARIA DE PARTICIPAR DE UMA
PESQUISA?

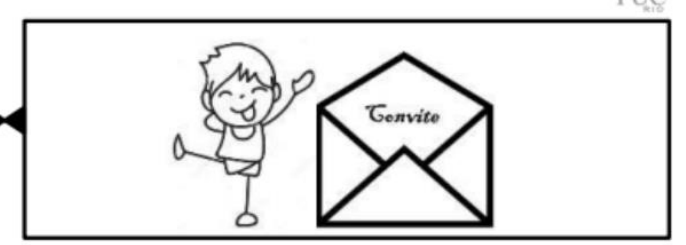

SOU PESQUISADORA DA PUC-RIO, QUE FICA LÁ NO RIO DE JANEIRO.

ALGUMAS PESSOAS DIZEM QUE É COMO UMA "ESCOLA DE GENTE GRANDE".

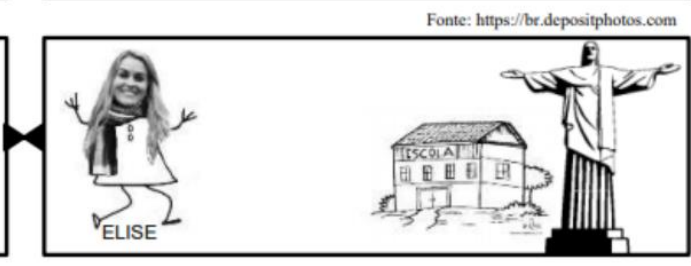

NA PESQUISA, PRECISO FOTOGRAFAR DIFERENTES MOMENTOS EM QUE VOCÊ ESTIVER NA ESCOLA, SOZINHO(A) OU COM SEUS AMIGOS.

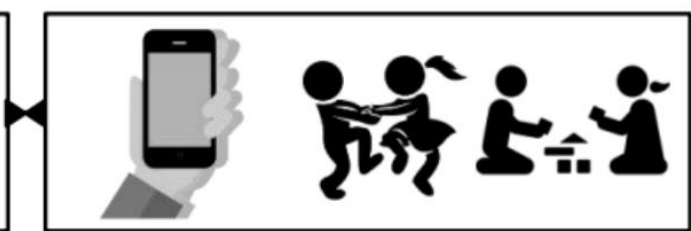

DURANTE A PESQUISA VOCÉ PODE SE SENTIR INCOMODADO (A), COM MEDO OU COM VERGONHA. SE ISSO ACONTECER, É SÓ CHAMAR A MIM OU A SUA PROFESSORA.

VAMOS ENTENDER SE VOCÊ NĀO QUISER MAIS PARTICIPAR.

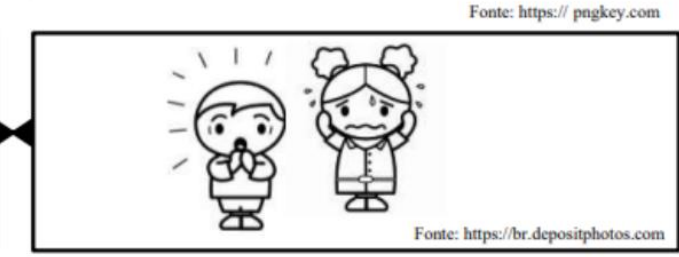

MAS SE ACEITAR PARTICIPAR, VOCÊ ESTARÁ AJUDANDO OUTRAS CRIANÇAS, POIS ACREDITAMOS QUE FAZER ATIVIDADES COM FOTOGRAFIA NA ESCOLA É SENSACIONAL,

ESTIMULA A CRIATIVIDADE E NOS AJUDA A

GUARDAR PARA SEMPRE OS MOMENTOS

VIVIDOS. MAIS GENTE PRECISA SABER DISSO!

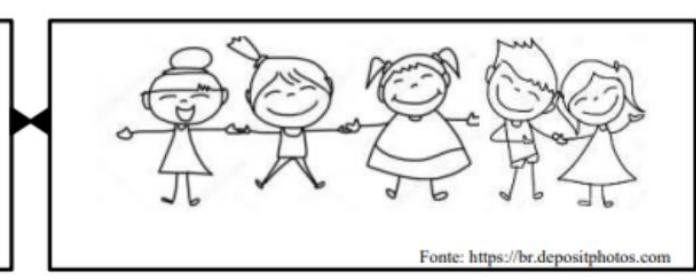

DECLARAÇÃO DE ASSENTIMENTO

MEU NOME É
( ) SIM. EU ACEITO PARTICIPAR DA PESQUISA.
(3) ( ) NÃO. EU NÃO QUERO PARTICIPAR DA PESQUISA. 


\section{Apêndice B - Termo de Consentimento Livre e Esclarecido | Responsáveis pelas crianças}

TERMO DE CONSENTIMENTO LIVRE E ESCLARECIDO

A criança pela qual você é responsável está sendo convidada a participar da pesquisa intitulada "FOTOGRAFIA E DOCUMENTAÇÃO PEDAGÓGICA: DESCREVER, NARRAR E DAR SENTIDO ÀS APRENDIZAGENS EDUCAÇÃO INFANTIL", cujo objetivo é descrever, analisar e compreender o papel que pode ser desempenhado pela fotografia na produção de documentação pedagógica na educação infantil. A finalidade deste trabalho é contribuir para a expansão das reflexões e/ou ações nesta área do conhecimento, em defesa de uma prática pedagógica focada na criança e em suas especificidades, tendo a fotografia como ferramenta potente de registro de suas vivências na escola.

A pesquisa será conduzida pela doutoranda Elise Helene Moutinho Bernardo de Moraes (elisedemoraes@gmail.com | tel. (21) 99675-0033), do Programa de Pós-Graduação do Departamento de Educação (PPGE) da PUC-Rio, sob a orientação da Prof. ${ }^{a}$ Rosália Duarte (rosalia@puc-rio.br | (21) 3527-1815).

Este termo de consentimento está fundamentado na garantia de que a criança será respeitada em todos os sentidos, com destaque para os seguintes aspectos:

a) Seu nome não será divulgado. Todas as informações individuais têm caráter confidencial e, portanto, a apresentação da pesquisa em congressos e artigos científicos se valerá do uso de codinomes, de modo a não permitir a identificação individual dos (as) participantes.

b) A eventual tomada de audiogravação é parte do processo de registros e ocorrerá com seu consentimento, não sendo permitida sua divulgação pública.

c) Todas as atividades previstas pela pesquisa ocorrerão em datas e horários previamente combinados com a gestão da escola, de modo que as atividades e a rotina das turmas não sejam prejudicadas.

d) A pesquisadora está obrigada a prestar esclarecimentos sobre o processo de pesquisa, os fins atribuídos às entrevistas a qualquer momento e sobre os resultados produzidos, na ocasião do término da pesquisa.

e) Se houver qualquer dúvida a respeito dos procedimentos que serão utilizados, os participantes receberão explicações, embora tenham total liberdade para questionar, ou mesmo se retirar desta pesquisa, sem sofrer qualquer tipo de constrangimento por tal decisão.

Os participantes da pesquisa não serão submetidos a riscos físicos ou morais, e terão sua privacidade assegurada. Os procedimentos adotados obedecem aos Critérios da Ética em Pesquisa com Seres Humanos, conforme as diretrizes estabelecidas pelo Conselho Nacional 
de Saúde na Resolução de ${ }^{\circ} 510$ de 07 de abril de 2016. Qualquer queixa ou reclamação referente ao aspecto ético da pesquisa poderá ser feita junto ao Comitê de Ética em Pesquisa da PUC-Rio, localizado à Rua Marques de São Vicente, 225, 2º andar, no Prédio Kennedy - Gávea, Rio de Janeiro, pelo telefone (21) 3527-1618.

Ao participar dessa pesquisa, o participante não terá nenhum beneficio direto. No entanto, esperamos que essa investigação contribua com uma melhor compreensão e aprofundamento sobre a temática e amplie possibilidades às práticas pedagógicas com o uso da fotografia. Esperamos, também, que as reflexões obtidas no decorrer da pesquisa tragam benefícios indiretos às crianças e à escola como um todo, pois os profissionais envolvidos poderão refletir e ressignificar sua prática cotidiana.

Pelo presente documento apresentado em duas vias, em que você declara ter conhecimento dos objetivos e da metodologia que será adotada na pesquisa, você autoriza a participação da criança pela qual é responsável neste estudo, e uma das vias também assinada pela pesquisadora lhe será entregue.

Erechim-RS, de de 2019

Elise Helene M. B. de Moraes

(doutoranda do PPGE da PUC-Rio)

Rosália Duarte

(Orientadora e professora da PPGE da PUC-Rio)

Assinatura do(a) Responsável

Dados da Criança/ Participante:

Nome:

Idade: 


\section{Apêndice C - Termo de Consentimento Livre e Esclarecido | Educadoras}

\section{TERMO DE CONSENTIMENTO LIVRE E ESCLARECIDO}

Você está sendo convidada a participar da pesquisa intitulada "FOTOGRAFIA E DOCUMENTAÇÃO PEDAGÓGICA: DESCREVER, NARRAR E DAR SENTIDO ÀS APRENDIZAGENS EDUCAÇÃO INFANTIL", cujo objetivo é descrever, analisar e compreender o papel que pode ser desempenhado pela fotografia na produção de documentação pedagógica na educação infantil. A finalidade deste trabalho é contribuir para a expansão das reflexões e/ou ações nesta área do conhecimento, em defesa de uma prática pedagógica focada na criança e em suas especificidades, tendo a fotografia como ferramenta potente de registro de suas vivências na escola.

A pesquisa será conduzida pela doutoranda Elise Helene Moutinho Bernardo de Moraes (elisedemoraes@gmail.com | tel. (21) 99675-0033), do Programa de Pós-Graduação do Departamento de Educação (PPGE) da PUC-Rio, sob a orientação da Prof. ${ }^{\text {a }}$ Rosália Duarte (rosalia@ puc-rio.br| (21) 3527-1815).

Este termo de consentimento está fundamentado na garantia de que você será respeitada em todos os sentidos, com destaque para os seguintes aspectos:

a) Todas as informações individuais têm caráter confidencial e, portanto, a apresentação da pesquisa em congressos e artigos científicos só se valerá do uso de seu nome mediante seu consentimento, de modo a não permitir a identificação individual dos (as) participantes que não desejarem.

b) A eventual tomada de audiogravação é parte do processo de registros e ocorrerá com seu consentimento, não sendo permitida sua divulgação pública.

c) Todas as atividades previstas pela pesquisa ocorrerão em datas e horários previamente combinados com a gestão da escola, de modo que as atividades e a rotina das turmas não sejam prejudicadas.

d) A pesquisadora está obrigada a prestar esclarecimentos sobre o processo de pesquisa, os fins atribuídos às entrevistas a qualquer momento e sobre os resultados produzidos, na ocasião do término da pesquisa.

e) Se houver qualquer dúvida a respeito dos procedimentos que serão utilizados, os participantes receberão explicações, embora tenham total liberdade para questionar, ou mesmo se retirar desta pesquisa, sem sofrer qualquer tipo de constrangimento por tal decisão.

Os participantes da pesquisa não serão submetidos a riscos físicos ou morais, e terão sua privacidade assegurada. Os procedimentos adotados obedecem aos Critérios da Ética em Pesquisa com Seres Humanos, conforme as diretrizes estabelecidas pelo Conselho Nacional 
de Saúde na Resolução de n ${ }^{\circ} 510$ de 07 de abril de 2016. Qualquer queixa ou reclamação referente ao aspecto ético da pesquisa poderá ser feita junto ao Comitê de Ética em Pesquisa da PUC-Rio, localizado à Rua Marques de São Vicente, 225, $2^{\circ}$ andar, no Prédio Kennedy - Gávea, Rio de Janeiro, pelo telefone (21) 3527-1618.

Ao participar dessa pesquisa, o participante não terá nenhum beneficio direto. No entanto, esperamos que essa investigação contribua com uma melhor compreensão e aprofundamento sobre a temática e amplie possibilidades às práticas pedagógicas com o uso da fotografia. Esperamos, também, que as reflexões obtidas no decorrer da pesquisa tragam benefícios indiretos às crianças e à escola como um todo, pois os profissionais envolvidos poderão refletir e ressignificar sua prática cotidiana.

Pelo presente documento apresentado em duas vias, em que você declara ter conhecimento dos objetivos e da metodologia que será adotada na pesquisa, você concorda em participar deste estudo, e uma das vias também assinada pela pesquisadora lhe será entregue.

Erechim-RS, de de 2018

Elise Helene M. B. de Moraes

(doutoranda do PPGE da PUC-Rio)

Rosália Duarte

(Orientadora e professora da PPGE da PUC-Rio)

Assinatura do(a) Participante 
Apêndice D - Árvore de códigos e dimensões de análise | ATLAS.ti

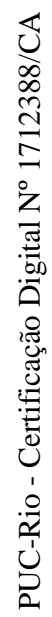

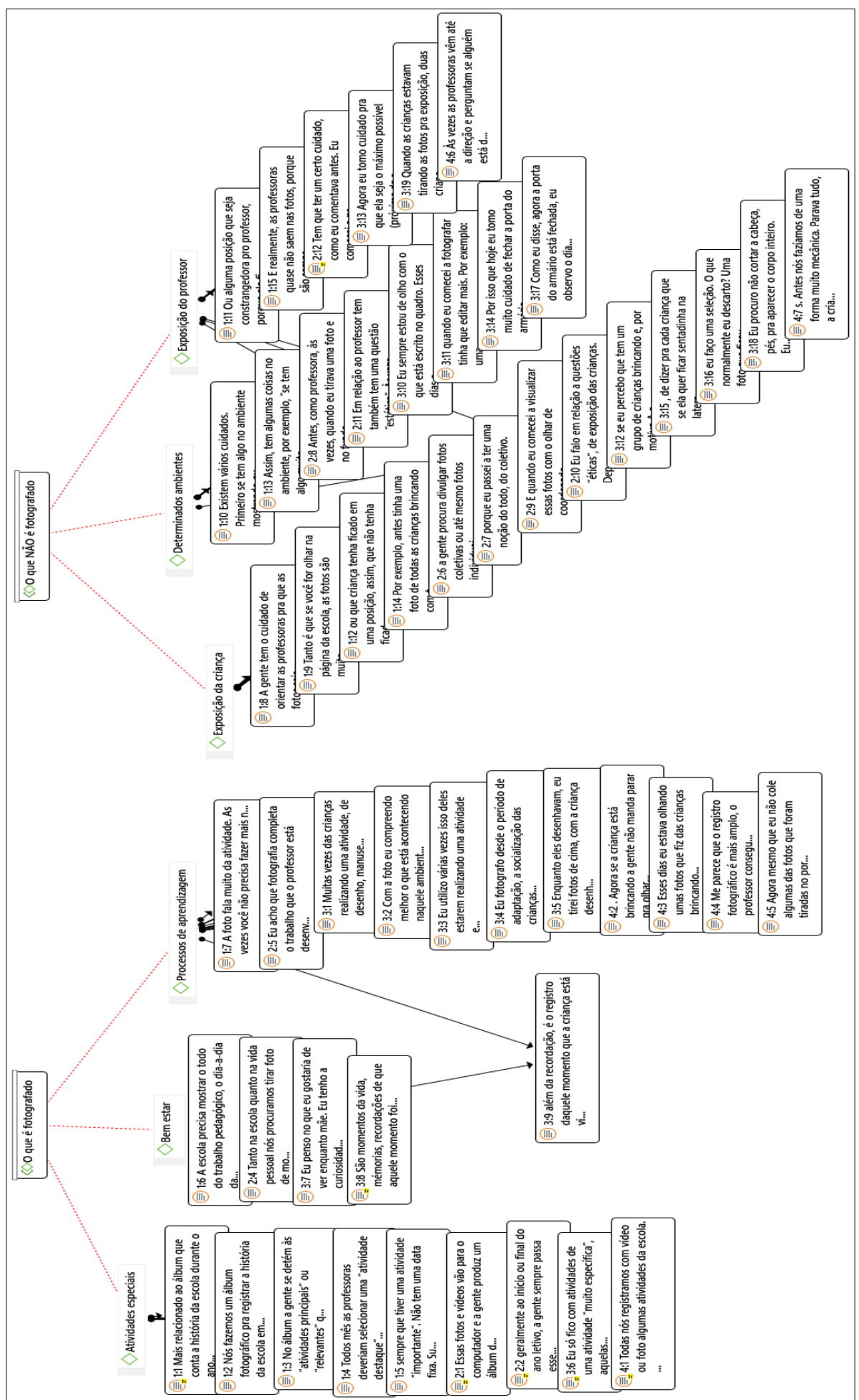


Apêndice E - Nuvem de palavras | Dimensão de análise: "Momentos privilegiados"

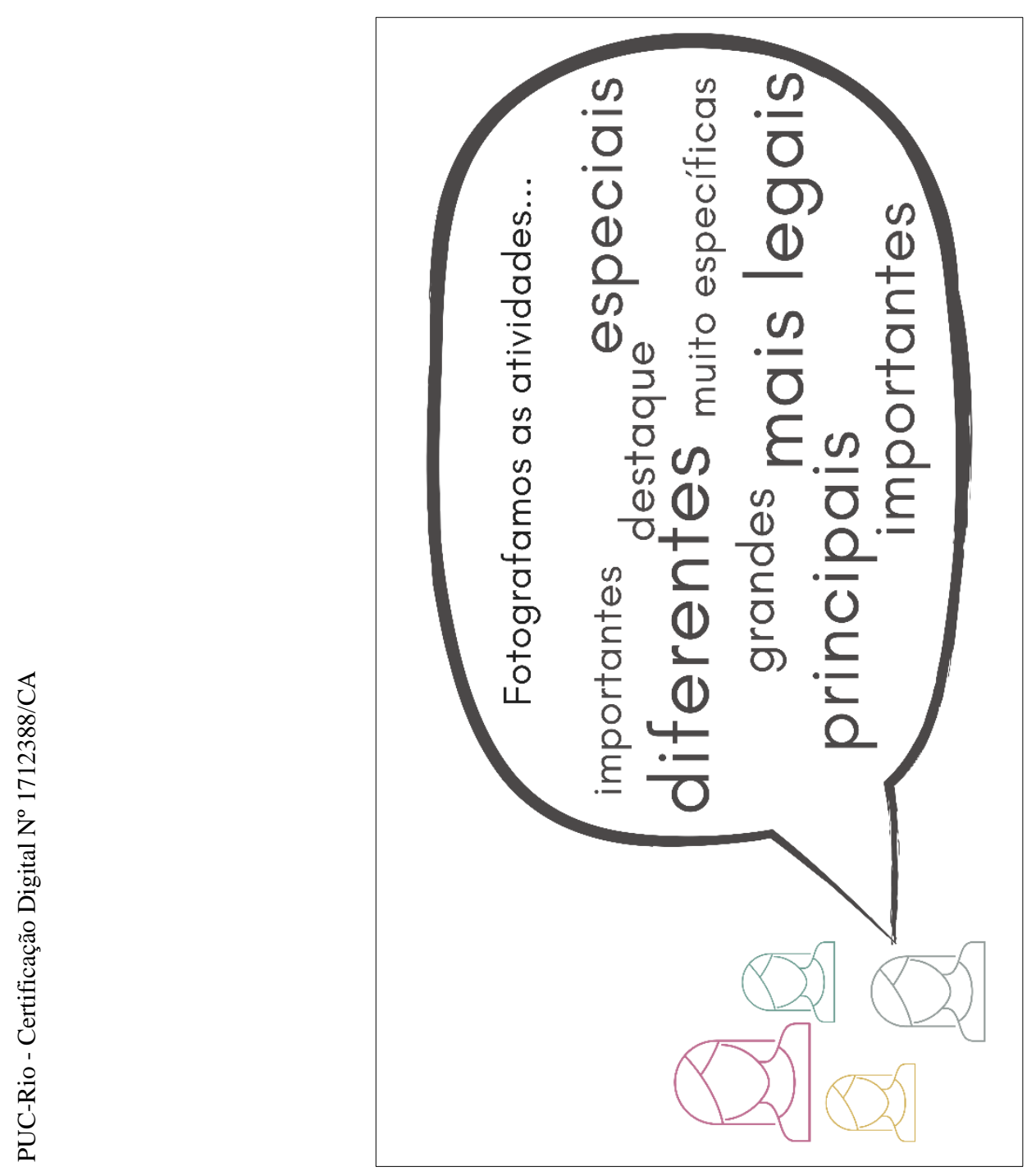




\section{Apêndice F - Revisão de literatura (2018) | Dissertações brasileiras}

\begin{tabular}{|c|c|c|c|}
\hline Ano & Quantidade & Tínlo & Autoria \\
\hline 2009 & 1 & $\begin{array}{c}\text { Organizaçáo do trabalho } \\
\text { pedagogico de professoras da } \\
\text { educaçâo infantil: evidências no5 } \\
\text { registros escritos }\end{array}$ & $\begin{array}{l}\text { MACHADO, Ilze Maria C. } \\
\text { (FEUSP) }\end{array}$ \\
\hline 2011 & 1 & $\begin{array}{l}\text { A documentação na abordagem de } \\
\text { Reggio Emilia para a Educação } \\
\text { Infantil e suas contribuiçóos para as } \\
\text { práticas pedagógicas: um olhar e as } \\
\text { possibilidades em um contexto } \\
\text { brasileiro }\end{array}$ & $\begin{array}{l}\text { BARACHO, Nayara Vicari. } \\
\text { (FEUSP) }\end{array}$ \\
\hline & \multirow[b]{2}{*}{2} & $\begin{array}{l}\text { A formaçâo de professoras em uma } \\
\text { creche universitánia: o papel da } \\
\text { documentação no processo } \\
\text { formativo }\end{array}$ & $\begin{array}{l}\text { VIEIRA, Flaviana Rodrigues. } \\
\text { (FEUSP) }\end{array}$ \\
\hline 2013 & & $\begin{array}{l}\text { "Mas os bebés fazem o qué no } \\
\text { berḉrio, heim?" documentando } \\
\text { açốes de comunicação, autonomia e } \\
\text { saber-fazer de criancas de } 6 \text { a } 14 \\
\text { meses em um contexto de vida } \\
\text { coletiva }\end{array}$ & $\begin{array}{l}\text { FOCHI, Paulo Sérgio. } \\
\text { (UFRGS) }\end{array}$ \\
\hline & \multirow{3}{*}{3} & $\begin{array}{l}\text { A documentaçăo pedagógica e o } \\
\text { trabalho com bebês: estudo de caso } \\
\text { em uma creche universitária }\end{array}$ & $\begin{array}{l}\text { LICHY, Julians Guerreiro. } \\
\text { (FEUSP) }\end{array}$ \\
\hline 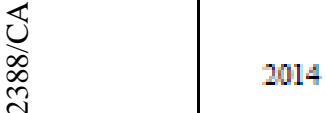 & & $\begin{array}{l}\text { Registros e avaliaçăo na educaçáo } \\
\text { infantil: entrecruzando olhares para } \\
\text { qualificar as práticas }\end{array}$ & $\begin{array}{c}\text { AMARAL, Maria Cristina F. } \\
\text { (UFJF) }\end{array}$ \\
\hline 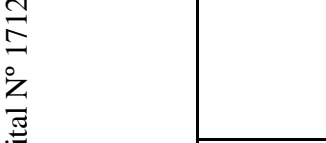 & & $\begin{array}{l}\text { A pratica do registro da rotina de } \\
\text { uma turma de Educaçâo Infantil e } \\
\text { o5 sentidos e significados attriburidos } \\
\text { pelas crianças e sua professora }\end{array}$ & $\begin{array}{l}\text { MEDRADO, Juliana Basilio. } \\
\text { (UFMG) }\end{array}$ \\
\hline 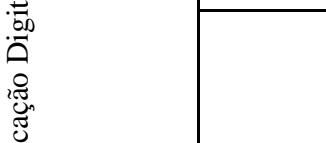 & \multirow{3}{*}{3} & $\begin{array}{l}\text { Avaliaçáo na educaçáo infantil: a } \\
\text { documentaçấo pedagógica e as } \\
\text { práticas docentes no contexto dos } \\
\text { direitos das crianças }\end{array}$ & $\begin{array}{l}\text { MORERA, Juliana Corrêa. } \\
\text { (UFSM) }\end{array}$ \\
\hline 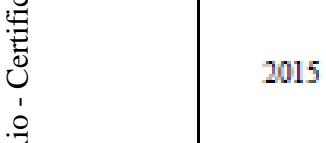 & & $\begin{array}{l}\text { O registro como instrumento de } \\
\text { reflexão na formação do docente: } \\
\text { pesquisa-intervenção em escola } \\
\text { municipal de educação infantil }\end{array}$ & $\begin{array}{l}\text { MERLI, Angélica de A. } \\
\text { (UNINOVE) }\end{array}$ \\
\hline 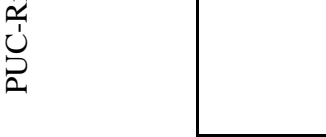 & & $\begin{array}{l}\text { Registros professorais na primeira } \\
\text { infancia: a escrith, as imagens e a } \\
\text { oralidade comso dispositivos de } \\
\text { subjecivação e reflexividade }\end{array}$ & $\begin{array}{l}\text { FERRARESI, Elaine. } \\
\text { (UNISAL) }\end{array}$ \\
\hline & \multirow{3}{*}{3} & $\begin{array}{l}\text { A documentaçâo pedagógica como } \\
\text { mediação à construção do } \\
\text { conhecimento escolar na Educação } \\
\text { Infantil em Manaus }\end{array}$ & $\begin{array}{l}\text { KAWADA, Valdejane T. } \\
\text { (UFAM) }\end{array}$ \\
\hline 2016 & & $\begin{array}{c}\text { Uma experiência de formaçấ } \\
\text { continuada: o papel do coordenador } \\
\text { pedagógico e do registro reflexivo } \\
\text { na formação de professores de } \\
\text { Educação Infantil }\end{array}$ & $\begin{array}{l}\text { BARTHOLOMEU, Fabiana. } \\
\text { (PUC-SP) }\end{array}$ \\
\hline & & $\begin{array}{l}\text { Planejamento, registro e avaliaçáo: } \\
\text { instrumentos que ressignificam a } \\
\text { prática docente na Educação } \\
\text { Infantil. }\end{array}$ & $\begin{array}{l}\text { RAMOS, Rafaela de Morais. } \\
\text { (UFG) }\end{array}$ \\
\hline
\end{tabular}




\section{Apêndice G - Revisão de literatura (2018) | Dissertações brasileiras}

\begin{tabular}{|c|c|c|c|}
\hline Ano & Quantidade & Título & Autoria \\
\hline 2009 & 1 & $\begin{array}{l}\text { A documentação pedagógica } \\
\text { como processo de } \\
\text { investigação e reflexão na } \\
\text { educação infantil }\end{array}$ & $\begin{array}{c}\text { MENDONÇA, Cristina N. de. } \\
\text { (UNESP) }\end{array}$ \\
\hline 2011 & 1 & $\begin{array}{l}\text { A construção de práticas de } \\
\text { registro e documentação no } \\
\text { cotidiano do trabalho } \\
\text { pedagógico da educação } \\
\text { infantil }\end{array}$ & $\begin{array}{l}\text { MARQUES, Amanda } \\
\text { Cristina Teagno Lopes. } \\
\text { (FEUSP) }\end{array}$ \\
\hline 2015 & 1 & $\begin{array}{c}\text { Colecionando pequenos } \\
\text { encantamentos... a } \\
\text { documentação pedagógica } \\
\text { como uma narrativa peculiar } \\
\text { para e com crianças bem } \\
\text { pequenas }\end{array}$ & $\begin{array}{l}\text { SIMIANO, Luciane Pandini. } \\
\text { (UFRGS) }\end{array}$ \\
\hline 2017 & 1 & $\begin{array}{c}\text { Documentação pedagógica: a } \\
\text { produção da criança } \\
\text { protagonista e do professor } \\
\text { designer } \\
\end{array}$ & $\begin{array}{l}\text { HORN, Claudia Inês. } \\
\text { (UNISINOS) }\end{array}$ \\
\hline
\end{tabular}


Apêndice H - Teses e dissertações sobre documentação pedagógica (2018)

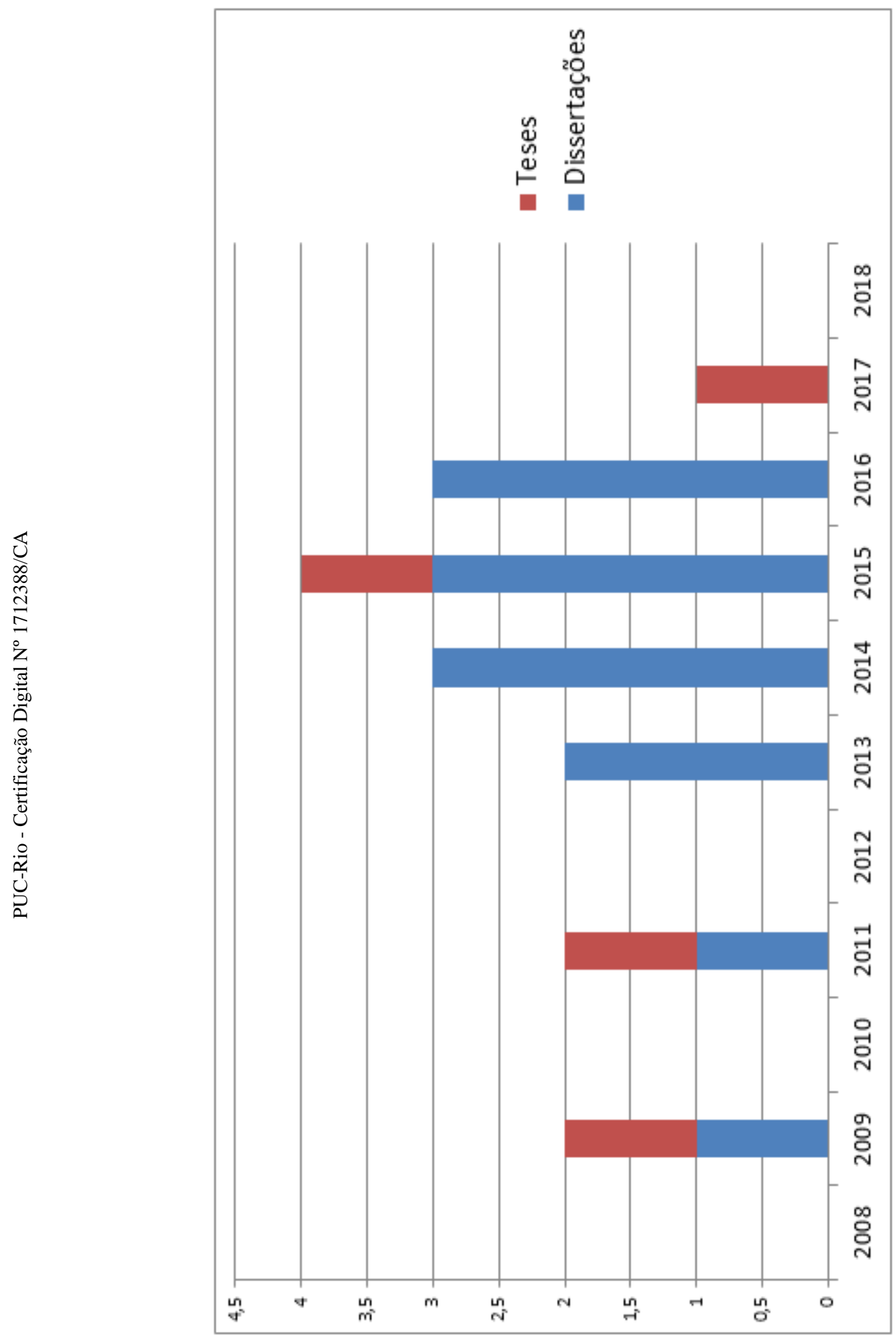


Apêndice I - Revisão de literatura (2020) | Pesquisas Centro de Investigação em Estudos da Criança (CIEC) । Repositorium Universidade do Minho

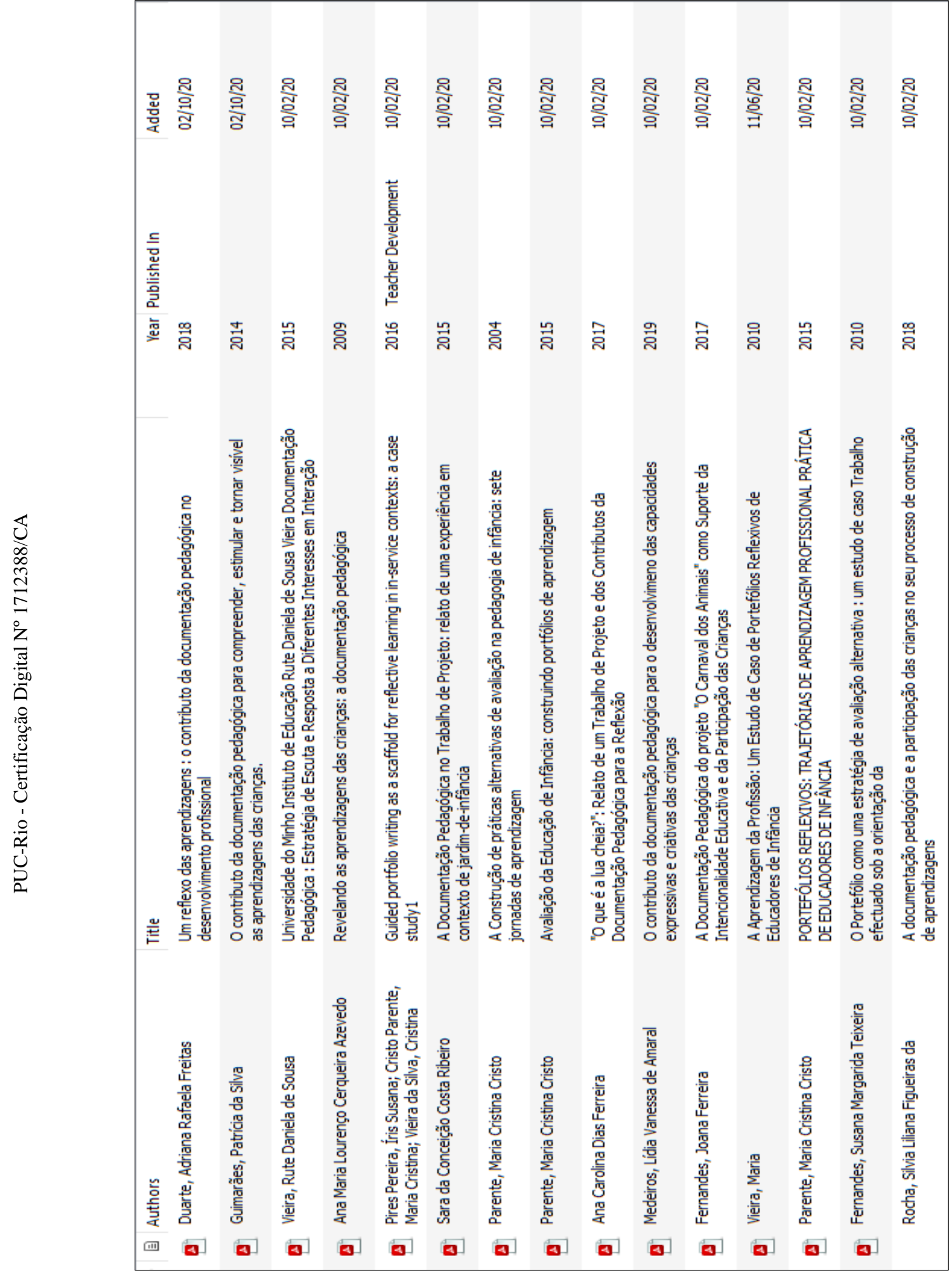




\section{Apêndice J - Revisão de literatura (2020) | Pesquisas estrangeiras Repositórios: b-ON; OpenAIRE}
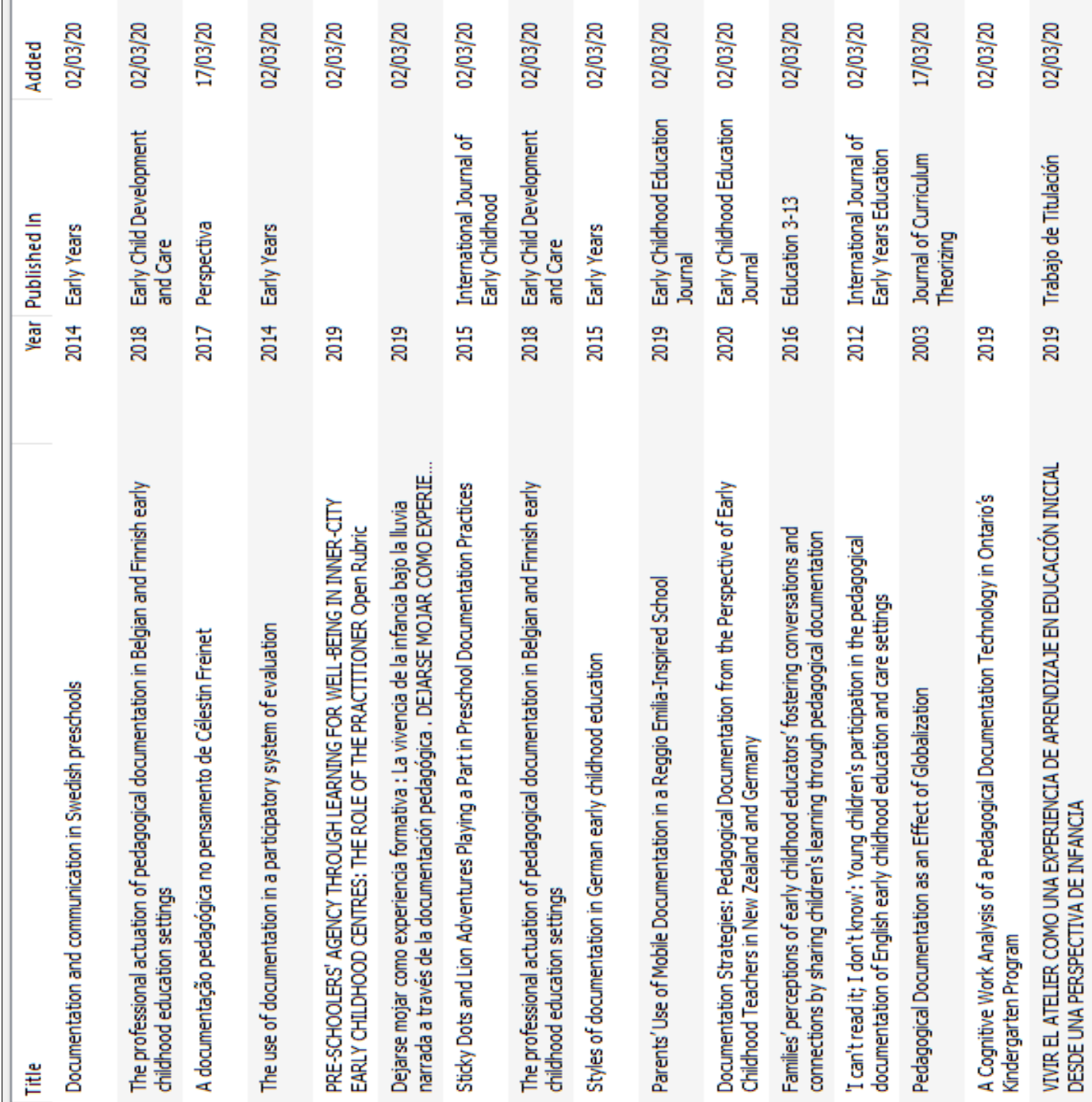

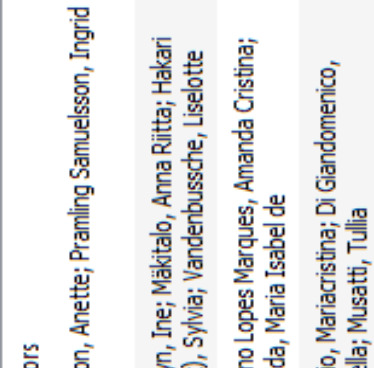
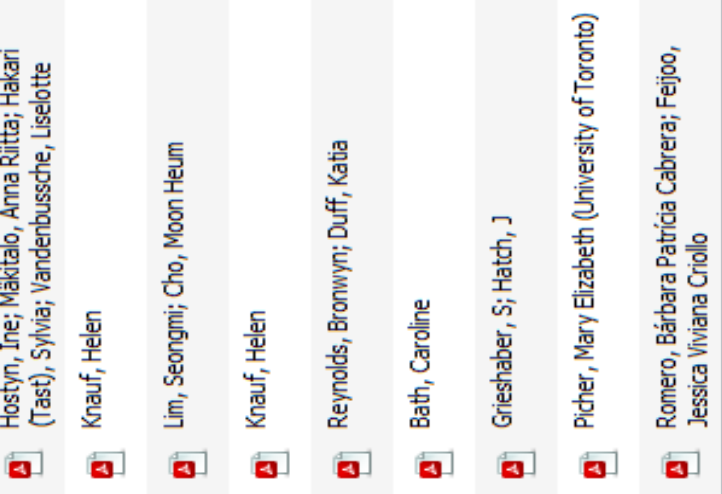


\section{Apêndice K - Caracterização dos grupos}

\begin{tabular}{|c|c|}
\hline Identificação & Especificidades \\
\hline \multirow{6}{*}{ Verde } & - Apenas 4 crianças do grupo já estudavam na escola no ano anterior. \\
\hline & $\begin{array}{l}\text { - Fluxo intenso de entrada e saída de crianças. As famílias têm } \\
\text { preferência pelo turno da tarde, então matriculam as crianças no turno } \\
\text { da manhã e, conforme surge vaga, transferem para tarde. }\end{array}$ \\
\hline & $\begin{array}{l}\text { - As crianças aplaudiam a chamada e as atividades que a professora } \\
\text { sugeria. }\end{array}$ \\
\hline & Não faziam fila para ir ao parque e ao refeitório. \\
\hline & $\begin{array}{l}\text { - Os momentos de atividades e brincadeiras em sala, costumavam ser } \\
\text { calmos e silenciosos. }\end{array}$ \\
\hline & $\begin{array}{l}\text { - As crianças paravam o que estavam fazendo para posar para fotos da } \\
\text { professora. }\end{array}$ \\
\hline \multirow{5}{*}{ Rosa } & O grupo recebeu a pesquisadora com muito afeto. \\
\hline & $\begin{array}{l}\text { - Ingresso de uma criança nova na escola - cega e com suspeita de } \\
\text { surdez/paralisia cerebral. }\end{array}$ \\
\hline & $\begin{array}{l}\text { - As crianças pedem muito à professora para brincarem no parque } \\
\text { externo. }\end{array}$ \\
\hline & - Várias atividades ocorrem em círculo, no chão. \\
\hline & Grupo entrosado e questionador. \\
\hline \multirow{4}{*}{ Azul } & $\begin{array}{l}\text { - No grupo havia uma criança com deficiência motora/paralisia } \\
\text { cerebral, que vinha sendo acompanhado pelo serviço de AEE da } \\
\text { escola. }\end{array}$ \\
\hline & $\begin{array}{l}\text { - As duas professoras do grupo dividem de forma equivalente todas as } \\
\text { tarefas, tanto os cuidados com a criança deficiente quanto a condução } \\
\text { das demais atividades do grupo. }\end{array}$ \\
\hline & $\begin{array}{l}\text { - As crianças do grupo gostam muito de cantigas de roda e } \\
\text { brincadeiras que envolvam o grupo todo. }\end{array}$ \\
\hline & - As professoras revezam a tarefa de fotografar. \\
\hline \multirow{4}{*}{ Amarelo } & - Grupo bastante conflituoso, as crianças discutem muito entre si. \\
\hline & $\begin{array}{l}\text { - A professora constantemente busca alternativas para mediar conflitos } \\
\text { entre as crianças. }\end{array}$ \\
\hline & - Crianças muito questionadoras e curiosas em relação à fotografia. \\
\hline & - Atividades diversificadas para manter o envolvimento das crianças. \\
\hline
\end{tabular}




\section{Apêndice $L$ - Trechos da entrevista com as educadoras (2020)}

Andressa (diretora/2018 | professora/2019) - Na gestão, enquanto equipe diretiva, nós tínhamos uma visão global, acompanhávamos todo o processo, então sabíamos de tudo que estava acontecendo. Quando a pesquisa foi apresentada, foi fácil entender como ela ia acontecer naquele período, porque a gente tinha uma visão total. Foi fácil passar tudo para as professoras em reunião. Lembro do dia em que você mostrou algumas fotos em reunião e mostrou como era a nossa escola também. Era possível ver de uma forma global. Na sala de aula, depois, eu me senti mais ativa no projeto (de intervenção), porque foi um trabalho direto com as crianças. Foi um trabalho focal, na sala. Mas então, eu perdi a visão do todo. Fora dali eu não sabia o que estava acontecendo ou não.

Tchéssika (vice-diretora/2018 | professora/2019) - Eu concordo, quando estávamos na equipe diretiva, era mais fácil ver o que todas as professoras estavam trabalhando e ver de outro ângulo o meu trabalho também, porque eu também estava em sala de aula em um dos turnos. E eu notei que quando nós voltamos para a sala de aula, era possível transformar aquela ideia do teórico em prática. A tentativa era não fazer a foto como antes, não dava mais para fazer uma foto por fazer. Eu comecei a tentar fazer com que a foto fosse algo importante para as crianças e que as próprias crianças fossem parte desse processo.

Franciane (coordenadora/2018 | professora/2019) - Enquanto equipe diretiva, a gente tinha uma visão do todo. A ideia de trabalhar com a fotografia partiu de uma visão que a gente teve em conjunto com as professoras. As professoras já faziam bastante foto, mas ainda dava para melhorar essa forma de registro. Então, nós como parte da equipe diretiva, tínhamos como objetivo primar pela qualidade da educação, das propostas que eram oferecidas às crianças. A ideia era qualificar o registro com fotografia, então a gente passa a trabalhar com a fotografia não mais de modo aleatório. Iniciamos um trabalho mais específico, centrado e com um objetivo maior. E, enquanto professora, eu pude pôr em prática algumas dessas orientações que eu mesma dava como coordenadora. Eu passei a trocar mais ideias com as colegas professoras que trabalhavam com o mesmo nível pra repensar a forma como a fotografia podia ser feita. Complementando a fala da Andressa, antes nós tínhamos uma visão do todo e depois o 


\section{Apêndice M - Trechos da entrevista com as educadoras (2020)}

Franciane (coordenadora/2018 | professora/2019) - Então, eu vou citar alguns aspectos que mudaram na minha prática em relação à fotografia, mesmo que hoje eu já consiga ver que muitas coisas poderiam ter sido diferentes. Consigo ver o quanto nós já fizemos, mas também vejo quanto ainda precisamos melhorar. Eu estou falando, em parte, pelas colegas também, porque nós acompanhávamos o trabalho uma da outra e nos ajudávamos bastante. 1) As fotografias passaram a ter um objetivo maior. "O que eu quero mostrar com essa foto?". $2^{\circ}$ ) As fotos ficaram mais espontâneas. Antes a criança ficava estática, olhando diretamente pra câmera. 3º) Em alguns momentos, as fotos que eu produzi conseguiram mostrar o percurso de uma proposta. Isso eu conseguia juntando duas ou três fotos de uma mesma proposta, mostrando em sequência como foi o momento. (...) $4^{\circ}$ ) Outro aspecto que mudou em relação à fotografia é sobre a estética, principalmente na organização dos espaços. Ou seja, nós começamos a reparar em tudo que estava a nossa volta e escolher melhor os espaços para as atividades. A foto não pode ter bagunça, um monte objetos jogados sem sentido. O ambiente precisa estar organizado pra que se consiga mostrar o momento que a criança está vivendo. 5) A foto como ponto de partida. Muitas vezes nós fazíamos a foto só para mostrar um resultado final, mas ela pode ser o início também. Foi o que nós fizemos com as turmas em relação às "regras e combinados". Nós elaboramos um painel a partir das fotos das crianças e isso foi retomado durante o ano todo. Nesse caso, a foto foi o nosso ponto de partida. $6^{\circ}$ ) Sobre as coletâneas: depois que nós imprimimos as fotos das crianças, nós passamos a pedir para que elas próprias guardassem nas caixas de registros (cada criança possuía sua caixa de atividades). Enquanto as crianças guardavam essas atividades nas caixas, elas passaram a relatar o que lembravam sobre aquele momento representado nas fotos. Foi algo que eu comecei a aplicar de forma mais sistemática.

Andressa (diretora/2018 | professora/2019) - O uso das fotografias também mudou muito na minha prática ao longo da pesquisa. Eu tive bastante experiência como professora até 2015. Depois eu vivi a experiência da gestão, em que eu lidava com as fotos que iam para a página da escola no Facebook, para os pais acompanharem. Foram três anos na gestão. Quando retornei para a sala de aula (em 2019), eu pensei: "Agora eu vou ser outra em relação às fotos". E eu realmente mudei muito. Antes eu tinha o hábito de tirar fotos bem estáticas. As crianças estavam prontas, acabou. Depois, eu passei a observar melhor os momentos. Eu olhava pra uma atividade e pensava. "essa atividade vai fazer sentido fotografar!". Eu também comecei a conversar com as colegas sobre as fotografias e sobre a forma de fotografar. E durante uma atividade, eu passei a fotografar as crianças em momentos diferentes, uma no início, outra 


\section{Anexo A - Declaração de Ciência e Concordância das Instituições envolvidas | PUC-Rio - SMED/Erechim (2018 e 2019)}

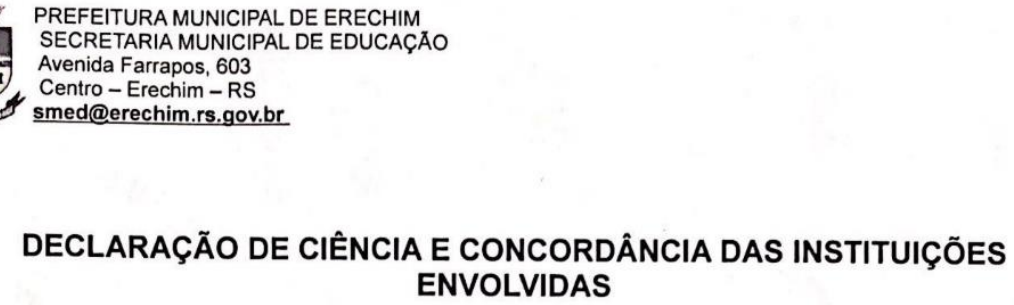

Autoriza-se a acadêmica do Curso de Doutorado em Educação, Elise Helene Moutinho Bernardo de Moraes, para realizar um Projeto de Pesquisa intitulado como "Fotografia como registro e documentação pedagógica: Pesquisaintervenção em uma Escola de Educação Infantil" pela Pontifícia Universidade Católica do Rio de Janeiro, PUC, na EMEI Dom João Aloísio Hoffmann para fins de trabalho de conclusão de curso, nos meses de outubro a dezembro de 2018 e fevereiro a julho de 2019.

Com o objetivo de atender às exigências para obtenção de parecer do Comitê de Ética em Pesquisa envolvendo Seres Humanos, Vanir Clara Bernardi Bombardelli - Secretária Municipal de Educação, a representante legal da instituição Secretaria Municipal de Educação envolvida no projeto da pesquisa, declara estar ciente e de acordo com seu desenvolvimento nos termos propostos, salientando que os pesquisadores deverão cumprir os termos da resolução 466/12 do Conselho Nacional, bem como o Estatuto da Criança e do Adolescente, Lei 8.069/90.

CNBombareh.

Vanir Clara Bernardi Bombardelli - Secretária Municipal de Educação

\section{Glise Holene M. B. de Meraes}

Elise Helene Moutinho Bernardo de Moraes - Pesquisador Responsável

Aliana to Bonanos

Aliana Endler Bonavigo- Coordenadora da Divisão de Educação Infantil 


\section{Anexo B - Declaração de Ciência e Concordância das Instituições envolvidas | PUC-Rio - SMED/Erechim (2020)}

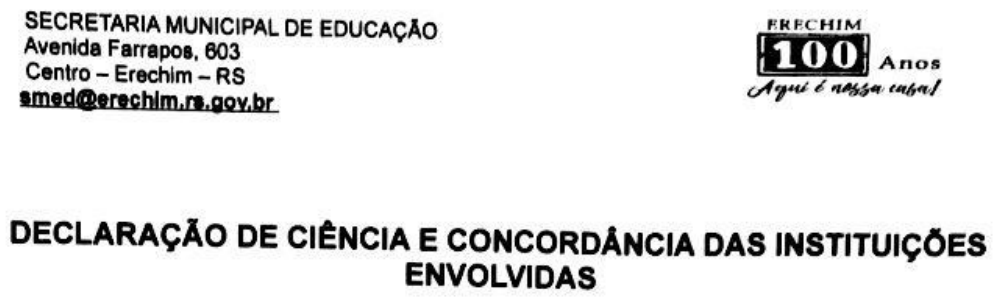

\section{DECLARAÇÃO DE CIÊNCIA E CONCORDÁNCIA DAS INSTITUIÇÓES ENVOLVIDAS}

Autoriza-se a académica do Curso de Doutorado em Educaçăo, Elise Moutinho Bernardo de Moraes, para realizar um Projeto de Pesquisa intitulada como "Fotografia como registro e documentaçăo pedagógica: Pesquisaintervenção em uma Escola de Educação Infantil" pela Pontificia Universidade Católica do Rio de Janeiro, PUC, na EMEI Dom João Aloísio Hoffmann para fins de trabalho de conclusão de curso, no período de março a dezembro de 2020.

Com o objetivo de atender às exigências para obtençăo de parecer do Comitê de Ética em Pesquisa envolvendo Seres Humanos, Vanir Clara Bernardi Bombardelli - Secretária Municipal de Educação, a representante legal da instituição Secretaria Municipal de Educação envolvida no projeto da pesquisa, declara estar ciente e de acordo com seu desenvolvimento nos termos propostos, salientando que os pesquisadores deverão cumprir os termos da resolução 466/12 do Conselho Nacional, bem como o Estatuto da Criança e do Adolescente, Lei $8.069 / 90$.

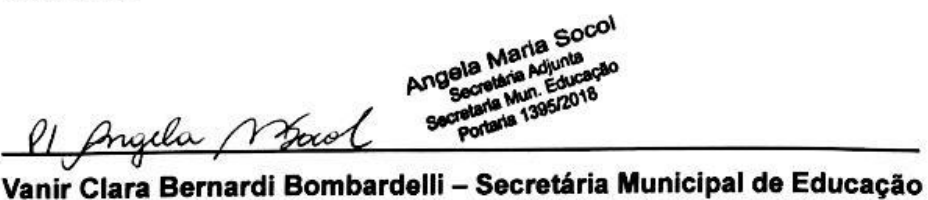

Alioma it. Bonoviog

Aliana Endler Bonavigo- Coortlenadora da Divisão de Educação Infantil

reticado por mariáures Moutinhe Bermando de movar. Elise Moutinho Bernardo de Moraes-Pesquisador Responsável 


\section{Anexo C - Sensibilidade ao design (Original)}

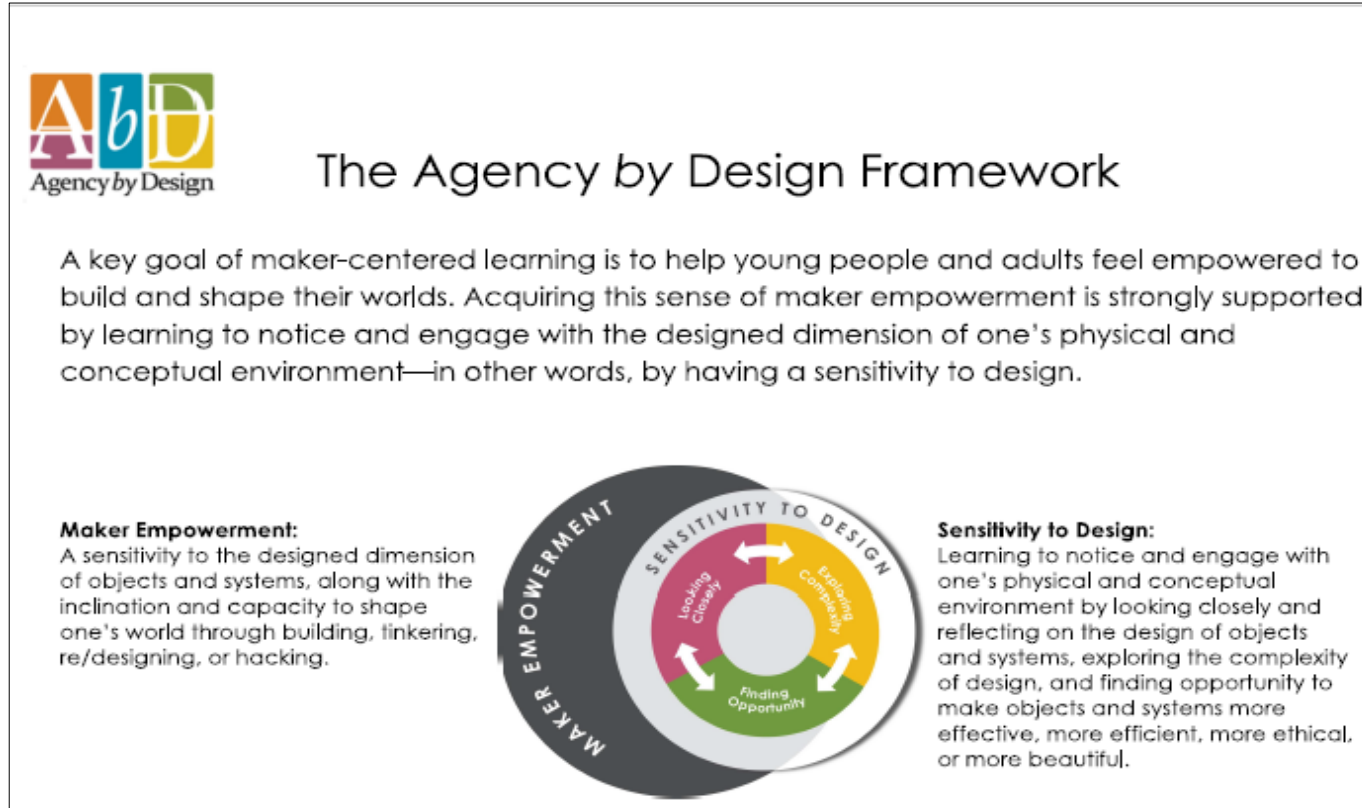

Sensitivity to design develops when young people and adults have opportunities to: look closely and reflect on the design of objects and systems, explore the complexity of design, and understand themselves as designers of their worlds. Accordingly, the Agency by Design framework describes three interrelated capacities that help learners develop a sensitivity to design: Looking Closely, Exploring Complexity, and Finding Opportunity. For each of these capacities, there is a set of observable "moves" - or indicators — that learners and educators can use to help design maker-centered learning experiences, and to support, observe, document, and assess maker-centered learning. They apply to individual as well as collaborative learning.

\footnotetext{
A.b Making Moves

Learning moves that support a sensitivity to design

LOOKING CLOSELY: Using any and all of the senses to examine objects and systems in order to notice their intricacies. nuances, and details. By looking closely, one may begin to see the complexities inherent in objects and systems.

- Notice everything-Cast a wide net to capture all that you can observe.

- Revisit-Look/listen/touch again, and see if you can find something new.

- Use categories-Look for different kinds of features or components.

- Juxtapose-Look at things side by side; compare, observe relationships.

- Physically change perspectives_Look from high, low, far away, close up.
}

EXPLORING COMPLEXITY: Investigating the interactions between the various parts and people associated with objects and systems, including the range of values, motivations, and priorities heid by the individuals who engage with particular objects and systems.

- Explore inner workings-Explore how things, ideas and systems work-what are their parts and interactions?

- Explore points of view -Consider and take different perspectives: What different ways can you look at this?

- Probe your own perspective-Examine your own assumptions and beliefs.

- Look back and forwarc-Explore the histories and possible futures: How did this come to be? Where might it be going

- Tinker to explore-Take things apart, put things together, play around with how things work.

FINDING OPPORTUNITY: Building on close observations and explorations of complexity to see the potential for building, tinkering, re/designing, or hacking objects and systems.

- Envision-Imagine what could be invented, or how things could be changed.

- Reframe-Rethink, refocus, or re-define a problem, opportunity, or procedure; hack or repurpose how things work.

- Source resources-Be proactive and creative about finding information, advice, and instruction.

- Prototype and test-Make models and run tests: try things out to see what works.

- Make (and draw) plans-Identify steps; sketch what things could look like and how they could work; illustrate ideas \& processes.

Fonte: Agency by Design | Project Zero (2020) 
Anexo D - Atributos para qualificação dos espaços públicos

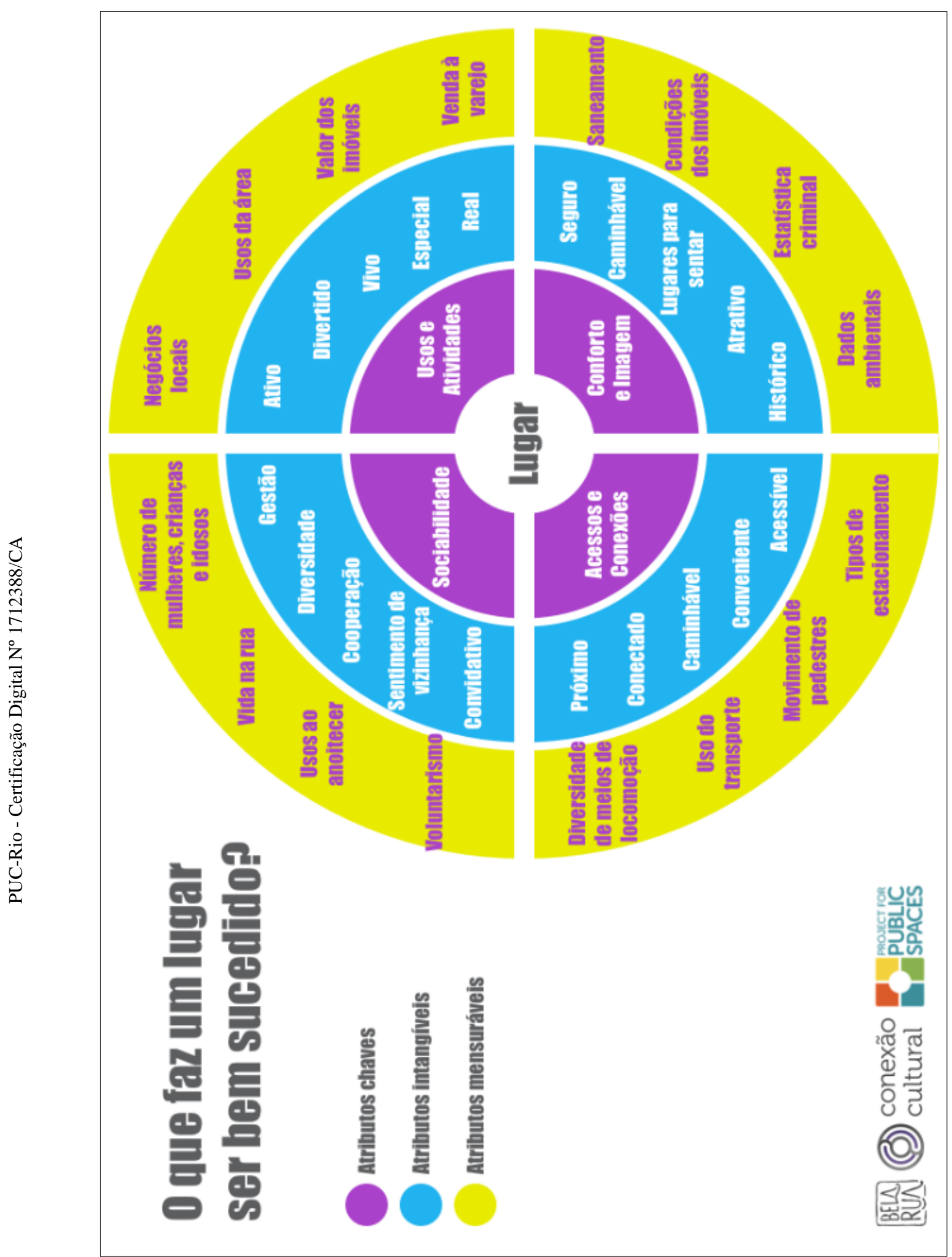

Fonte: Heemman e Caiuby (201-). 